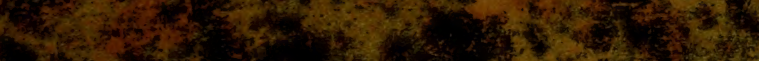

rese (2)

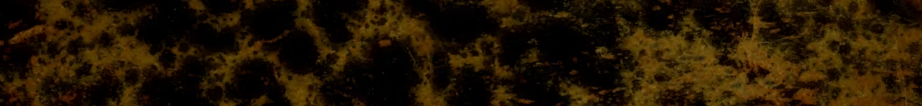

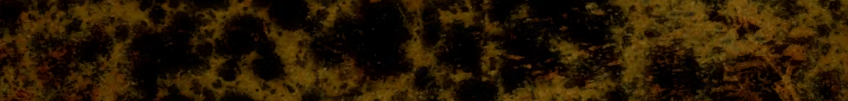

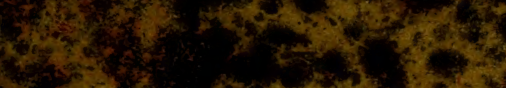

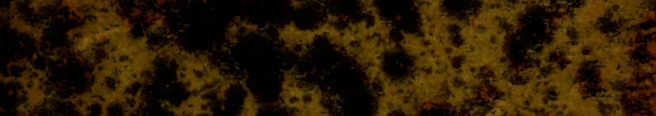

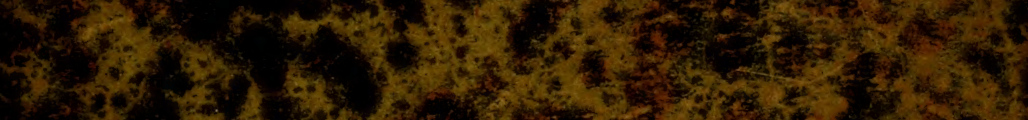

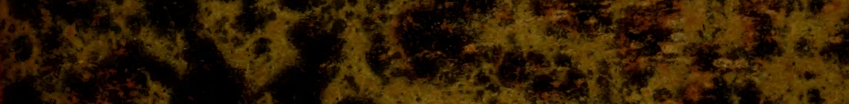
(3) (4)

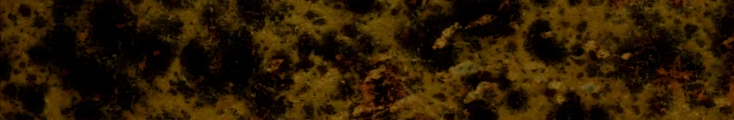
हैi $2 x^{2}, \frac{1}{2}$

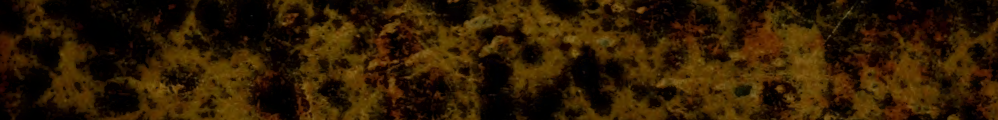

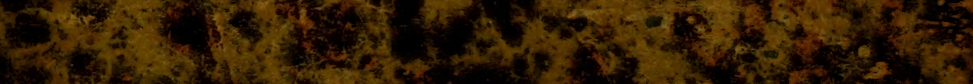

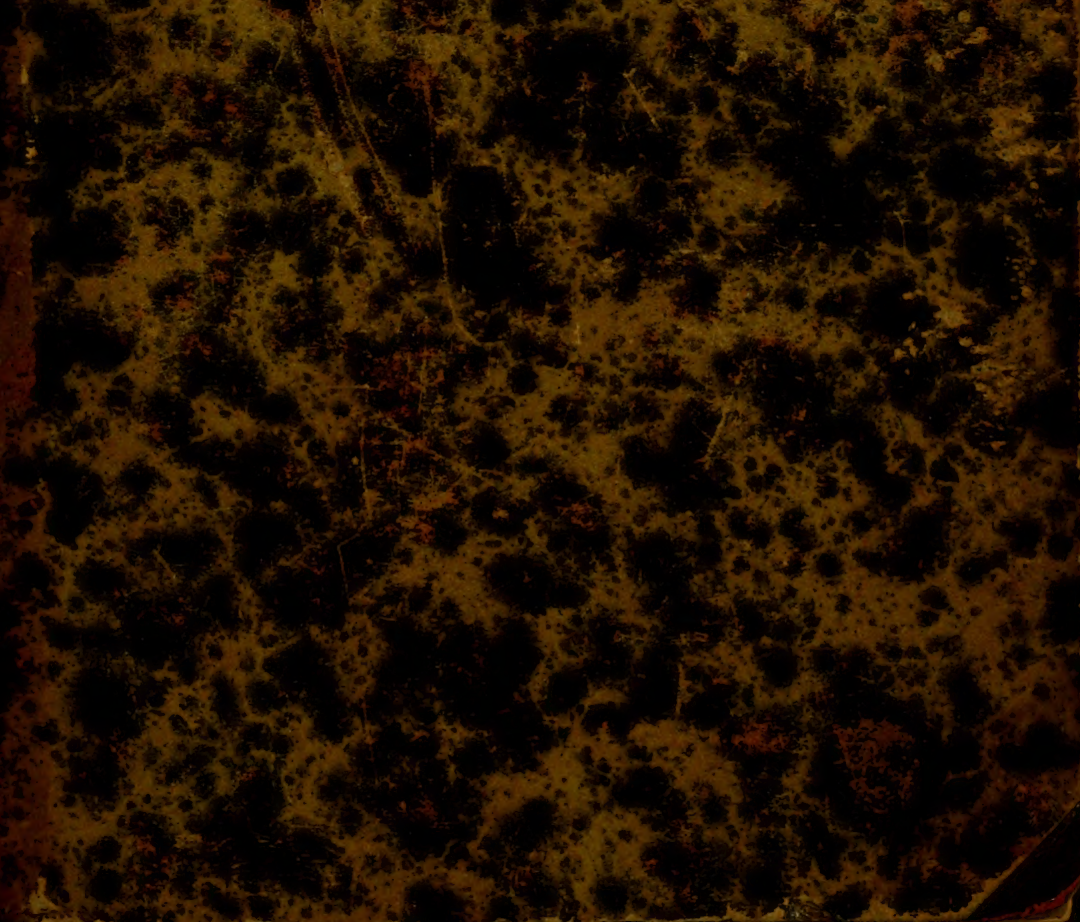


bind-salale -inúcoa

blad-1alad) (hictue/ nowaine if. sudivin-talad chicoréc (C. endivia) bleta-selleni (ajium graveabers ducer) bjora-refua (bot.) calystegia, m. (3) Larrginas (Jolkop. hemisaille, amonsette jeod-6ink, de " Giäd pister gue

lique de mitre Kagel-ventir/jersus.) gelhampo likig bild

garkice?ganes mesper

fran-aimande (rattor.) eviction

(2 dipprsieder ete)

gódsel-vatten (Lanthl.) lisier, lixier, m.

finkel-oga huife de ponme as herre

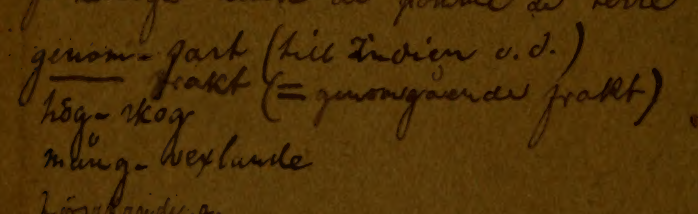
forsularide; a.

uftum aido- makhare

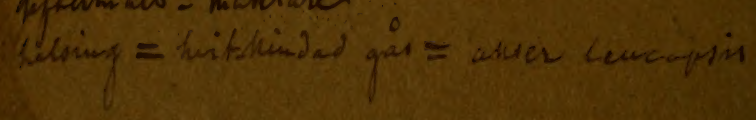




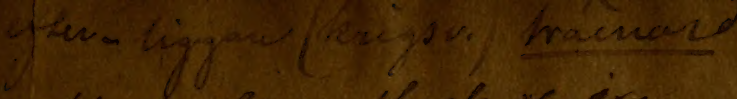
napper de glacu-theet of ice finertan $=$ nyfitew

chryopié quedmakarekont

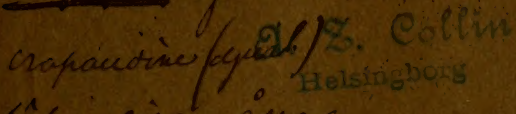
bêfe atine asme=

haly-manformig (60ti) lumule gal-beek Luriberex

- het luridites

ossecets de l'ouic hoinel-bew mad havblowwor (bot.) masculiflore obs. Mrasaye (i Rob.diystén) ould de wes firekommander fermes doffher) (Laite. maffité)

médiastin

houings-doutst méliceris

ber-grotio caverne orsifice

pradiatrie

rampiciniforme (látei)

panners augeryfede

passage des saugles (ojusts) ging jougt 

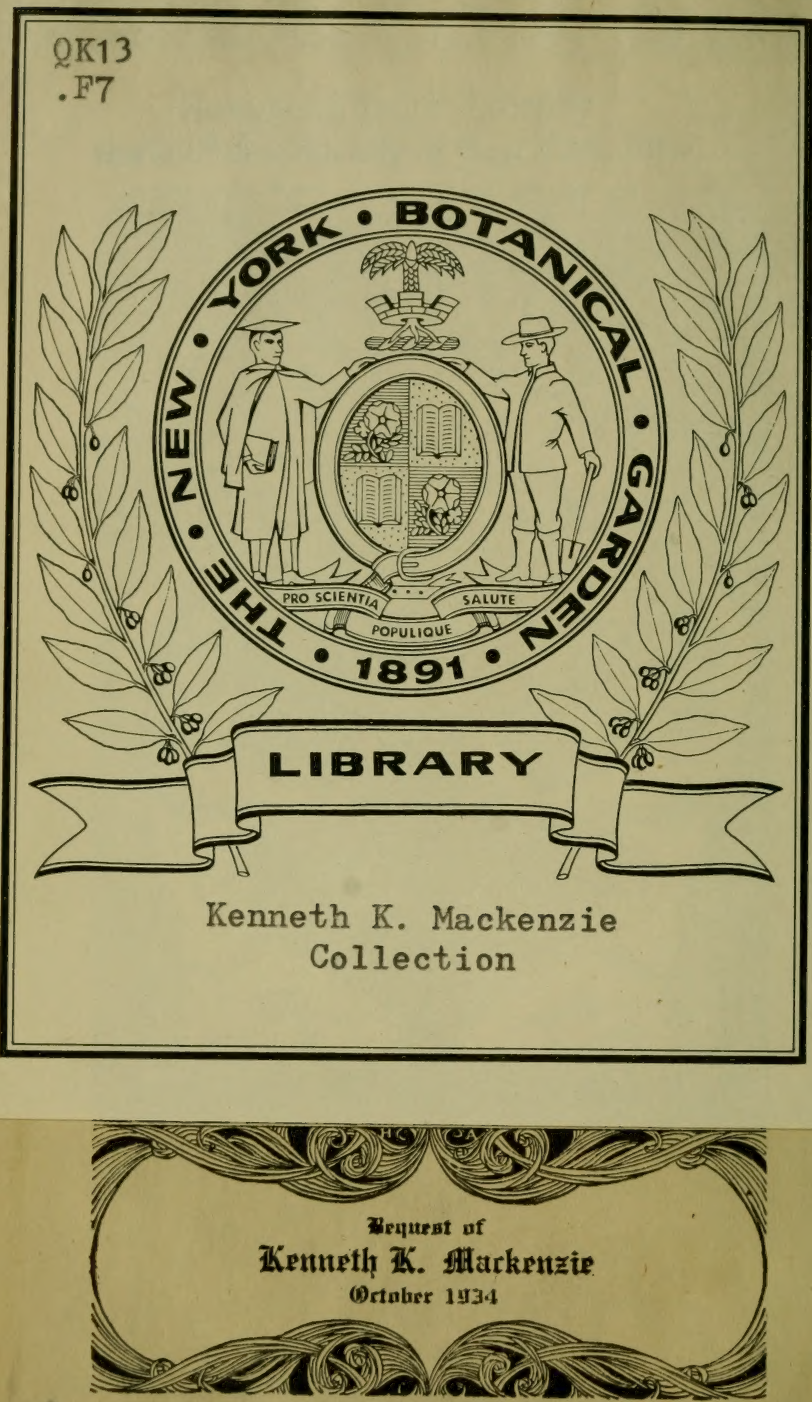


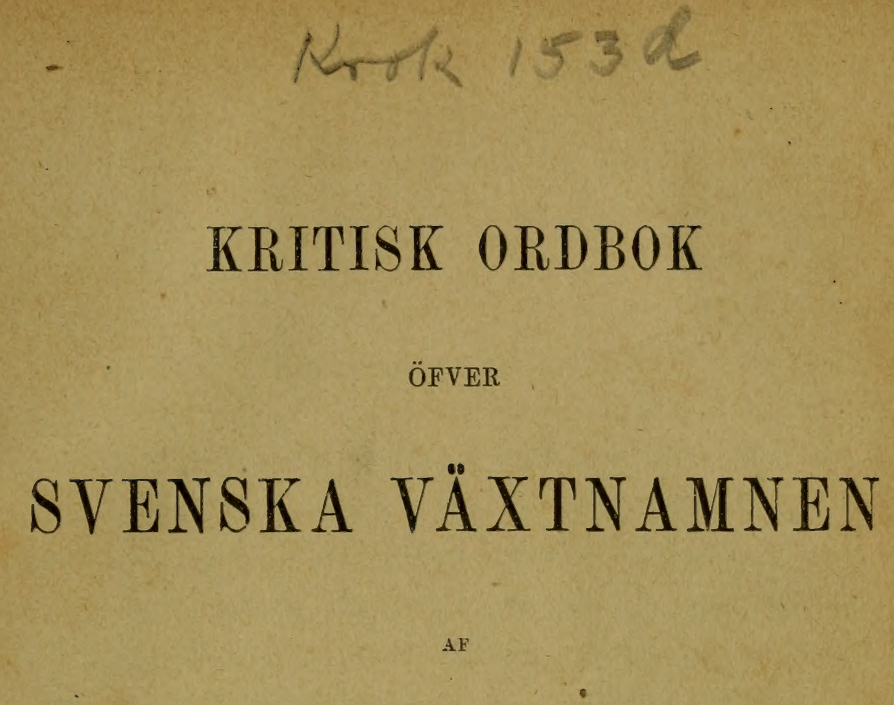

ELIAS FRIES.

UTGIFVEN

AF

SVENSKA AKADEMIEN.

STOCKHOLM, 1880.

KONGL. BOKTRYCKERIET

P. A. XOHSTEDT \& SÖNER. 
QK13

. F7

580.1

7754 


\section{Utgifvarens förord.}

Förevarande arbete, fullbordadt på 1860-talet, var af författaren ämnadt att tjena till ledning vid växtnamnens behandling $\mathrm{i}$ den ordbok öfver modersmålet, hvilken Svenska Akademien då hade för afsigt att utarbeta. De omständigheter, som sedermera föranledt Akademien att inskränka sin verksamhet i sådant syfte, äro angifna $\mathrm{i}$ hennes underdåniga utlătande den 19 november 1872 (tryckt i 48:e delen af Akademiens Handlingar), hvarigenom hon afsade sig det statsanslag, som utgått till befordran af hennes ordboksarbete. Akademien uttalade dervid sin förhoppning »att kunna fortfarande i någon mån medverka till ordboken genom förarbeten, hvilka hon önskade att, så vidt möjligt vore, efter hand göra för allmänḩeten genom tryck tillgängliga, för att sàlunda efter förmåga fullgöra det uppdrag, som blifvit Akademien af hennes höge stiftare lemnadt». Som ett sådant förarbete allmängöres nu denna Ordbok öfver de Svenska växtnamnen. Akademien har härvid ansett sig böra erinra, att författaren, ehuru han öfverlåtit sitt verk till Akademiens fria förfogande, likväl ej åsyftat dess utgifning såsom ett särskildt arbete; han skulle annars otvifvelaktigt hafva egnat det en större omsorg i stilistiskt afseende. Men hvad i sådan måtto kan finnas att anmärka, har synts 
Akademien vara af så föga väsentlig vigt, helst vid ett arbete af denna art, att det ej bort utgöra hinder för dess offentliggörande. Hvad angår de från våra skalder hemtade språkprofven, hvilka, enligt författarens medgifvande (se hans inledning), kunde efter godtfinnande upptagas eller uteslutas i Akademiens tillämnade ordbok, skulle författaren, om han sjelf besörjt sitt arbetes särskilda utgifning, sannolikt hafva utelemnat dem; Akademien har dock ej ansett sig böra vidtaga en sådan åtgärd. Deremot har hon funnit några tillägg erforderliga för att göra arbetet mera begagneligt; dessa äro: de flesta uppgifterna om citatställen ur anförde författare, förteckningen på desse författare, och registret öfver de Latinska växtnamnen med hänvisning till deras Srenska benämningar. 


\section{IN LEDNING.}

$V_{\text {äxternas namn förete otvifvelaktigt den mest obestämda del }}$ af Svenska språket. Utom trädslagen och några få örter, hafva våra fleste växter olika namn $\mathrm{i}$ olika landskap (och ofta flera $\mathrm{i}$ samma landskap); ja, hvad än värre är, samma benämningar föras till helt olika växter*, eller ock äro namnen så i uttalet förbråkade, att man svårligen igenkänner dem. För att utreda, hvilket uttal af ett namn är det rätta eller hvilken växt namnet rätteligen tillkommer, måste man följa dessa ords utbildning från äldsta tider, söka utforska deras härledning och det begrepp, folket fäster vid dem, och tillika deras användande i de öfriga Germaniska språken. I senare fallet finner man ofta en förvânande öfverensstämmelse, icke blott $\mathrm{i}$ de gamla gemensamma stamorden, utan äfven $i$ en del yngre, skenbart tillfälliga benämningar. Växtnamnen blifva derigenom af stort interesse i lingvistiskt hänseende, och bland våra Svenska finna vi bevarade många fornnordiska ord, som i nuvarande språket utgått. Dessa

* Bland otaliga exempel härpå må nämnas, att, enligt Linnés Skåńska resa, s. 238, i en trakt af Skåne Spircea Filipendula kallades Konvalje för luktens skull, ehuru dessa båda växter ej ega minsta likhet, och i Upland öfverföres namnet Konvalje till Pyrola rotundifolia. 
böra, i min tanke, bevaras som dyrbara antiqviteter. Anmärkningsvärdt är, att A. F. Dalin och andre ordboksförfattare, som eljest npptaga de obetydligaste växtnamn, förkasta just de fornåldriga namnen, emedan dessa genom nuvarande sprâkbruk ej kunna tydas".

Vi ega betydliga samlingar af Svenska växtnamn redan före Linné, nemligen genom Franckenius (1638), Tillandz (1683), Bromelius (1694) och Linder (1716). Men de af dem anförda namnen äro till stor del antingen öfversättningar från de Grekiska och Latinska, som utgå från en helt annan naturåskådning, eller ock lånade ur främmande tungomål, hvilka namn, då de icke ingått i allmänna språkbruket, ej förtjena upptagas i en Svensk ordbok *. Det samma gäller om en del genom Tyska kräuterbücher införda namn, som väl af åtskillige kompilatorer blifvit brukade, men icke ingått $\mathrm{i}$ folkspråket och nu synas vara utdöda, t. ex. Affodil, Andorn, Gamander, Gundelref, Poleja, Sempertin, Tusengyllenkrut, Tusendygdegräs m. fl. Samma öde förtjena vissa andra från Tyskan införda, men löjligt förbråkade namn, såsom Leffelkrut af Lóffelkraut, Fulbom af Faulbaum, Spelbom af Spillbaum. Det är i synnerhet på Gotland som dessa träffas.

Under sina resor upptecknade Linné noggrant växternas namn i folkspråket, och han erhöll af sina lärjungar rikliga uppgifter från alla landskap. Rikaste och pålitligaste källan för dessa

* Undantag från ett sådant förfarande gör Rietz i sin Ordbok öfver Svenska allmogespråket.

** De bland dessa, som af Wahlenberg blifvit àterupptagna, kunna dock icke förbigås. 
namn är derföre Linnés Flora Svecica. Åtskilliga bidrag hafva visserligen sedermera lemnats af Retzius m. fl., men i allmänhet mindre vigtiga. Det är en verklig förlust, att Linné ej faststälde Svenska namn på samtliga våra högre växter, såsom han gjorde i afseende på gräsen. Liljeblad sökte fylla denna brist, men upptog, i stället för att använda det i folkspråket bevarade rika ordförråd, vanligen de Latinska namnen, dock i flera fall så förbråkade, att man svårligen kan igenkänna dem, t. ex. Byll af Bupleurum, Kara af Chara, Lysing af Lysimachia, Lyst af Lychnis, Näfta af Nepeta, Ofris af Ophrys, Orbe af Orobus, Osmund af Osmunda, Rym af Erysimum, Sirse af Circæa, Sist af Cistus, jemte många flera af likartadt slag. Billberg i Svensk Botanik dref denna rigtning till karrikatur. Han ville förkasta alla Svenska namn och införa de Latinska med stympadt uttal; sâ kallar han t. ex. Hafre för Avén, Smultron för Fragar, Säf för Scirp.

Att erhålla allmänt antagna och faststälda Svenska växtnamn är i närvarande tid ett nödvändigt behof. Man har hittills hjelpt sig med de Latinska, men sedan nu speciell botanik läres i real-, land́tbruks-, ja folkskolor, äro Svenska namn oundgängliga. För dessas erhållande har det varit af största vigt att egna synnerlig uppmärksamhet åt folkspråket. Utom det att jag sjelf insamlat 'och genom vänner bekommit talrika bidrag, har jag noga jemfört det ymniga förråd, som förut i tryck meddelats. Men dessa växtnamn fordra en noggrann kritisk granskning. Mânga bland dem bero på ett misstag dels af namngifvaren, dels af upptecknaren. Flera äro så obetydliga, tillfälliga, ja blott skämtvis gifna (t. ex. Pelle på strand, Lasse på tomten), att de ingen uppmärksamhet 
förtjena, hvarpâ Tŕröningssvärds förteckning öfver växtnamnen i Dalarne lemnar talrika exempel. Upptecknandet af folksprâkets namn är icke en sâ lätt sak som man skulle förmoda. I allmänhet tycker jag mig finna hos ordboksförfattare en hunger efter mainga namn; mig synas färre och godkända ega företräde. I en ordbok öfver landskapsmâlen mâste man söka uppsamla alla vexlingar i uttal; men i en ordbok öfver rikssprâket bör man väl hemöda sig att âterföra dessa till rikssprâkets uttal.

Så länge likväl de fleste vilja framhålla sin hembygds benämningar eller, hvad ännu sämre är, af subjektift estetiskt tycke föredraga mera klingande namn och förkasta dem man ej förstâr, är ingen enhet att hoppas. Man måste ock fastställa bestämda grundsatser oin namnens formella beskaffenhet. I Botaniska Utflygter, 2 bandet, har jag uppgifvit de grundsatser jag följer. Sådana namn som Kattklor, Käringtand, Räfrumpa, jemte otaliga likartade, hvilka beteckna helt andra bestämda föremál, kunna svârligen användas i skriftspråket. I denna ordbok har jag likväl upptagit dem, dels för att lemna anvisning till de sâlunda benämnda växternas verkliga namn i riksspråket, dels för att visa huru sväfvande benämningarna äro, vanligen tillagda de mest olikartade växter. För att kuuna urskilja dessa blef det nödvändigt att vid alla icke allmänt kända växter, hvilkas namn jag anser tillhöra riksspråket, tillägga några yttre, lätt $\mathrm{i}$ ögonen fallande kännetecken, utan att vilja lemna nâgon vetenskaplig beskrifning. Äfven har jag bifogat nâgra sprákprof, synnerligast u1 Linnés och vâra poeter's skrifter, men hvilka gerna mâ utelemnas, orr de befinnas mindre lämpliga. I motsats till de Lngelske skalderna, synas de Svenske hafva besjungit, ntom 
Sippor och Hvifvor, mest utländska växter under deras främmande namn.

Vid namnens anförande har jag följt den alfabetiska ordningen och upptagit de sammansatta under deras begynnelsebokstaf, då de äro så fast förenade, att de icke kunna upplösas utan att förlora sin betydelse. Sådant är förhállandet med alla slägtnamnen. Men helt annorlunda förhâller det sig med artnamnen, hvilka blott äro ett närmare bestämmande af slägtnamnet. De äro vanligen så löst förenade, att man lika gerna kan säga t. ex. Hvit Sippa, Svart Poppel, Grön Pil m. m., som Hvitsippa, Svartpoppel o. s. v. I mânga fall lâta de icke sammanfoga sig med slägtnamnet, t. ex. Äkta, Allmän m. fl. För deras rigtiga uppfattning och urskiljande är det äfven af största vigt att hafva dem samlade under slägtnamnen, hvilka ofta först genorn dem erbâlla full klarhet nch bestämdhet.

I sammanhang härmed bör jag fästa uppmärksamheten pâ ett eget förhållande, hvars iakttagande är af synnerlig rigt. Då artnamn tillsättas de sammansatta slägtnamnen, bortfaller vanligen subjektet i dessa och endast predikatet qvarstâr, som slägtnamn; Så t. ex. blir af Kaflegräs, Kampegräs, Slokgräs vid sammansättning Ängkafle, Ängsliampe, Bergslok. På samma sätt af Kronlilja, Klocklilja, Krageblomma, Bulleblomster blir Kejsarkrona, Kungskrona, Snöklocka, Prestkrage, Ängbulle. En stor del, kanske de flesta, af de enkla namnen hafva pâ detta sätt uppkommit, hvilket lâter historiskt bevisa sig. Så har Starr uppkommit af Starrgräs, Monke af Munkbatt, Vass af Hvassrör o. s. v. (I Bot. Utflygter har jag visat samma förhållande vara äfven med de Grekiska namnen.) Men icke alla ord kunna på 
nämnda sätt bortkastas; icke de som afse en viss del af räxten, sâsom rot, blad o. s. v., utan blott dâ subjektet afser hela vïxtens utseende, såsom träl, gräs, lilja, ört. Sprâket vinner derigenom i välljud, ty eljest skulle en dubbel sammansättning uppkomma. I slägten med sammansatta namn kunna artnamnen vanligen icke med dem sammanbindas.

Vid fastställande af växtnamn uppstâr en strid mellan folksprâket och det systematiska interesset. Ehuru bâde slägt- och artbegreppet äro gemensamma för båda, uppfattas de i flera fall olika. Mânga växter, som botanisterna efter minutiösa, icke i ögonen fallande skiljaktigheter upptagit såsom särskilda slägten, äro så lika till det yttre utseendet, att de af folket betraktas som ett, t. ex. Carduus och Cirsium, Schoberia och Kochia. Vid andra tillfällen skiljas i folkspråket växter, som botanisterna förena, t. ex. Hägg och Körs, Oxel och Rönn. Det har efter min öfvertygelse varit ett misstag, att man velat tvinga folkspråket in i de systematiska lagarne. Dessa fordra ett gemensamt slägtnamn för alla arter; men då folksprâket har sjelfständiga namn för underafdelningarna, mâste de bibehållas: t. ex. under slägtena Polygonum samt Ribes och Vaccinium bör hvarje art behâlla sitt sjelfständiga namn, och detta sâ mycket hellre som dessa namn förblifva oförändrade, dâ deremot de systematiska åsigterna alltjemt vexla.

Den svâraste frågan vid sammanskrifvandet af denua ordbok har varit, hvilka växtnamn borde upptagas. Jag har icke kunnat lösa den pâ annat sätt än att jag; med fâ undantag, upptagit alla, som jag hos botaniske och hos andre, godkünde författare funnit anförda, och särskildt alla af Dalin i hans ordbok upp- 
tagna; ingalunda $i$ den mening, att de borde $i$ en ordbok öfver Svenska språket införas, utan för att kritiskt granska dem och uppgifva skälen för en stor mängds uteslutande. Härigenom blir ordboksförfattaren i tillfälle att välja, hvilka narnn enligt det helas plan finnas lämpliga att bibehålla. Om jảg icke upptagit äfreu de i min tanke förkastliga, skulle man lätteligen kunnat tro, att dessa blifvit af mig öfverhoppade eller varit mig okända. De, hvilkas rätt att anses tillhöra riksspråket jag betviflar, har jag utmärkt med †. — Hvad de Svenska växterna beträffar, har jag ansett alla högre (fanerogama) slägten böra upptagas; men att angifva alla artnamn skulle $i$ ett arbete af detta slag hafva ledt till en intet gagnande vidlyftighet. Jag har derföre upptagit endast sådana växters artnamn, som af folket urskiljas; de öfriga höra till specielt botaniska arbeten. Af hundrade inhemska Starrarter kunna på sin höjd tio komma att skiljas af allmänheten.

Hvad de utländska växterna angår, är fältet ändlöst; för min del skulle jag anse, att endast sâdana böra upptagas, som allmännare odlas inom landet eller ock tillföras oss sâsom handelsartiklar eller som äro i inytologiskt eller kulturhistoriskt afseende märkvärdiga. Äfven bland dessa främmande växter har jag upp. tagit alla af Dalin anförda, och jag anser mig böra erkänna, att artiklarne om dem i allmänhet äro af honom med omsorg utarbetade. Jag har dock tillagt åtskilliga, som synts mig med mera skäl böra upptagas, åtminstone $\mathrm{i}$ ett Supplement. De bland ifrågavarande växter, som icke ega Svenska namn, anser jag böra bibehålla sina systematiska eller de $\mathrm{i}$ deras hemland brukliga. Detta gäller företrädesvis om orangeriväxter och om den mängd, som för rabatter årligen införskrifves från Tyskland. Liksom i 
äldre tider de Ty̧ska kräuterbücherna voro vâra inhemska växtnamns värsta fiender, sî äro det nu för tiden de Tyska handelsgä̈rtnernas frökataloger med sina prunkande benämningar, hvilka mánge anse böra föredragas vâra gamla ärliga Srenska namn. Ocksá har det sîrat min fosterlandskänsla, dâ jag t. ex. fítt läsa i tidningar, att redan blomma Primuler, Anemoner och Gager». Icke förstír Srenska folket hrad dermed menas.

Ännu mindre synes man mig böra i en Srensk ordbok upptaga de oflade räxternas ändlösa förändringar. Jag vill här icke tala om de hundratals namn man har pá olika sorter af Roser, Dahlier m. fl., hrilka uteslutande tillhöra gärtner, som ârligen pîhitta nya; men det samma gäller äfven om de fleste af râra kulturräxter, sásom Potates och Kâlsorter, samt om vâra frulitträd. Äfren pâ dessa senare tillkomma ârligen nya, nnen snart försvinnande namn, och de hafra sin plats i pomologiska arbeten. Hrad jag nu yttrat var redan Virgilii âsigt (Georg. 74):

Ilen pá förändrade slag och de skilda namn, som de bära, Finnes ej tal; och hrad båtar i tal att fatta dem alla?

Den som begär dem veta, han räkne i Lybiens öknar Sandens rrande korn, som Zephyrus sprider i rymden, Eller, när Eurus rigtar sitt våld mot seglande kölar, Vảgornas mängd pá Ioniens haf, som brytas mot stranden. 


\section{Anförde författare.}

Aderibeth, G. G. Virgilii Bucolica och Georgica, 2 uppl. Stockh. 1814. ARNELL, L. Sjöfrölien af W. Scott, öfvers. Stockh. 1828. Atterboni, P. D. A. Lyriska Dikter, 1-3. Örebro 1863.

Beiluan, C. M. Valda Skrifter, utg. af P. A. Sondén, 1-6. Stockh. 183ž, 36 . Beskow, B. vow Vitterhetsfürsök I, 3 uppl. Stockh. 1862.

Bromelius, O. Chloris Gothica. Göteb. 1694.

Böttiger, C. W. Samlade Skrifter, 1-4. Stockh. och Örebro 1856 - 69.

Creutz, G. Ph. Vitterhetsarbeten. Stockh, 1795.

DAHLGREx, C. F. Samlade Skrifter, 1-3. Stockh. 1873-75.

DALIN, O. von Vitterhetsarbeten, 1-6. Stockh. 1767.

Franchexits, J. Speculum botanicum renovatum, Ups. 1659.

Franzén, F. M. Skaldestycken, 1-7. Örebro 1824-61.

Fries, E. Botaniska Utflygter, 1-3. Ups. och Stockh. 1843-64.

GEIJER, E. G. Skaldestycken (Samlade Skrifter I. 3), Stocklı. 185 1.

Grafströsr, A. A. Samlade Șkaldestyclien, 1, 2. Stockh. 1864.

GyLlexborg, G. F. Vitterhetsarbeten, 1-4. Stockh. 1795-1800.

Kellgrex, J. H. Samlade Slrifter, 1-3, 4 uppl. Örebro 1860.

KNös, T, Dikter, 1, 2. Ups. 1852, 53.

LEOPold, C. G. AF Samlade Skrifter, 1-6. Stockh. 1814-33.

LiLJEBLAD, S. Svensk Flora, 2 uppl. Ups. 1798, 3 uppl. ib. 1816.

LINDER, J. Flora Wiksbergensis. Stockh. 1716.

Livg, P. H. Samlade Arbeten, 1-3. Stockh. 1859-66.

Linné, C. vox Hans Öländska och Gotländska resa, Stockh. 1745 . - Vestgöta resa, ib. 1747. - Skìnska resa, ib. 1751. - Flora Svecica, 2 uppl. ib. 1755. - Flora Lapponica, 2 uppl. Lond. 1792. - Delicice Naturee, 2 uppl. Stockh. 1816.

Mai.ıströ3r, B. E. Dikter, Stockh. 1876.

Nicaxder, K. A. Samlade Arbeten, 1-3, 3 uppl. Stockh. 1862.

Nordenflicht, H. C. Samlade Skrifter, Ups. 1852.

Nybloir, C. R. Dikter, Ups. 1860. 
Oxexstuersa, J. G. Arbeten, 1-5. Stockh. 1805-26.

P.imberg, J. Serta Florea Svecana, Streng. 1684.

Retzius, A. J. Flora Oeconomica Svecice, 1, 2; Lund 1806.

Riktz, J. E. Ordbol öfver Svenslia allmogespriiket. Lund 1867.

Runeberg, J. L. Samlade Skrifter, 1-5. Örebro 1851-64.

Seillstent, E. Samlade Singer och Visor, 1, 2. Stockh. 1862, 63.

Stagnelius, E. J. Samlade Skrifter, 1, 2. Stockh. 1868.

Svensk Botanik, Stockh. 1779 o. följ.

TEGNÉr, E. Samlade Skrifter, 1-7. Stockh. 1847-51.

Tiluandz, E. Catalogus Plantarum. Åbo 1683.

Wahlenberg, G. Flora Svecica, 2 uppl. Ups. 1833. 
Abborrnate, se Nate. - Abborrgräs (Helsingland) är ett obestämdt namn, uppkommet genom vårdslöst uttal i stället för Abborrnate.

+ Abramsrot, f. $=$ Skogsnäfva.

Anm. Namnet finnes blott en gång antecknadt, nemligen i Linnés Vestg. resa, s. 235, der det uppgifves vara brukligt på Dal och skrifves Abrahamsrot: $i$ hans Flora Svec., n. 617, är det ändradt till Abramsrot. Detta namn, som säkerligen blott tillfälligtvis gifvits, är numera obrukligt; det bör derföre och såsom tillika olämpligt ej medsläpas i ordböcker öfver Svenska språket.

Abrodd (äfven Åbrodd och förvri-. det Ambrett), m., en för sin vällukt odlad art af slägtet Gråbo: Artemisia Abrotanum L. Abrodden hinner under våra korta somrar icke till blomning.

† Abull, m., är endast ett Skånskt bond-uttal af det Danska Abild (på Srensku Apel). Se Linnés Sk. resa 392.

$\div$ Acacia, f., ett talrikt slägte, synnerligast pá Nya Holland, och hvaraf flera arter odlas i orangerier.-Namnet, såsom varande Latinskt,böricke upptagas i Svensk ordbok, om ej i ett bihang.

Ackeleja, f., en så väl vild som odlad prydnadsvärt af Ranunkulaceernas familj, utmärkt genom sina femklolikt böjda sporrar: Aquilegin vulgaris $\mathrm{L}$. Skrifves äfven Akleja och af äldre författare Åkerleja. Af ackelejans blommor beredes blå färg.

Adonis, m., ett örtslägte af Ranunkulaceernas familj, med findelade blad, sköna blommor och talrika småfrnkter: Adonis L. Arter deraf äro:

Höst-adonis, ettårig, med mindre; röda blommor: A. autumnalis L. Od- las som prydnadsväxt under namn af Bloddroppar, Gossen i det gröna.

Vår-adonis, mångårig, med stora, gula blommor: $A$. vernalis $\mathrm{L}$. Varadonisen, som hos oss växer endast. på Gotland och Öland, är en af Srenska florans skönaste smycken.

Anm. Namnet Adonis är fullkomligen Latinskt, men jag har ansett-det böra upptagas i Svenska språket, då de på Oland efter växtställen gifna namnen (Aronsros, Arontorpsros, Kastlöser) icke kunna tillämpas på hela slägtet.

+ Affodil, m., egentligen ett förbråkadt uttal af det Latinska Asphodelus L., ett Liljeslägte, som hos oss hvarken växer vildt eller odlas. På hvad grund namnet af Wahlenberg föres till Sedum Telephium 1., inser jag icke.

\section{Aftōnstjerna, se Stjernlök.}

$\mathbf{A g}, \mathrm{m}$. , ett groft, sträft vattengräs, tillhörande Halfgräsen, med gyttrade bruna småax: Cladium Mariscus R. Br. - Ingen man gifve annan man lof att hugga i oskift skog eller slå ag i oskift myr. Gotl.lagen 25: 3. (Schlyters öfvers.)

+ Agave, fo, vetenskapliga namuet på den växt, som är känd under benämningen Hundraårig Aloe. Bör, såsom fullkomligen obekant $\mathrm{i}$ allmänna språkbruket, knappt upptagas ens i ett bihang till Svensk ordbok.

+ Agersilke, en Skånsk danicism ; kalla's i det öfriga Sverige Åkersilke.

+ Ajamej, i Verml. Elfdalen = ögontröst.

† Akasietråd, se under Ärtbuske.

Al (äfven Alder, I̊l, Ålder), f., ett allmänt, på fuktiga ställen före- 
kommande, Hängeväxterna tillhörande trid, med blomning på bar qvist och klibbiga blad: Alnus glutinosa Wrs.d. Kallas äfven Grönal. Alen förökar sig med ovanlig lätthet. Alarna äro de träd, som tidigast blomma och sist fälla sina löf.

Pilar trifvas på flodernas brädd, och alar $\mathrm{i}$ träsken.

Vid bäcken aspen sina qval ADLERBETH 74.

Förtäljde för den kalla al. ARNELL 12. Alen är en bild af idoghet,

Och af höjdens stormar hon ej vet.

Grå-al, se Arre.

Alant, m., en prydlig växt af Hålkblomstriges familj, med stora gula blomhufrud: Inula Helenium L. Hos äldre förf. äfven Alunarot. Alanten är en af de väldigaste inhemska örter, och roten användes $\mathrm{i}$ medicin.

$A n m$. Namnet Alant är redan i sjunde seklet antecknadt bland Vestgötarne i Spanien (jfr Bot. utf. 1:143), och ännu bibehållet $\mathrm{i}$ Tyska, Danska och sydsrenska folkspråket. Numera i riksspråket förvändt till det mycket missledande Alandsrot och af en del skriftställare till Elinsrot, Helenerot, under förmodan att namnet kommer af Helenium, som dock härleder sig från Grek. Ł̇los, kärr.

$\mathbf{A l g}$, f., en talrik klass bland Groddtrådsväxterna, hvars slägten växa i vatten; det Latinska Alga. Hit höra Tång, Slake, Söl m. fl.

Ringare än på hafvets strand uppkastade algen.

(nprojecta vilior algan, vIRG.Ecl.7:42.)

\section{. + Algräs, Rosl., Alskogsgräs, Österb. = Mjödört.}

† Alkanna, f., färgstoft, som erhålles från Orienten af Alkrnna tinctoria TAUscr (af Linné förd till slägtet Anchusiz).

+ Allbotsrot, Nerike = Äng-anis.

Alm, f., ett allmänt löfträd, blommande på bar qvist, med hela, vanligen sträfva blad: Ulmus L. Almarnas vingade frukt kringföres vida af vinden.

De täta almars skjul en fåfäng tillflykt ger. CREUTZ 15
Flera förändrade slag man finner af härdiga almar. $\triangle$ DLERBETH 74 . Almar i ståtlig viaxt sig sprida för himmelens vindar. DAFLGREN 1: 141.

Allmän Alm (U. montana Ss.) finnes öfver hela landet, upp till Vesterbotten.

Kork-alm (U. campestris $\left.\mathrm{S}_{\mathrm{S} .}\right)$ förekommer på Öland och Gotland; har mindre löf än den föregående och korkartad bark.

Vres-alm (U. effusa Wruzd.) finnes äfven på Öland; är skild frain Korkalmen genom långt skaftade blommor.

Almecke, Medelp., Almocke, Vesterb., Almycke, Angerm. = Kropp. - Detta namn (lånadt från Lapskan?) är så allmänt, ehuru olika uttaladt, i de Norrländska landskapen, att jag ansett det förtjena upptagas.

Aloe, m. 1) Ett artrikt örtslägte bland Liljevärterna, pâ Cap, med köttiga, saftfulla' blad, hvilkas saft användes i medicin: Aloë L.

2) Amerikansk eller vanligen s. $k$. Hundraårig Aloe, hvilken tillhör ett annat slägte: Agave americana $\mathrm{L}$.

3) Indisk Aloe, bekant för sin egenskap att motstå förruttnelse: Aloëxylon Agallochum raour. Denna är den under namn af Aloe i vår bibel omtalade växten.

4) Svensk Aloo benämnes af Tillandz $\mathrm{m}$. $\mathrm{fl}$. slägtet Dyborre.

Alpros, f., en skön buskväxt af Ljungfamiljen, tillhörande södra Europas fjell, och i största prakt uppträdande på Himalaya : Rhododendron L. En liten förkrympt buske af detta slägte finnes äfven på våra fjell: Lapska Alprosen, R. lapponicum $\mathrm{W}_{\mathrm{G}}$.

Hvar morgon en alpros jag fäster i hatten

Och börjar min 'vandring med stafren i hand. BötTieER 1: 283.

+ Alrot, Gestrikl. = Hönsbär. 
+ Aluruna, f., ett mycket gammalt Tyskt namn på en $i$ Norden icke förekommande växt of Bolmväxternas familj: Atropa Mandragora I.'Växten har användts vid besvärjningar och varit föremål för mångfaldigt skrock, hvarigenom namnet kommit till oss. I roten har man trott sig finna bilden af ett foster. Till Svenska språket hör namnet icke.

Alsikeklöfver, se Klöfver.

† Alster, ett rent af diktadt namn, som, af missförstånd inkommet i våra ordböcker och floror, måste alldeles utstrykas. Benämningen är, efter Wahlenbergs förmodan, uppkommen af $\mathrm{Hal}$ ster, enligt Roslagska uttalet, och har för den växtens likhet med Benveden blifvit af missförstånd öfverförd till denna senare. Namnet förekommer ingenstädes i vårt folkspråk och ej heller i något af de beslägtade språken, såsom deremot alla andra buskars och träds namn göra.

Altea, Althea, f., en mångårig ört af Kattostfamiljen, odlad för sin i medicin använda rot, Althérot: Althcea officinalis L. Althéroten innehåller renaste växtslem.

\section{Alvarlök, se Gräslök.}

Amarant, m., ett med Mollaväxterna närförvandt örtslägte, hvaraf flera arter odlas på fritt land som prydnadsväxter, synnerligen Amarantus caudatus L., vanligen kallad Kalkonsnabel. En hit förd inhemsk art (A. Blitum L.) föres numera till eget slägte: Euxolus RAFTx. Jfr Bläsa.

Anm. Namnet är visserligen utländskt, men fullkomligt nationaliseradt.

† Amaryllis, f., en utländsk praktlilja, endast odlad i varmhus: Amaryllis formosissima L. - Vill man upptaga den i Svensk ordbok, borde man med lika skäl der upptaga flera hundrade andra orangeriväxter.

Amur, m., är enligt alla äldre författare ört3lägtet Melilotus (ı.), ett med
Klöfver förvandt slägte, men lätt skildt genom utdragna blomklasar; hos Klöfvern äro blommorna samlade $i$ ett hufvud. (Detta gamla goda namn har man i senare tider utbytt mot det Grekiska Melilot eller dess öfversättning Honungsklöfver.) - Amuren torkad har en söt, behaglig lukt.

Amurgrå̉s, n., är ett namn, som tillägges flera gräs, hvilka torkade hafva samma vällukt som Amuren, nemligen $\nabla$ årbrodd, Hässlebrodd, Myskegräs.

Amört, f. = 1) Äng-anis, hvilken anses öka mjölken hos ammor; 2) Lundkovall, Bleking, af okänd anledning.

Ananas, m., en i varmhus odlad tropisk växt: Ananassa sativa Lrisnu. Denna som en synnerlig läckerhet högt värderade växt, införd till Sverige 1726 , är så allmänt bekant, äfven af poeter (bland andre Oxenstjerna) besjungen, att den måst upptagas.

Andigrås, Vesterg. = Braxengräs. Andhafre, Vesterg. = Andmat.

Andmat, m., mycket små, på vattnet flytande bladlika stjelkar; örtslägtet Lemna-L. Andmaten betäcker ofta stillastående vatten med en grön matta.

Andorn benämnas efter Tyskan åtskilliga Sugeväxter, såsom Hvit-andorn $=$ Kransborre, Svart-andorn $=$ Bonässla, Vatten-andorn = Strandklo. Enligt Tyskan är namnet $m$. , men i Svenskt uttal n. Ehuru främmande och öfverflödigt, förekommer detta namn så ofta hos äldre skriftställare, att det måst upptagas.

Andromeda, f. Sa benämnes Roslingen i poesi, t. ex. af Atterbom (1:20) och Franzén. Linné lemnar öfver den sammaten poetisk beskrifning i Fl. Lapponica, p. 126.

Ingen i behag Linnea öfverträffar,

Dock sjelfve mästarns röst af Andromeda vans,

Då han åt Flora knöt från fjellarna en krans. ERANZEN 4: 63 . 
Andvide, n., en med Roslingen närförvandt liten buske i norra Vesterbotten och Finland: Cassandra calyculata Dos.

Anemon, f., benämning på de sydeuropeiska, som prydnadsväster stundom odlade arterna af slägtet Sippa: Anemone hortensis L. Brukas blott i poesi.

Solen har tecknat med kärlekens drag sitt barn Anemonen. GRAFSTRŌM $2: 250$.

Angelika, f. $=$ Qvanne. Namnet är brukligt endast i medicin.

$\div$ Angusturabark, m., en medicinsk drogue, som erhalles af den i Columbien växande Galipea officinalis Harcock.

Anis, m., en odlad, cttårig växt af Umbellaternas familj: Pimpinella Anisum L. Anisfrön hafva en behaglig kryddsmak.

Äng-anis, en rild, mångårig art af samma slägte: $P$. Saxifraga $\mathbf{L}$.

$\div$ Anisblomster, Nerike $=$ Linnésört. Namnet afser blommornas lukt.

$\div$ Anisros, Upl. = Knylbräcka. fammets anledning inses svârligen.

Annbok, f., ett rackert, i södra Sverige väsande löfträd af ̊llonträdens familj: Carpinus Betulus L. Benümnes äfven Hvitbok. Jfr Avenbok. Annboken lemnar ypperligt slöjdvirke. Annbokskogarne utmärka sig genom synnerlig täckhet och liflig grönska.

$\div$ Apebrödsträd, n., ett genom sitt utomordentliga omfang, men sin lösa red, utmärkt träd i Afrika: Adansonia digitatı $\mathrm{L}$.

Apel, f., ett så räl vildt (Skogsapel) som odladt kürnfrukttriad: Pyyrus Malus i. Frukten kallas Äpple och dgrefter trädet äfren Äppleträd. Af đen rilda A peln har man trå bestämda artförändringar, skilda genom fruktens smak: Sur-apel och Besk-apel. Af den odlade finnas talrika sorter med egna namn, men dessa äro mycket rexlande, och nya sorter uppdragas ârligen, hvarföre de icke förtjena upptagas $i$ en ordbok, utan tillhöra speciella pomologiska arbeten. (Jfr Eneroths Poimologi.) - Af den ur Sur-apelns frukt utpressade :saften beredes en dryck, kallad Cidleth.

Af apelns vilda växt bereder konstens hand

En dryck, ännu begärd i sjelfra drufvans land.

OXEXSTJERNA $2: 152$.
tren befruktade blif-

På aplarna blomstren befruktade blif-

Af sprittandè solstrålars eldiga brand. DAHLGREN $1: 378$. Snöblommor yra från aplarnas topp. Dens. 1: 419 .

Apelsin, m., den guldgula frukten af Orangeträdet (se Orange): Citrus Aurantium $\mathrm{L}$.

Aprikos, f., benämning så väl på frukten af ett träd, tillhörande, slägtet Slån, som på sjelfva trädet: Prunus Armeniaca L. Aprikosen trifves i Srerige under bar himmel endast i sydligaste delen.

Aprikosers växt, dem sommaren förgrlt Och svarfvat deras klot och dem med sötma frlt.

Ard, se Arre. OXENSTJERAA 2: 124.

$\div$ Areka-palm, f., en palmart i Ostindien, Areca Catechu L., af hrilken erhålles Areka-nöten, terra Catechu.

\section{$\div$ Ayonsros, Arontorpsros, Ö- land $\mathbf{e}$ Varr-adonis.}

Arre, n., en art af Alslägtet, med gråludna, icke klibbiga blad: Alnus incana wrzz. Kallas rättare Grå-al, af äldre förf. Hvit-al.

$\div$ Arrowret, f., hraraf beredes det i handel fretrommande närande Arrowmjölet, erhålles af Maranta arundinacea L., som tillhör Scitamineernas familj.

Aitskock, Artskocka, f., benämuas trenne vidt skilda räxter, bada dock tillhörande Blomhålksvästerna: 
1) Jord-artsisock, den ätliga, söta stamknölen af en art Solros: Helianthus tuberosus 1.., hrilken väl uthärdar vårt klimat, men icke hinner till blomning.

2) Bron-artskock, en tistelräxt, hvars nedtill något köttiga hålkfjäll ätas som en läckerhet: Cynarc Scolymus $\mathbf{L}$.

Anm, Uttalas och skrifves origtigt Ärtskock, Artskocka. Namnet är det Fr. artichaut, T. artischocke; med art har växten ej den ringaste förrandtskap.

Arun, m., örtslägtet Erythr’ea kicH., utmärkt af sina röda blommor och sin beska smak, närbeslägtadt med Stålörten. Arun är ett godt, magstärkande medel.

Anm. Detta särdeles gamla och märkvärdiga namn är ännu brukligt i Tyskland, Danmark och Skåne (se Linnés Sk. resa 277 ). Mycket origtigt är det förbigånget $i$ Dalins ordbok, liksom de flesta namn, hvilka ej hafva sin tydning i nuvarande språket. Men just dessa äro de för språkforskaren dyrbaraste.

Arv, m. (Isl. $\operatorname{ar} f$. ) Gemensam benämning på flere småväxter, som finnas mest på odlade ställen, och motsvarande T. Miere, E. Chickweed. Nyttjas endast i sammansättning och ingår i en mängd växters namn.

$\div$ Asblomma, f. Detta namn, som det sydafrikanska örtslägtet Stapelia L., hvilket stundom odlas i orangerier, erhållit för sina stinkande blommors skull, synes mig onödigt, då det aldrig han komma att ingå $i$ allmänna språkbruket. För väster af denna art är det oförändrade Lat. namnet att föredraga.'

Ask, f., ett prydligt inhemskt löfträd af Ligusterns familj, men utan både blomfoder och blomkrona : Fraxinu: excelsior $\mathrm{L}$ : Asken var fordom, och är ännu bland allmogen, ett heligt träd. Asken Yggdrasil. - Askarna äro skogens förnäma; de slå sist ut sina löf och fälla dem först.
Jag askens ädla växt, jag almens krona vördar. OXENSTJERNA 2: 93.

På kullar stodo ask och ek,

Som kämpar uti bardalek. ARveLr 12 . $\div$ Askört, f., ett synnerligen förolyckadt namn, bildadt efter Lat. Cineraria; men det befinnes, att de räxter, hvilka man tillagt det, alldeles icke tillhöra nämnda slägte.

Asp, f., ett allmänt Hängeträd, utmärkt af sina darrande löf och honträdens ymniga fröfjun; tillhör Poppelslägtet: Populus tremula L. Aspen utgör gemenligen små lundar, ... sällan träffar man den blandad med andra trädslag i skogar. RETZIUS 2: 548 .

De höga aspar fläta sina grenar

Utöfver grafren. GEIJER I. 3: 300 . Susen er grafsảng, susen af sorg, I darrande aspar! MALMSTRÖI 7 .

Aster, m., ett talrikt slägte, tillhörande Blomhålksväxterna, med stjernlikt ordnade strålblommor: Aster L. Flera arter odlas som prydnadsväster. Jfr Stjernros.

Astrakan, m., en odlad, mör och söt ädlare äpplesort.

En astrakan, der dagen genomsken,

Som en kristall, sã klar och ren.

Aurikel, m., en odlad, i många färger skiftande art af slägtet Hvifva: Primula Auricula L.

Aurikelns mångfärghet, som sig i låghet gömmer. OXENSTJERXA 2: 121.

Arenbok, ett namn bildadt efter D. avnbög; enligt rent Srenskt uttal heter trädet Annbok.

Axing, se Äxing.

Axlosta, f., ett från Losta skildt slägte, med enkelt ax; endast de lägsta småaxen äro skaftade: Brachypodium P. BEAUV.

† Axsvingel, se Svingel. Ax=ärenpris, se Äronpris. 
Backbränua, f., arterna af slägtet Arábis Lo, örter med små hvita blommor och långa, smala skidor; egentligast A. Thaliana I.

$\div$ Backbär, $\mathrm{n} .=$ Backsmultron. lika.

Backhumle, 'Dal., Hels. = Röl-

\section{Back-klöfver, se Klöfver.}

Backrinka, se under Binka.

Backsippa, se Vippa.

Backstar', se Starr.

Backsöta, f., ..en art af slägtet Astragalus $\mathrm{L}$. utaf Ärtväxternas familj, med tvårummig, krökt, nästan trekantig fröbalja: A. glycyphyllus L. Roten har sötaktig smak, likt Lakrits, hvarföre den af äldre förf. (Franckenius, Tillandz) förveslades med Lakritsroten.

Backtimjan, se Timjan.

Backvippa, se Vippa.

Backväpling = Back-klöfver.

+ Baggpungar, $\mathrm{m}$. pl. $=$ Tarald.

Baggsöta, f., en art af slägtet Stålört, med stora purpurröda blommor: Gentiana purpurea L. Förekommer endast på vestliga Norges fjell och benämnes der Söte, ehuru i hög grad besk (således ett skämtnamn).

Anm. Redan i äldre tider har (enligt Rudbeck) denna ört, för sina utmärkta medicinska egenskaper, blifvit sassom handelsartikel införd från Norge (öfver Dalarne) och deraf här i riket fảtt namnet Bagysöta, d. v. s. Norsk söta. Linné, som ej sett den blommande växten, hänförde honom till en närbeslägtad, gulblommig art frăn Schweiziska alperna: Gent. lutea, hvarföre han ännu i våra ordböcker origtigt föres till denna.

\section{†Baisk-lök, Gotl. = Gräslök.}

Baldersbrå, f., en ört snarlik Kamillblomster och Surkulla, med findelade blad och sköna hvita strålblom- mor, men utan märkbar lukt, samt trekantiga frukter: Chamomelum inodorum Vx. (Tripleurospermum Scrouxz.) I vårt allmogespråk är numera detta namn förvändt till Ballerbro, Balse$b r o, B a v^{\circ} b r o$, och hänfördt till slägtet Kullor, men det har bibehållit sig oförändradt på Färöarna och Island (Baldrsbrá, Balders ögonbryn), der det äfven rigtigt tillägges förstnämnda ört.

Anm. Den stora likheten mellan arterna af slägtena Afatricaria och Anthemis förklarar lätt, hvarföre dessa förvexlas och namnet Baldersbrå öfverförts till sistnämnda slägte; men att det rätteligen tillkommer endast Mfatr. inodora L., lider intet tvifvel, ty på Island och i de nordliga länderna finues icke den stinkande, otäicka Surkullan, till hvilken man velat hänföra det.

Balsamin, f., en för sina prydliga röda blommor allmänt, äfven i torpstugor, odlad krukväxt, hörande till slägtet Springkorn: Impatiens Balsamina L. Balsaminens fädernesland är Ostindien.

\section{Balsampoppel, se Poppel.}

Balsamträd, n., en gemensam benämning på flera trädslag i de varmare länderna, af hvilka balsamen erhåles, såsom Perubalsam af Myrospermum peruiferum Dxo., Tolubalsam af Myrosp. toluiferum Rrcr., m. fl. Mest bekant är Meccabalsam, af Balscmodendron gileadense Kuxтr, hvilken användes $\mathrm{i}$ medicin och. är den $\mathrm{i}$ bibeln omtalade balsam.

+ Balsamäpple, n. Under detta namn anföres i Dalins ordbok Momordica Balsamina L., hvilken lämpligare kallas Balsamgurka; men ingendera förtjenar upptagas i Svenska språket.

Bambu, m., Bamburör, n., ett i de tropiska länderna växande trädartadt gräs (Bambusa Souñs.), som hinner flere hundra fots längd, med ben- 
hårdt, men - såsom hos öfriga pipigt rör, hvaraf man i nämn der bygger hus $\mathrm{m}$. $\mathrm{m}$.

Banan, Bananas, m., en ståtlig, mångårig trädartad växt, tillhörande Etthjertbladsväxterna: Musa Sapientum 1. Bananernas frukt är söt, välsmakande och $\mathrm{i}$ de tropiska länderna högt värderad.

Bandpil, f., en afdelning af Pilslägtet (Salix L.), buskar med långa, smala, sega skott och blad: Vetrix Fr. De lemna det yppersta material till tunnband, korgar, vidjor m. m., hvarföre de ofta odlas i stort. De mest bekanta arterna äro:

Gul Bandpil, med gröna, i kanten sågade, vågiga blad: Salix undulata Eнгя. Upland, Öland.

Holländsk Bandpil, med på undra sidan gråludna, helbräddade blad: $S$. lanceolata $\mathrm{Fr}_{\mathrm{r}}$. Skåne, Halland.'

Tysk Bandpil, se Korgpil.

I allmogespråket räknas äfven Mandelpilen till Bandpilarna, ehuru från dem vida skild.

\section{Bandtång = Bândling.}

Bandvide, se Vide.

Barken=, Barkena-rot, f., benämnes i Skåne och Halland den vilda Morroten.

Anm. I lingvistiskt hänseende är detta namn märkvärdigt, emedan Morrotens benämning i alla Finska språk dermed sammanhänger, t. ex. Porkkana i Finland, Porkan i Estniskan, Borkkana i Wotiskan.

Barrlind (Lind med barr), f, kallas Idgranen i Göta rike. Namnets anledning är, att sistnämnda träd lemnar bast liksom Linden. De s. k. Barlinds-öarna i Göteborgs skärgård hafva sitt namn af detta träd.

Barrträd, n., träd med barr, i motsats till löfträd, utgörande en mycket egendomlig växtfamilj: Coniferce L. Vi ega i Sverige fyra arter inhemska barrträd: Fur, Gran, Idgran och En, samt åtskilliga planterade: Lärkträd, Silfvergran, Cypress m. fl.

Basilik, f., en mera sällan (i drifbänk) odlad kryddväxt af Sugeväxternas familj: Ocymum Basilicum L.

† Bastträd, Finland m. fl. ställen $=$ Lind.

Batatas, m., en i de tropiska länderna odlad jordfrukt af slägtet Vinda : Convolvulus Batatas L. Rotknölarne af Batatas hafva mycken likhet med Potates, ehuru dessa båda växter icke äro förvandta, och namnet Potates är egentligen en förvridning af Batatas.

Battram, m., hos alla äldre förf. rigtigare Berthram, efter det Grekiska Parthenium, en med. Kamillblomster närförvandt ört, men mångårig och med äggrunda bladflikar: Pyrethrum Parthenium Sx. (Matricaria Parthenium L.) Jfr Mattram.

Beckblomster '(allmänt), Bekrisper (Smål.), se Tjärblomster.

Belladonna, f., en mycket giftig, men i medicin använd växt: Atropa Belladonna L. Hör till familjen Bolmväxter.

Benved, m., en i södra Sverige växande buske, skild från alla andra genom femkantiga, femrummiga, rosenröda frukter (ej bär): Eionymus europaus $\mathrm{L}$.

Anm. Namnet Benved tillkommer otvifvelaktigt rätteligen denna växt, enligt så väl vårt folksprăk (se Linnés Sk. resa 265,392 ) som de närbeslägtade språken. Namnet Alster har aldrig funnits, utom $\mathrm{i}$ böcker. Benämningen Käringtand (på Öland) är $i$ alla hänseenden förkastlig. - Genom förvexling har namnet Benved blifvit fördt till să väl Kornell som Try.

+ Benvälla, $\mathrm{f}_{\text {. }}=$ Vallört.

+ Benvärksgrås, Österb. $=$ Linnésört.

Benzoe, m., ett på Moluckerna inhemskt träd: Styrax Benzoin DRYAND., 
af hvilket erhâlles det $\mathrm{i}$ handel förekommande Benzoeharts, hvaraf fas Benzoesyra.

Berberis, m. = surtorn. Det förra namnet är likväl mest brukligt i skriftspråket.

Berberisrost, se Rost.

Bergamot (uttalas oftast Pergamott), m., en sorts runda, mycket saftiga Päron.

Bergamotolja, f., en eterisk olja af pomeransskal.

Bergbråcka, se Bräcka.

Bergdusk, m., en prydlig fjellväxt af slägtet Bräcka, med yfvig blomruska, hvita blommor: Saxifraga Cotyledon $\mathbf{L}$.

Berggrőe, se Gröe.

Berggyllen, se Gyllen.

Bergklöfver, se Klöfver.

† Bergknopp, Linné, en art Fetknopp (Sedum rupestre L.).

$\div$ Bergmynta $=$ Harmynta.

Bergrör, se Rör.

Berg-skrạbba, f., en mångårig ört, växnnde på Öland och Gotland, med talrika blå, i ett hufvud samlade blommor, fyra fria ståndare: Globularia vulgaris L. Benämnes i trädgårdsspråket vanligen Blåboll.

† Berg-skälla, f., Liljeblad $=$ Svarthö.

Bergslok, se Slokgräs.

Bergspring, n., smärre Bräkenarter, tillhörande slägtet Asplenium L., växande i bergspringor.' Sjelfva hällarna grönska om vintern af Bergspring.

Bergsyra, se Syra.

$\div$ Bergsöta = Stensöta.

Berthxam, se Battram.

Beskapel, se Apel.

Besksöta, f., en klängande buske af Bolmväxternas familj, med knippevis sittande blå blommor och röda bär:
Solanum Dulcamara L. Bären kallas Hållbär Smål., Ormbär Österg., Trollbär Söderm., Villbär Verml.

Beta, f., ett för bordet, för sockerberedning och till foder allmänt odladt örtslägte: Beta L. Man skiljer deraf flera arter: Rödbeta, Hvitbeta, Foderbeta.

Betel, m., som i Orienten allmänt tuggas saisom tobak, beredes af bladez utaf Piper Betle L. och af irukterna utaf Areca Catechu L.

Bibinell, förderfvadt uttal af Pimpinell.

+ Bigarrå, m., en artförändring af Körsbär.

Binda, $f$. Detta namn tillkommer rätteligen afdelningen Helxine af slägtet Polygonum eller Slideknä, hvars arter slingra sig omkring andra växter, såsom Àkerbinda (Polyg. Convolvulus L.) och Löfbinda ( $P$. dumetorum $\mathrm{L}_{\text {.. }}$ ), den förra växande på åkrar, den senare bland buskar. Oegentligen är namnet tillagdt dels Akervindan, emedan denna likaledes omslingrar andra växter, t. ex. benämningarna Drabinda, Snarbinda (snärjbinda), och dels Snarrefvan, t. ex. Hummelbinda (Dalarne), Linbinda, Bindsleskorf (se Skorf).

Bingel, m., en mångårig ört med små, gröna, enkönade blommor, utan kronblad, och med tvâknölig frukt: Mercurialis perennis L. Torkad blir Bingelen svartblå; hvilket i förening med det Latinska namnet förvärfrat honom rop för magiska egenskaper. Bingelen när en skadelig växt föx fưren, sấ väl som för menniskann. Linnés Öl. resa 146.

Binka, f., örtslägtet Erigeron $\mathrm{x..,}$ skildt från öfriga Boväxter genom sina smala, nästan trådlika strailblommor. Rödbinka (E. acris L.) är allmän.

Anm. Hos äldre förf. föres denna växt till slägtet Gråbo och benämnes af Franckenius och Tillandz Rödbo. Namnet Binka är en flexion af $B o$, liksom Böna, Bynke. Namnet Rinka - i Baclrinka, Dal. - är troligen samma namn, men föres till Achillea. 


\section{Björkticka, se Ticka.}

Björubrodd, m., en liten, med Liljorna närbeslägtad ört i fjelltrakter: Tofieldia borealis Wa. En större art af samma slägte finnes på Gotland.

Björnbärsbuske, m., ett gemensamt namn på flera buskarter af slägtet Rubus eller Hallon, med svarta bär - Björnbär eller rättare Björnhallon - hvilka arter af Linné innefattades under namnet Rubus fruticosus. Jfr anm. vid Käringbär.

Anm. Anledningen till namnet Björnbär är svårförklarlig, då björnen aldrig vistas $\mathrm{i}$ de trakter, der Björnbärsbusken växer. I äldre tid kallades denna buske Brumbär, och sả ännu vid vestra kusten; må hända härleder sỉg detta namn från det fornnordiska brum, löf, emedan bären sitta bland löfven, hvilket för de buskartade Rubi är högst karakteristiskt. Sedan det gamla ordet utdött ur språket synes man hafva förändrat brumbär till björnbär, dertill kanske föranledd af idéförbindelsen mellan björn och brumma.

Björufloka, se Björnloka.

+ Björnkam, m. = Kambräken.

Björnklo, f. Dermed öfversättes i ordböcker Grek. Acanthus L., som ej finnes i Norden, en i mytologiskt hänseende märkvärdig växt, hvars prydliga blad utgöra siraterna på Kofinthiska pelare. Man har velat finna likhet mellan dessa blad och Björnlokans, hvilken derföre af äldre förf. kallas Björnram.

Björnloka, f.(äfven Björnfloka, Björuram, Björustut), en mycket storväxt Umbellat, med parbladigt sammansatta, sträfva blad och platta frukter: Heracleum Sphondylium L.

Björnmossa, f., en högväxt mossa, som användes till qvastar, viskor o.s.v. Polytrichum commune L. Dess utskjutande frukt kallas Dufråg, Gökråg, Kråkbjugg, Kråkhvete m. fl. loka.
Blacka, f., de större arterna af slägtet Ulva L. Bohuslän.

Bladgrus, n., Bladludd, m., svamplika utväxter på âtskilliga träds löf: Erineum Pвпs. och Phyllerium Fı. Bildas af insekter.

Bladmossor eller Löfmossor, en talrik familj bland Groddtrådsväxterna, utgörande hufvudgruppen i Mossornas klass, med fria blad och med fröhus, täckta of ett lock: Bryacece BArтr. Samtliga arter benämnas Mossa, och de mera framstående, af allmänheten skilda, upptagas under Mossa.

Blek- tillsättes åtskilliga växter såsom artnamn, t. ex. Blek-kattost (= Rosenkattost), Blekstarr (Carex pallescens Lo), Blekväpling (=Alsikeklöfver) $\mathrm{m}$. $\mathrm{fl}$.

Blidnässla, f., en till Nässlefamiljen hörande, polygamisk ört med små hvitgröna blommor: Parietaria officinalis L. Förekommer hos oss endast förvildad.

+ Blindmjöl, $\mathrm{n}_{.}=$Röksvamp.

Blindnässla, f, ett namn, som tillägges flere Sugeväxter af slägtena Dån och. Plister, i synnerhet Hvitplistern: Lamirm album $\mathrm{L}$.

+ Blindsvamp = Röksvamp.

Blink, Vattenblink, m., vattenväxt af Hvifveväxternas familj, med findelade blad, hvita, något rödletta, hastigt affallande blommor: Hottonia palustris $\mathrm{L}$.

Bloddroppar, se Adonis.

+ Blodgräis, Hels., enligt uppgift $=$ Boört. Namnet är troligen en felaktig uppteckning i stället för Bogräs.

Blodhirs, se Hirs.

+Blodknopp, m. = Johannesknopp. Jfr Mansblod.

Blodnåfva, se Näfva.

Blodplättlaf, se Laf. 
Blodrot, f., en liten art af Fingerörtslägtet, med fyra kronblad: Potentilla Tormentilla Neor. Roten har mycket adstringerande egenskaper och är ett af de verksammaste medel motrödsot, diarrhé o. s. v.

Blodstilla, f., Blodtopp, m., en mångårig ört af Brumväxternas familj, utmärkt genom sina axlika, blodröda blomhufrud i toppen af den bara stjelken: Sanguisorba officinalis $\mathbf{L}$.

Blomhålksväxter eller Hålk: blomstrige benämnas Synantherece Rror., den största och artrikaste familjen bland Tråhjertbladsväxterna, med talrika blommor inom en gemensam hålk på ett gemensamt fäste, fem sammanväxta ståndarknappar, och en frukt under hvar blomma. Fördelas i tre underfamiljer: Boväxter, Tistelväxter och Fibleväxter, hvilka särskildt upptagas.

Blomkål, se Kål.

Blomtistel = stjerntistel.

Blomvass, m., en prydlig, säflik vattenväxt bland Etthjertbladsväxterna; de talrika, liffärgade blommorna sitta i blomflock: Butomus umbellatus $\mathrm{L}$.

+ Blundblomma, Dal. = Höstfibla. Namnet afser de tidigt sig slutande blommorna.

\section{Blåboll = Bergskrabba.}

+ Blåbuk, m., en i Göta rike allmän benämning på 0don.

Blåbärsris, n., en liten buske af Ljungväxternas familj, med årligen affallande löf och mörkblå bär: Vaccinium Myrtillus $\mathrm{L}$. Bären äro ätliga.

Blåeld, m., en mycket sträfhårig växt af de Skrufblomstriges familj, med rik blomruska, sköna, oregelbundna. blomkronor: Echium vulgare L. Om denna växt yttrar Linné, Sk. res. 206, att den i Skåne, under namn af
Klåkuntor, vvärte på de sluttande fälten i den myckenhet, att jag aldrig sett dess like, hvaraf ock skedde, att dessa fält på långt håll lyste med en så präktig och högblå färg, att jag aldrig sett något fält, som i fägring häremot kunnat förliknas".

Blågull, n., se Blåljus.

Blåhallon, n., en buskväxt af slägtet Rubus, med svartblå bär: R. casius L.

\section{Blåklett, se Klett.}

Blåklint, m., en allmänt bekant växt bland vintersäden, med blå blommor i ett hufvud, strålblomstren trattlika: Centaurea Cyanus L. Har talrika benämningar, såsom Blågubbar, Blåhattar, Blåkorn eller Blå Kornblomma, Blålilja (Halland), Blå Ringblomma, Blåtoppar, Blåört, att förtiga de obestämda, appellativa, t. ex. Akerros och Kornros, saint de oefterrättliga Dalska, hvilka synas vexla i hvar socken. Nagra andra, mera sjelfständiga, anföras särskildt. - Växtens rigtigaste namn torde vara Blåklett.

Ceres, blidkad sjelf, den blåklint tåligt ser,

Hvars ogräs àt dess drägt likväl en prydnad ger.

OXENSTJERNA 2: 123.

Blåklocka, f., ett artrikt örtslägte, med bla, klocklika blommor och hvit, mild mjölksaft: Campanula L.

Somliga (elfvor) klämta sitt bingelibing Uppả blåklockor, som fuktiga drypa. DAHLGREN 1: 80 .

De af allmänheten skilda arterna äro:

Allmän eller Liten Blåklocka : $C$. rotundifolia L., med runda rotblad, smala stjelkblad.

Stor Blåklocka: C. persicifolia $\mathrm{L}$, med alla bladen smala, mycket stora blommor.

Hässleklocka: C. latifolia L., stor, med äggrundt lancettlika blad. Kallas äfven Hässlekål.

Knylklocka: C. rapunculoides L., med rotknölar; ett högst elakt ogräs i trädgårdar. Jfr Rapunzel. 
Nässleklocka : C. Trachelium L., med triangelformigt hjertlika bad.

Rofklocka = Rapunzel.

Toppklocka, särskildt upptagen.

† Blåknapjar = 1) Knappvädd ; 2) Monke.

† Blåkunta, plur. -or, f. Denna benämning för Echium vulgare lemnar ett märkligt exempel på den vårdslöshet, hvarmed man behandlat växtnamnen. I källorna för namnet - Linnés Sk. resa, s. 177, 206; Flora Svec., n. 168 - och såsom jag sjelf hört af allmogen i Skåne, lyder det Klăkunta; men emedan man ej känt dess betydelse (kunta, cunnus), har man godtyckligt ändrat det till Blåkunta, hvilket är någonting helt annat. Jfr Bläeld.

Blåkål, se Kål.

Blåljus, n., en i Jemtland vild, men eljest såsom prydnadsväxt allmänt planterad ört, med parbladiga blad, hjulformiga, blå blommor och trerummigt fröhus: Polemonium caruleum. L. Kallas i trädgårdsspråket Blå riddare och Blåljus.

Anm. Namnet uppgifves olika; af Linné Kosjuss, hvilket lär vara sammandraget af Kongsljus. Då denna benämning icke är användbar, har jag ändrat den efter trädgårdsspråket. Wahlenberg åter benämner växten Blågull.

Blålåcka, se Låck.

Blåmonke = Monke.

Blåmunk, m., se Munkskalle.

$\div$ Blåseranunkel, enligt Liljeblad Ranunculus sceleratus $\mathbf{L}$.

\section{Blåsestarr, se Starr.}

$\div$ Blåsgom, m. = Drakblomma. Detta af Liljeblad bildade namn är ieke antaget och bör utgå.

\section{Blåsippa, se sippa.}

Blåslaf, se Laf.

† Blåslok och Blåtåtel = Blått Senegräs. Dessa båda i systematiskt intresse bildade namn hafva icke ingått i allmänna språkbruket, och då växten Senegräs nu befunnits vida skild både från Slok och Tåtel, måste de utgå.

\section{Blåsmäre, se Smäre.}

Blåstarr, se Starr.

Blåstjerna, f., ett slägte bland Liljeväxterna, med blå, till basen delade, stjernlika blommor: Scilla L. En hos oss naturaliserad art är S. italica L.

\section{Blås-tång = Knapptång.}

Blåsuga, f., örtslägtet Ajuga L., tillhörande Sugeväxternas familj, men skildt från öfriga genom saknaden af blomkronans öfre läpp och genom blå blommor. Om dess vanligare namn Kärinkruka och Krukört, se Krukört.

Blåsärt, $\mathrm{f}$. Så benämnes i Dalins ordbok en utländsk buske af Ärtväxternas familj, med mycket uppblåsta baljor, hrilken hos oss sällan odlas: Colutea arborescens L. Jag tvekar, om detta föga bekanta namn förtjenar upptagas.

\section{+ Blåtistel = Blåeld.}

Blåtry, se Try.

+ Blåtåtel, se Blåslok.

Bläcken, n., en på våta ställen växande ört, närmast förvandt med Bitterväxterna, men lätt skild genom sina tredelade blad och inuti håriga, rödletta blommor: Menyanthes trifoliata I. Uppgifves af Linné i $F$ l. Svec., n. 173 , vara benämnd Korsbläcker iDalsland, men på det af honom der citerade stället från Vestg. res., s. 234, kallas den Saltbläcker; ovisst derföre, hvilketdera namnet är det rätta. Linné anser denna växt rätteligen böra benämnas Klöfver, men detta namn föres nu allmänt till Trifolium. För öfrigt har Bläcken i nästan hvarje landskap olika benämningar, af hvilka Bockblad. i de södra och Getklöfver i de norra landskapen äro de vanligaste. 
Bläcksvamp, m., ett slägte bland Skifsvamparne, hvars samtliga arter hastigt upplösa sig i en svart, bläcklik vätska: Coprinus Fr.

Bläddrerot, f., slägtet Utricularia L., vattenväxter med hårfint delade, blåsbärande blad, hvilka hålla örten flytande $\mathrm{i}$ vattenytan under blomningen. Blommorna äro tvåläppiga och försedda med endast två ståndare.

\section{+ Bläror, f. pl. = Tarald.}

Bläsa, f., en ettårig, med Molla vanligen förvexlad ört, men närmare beslägtad med Amarant genom sitt fröhus, och lätt känd af sina hvitfläckiga blad. Amarantus Blitum L., nu förd till slägtet Euxolus RAFiN. Jfr Bot. utfl. 2: 113 .

Bo ingår i namnen på en mängd växter af Halkblomstriges familj, såsom Gråbo, Gullbo, Rödbo (nu Binka), Boört. Då alla dessa hafva många små blommor inom gemensam hålk, torde ordet bo här hafva betydelsen mnidus".

† Bockblad, n., ett vanligt växtnamn, men tillagdt de mest skilda växter, t. ex. Bläcken (Skåne), bladen af Konvaljen (Smål.), slägtet Rams ( $P o-$ lygonatum) och Kärleksörten ("Bockebläcken).

Bockhoru, se Brandkorn.

Bockrams, se Rams.

Bockrot, Norrl. = Äng-anis.

Bockskägg, n. 1) De greniga arterna af svampslägtet Clavaria L. 2) Öfversättning. af det Grekiska Tragopogon; detta namn har dock aldrig ingått $i$ allmänna språkbruket, utan den odlade arten af slägtet Tragopogon L. kallas Hafrerot. lilja.

+ Bocksvärd, n., Gotl. = svärds-

Bofis (Tysk. Bofist), m., svampslägtet Bovista (น.), föga skildt från de egentliga Röksvamparne.
Bohon Upas, ett för sina giftiga egenskaper namnkunnigt träd på Java: Antiaris toxicaria LESCHEN.

Bohvete, n., rätteligen Bokhvete, ett bekant sädesslag, som har sitt namn af frukternas likhet med bokallon: Fagopyrum esculentum Мовмон. "Bohvetet gifver bina mera honung än någon annor ört»。 Linnés Sk. resa 97.

Bok, f., det vackraste af våra inhemska löfträd, tillhörande ̊llonträden: Fagus silvatica L. Bildar stora skogar i södra Sverige. Kallas äfven Rödbok, till skilnad från Annboken. Bokens fruktskålar kallas Gjortar, sjelfva frukterna Allon. - I bokens skugga kunna spädare plantor ej uppväxa.

- - i skygd af den-Jummiga boken du hvilar. ADLERBETH 9.

Anm. Med det i bibeln omnämnda bokträdet kan omöjligen förstås vår Bok, hvilken ej växer i Orienten, utan snarare en art Ek, liksom det Grek. y en art af detta träd.

Bolltistel, m., en tistelväxt med i klotform samlade blommor, omgifna af eget blomfoder: Echinops sphcerocephalus $\mathrm{L}$. Kallas äfven Tistelboll.

Bolmrot, f., Vesterg. = Sprängört.

Bolmvixter, en talrik familj bland Tråhjertbladsväxterna, med fem ståndare, fästa på den sambladiga, régelbundna kronan, och tvårummig frukt, dels fröhus, dels bär: Solanacea Juss. De flesta af hithörande växter äro narkotiska och giftiga, såsom Bolmört, Tobak, Spikklubba, Dvalbär ( $A$ tropa).

Bolmört, f., en allmän, giftig, stinkande, klibbig ört med smutsgula, inuti mörkådriga blommor: Hyoscyumus niger $\mathbf{L}$. Rötterna likna Palsternackors, hvaraf örten äfven' benämnes Vild Palsternacka. Som Bolmörtens rötter äro mycket giftiga, måste de noga skiljas från Palsternackans.

Bomull (Tysk. Baumwolle), f., en hvit, mjuk, trådig ludd, som omgifver 
fröna hos arterna af Bomullsslägtet: Gossypium L. Af detta slägte finnas flern arter med-dels trädstam och dels örtstam.

\section{borre. \\ $\div$ Bomullstistel, Nerike $=$ Tistel-}

Bondtobak, se Tobak.

Bonässla, f., en kring hus och byar växande ört af Sugeväxternas familj, vanligen förd till Leonurus $\mathrm{L}$., men enligt folkspråket rättare tillhörande $\mathrm{Bal}$ lota L., hvilken skiljes från den förra genom hjertlika, endast siggade blad. Ballota ruderalis Sw.

$\div$ Borst, $m$. Så benämnas i allmogespråket flera gräs med borstlika blad, t. ex. Stagg (Finnborst, Ängborst), Sandborst (Borstgräs, Borsttitel) $\mathrm{m}$. fl.

Borste, m., en i Dalsland och flera andra landskap bruklig benämning på Borst-tisteln; men vanligen tillägges ett epitet, såsom Brudborste (Smål.), Gullborste (Jemtl.). Ordetborste ingår tillika i både slägtnamn, t.ex. Gullborste (Linosyris vulgaris Dec.), Ringborste, och artnamn, t. ex. Borstnäglika.

Borstgräs, n., ett grässlägte med mycket långa agnborster: Stipa $\mathrm{L}$. Vår inhemska art, S. pennata L., se Fjäderborstgräs.

Borstnate, se Nate.

Borstnäglika, se Näglika.

Borst-tistel, se Tistel.

Borst-tåg, se Tåg.

$\div$ Bosört, Blek. = Besksöta.

Boväxter, Blomhålksväxter med talrika pipiga, femdelade blommor i disken och vanligen utdragna, tunglika blommor i kanten, samt med mjuka hålleg Gill: Corymbiferce Juss.

ligurt, f., ett i Helsingland brukligt namn på Korsörten (Senecio vulgaris L.), hvilket antagits som slägtnamn för Senecio. Jfr Korsört, Stånds.
Brake, Brakved, äfven Bråke och Bråkbuske, m., en på fuktiga ställen växande buske, snarlik Al, men med fullständiga blommor och svarta bär (af äldre förf. kallad Svart-al) : Rhamnus Frangula L. Frukten benämnes Brågon. - Brakved torde vara öfversättning af Frangula. - Namnet är brukligt endast i Svea rike; i Göta rike kallas växten allmänt och lämpligare Tröske.

† Brake, m., Gotl. = Mjödört.

Anm. Detta namn (liksom flera andra på Gotland nationaliserade) är synnerligen märkvärdigt, emedan derigenom tydes det hos abbedissan Hildegard förekommande Brachourz, hvilket Tyske språkforskare ej kunuat bestïmma.

Brambär, se Bringbär.

Brand, m., ett svart, kimröklilt doft, tillhörande svampslägtet Ustilago Bıтн.; utbildas hos vissa växter, före'trädesvis i fröredningsorganerna, hvilka den förstör, t. ex. Fiblebranden på Kornfiblan, Hafreroten m. fl. Skadligast är

Brand i säd, hvaraf man har två skilda arter: 1). Sotbrand, äfven Sot, Sotax kallad (Ust. Segetum $\left.\mathrm{Fr}_{\mathrm{r} .}\right)$, hvilken angriper sädesslagens (utom Rigens) frön, äfvensom flera vilda gräsarters, och, sedan den tunna omgifvande hinnan 'brustit, utbreder sig som ett sotlikt doft. 2) Kolbrand (Ust. Caries Deo.), hvilken hemsöker Hvetearterna och uppfyller det missbildade kornet med en i början svartbrun, fetaktig massa, men sedan öfvergår till ett fint, torrt, stinkande pulver, utan att fröet sönderspiränges.

Brandkorn, n., ett missbildadt sädeskorn, vanligast p̊̊ Rågen, men äfven förekommande på vilda gräs; utväxer till en svart, hornlik massa, allmänt känd ander namn af Mjöldryga, Mjölöka, Bockhorn, Hungerkorn eller Korntagg $m$. fl, och hvilken är ganska giftig: Spermoedia Cla- 
vus $\mathrm{F}_{\mathrm{R}} . \mathrm{I}$ bibeln räknas den till landsplågor: Amos 4: 9; Haggai 2: 18 .

\section{Brandrost, se Rost.}

\section{Braxenblomster, se Bräsma.}

Braxengräs, n., en under vatten växande Groddtrådsväxt, med syl-lika blad, närmast förvandt med Bräkenväxterna: Isoëtes lacustris $\mathrm{L}$. - Braxnen anses under lektiden från sjöbottnen upprota Braxengräset, som då flyter upp på vattnet. Se Linnés Fl. Svec. n. 951.

$\div$ Bredkrasse, $\mathrm{m}$. $=$ Bitterkrasse. Namnet är en mindre passande öfversättning af Lepidium latifolium $\mathrm{L}$.

$\div$ Bremle, Skåne = Lingonris.

Bresilja, f., ett färgstoft, som erhålles af flera Amerikanska trädslag: Röd Bresilja, äfven Fernbock kallad, fås af Cesalpinia echinata LAss., m. fl.; Blå Bresilja, äfven kallad Kampesch, bekommes af Hamatoxylon campechianum L.; Gul Bresilja, se Gelbholz. Af Bresiljan säges Brasilien erhållit sitt namn. ?

Bresil! och du, Kampesch! kring edra vikar sträckt,

Den färgträdsskog, som än på silkets väfda drägt

Med sina spånors saft dess ritningar bestrålar

Och än palatsens golf i mosaiker målar. OXENSTJERNA 2: 132 .

Anm. Ofvan anförda, såsom färgstoft allmänt kända benämningar har jag ansett nödigt att upptaga; men deremot har jag icke funnit lämpligt att antaga Svenska namn på de trädslag, af hvilka de förmodas vara erhållna, emedan dessa icke kunna växa i Sverige.

Bringbår, n, Vesterg. och flerstädes $=$ Hallon.

Anm. Namnets hänsyftning är omtvistad; Wahlenberg anser det rätteligen vara Brinkbär. Snarare bör det (såsom i Vermland) vara Brinnbär, i likhet med det Jemtländska Brännbär, emedan Hallon bäst frodas på svedjeland; men snarast skulle jag vilja antaga, att det är förrandt med Brambär, Brombär, Brumbär. Ett orätt uttal eller en felaktig uppteckning är Hingbär.
Britæ lök, se Sankt Britæ lök. Brombär, se Bringbär.

Brosklaf, se Laf.

$\div$ Brud och Brudgum $=$ Fårkummer.

Brudborste, Smål. = Borst-tistel.

Brudbröd, n., en art af slägtet Spirea, med mycket sammansatta, findelade blad, hvita blomvippor, söta, ätliga rotknölar: Spireea Filipendula L. Kallas äfven Svinbröd, Svinkrässla, Galteknapp, Somilla m. fll.

Anm. I Linnés Sk. resa, s. 238, anföres ett märkligt exempel på växtnamnens förvexling i folkspråket. I en trakt af Skåne, der Konvaljen ej växte, hade man öfverfört detta namn till Brudbrödet, ehuru ej den aflägsnaste likhet finnes mellan dessa växter.

$\div$ Brudgran = Brudsporre.

+ Brudgum-pors, Blek. = Loppört.

+ Brudgumsknappar, Smål. = Åkervädd.

+ Brudljus, Blek. = Flugsporreblomma.

Brudspor're, m., i allmogespråket Brudgran, prydliga växter af Nosseväxternas familj, med röda blommor, som hafva långa sporrar i ett ax: Gymnadenia $\mathrm{R} . \mathrm{Br}$. ört.

+ Brudtrål, m.= Brännande Pil-

Brumbår, se Bringbär.

Brumvåxter, 'I'våhjertbladsväxter med fem kronblad, talrika på fodret fästa ståudare, och småfrukter: familjen Senticosce L. Hit, höra Hallon, Nypon, Smultron m. fl. Namnet härledes af det fornnordiska ordet brum (blad, löf), emedan frukterna vanligen sitta bland bladen.

\section{Brunliven, se Hven.}

Brunkulla, f., en mest i Jemtland växande art af Nossefamiljen, skild från alla öfriga arter genom sina svartbruna blomax: Nigritella angustifolia 
Rror. - Enligt Wahlenberg benämnes den äfven Brunstolar.

+ Brunrot, ett i tredje uppl. af Liljeblads Flora genom tryckfel tillkommet, sedermera af Dalin upptaget namn, i stället för Bunrot.

Brunskära, f., ett slägte bland Boväxterna, från alla skildt genom $2-4$ sträfva borster å fruktens spets: $\boldsymbol{B} i$ dens L. Arterna af Brunskära växa på våta ställen och äro bekanta färgväxter.

Brunört, f., äfven Bruntuppor, f. pl, en lågväxt ört med bruna ax, tillhörande Sugeväxterna: Prunella vulgaris L. I Dalarne lär det senare namnet tilläggas Geranium silvaticum L.; säkerligen af misstag, då ingen anledning dertill finnes hos detta slägte.

$\div$ Brygger, Brygdtnppor, f. pl. (Dalarne.) Detta namn tyckes vid första påseendet afse växtens användande som Humle, helst den i nämnda landskap tillika kallas Backhumle; men emedan namnet är allmännare brukligt på Jutland och der förekommer äfven i sammansättningar, t. ex. Gedebrygger, Smörbrygger, torde för det samma hafva funnits ett gammalt, nu förloradt stamord.

† Brågon, Bråke, Bråkbuske, se Brake.

† Bråssor, Brässor, f. pl., Dalsland $=$ Röllika. Namnet är, enligt uppgift, härledt af det fornnordiska bregda, skifta färg, och skulle således motsvara - rödleka.

Bräcka, f., ett artrikt örtslägte, med fem kronblad, tio ståndare och två nedtill sammanväxta, i spetsen skilda fröhus: Saxifraga L. De flesta arterna äro små fjellväxter, hvarföre endast få erhållit namn $i$ allmänna språkbruket, nemligen:

Bergbräcka, fjellväxt, vanligen kallad Bergdusk. Se detta ord.
Knylbräcka, en allmän art, med hvita blommor och under jorden bildade groddknoppar, i folkspraket benämnd Lärftsblomma: S.granulata L.

Myrbräcka, en i djupa kärr växande art, med gula blommor: S. Hirculus $\mathrm{L}$.

Stenbräcka, en refvigt växande art, med enblommiga skaft och $\nabla a c k r a$ rödblå blommor: S. oppositifolia $\mathrm{L}$.

\section{† Brädspelslilja, se Kronlilja.}

Bråken, n., gemensamma namnet på hela familjen Bräkenväxter, Filices L., Groddtrådsväxter försedda med kärl. Ordet ingår derföre som subjekt $i$ de flesta slägtnamnen. Bräken $i$ sin egentligaste mening är Pteris aquilina L. eller Örnbräken, hvilket så myeket mindre kan kallas Ormbunke som det aldrig växer i bunkar (bunkvis), utan alltid enstaka och just derföre äfven kallas Enstapel efter dess Isländska namn einstqpi.

+ Bränna, f., Smål. = Brännande Pilört.

+ Brånnbår, Jemtl. = Hallon. Jfr Bringbär.

Brännåssla, se Nässla.

† Brånnört, en i Dalins ordbok upptagen felaktig öfversättning af Clematis flammula L., hvilken har sin benämning af den rika, liksom lågande vippan. Växten finnes icke i Sverige och är så föga märkvärdig, att den ej förtjenar eget Svenskt namn. Af slägtet Clematis finnas flera andra, odlade arter, hvilka bäst bibehålla sina Latinska namn.

Bräsma, f., en i Göta rike bruklig benämning på Ångkrasse och så allmänt bekant, att den förtjenar upptagas. - Blommar vid braxnens lektid och kallas derföre äfven Braxenblomster. (Bräsma kommer väl af brasm, såsom braxen kallas i åtskilliga landskapsmål.) 


\section{+ Bråssor, se Bråssor.}

Brödkorgsvamp, m., ett svampslägte med bägarlikt frukthus, i hvars inre ligga talrika rundade platta frukter, likt skorpor i en korg: Cyathus HALL.

Bro̊dträd, n., ett på Söderhafvets öar växande, med Mulbärsträdet beslägtadt träd, af hvars frukter bröd bakas: Artocarpus incisa l. Fin.

$A n m$. Ehuru för oss främmande, är detta träd $i$ resebeskrifningar och eljest - så ofta omtaladt, att det måste upptagas.

+ Brömsar, m. pl. = Brunskära.

+ Bröstbår, bär som erhålles af en i Medelhafsländerna växande buske, Zizyphus vulgaris LAM.

+ Bröstört, Upl. = Hästhofsört.

Brötling, m., en afdelning af Mjölkskiflingarnes slägte, arterna vanligen milda och ätliga: Lactarius volemus $\mathrm{F}_{\mathrm{B} .}, \mathrm{m}$. $\mathrm{Al}$.

Buksvampar kallas sådana, som hafva fröredningen innesluten i sjelfva svampen: Gasteromycetes FR.

\section{Buletång, se Knöltång.}

Bulleblomster, n., en allmän ört af Ranunkelfamiljen, med stora, mångbladiga, boll-lika, gula blommor: Trollius L. - Blomster bortfaller i sammansättningar.

Gullbulle, m., en odlad prydnadsväxt, med brandgula blommor: $T$. asiaticus $\mathrm{L}$.

Ängbulle, en vild art, mèd svafvelgula blommor: $T$. europæeus $\mathbf{L}$.

\section{Bull-laf, se Laf.}

\section{Bullmossa, se Mossa.}

Bunarot, f., äldre benämning på Sprängört (Cicuta L.), hvilket senare namn nu är antaget $\mathrm{i}$ riksspråket.

Bunias, m., af allmogen kallad Bünaris, en mångårig, under förra århundradet $i$ vårt land inkommen Kålväxt, med gula blommor och enfröiga, icke uppspringande skidor: Bunias

$$
\text { Fries, Svenska växtnamnen. }
$$

orientalis L. Är numera det förderfligaste ogräs i mellersta Sreriges östra del.

Anm: Röd Bunias, efter Liljeblad anförd i Dalins ordbok, hör ej till detta slägte, utan dermed menas Cakile maritima, se Marfiol,

+ Bunjeört, _ett i Dalins ordbok upptaget namn för slägtet Bunium $\mathbf{L}$., men då detta växer hvarken vildt eller odladt i Sverige, ej heller kommer hit såsom handelsartikel, måste namnet utgå. Den växt, som hos Dalin afses, tillhör numera ej nämnda slägte, hvarföre benämningen tillika är origtig.

Bunke, m., benämning för växter som växa i tufvor, helst på fuktiga ställen, t. ex.Ormbunke,Tuftåda, större Starrarter (Gotl.) m. fl.

+ Bunkie, m., mindre sötvattensalger (Skåne): Ulva $\mathrm{I}$.

+ Bunrot, Vesterg. = Bönrot.

+ Buris, Dalarne = Gråbo.

千 Burmånner, i stället för Brudmänner, Bohusl. = Hästfibla.

+ Buskmolla, ett i Dalins ordbok upptaget namn, bör utgå. Den ifrågavarande växten (Atriplex portulacoides L.) finnes ej i Sverige.

† Busknäglika, hos Dalin, origtigt namn för Borstnäglika.

\section{Buskviol = Marsviol.}

Buxbom, m., en ständigt grönskande buske (Buxus sempervirens $\mathrm{L}$.), som odlas till infattning af rabatter; är vanligen lågväxt, men uppnår i Skåne flera alnars höjd (se Linnés Sk. resa, 8. $313 \mathrm{~m}$. fl. ställen). - Hos profeten Esaias tages Buxbom som en symbol af trofasthet.

Jag är en frodig buxbomshäck,

Som felar ej att vara täck. V. DALIN 5: 356.

Inom en list af buxbom och grönt

Ritade namn i hundra fasoner. BELLMAN 3: 123.

+ Buxbomsmossa, f. Namnet Buxbaumia L. är gifvet efter en Tysk botanist Buxbaum; det må således icke 
ändras till Buxbomsmossa, hivilket blir absurdt. För öfrigt bör denna högst sällsynta och nästan osynliga mossa ej upptagas i:en ordbok öfver Svenska språket.

† Byll, en förolyckad rådbråkning af det Latinska Bupleurum L., hvilken hvarken botanister eller allmänheten vidkännes.

Bymell, se Mell.

† Bynke, n., se Gråbo.

$\div$ Byttbär = Vikon.

† Byttegräs $=$ Mjödört.

Byttelet, m., ett färgämne, som beredes af lafven Lecangra tartarea. Se Örnlaf.

†. Båtsmanshatt, Båtsmans. mössa $=$ Blåklett (Blåklint).

$\div$ Båtsimän = Knappvädd.

† Bäckblomma, Båckros = 1) Neckros, Blek. 2) Kabbelök, Dalarne.

Bäckböna (äfven Bäckgröna), f. Detta namn har inkommit i skriftspràket efter Beccabunga; men bunga kommer af ett gammalt Tyskt ord bungo (knöl, lök) och har intet att göra med böna. Jfr Punga. - Ifrågavarande växt benämnes rätteligen Bäck-ärenpris.

Bäck-krasse, m.,Cardaminé amara L. Se Ängkrasse.

† Bäcklilja, $f_{.}=$Svärdslilja.

$\div$ Bäcksvärla, Hall. = Svärdslilja. Svärla är sammandragning af Svärdslilja.

Båck-årenpris, se Ärenpris.
+ Bäfregrås $\doteq$ Darrgräs.

Båfverbår, n., en med Stenhallon närförvandt art af slägtet Rubus: $R$. castoreus L.sst. Genom sina röda blommor närma sig Bäfverbären äfven Vikon.

Bägarlaf, se Laf. .

Bälarefror, f. plur., Vesterg. $=$ Backsöta. Troligen rättare Bälg-refvor, som vore ett karakteristiskt namn $i$ anseende till den refviga stjelken och de stora ärtbaljorna.

† Bäljon, Böljon, n., Skåne = Odon.

Bändling, m., sammandr. af Bandtång, en gräslik växt i hafvet: Zoster L. Benämnes ofta Tång, Grästång.

Böna, f., gemensam benämning för åtskilliga Ärtväxter med större, ätliga frön. 1) Bondböna, en art af stora Vickor: Vicia Frıba L., hvaraf Hästböna är en mindre förändring. 2) Turkisk Böna eller Sabelböna (slägtet Phraseolus $\mathrm{L}$.), vanligen med slingrande stjelkar, meu en afart är mycket lågväxt, Krypböna: Ph. nanus $\mathrm{L}$. - Så väl växten som dess frön benämnas bönor. För öfrigt kallas så flere utländska värter, såsom Kakaobönor, Tonkabönor.

Bönrot, f., en i Göta rikes allmogespråk vanlig benämning på roten af Gråbo, Gråböna.

† Böntxäd, så benämnes hos Dalin en i södra Sverige under namn af Gullregn allmänt såsom prydnadsväxt odlad buske. - Benämningen är både olämplig och öfverflödig.
Under denna bokstaf finnes intet Svenskt namn. Alla ur främmande språk lånade, med $C$ begynnande växtnamn, 'hvilka kunna betraktas såsom naturali- serade och numera tillhörande Svenska sprảket, upptagas under $\bar{K}$, då hård $\nabla 0$ kal eller ock konsonant följer på begyunelsebokstafven, hvaremot sådana, som 
icke kunna anses hafva ingått i vårt språk, synas böra bibehållas under $C$, likasom namnen på $\mathrm{Ch}$, t. ex. Champignon, China, och de på $C$ med efterföljande len okal, t. ex. Ceder, C'itron, Cypress. - De tlesta bland här anförda namn böra väl intagas endast $i$ ett Supplement.

Cactus, m., Cacteer, pl., en talrik, i länderna kring Mexikanska viken förekommande växtfamilj, hvars samtliga slägten utgöras af köttiga, saftfulla, bladlösa växtformer, liknande bollar eller stänger. Flera hafva Svenska namn.

$\div$ Cajeputolja, f., som erhålles af trädet Melaleuca Leucadendr'um L., finnes väl upptagen i Svenska Farmakopén, men är så föga bruklig, ingalunda förtjenar anföras i en Svensk ordbok, möjligen blott $\mathrm{i}$ ett Reallexikon.

$\div$ Calaba-balsam, m., som fås af trädet C'alophyllum Calaba L., är ännu mińdre känd än föregående olja och icke ens upptagen i Svenska Farmakopén.

Calabar, extrakt af frön utaf $P h y$ sostigma venenosum BALFOUR, märkvärdigt för dess egenskap att sammandraga ögonpupillen.

Camellia, f., en för sina sköna blommor allmänt $i$ orangerier odlad buske från Japan. Närmast beslägtad med Thebusken.

Caprifolium, m., slingrande buskväxt af slägtet Try, en i trädgårdar vanlig prydnadsväxt från södra. Europa: Lonicera Caprifolium L. Äfven den inhemska, snarlika Lonicera Periclymenum $\mathrm{x}$. odlas under benämning af Svensk Caprifolium, ehuru den har flera inhemska namn. Om aftnarne doftar Caprifolien af vällukt.

- bersån, af blommiga syrener

Och välluktrika caprifolier byggd. STAGNELIUS 1: 404.

Anm. Detta namn, som är rent Latin, synes mig ej böra anföras under bokstafven $K$.

† Caranna-gummi utgår alldeles.
Cardbenedikt (= Carduns bencdictiss), m., en tistelväxt, använd i medicin och så allmänt omnämnd, särdeles i äldre läkareböcker, att den torde förtjena upptagas. Nu Cnicus benedictus G FRTN.

Cascarill, f., barken af flera arter utaf slägtet Croton L., synnerligast af C. Eluteria Sw. från Jamaica, högt värderad i medicin.

\section{Cayenupeppar, se Peppar.}

Ceder, m., ett ädelt och resligt barrträd i Orienten och pâ Atlas-bergen, närmast beslägtadt med vår Tall: Cedrus Libani Loud., Pinus Cedrus I. Kallas i bibeln både Ceder" och Cederträd. - Cedern lemnar ett ypperligt, välluktande timmer.

Cedern lyftade en hjessa,

Och blomman öppnade en barm.

Redan hann sin purpurslöja

Öfver cederskogen höja

Tidens sjette dag. FRANZE் 1: 6 .

Anm. Alla ofriga sammansättningar af Ceder synas mig öfverflödiga, sảsom afseende för oss Svenskar obekanta föremål.

$\div$ Cedrat-citron utgår, såsom varande ett nära obrukligt namn.

Cedro-olja, f., en flygtig olja, som pressas ur citronskal.

† Celaster, m., en buske, som hos oss hvarken växer, planteras eller i handel förekommer, bör väl icke upptagas, helst namnet är oförändradt det Latinskà.

† Centunkel utgår alldeles. Heter på Svenska Knut-arv: Centunculus minimus $\mathrm{L}$.

Chalottenlök, se Lök.

Champignon, m., en mycket läcker och allmänt värderad art af Skifsvamparne, känd genom sina såson, äldre svartbruna skifvor på hattens undre sida: Agaricus campestris I.., m. fl. - Ordet är Franskt och betyder svamp i allmänhet. 
+ Charme, m., är Franska namnet på Anmboken, nu obrukligt, men förekommande hos Linné och äldre skriftställare, dock tillagdt endast den i trädgairdar odlade.

China, f, ett dyrbart, feberfördrifvande medel, som erhålles af flera arter utaf Chinaträdet (Cinchonn L.) från Andernas sluttningar i Peru.

$A n m$. De mångfaldiga olika slag af Chinabarken, som förekomma pi apoteken, kunna icke här upptagas, såsom uteslutande tillhörande farmacevtiska arbeten.

Chinarot, f., en medicinsk drogue, som fås af trädet Smilax China $\omega_{\text {. från }}$ Orienten.

Cikoria, f., en odlad afart af den vilda Vägvårdan, hvars rot begagnas som kaffe-surrogat. Cikoria-kaffe.

Citron, m., frukten af Citronträdet, inhemskt i Orienten, nu allmänt odladt i Medelhafsländerna: Citrus Medicı L.

ILedien skïnker den frukt, hvars sunda och syrliga safter

Hiifta på tungan sin smak. ADLERBETH .75.

Hvad ï citronens varma lund ...

Emot den bygd, der klippans grund

Gür anden kysk och stark?

ATTERBOM 1: 162.

Citronmeliss, m., en i södra Europa vild, hos oss för sin vällùkt odlad art af Sugeväxternas familj: Melissa officinalis $\mathbf{L}$.

Coccionell-lafvar, se Laf. $\div$ Crocus $=$ Saffran. Det är ett rent okynne att begagna Latinska namnet; man kan då lika gerna säga Fagus, Quercus för Bok, Ek.

$\div$ Crotonolja, f., pressas af en art utaf slägtet Croton (C. Tiglium L.), hvilken :användes i medicin.

\section{$\div$ Crucifixort, Dalsland $=$ Kors -} ört.

† Curare, ett häftigt verkande gift från södra Amerika, hvilket anses erhållas af en art Strychnos l.

+ Cymbel, enligt Dalins ordbok Antirrhinum Cymbalaria L., men svårligen skulle någon botanist ana, hvilken växt dermed menas.

Cypergrås, ett vackert och artrikt Halfgrässlägte, med tvåradigt sittande agnskal. En art, Cyperus fuscus L., är inhemsk.

Cypress, m., ett artrikt slägte bland Barrträden, af hvilket i synnerhet en art, såsom en sorgens sinnebild, hos oss odlas: Cupressus sempervirens $\mathbf{L}$.

Ur buskarnes hop cypressen höjer sin spixa.

När jag bärs ur mitt hus ADLERBETH 10.

Och min begrafning firas,

Skall med cypresser siras

Min flaska och mitt krus. C. A. ROTH.

† Cytis, m., buske af Ärtfamiljen, ofta planterad till prydnad: Cytisus I..

Dansande söker ock geten sig Täg till Cytisi blomma. ADLERBETH 15.
Dadelpalm, f., en palmart från norra Afrika, med välsmakande frukter, kallade Dadlar: Phoenix dactylifera L. De i 1 Mos. 43: 11 omtalade dadlar anser maí hafva rarit Pistacier. $\div$ Dagghår, Daggros, Daggört Sileshår.

Daggkåpa, f., se Daggskål.

Daggpil, se Pil. 
Daggskål, f., en allmän ört med breda, veckade blad, i hvilka daggdroppar uppsamlas: Alchemilla vulgaris $\mathrm{L}$. Benämnes ofta Daggkåpa, Jungfru Marie Kåpa, hvaraf bildats det olämpliga namnet Kåpört.

Dagslilja, f. Si kallar Atterbom Convolvulus tricolor $\mathrm{L}$., en art af slägtet Vinda, odlad som prydnadsväxt. Jfr Purpurvinda.

Hvarför klaga, att så kort jag varar, Att jag blommar blott en enda dag? AT'TERBOM 1: 43 .

Dahlsros, f., en allmänt odlad prydnadsväxt af Halkblomstriges familj, med ätliga rotknölar: Dahlia variabilis Desir. Kallas vanligen Dahlia och är benämnd efter en Srensk botanist Dahl. Man eger deraf räl hundra förändringar med egna, flygtiga uamn.

Damascener-ros, se Törnros.

† Dammossa, enligt Dalins ordbok pett slags alg, Byssusn. Namnet är rent af olämpligt, och slägtet Byssus Irrr. har helt och hållet försvunnit.

\section{$\div$ Damspelslilja, se Kronlilja.}

Danskablod, se Mannablod.

$\div$ Dansklöfver, m., ett mindre lämpligt namn på Hedysarum gyrans L., en vid Ganges mynningar växande Ärtväxt (dock vida skild frăn Klöfver), hvars biblad bếfinna sigg i ständig svängning. Växten kan visserligen odlas hos oss i hetaste drifbänkar, men man är bäst betjenad med dess Latinska namn.

Darrgräs, $n$., ett mångårigt gräs med hjertlika, dallrande småax : Briza medic L. Kallas på Franska Amourette, deraf stundom i trädgårdsspråket Kärleksgräs.

$\div$ Degbär, Nyland = Måbär.

Desma, Desmeros, f., en art af slägtet Kattost, med sköna blommor och stark lukt af desma: Malva moschata $\mathrm{L}$.
Desmansknopp, Desmeknopp, m:, en liten af desma luktande vårväxt, med gyttrade gröna blommor: Adoxa Moschatellina L. ( $\mathrm{P} \AA$ Gotland föres detta namn till Honungsblomman.)

$\div$ Desmans-0fris, ett förolyckadt namn, af Liljeblad bildadt i systematiskt intresse, men växten (Ophrys Monorchis L.) är vida skild från Ophrys, och benämningen har aldrig varit antagen.

†Desmegräis = Myskegräs. Namnet tillägges stundom äfven andra starkt luktande växter, t. ex. i Österg. Renfanan, hvars benämning der blifvit öfverförd till Röllikan.

Dill, m., en allmänt odlad kryddväxt af Umbellaternas familj: Anethum graveolens L. Användes som krydda och omtalas redan i bibeln, Matth. 23: 23 .

+ Diptamn, Diptan, ett namn bildadt af det Latinska Dictamnus. Se Nattfackla.

Disksvampar, en stor familj bland Svamparne, med fröredning på öfre sidan, sporerna inom egna hylsor: $D i$ scomycetes Fr.

+ Distron, i. Finland, Upland m. $\mathrm{fl}$. ställen Tistron $=$ Svarta Vinbär.

\section{$\div$ Djefruleus hand, se Herrans} hand.

$\div$ Djefvulsbett, n. (Lat. Morsus diaboli), ett i äldre tider brukadt namn på Knappvädd, men nu föråldradt och obrukligt.

†Djefvulsblod, n., en giftigt brännande nässleart på ön Timor, med hvilken vi Srenskar ingen bekantskap hafva.

Dodra, f. (mångfaldigt vexlande i nttal: Dodder, Dotter, Dåbast, Dåda, Dåde, Dåre, Döra, Döre), ett örtslägte af de Korsblomstriges familj: Camelina Crastz. - En tvåårig, mycket hårig art, Vild-dodra (C. silvestris $\mathrm{W}_{\Delta \mathrm{LLR} .}$ ). 
växer ofta på ouppodlade ställen. En annan, Åkerdodra (C. sativa $\mathrm{F}_{\mathrm{r} .}$ ), växer bland säden och odlas för sina fröns användande i oljeslagerierna. Bekantast är Lindodra (C. foetida $\left.\mathrm{F}_{\mathrm{r}_{*}}\right)$, med uppblaista skidor, hvilken växer bland linet och deraf i folkspraiket fatt namnet Lindotter.

Dosta, f., äfven Ringdosta, ett slägte bland Sugeväxterna, med blommorna sammandragna i ett hufvud: Clinopodium vulgare L. - Namnet härledes af formnord. pristr, qvast, viska; tusta, sammandragen i en knippa. [Isl. fiustr förekommer i den uppgifna betydelsen hos Björn Haldorson, men icke hos senare ordboksförfattare, såsom Fritzner och Cleasby-Vigfusson. Norska folkspråket har Tust, liten vippa, tofs ; T'usta, knippa (af halm o. d.); tusta, sammanveckla, hoptrassla. Utg. anm.] Jfr Konig.

+ Drabinda, f., en i Skåne och flerstädes bruklig benämning på Åkervinda.

† Dragblad, n., enligt Linné ett i Småland förekommande namn på $\mathrm{Al}$ chemilla vulgaris $\mathrm{L}$. Det synes nu vara utgånget; åtminstone har jag der hört det tilläggas endast Groblad.

Drakblod, n., ett bekant harts, som erhålles af det utländska trädslaget Pterocarpus Draco L., ïfvensom af Calamus Draco WiLLd.

Drakblomma, äfven Drakuos, f., ett inhemskt örtslägte af Sugeväxternas familj, med blå blommor: Drctcocephalum Ruyschiana $\mathrm{L}$.

\section{Droppmossa, se Mossa.}

+ Drufbild, m., en art Mögel: Botrytes دrcu. Detta och en stor mängd andra, rent af mikroskopiska svampars namn, upptagna i Dalins ordbok efter Liljeblads Flora, måste ovilkorligen ntgå.

+ Drufhyacint, $m_{.}=$Perldrufva. Sedan slägtet Muscari MrLz. nu blifvit skildt från Hyacintlus $\mathbf{L}$, eger ifråga- varande, i systematiskt intresse gifna namn icke vidare någon tillämpning.

Dufkulla, f., en vacker hrit skogsblomma af Hvifveväxternas familj, den enda Svenska växt med sjudelad krona och sju ståndare: Trientalis europaca $\mathrm{L}$. Dufkullan, sommarens förste härold, $1 \mathrm{y}$ ser som en stjerna i den dystra skogen.

† Dufkål, Vesterg. = Vägsenap.

+ Duflins, se Lins.

† Dufrảg, m., en olika tillämpad benämning på âtskilliga mossors frögömmen.

†Dufstol, Dufrestol, m. = Blåklett (Blåklint).

$\div$ Dufrefot, m., enligt Wahlenberg Geranium columbinum L.; öfversättning efter Latinet.

† Dufägg, n. $=$ Tarald.

Duggört = Daggskål.

+ Duk-ricin, m., ett alldeles onödigt namn på Ricinus Mappa L. från Ostindien, med hvilken växt Svenskar svårligen komma att göra bekantskap.

Dulcamara $=$ Solanum Dulcamara L., se Besksöta.

† Dunstockar, m. pl., Gotl. = Kafveldun.

Dunört, f., ett artrikt slägte af Kroppväxternas familj, med regelbundna fyrbladiga kronor och atta ståndare: Epilobium L. En art, Luden Dunört (E. hirsutum L.), odlas stundom i trädgârdar som prydnadsväxt.

Durrha, f., Durrhakorn, n., ursprungligen ett Negerfolkens sädesslag: Holcus Sorghum $\mathrm{L}$.

†Duvagräs, efter Wahlenberg C'entunculus minimus x. $_{\text {. Namnet är mig }}$ obekant, och det förekommer icke hos någon annan författare än Wahlenberg.

Dvalbåx = Galnebär (Atropa Belladonna L.).

† Dvalkullor, Valkullor (skrifves vanligen, men orätt Hvalkullor ${ }^{\circ}$, 
f. pl., benämning i Jemtland på Ängbulle. Man plägar om midsommarsnatten lägga växten under hufvudgärden för att försättas i extatisk sömn. (Sannolikt härledes val af dvala.)

Dverg. ett mycket vanligt epitet så väl-till lågväxta arter, t. ex. Dvergbjörk, som till artförändringar, t. ex. Dvergapel.

Dvergmandel, se Mandel.

Dyblad, n., en på vatten flytande växt, med njurlika, skaftade blad och hvita blommor: Hydrocharis Morsus rance $\mathrm{L}$.

Dyborre, m., en under vattnet växande ört, med svärdlika, hvasstandade blad och rosenröda blommor: Stratiotes aloides $\mathrm{L}$. Dyborren. är, enligt Linné, Nordens enda palmartade växt.

\section{Dyfräken, se Fräken.}

Dyfrelsträek, m., ett slags gummiharts, som erhålles ur roten på $\mathrm{Fe}$ ruía Asa foetida L., en Umbellat i Persien.

+ Dymossa utgår, liksom öfriga endast $\mathrm{i}$ systematiskt intresse bildade namn på mossor böra utgå, helst de aldrig komma att urskiljas af allmänheten och ej heller begagnas af botanister.

+ Dyuaman, m. (se Linnés Sk. resa 148) = Kafveldun.

† Dynaskråppa, f., Skåne. En mycket storväxt art af slägtet Syra, med ganska smala blad: Rumex Hydrolapathum Huds.

+Dyplanta, f. $=$ Äfjebrodd.

Dån, m., örtslägtet Galeopsis L., tillhörande Sugeväxternas familj, skildt från de öfriga genom trenne frăn kronans nedre läpp uppskjutande tänder. De flesta arter hafva stickande hår, synnerligast Hampdånen (G. versicolor Curr.) med stora blommor, till färgen gula, utom den nedre läppen, som är mörkröd. För dessa hårs skull kallas de i folkspråket Nässlor. (Nässla heter, enligt Dioscorides, på Dakiska språket ivv.)

\section{Dårrepe, se Repe.}

+ Dåska, f., Skåne = Lin-snarrefva. - Namnet är sannolikt härledt från Dodra, hvilken benämning i Engelskan (Dodder) öfverföres till Cuscuta.
Ebenholz, m., utmärkt hårda trädslag från Orienten, som användas till finare snickar-arbeten, förnämligast Svarta Ebenholzen, hvilken erhålles af Diospyros Ebenum L. ғп. Omtalas ofta i bibeln, under namn af $H e b e n t r a ̈$, såsom en dyrbar handelsvara från Ofir.

$$
\text { Blott Indien alstrar }
$$

Ebenholz; hos Sabeerna blott gror rökelsebusken.

$\div$ Eckergräs, se Äckergräs. ADLERBETH 75.

+ Efsing $=$ Äzing.
Ek, f., ett allmänt bekant träd af Ållonträdeñs familj: Quercus Robur L. Frukten kallas Ållon, i vissa landsorter Akarne (af Isl. akarn). Eken är våra skogars"ädlaste, hårdaste trädslag.

Eken i sin höghet stolt, och hedrad i sitt fall,

Han(!) skogens konung (!) rar, och böljans blifra skall. OXENSTJERXA 2: 93.

I Djurgårds-ekar, susen ränligt öfrer Den störste sångarns bild, som Norden bar! TEGNÉR 3: 215. 
Se ekens strid mot stormarne pa fjellen. STAGXELIUS 2: 184.

(Obs. Eken växer ej på fjellen.)

Anm. I Orienten finnas mångfaldiga skilda arter af $\mathrm{Ek}$, så att den $\mathrm{i}$ bibeln omtalade troligen är ell annan art än vår. nJag uträckte mina grenar såsom en ekn. Syr, 24: 22 .

- Ekebräken, n., en art af slägtet Stensöta, med tre gånger pardelade blad: Polypodium Dryopteris L.

\section{Ekefock, se Fock.}

Eknas, m., se Kornell. - Detta i Vesterg. brukliga namn är så bestämdt och egendomligt, att det förtjenar upptagas.

Ekorrbär, n., en med Konvaljen närbeslägtad ört, tillhörande Liljeväxterna, med tvenne hjertlika blad på stjelken: Convallaria bifolia L. Smilacina DesF.

Ekorrsvamp, m., en art af Buksvamparnes familj, använd i Dalarne som lockbete för ekorrar: Octaviana variegata $\mathrm{V}_{\text {IтT. }}$.

$$
\text { † Eksuga, f., Skåne = Ängs- }
$$
kovall.

† Ekört, f., Skåne = Skogs- och troligen äfven Ängs-kovall.

Elfgrås, n., rättare Elfäxing, m., ett gräs med blå ax, växande i ringar: Sesleric cærulea Ans. - nNär detta gräset växer på en mager äng, synes det afmåla en blå ring, den enfaldiga folket trott förorsakas af elfvors dansanden. Linnés öl. resa 66 .

†Elfnäfver, f., föres af Linné rätteligen till Torsklafven (se detta namn), men i Dalins ordbok till Marchantia, hvilken på Svenska kallas Jordlunga.

Elfring, m., har man kallat vissa i ring växande svampar. Benämningen torde förtjena upptagas.

Elfäxing, se Elfgräs.

$\div$ Elgborst, m., Gestrikl.= stagg.

Elggräis, n., Södermanl. = Mjödört. Detta provinsnamn har ingått i riksspråket och synes derföre böra upptagas. - Vid högtider plägar Elg-" gräset för $\sin$ behagliga lukt strös på golfyen $\mathrm{i}$ bondstugorna.

Tiljorna smyckas af elggräsets blad. DAHLGREN 1: 189.

† Elgrams, Elgstjelk, m., Dalsl. $=\mathrm{Kropp}$.

\section{$\div$ Elinsrot, se Alant.}

Elm, se Helm.

Eluaträd, n., är den i Smilland och flerstädes allmänna benämningen på 0lvonbuske. Andra uttal af namnet äro: Illnaträd, enligt Linné i Skåne Illenaträd (Fl. Svec.n. 264) och Ilänaträd, Ilånneträd (Sk. resa 84, 392). Blomflockarne kallas Elnakringlor i anseende till de stora gallblommornas ringar.

En, f., Enbuske, m., en öfver hela landet allmän buske, tillhörande Barrträden: Juniperus communis L. De bärlika kottarne kallas Enbär. nAf enen är allting nyttigt». RETzIUs 1: 342. - Mången gagnar sin bygd, fast stickande och hvass som-enen. - Enbären mogna först tredje året, så att man på samma buske träffiar. omogna, halfmogna och fullmogna; deraf ordstäfvet:

När alla enebär hunnit mogna,

Bli alla flickor gifta och trogna:

Enbärsträd i bibeln afser de stora, trädartade, i Orienten växande arterna af Enslägtet. »Hon (en falsk tunga) är såsom eld i enbärsträin. Psalm. 120: 4.

† Engelsört, f., ett medeltidsnamn pi̊ Qvanne.

Engeltorn (pl. -törnen), n., uttal i allmogespråket af det Franska églantier (äfven uttaladt Neglantyr) $=$ Lukttörne.

\section{Enlaf, se Laf.}

Enstabb, Enstapel, m. (af Isl. einstapi), benämnes Örnbräkenet, emedan.det icke, si̊som Ormbunkarne, växer i tufvor. Se Bräken. 
Eternell, m., namn pâ mycket olika växter, hvilka torkade bibehålla sig oförändrade.

Etternässla, f., se Nässla.

$\div$ Etterört, f. = Gullkrage (Gul Krageblomma).
Ettlijertbladsvaixter, Monoco- tyledonec. Se Hjertbladsväxter. .

Evighetsblomma, -blomster, Svensk öfversättning af Eternell.

Exing, se Äxing.

F.

Fackelros, f., äfven Fackelblomster, =ört, en prydlig, på strän- der växande ört, med purpurröda, i ax sittande blommor/och tolf ståndare: Lythrum Salicaria $\mathbf{L}$.

+ Fackeltistel, m., namn på arter af slägtet Cactus.

$\div$ Fageblomma, f., Gotl. = Hvitsippa.

$\div$ Fallblomster (origtigt Falk"blomster), n., Upl. Sa kallas de vilda arterna af slägtet $V$ almo för deras hastigt affallande foder och kronblad.

† Fallbär, n., Helsingl., enligt annan uppgift troligen rigtigare Fällbär $=$ Hallon.

$\div$ Fans onda bett, enligt Wahlenberg Paris quadrifolia L. (se Ormbär). blomma.

†Fansögon, i folkspråket=0̈gon-

$\div$ Fastlagsris = Påsklaf.

† Fattigmans-tryssel, m., Skåne = Gullkrage (Gul Krageblomma). Namnet är anmärkningsvärdt endast för sin härledning af det Isl. trys, tros (onyttigt affall, skräp). Jfr RIETZ,s.122.

† Faxe, m., Vesterg. = Råglosta.

Feberört, f., hos äldre förf. = Frossört.

† Femfingerört, f., se Fingerört. Namnet förekommer ofta i skriftspråket.
Fenkol, m., en bekant kryddväxt af Umbellaternas familjys som odlas i södra Sverige: Fœniculum officinale Aru. "Fänkål växte här (i Falsterbo) i trädgårdarne mycket frodigt, uthärdade vintrarne, och sådde sig der sjelf - - Hos oss uppe i landet sås Fünkål hvart år och förgås hvar vinter, utan att nảgonsin bära frukt». Linnés Sk. resa 232.

+Fennä, Fånne, Dal. 1) = Fräken; 2) större i kärr växande Starrarter.

Fernbock, m., ett rödt färgstoft, som erhålles af den raspade veden utaf Ccesalpinic brasiliensis $\mathrm{L}$. och andra Vestindiska trädslag. Namnet kommer af Brasilianska provinsen Pernambuco eller Fernambuco. Jfr Bresilja.

+Fes-sopp, m., arterna af svampslägtet Lycoperdon Touns., tillhörande Röksvamparne.

Fetbladsväxter, naturliga familjen Crassulacece DEc., Tråhjertbladsväxter med tjocka, saftiga blad, regelbundna blommor och hornlika, fria småfrukter. Hit höra Fetknopp, Rosenrot, Taklök m. $\mathrm{fl}$.

$\div$ Fetgräs, Fetuacke, Fetört, vexlande benämningar på Tätörten.

Fetknopp, m., ett artrikt örtslägte, med köttiga, saftfulla blad, fem kronblad, tio standare: Sedum L. Utom Kärleksörten, som särskildt upptages, äro följande arter mest kända:

Bitter-fetknopp, allmän på torra ställen: S. acre L. Har bitter smak 
och anses för 'ett medel mot skörbjugg.

Hvit-fetknopp, lätt skild från öfriga genom hvita blommor: $S$. album $\mathrm{l}$.

$\div$ Fetrot, f., enligt Wahlenberg $=$ Vallört.

\section{$\div$ Fet-tistel $=$ Mjölkfibla.}

Fibla, f., Fibleväxter (Cichoriaсесе V'iliz.), en gemensam benämning på alla Blomhålksväxter med utdragna, tunglika blomkronor (mest gula), hvarföre alltid ett epitet tillägges ordet Fibla. För öfrigt har detta namn blifvit öfverfördt äfven till slägtet Hästfibla för den yttre likhetens skull, ehuru dess diskblommor äro pipiga.

Anm. Namnet är mycket gammalt. Isländskan har fifill, m. (således borde det nya ordet snarare vara bildadt fibel än fibla), och ännu pa 1600-talet skref en Svensk författare (Tillandz), obekant med Isländska språket, Fifler, pl.

\section{Fiblebrand, se Brand.}

Fiblespira, f., en med Klofiblan förvandt ört, med hela blad och i klase sittande blomhufvud: Intybus prcemorsus $\mathrm{F}_{\mathrm{r}}$.

Fikon, n., den läckra frukten af Fikonträdet, en i Medelhafsländerna vïrande och hos oss i orangerier odlad art af slägtet Ficus : F. Carica L. - Icke hemtar man... fikon af tistel. MFatth. $7: 16$.

Fikonträdets vïxt och grenars ojemnhet

Förlåts vid fruktens smak och sötmans lju lighet.

OXFNSTJERNA 2: 154

Indiska Fikon, frukten af Cactus Opuntia L.

Fikor, f. pl., Dalsl. = Rlöfver. Hvitfikor, Hvitklöfver; Rödfikor, Rödklöfver, o. s. .v.

Fingerhatt, m., ett prydligt örtslägte af Skeplingsväxternas familj, med stora, snedt klocklika blommor. Varr inhemska, ofta odlade art har purpurröda blommor: Digitalis purpurea

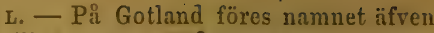
till Allmänna Blåklockan. - Fingerborgsblumma och Fingerborgsört äro öfverflödiga synonymer.

\section{Finger-nunneört, se Nunneört.}

Fingersvamp, m., benämning på upprättstående, köttiga, mycket greniga arter, utan hatt, af slägtet, Clavaria L. Fingersvamparnes grenar aro trinda; flera arter ätliga.

Fingerört, fo, ett artrikt slägte, tillhörande Brumväxterna, med saftlösa frukter, talrika småfrukter utan borst: Potentilla I. Af dess arter hafva Blodrot, Silfverört och Tok sjelfständiga namn. Bland de öfriga förtjena särskildt nämnas:

Femfingerört, Silfverfingerört $(P$. argentea $\mathrm{L}$. .), med upprätt stjelk, alla bladen femfingrade, liksom hos

Refvig Fingerört (P. reptans L.), men hvilken har nedliggande, refvir stjelk.

Vår-fingerört ( $P$. verna L. $)$, med stjelkbladen trefingrade.

\section{+ Finnborst = Stagg.}

Finnbår, n., bären af Haftornsbusken.

Finnkarv, m.; en i Finnmarken väsande Umbellat: Conioselinum Gmelini $F_{n}$. Roten .är aromatisk och har säkert verkande medicinska egenskaper.

\section{$\div$ Finuskägg, n. $=$ stagg.}

\section{Finsk Ingefära, se Mossrot.}

Fiol, f., ett gemensamt uamn pâ flere Korsblomstrige växter med blå eller gredelina blommor: Brukas derföre endast i sammansättningar. Från dessa växter måste noga skiljas, det vidt olika slägtet Viola $\mathrm{L}$.

$A n m$. För att skilja nämnda räxtgrupper skrifver jag Fiol för de förstnämnda och Viol för de senare. Detta öfverensstämmer ock med ranlign uttalet, hvartill kommer; att Fiol är infördt ur Tyskan, men Fiol frản Latinet. 
+Fioringräs, n. $=$ Kryp-hren. Namnet är nyligen infördt $\mathrm{i}$ ekonomiska skrifter.

Fjellbär, n., frukten af en i fjellbygder allmän art af Mjölonris, med årligen affallande blad: Arctostaphylos alpina Sprese.

Fjellklint, m., ett slägte bland Näglikeväxterna, med enblommiga stjelkar och parvis tiotandade, enrummiga fröhus: Wahlbergella Er.

Fjell-ljung, m., en halfbuske, tillhörande Ljungväxterna, liknande Kråkriset, men med ägglika blå blommor: Phyllodoce ccrulea (L。).

† Fjellrapa, $\mathrm{f}_{\mathrm{o}}=$ Dvergbjörk.

Fjellskära, f., en med Ängskäran förvandt ört, men med fjäderlikt fröfjun, på undre sidan hvitludna blad och blå blommor: Saussurea alpina DEC.

Fjellsyra, f., en från örtslägtet Syra nyligen skild art, med två pistiller (de egentliga Syrorna hafva tre): Oxyria digyna (L.). Fjellsyrans blad hafva en ganska behaglig syra.

Fjelltåtel, m., ett med Tåteln närförvandt slägte, men har alla blommorna tvåkönade och glatta blad: Vahlodec atropurpurea $\mathrm{Fr}_{\mathrm{r}}$.

Fjellvicka, f., en fjellväxt af Ärtväxternas familj, parbladig med uddblad utan klänge och med gula blommor: Phaca frigida $\mathbf{L}$.

Fjellvippa, f., en vacker fjellväxt af Brumväxternas familj, med snöhvita, âttabladiga blommor lika Hvitsippans, men med småfrukter liknande Vippornas: Dryas octopetala $\mathrm{L}$.

Fjädergrås, rätteligen Fjäderborstgräis, n., Sveriges utmärktaste grässlag, med mycket lång, fjäderlik borst: Stipa pennata L. Växer endast i Vestergötland.

+ Fjäiderkål och dylika endast i högre trädgårdsspråket brukliga be- nämningar äro otaliga och anses af mig ej förtjena upptagas i en allmän ordbok öfver Svenska språket.

Fjädernäglika, se Näglika.

Fjällnarf, m., ett slägte bland Narfväxterna, skildt från öfriga genom fjäll under de enkelt motsatta bladen: Lepigonum $\mathrm{F}_{\mathrm{R}}$.

Fjällticka, se Ticka.

Fjällört $=$ Vätteros.

Fjärva, f., en på hafsstränder växande ört af Skrufblomstriges familj, med isgrå, liksom af rimfrost öfverdragna blad, hvarför den i Norge äfven benämnes Hilsko (af Isl. héla, rimfrost): Stenhammaria maritima REIOH. - Namnet Fjärva är egentligen lånadt från Norskan (fjera, strand, strandbräłd). Jfr Hilsko.

Flen, m., Flengrås, n., ett frodigt gräs, liknande Rör, växande på våta ställen: Digraphis arundinacea Trix. Benämnes äfven Fläck, Rörfläck (Rörflok, enligt Wahlenberg). Flenen är ett ypperligt, mycket gifvande fodergräs.

\section{Flenkampe, se Kampe.}

Flenört, f., en allmän, stinkande ört af Skeplingsväxternas familj, med knöliga rötter, hjertlika blad: Scrophularia nodosci L. - Genom förvexling har namnet i Vesterbotten blifvit öfverfördt till skelörten och Röllikan.

†Flockört benämnes i Dalins ordbok slägtet Caucalis $\mathrm{l}$., men namnet är obrukligt och dessutom obehöfligt, ty ingen art är inhemsk eller i något afseende utmärkt.

\section{+ Flohår $=$ Hornserf.}

Floks, m., en ört af de Hålkblomstriges familj, med blad liknande Hampans och med röda blommor: Eupatorium sannabinum L. - Liljeblad kallar växten Flåckel; men Floks (som torde härleda sig frîn Isl. flóki, flock,

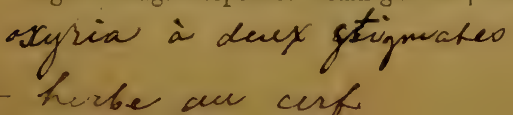


tâtt, tofs) är det i folkspråket brukliga namnet.

Flotagrås, n., en art af slägtet Igelknopp, med mycket linga, smala, pa rattuet flytande blad: Sparganium natans $\mathrm{L}$. "Flotgräs... flöt med ändarne af bladen, och under starkaste stormen bröt så vågorna, att vattnet stod helt spegelklart så långt detta gräset växten. Linnés Vestg. resa 263. - „Han mår som ko i flotagräs», Smảländskt ordspråk om en som har allt fullt opp. Jfr Linnés Fl. Lapp. p. 273.

Flugblomma, f., en till Nosseväxterna hörande ört, hvars mörka blommor likna flugor: Ophrys Myodes (L.). "Dess blommor äro så lika flugor, att en okunnog, som får henne se, skulle tro, att 2 eller 3 flugor sutto på stjelken”. Linnés 01 . resa 45 .

Flugblomster, rätteligen, Flugsporreblomma, f., en art af slägtet Sporreblomma, med blad liknande Linets och gula blommor med lång sporre: Linaria vulgaris Hrz. - Med flugblomster lagda i mjölk dödar man flugor.

$\div$ Flugfånga, f. $=$ Tjärblomster. Obrukligt namn.

$\div$ Fluglin, n. Hvad dermed menas är mig obekant; troligen Flugblomster.

\section{Flugsporreblomma, se Flug- blomster.}

Flugsvamp, m., en utmärkt vacker svamp med röd hatt, beströdd med hvita vårtor, för öfrigt hvit: Agaricus muscarius L. Man har en stor mängd arter, som föras till samma slïgte. Flugsvampen är i hög grad giftig.

† Flugträd, en : benämning på Svartpoppeln då dess blad vanställas af insektlon.

Flyghafre, $m$., en vild art af slägtet Hafre, med ludna frön: Avena fatua J. Växer som ogräs bland säden och ïr på många orter en verklig landsplåga.

\section{†Flåsgrås, Flåsklöfver = Har- klöfver.}

† Flå, Fläk, se under Flä́gg.

† Fläck, se Flen.

† Fläcklaf, utgår, se Laf.

Fläder, f., rätteligen Fläderhyll, m., en buske af slägtet Hyll, med stora hvita blomflockar: Sambucus nigra L. „Fläderns blommor med sin lukt besvära och förorsaka hufvudvärk hos många. Ganska osundt är det ock att sofva, iliven i fria luften, nüra blommande flädern. RETZIUS 2: 647 .

Fly en sjuklig sömn, hvars anda kring din bygd

På luften sänker sig i fläderblommans skygd. OXENSTJERNA 2: 122.

Fläderväxter, Tvåhjertbladsväxter med ståndare fästa på den sambladiga kronan of fan det trerummiga fruktämnet, mod trenne märken: $V a-$ lerianece DEC.

Flägg, m., ett i Skåne (äfren Danmark och England) vanligt namn för de svärdlika bladen på Kalmus och Svärdsliljan. I Linnés Sk, resa, s. 359, kallas den senare Fläje; men s. 365 säges: "Calmus, som mycket växte vid Vrams kyrka, kallades Flägg, och icke Iris, dem bönderna på åtskilliga ställen blandat till namnetn. Men äfren $G l_{y}$ ceria a quatica WАнц. kallas Fläjegräs, och otvifvelaktigt är den Norrländska benämningen Flä, Fläk på de upprätta arterna af slägtet Tgelknopp samma ord.

Flätting, m. 1) = Gumrik-korn; 2) ett slägte bland Halfgräsen, med sammansatta, flattryekta ax: Blysmus PAxz.

† Fnockväf, m., ett mikroskopiskt svampslägte. Utgîr alldeles.

Fnösksvamp, m., rättare Fuösk: ticka, en pii triidstammar (af Bok och Björk) växande trähård stamp, af hvars inre, lösare massa fnöske beredes: $P_{0}-$ lyporus fomentarius $\mathrm{Fr}_{\mathrm{r}}$ - Före tïndstickornas upptäckt var fnösksvampen af stïrsta vigt.

Fock, m., gemensamt namn på svampslägtena Deedalea och Trametes, 
liknande Tickorná, men med större, oregelbundna porer. De mest bekanta arterna äro:

Ekefock, trähård: Dcedalea quercina PErs.

Sällefock (Helsingl.), utmärkt för sin vällukt: Trametes suaveolens $\mathrm{Fr}$.

\section{Foderbeta, se Beta.}

Foderbräken, n., ett slägte bland Bräkenväxterna, växande i form af strutar, med från örtbladen skilda fruktblad: Struthiopteris germanica WiLLD.

Fodersmäre, se Smäre. losta.

Fodersvingellosta, se Svingel-

Fodervicka, se Vicka.

Fogelarv, m., en liten ettårig ört af Narfräxternas familj, med tre ståndare: Holosteum umbellatum $\mathrm{L}$. Fogelarven är en af de tidigaste vårväxter, hrilken hastigt afblomstrar och försvinner.

† Fogelbo, n., kan väl aldrig anrändas som växtnamn, men tillägges af Wahlenberg den vilda Morroten.

Fogelbär, Fogelkörs, se Körs. Fogelhir's $=$ Hönshirs.

Fogellim, n., egentligen lim kokadt af Misteln, men tillägges såsom namri stundom sjelfva busken.

\section{Fogelvicka $=$ Kråkvicka.}

Fogelört, f. 1) En art af slägtet Slideknä, med små blommor i bladvecken: Polygonum aviculare L. 2) Namnet tillägges i Österg. örtslägtet Jungfrulin.

\section{Fredagsbjörk = Dvergbjörk.}

+ Fredlös, ett gammalt, nu utgringet namn på Frossört; troligen förvridet.

Frier, f. (?), ett örtslägte bland Skeplingsväxterna, med gapande blommor och öfre läppen hoptryckt: Pedicularis $\mathrm{L}$. . - Namnet är mycket gam- malt (Isl. frer, n. pl., Mösog. frius, frost, köld), nu vanligen öfversatt med Kallgräs, dock icke utdödt i folkspråket. - Utom Kung Carls spira (som särskildt upptages) och flera fjellörter äro följande tvenne arter allmännare kända:

Kärrfrier, med upptill grenig stjelk: $P$. palustris $\mathrm{L}$. Kallas äfven Lievarg i folkspråket.

Skogsfrier, äfven Granfrier (Wahlenberg), endast vid roten grenig: $P$, silvatica L. Benämnes i folkspråket också Grangräs, Granört.

+ Frillogräs, se slägfrid.

+ Frimodig bénämnes Konig en- n ligt Wahlenberg.

Fromental, m., det i förra seklet allmänt brukliga namnet på Knylhafre, nu utgånget, men förekommande i Linnés och Retzii skrifter samt i äldre hushållsböcker.

Den höga Fromental, som härmar hafrens topp

Och, liksom skrytande med dubbla skördars hopp,

Som gräs hör ängen till, med ax är åkren egnad. OXEXSTJERNA 2: 30.

Frossört, f., namñ på mångåriga örter, tillhörande Sugeväxterna, med trenne $\mathrm{i}$ bladvecken parvis sittande blå blommor: Scutellaria L. - Allmänna Frossörten: S. galericulata $\mathrm{L}$.

Fruekål,m.=Slåtterfibla. nLandtmannen brukar här neder på åtskilliga ställen, besynnerligen vid slåttertiden, att samla bladerna, som då äro'störst, samt kika och äta dem alldeles som kål». Linnés. Sk. resa 25.

Fryle, m., ett slägte bland Tågväxterna, lätt skildt genom sina gräslika blad: Luzula Deo. Blommar tidigt om våren. - I vissa orter öfverföres namnet till spergeln.

Fräken, äfven Fräkne, n., ett egendomligt slägte, tillhörande Groddtradsväxterna, med pipiga, ledade, bladlösa stjelkar, men oftast mycket gre- 
niga: Equisetum L. Fräkenvärterna ntgöra en medelform mellan Bräken och Barrträd. Af misstag benämnes Bräken stundom för Fräken. - Liksom af sjunkna kontinenter endast bergstopparne återstå såsom låga öar, så àterstå nu af fornverldens fräkenskogar endast lågväxta plantor. - Fräken-arterna hafva talrika namn i folkspråket, hvarför här måste upptagas:

Dyfräken (E. limoșım L.) med enpipig stjelk.

Kärrfräken (E. palustre L.) med flerpipigr stjelk; pii fuktiga ängar.

Skaf-fräken (E. hiemale L.) med sträfva stjelkar utan grenar. Kallas allmänt Skafgräs.

Skogsfräken (E. silvaticum L.) med mysket findelade kransgrenar.

Akerfräken (E. arvense L.) med fruktbärande, enkla, grenlösa, snart vissnande stänglar; de ofruktsamma stänglarne äro greniga.

Ängfräken (E. pratense Eнгн.), likt det näst föregående, men spädare; de fruktbärande stänglarne utskjuta alldeles enkla grenar.

Frikenbottnar benämnas dy fulla träsk och flodbäddar, beväxta med Dyfräken tätt som säden på en åker.

† Friakenträd, ett på Söderhafvets öar växande barrträd, som liknar Fräken: Casuarina equisetifolia Forsr. Namnet är nytt, väl bildadt, men för min del bibehaller jag helst det Latinska namnet på dylika för oss helt främmande växter.

Fränskifling, m., arter af slägtet Skifling, med frän lukt och smak, hvilka anses giftiga: Hebeloma $\mathrm{F}_{\mathrm{r}}$.

† Fröbild, Fröludd, m., mikroskopiska svampar, som ingalunda förtjena upptagas.

$\div$ Fulbom, m., Gotl. = Hyll. Namnet är en förvridning af det Tyska $F$ aulbaum.

Fur, Fura, f. (oblik kasus fur u), ett allmänt bekant, ständigt grönskan- de barrträd med tvenne parvis förenade barr: Pinus silvestris $\mathrm{L}$. Kallas i olika landskapsmål äfven Fåra, Före, Fira. (Jfr Tall.) Frukterna kallas Kottar, i allmogespråket Borrar. "Furen blifver det högsta trädet i Sverige, och det täflar ofta med Eken i åldern. Linnés Vestg. resa 247. - Vid Norums bruk i Vermland räknade Linne år 1746 på en furustock 409 irrsringar. "Jag haller gerna med dem, som tro, att de många masttriin och gamle stockar, som bär i lnndet funnits, böra erkänna den svarta döden eller digerdöden för sin moder; ty då denve utsopat folket, fingo skogarne växa fritt - - detta träd var uppvuxet år 13337 , och de store förskräckelige pester... tyranniserade emellan 1330 oeh 1350n. Ders.

Furan växer opp att pryda heden.

Jarl Angantyr satt än

RUNEBERG 2: 16 .

Uti sin sal af furu. TEGXÉn 1: 96 .

Furgrås,n.,en vattenväxt af Groddtrådsväxterna, med trådlika stjelkar och blad samt klotrunda, ärtlika frukter: Pilularia globulifera L. Se Bot, utfl. 3: 235 .

$\div$ Fustelholz, m.; veden af Rhus v C'olinus L., som färgar orangegult.

† Futteljus, n., Skåne, enligt Lin- $\checkmark$ né. Se Vätteljus.

Fyrling, m., en liten, på våta stäl- $\checkmark$ len växande ört af Fetbladsväxternas familj, med fyrtal i alla blommans delar: Bulliarda aquatica $\mathrm{DEC}$.

Fyrräpling, m., kallas normalt trefingrade blad, när de tillfälligtvis hafva fyra småblad, t. ex. af Bläcken, Klöfver, Harsyra. Benämnas äfven Lyckoblad, emedan de anses betyda framtida lycka. Ordspråk: nde älskande fyrväpling plocka».

$\div$ Fålafötter, m. pl., Vesterg. $=$ Hästhofsört.

Fårgxäis, rätteligen Fårsvingel.

Fårkummer, se Kummer.

+ Fårpungar, m. pl. = Fårkum-

mer.

Fårsvingel, se Svingel. 
† Fårtarmar, m. pl., Upl.= Åkervinda.

Fårticka, se Ticka.

+ Fårtunga, f. = Åkervinda.

Fårtungört, se Tungört.

† Fällbär, se Fallbär.

Fälle, Åkerfälle = Klofibla:

Crepis tectorum L. i Smål. och Österg., dẹr Crepis biennis L. icke växer.

Fäll-laf, se Laf.

Fältgråbo, Fältkrasse, Fältvippa, se Gråbo, Krasse, Vippa.

Fältvådd $=$ Stjernvädd.

† Fänting, m. På hvad grund Liljeblad upptagit detta namn för Såpörten, kan icke inses.

Färgek, Fårgto̊rne, namn, som endast $\mathrm{i}$ ordböcker pläga upptagas för vissa utländska, hos oss aldrig förekommande växter, synas mig böra utgå.

Fårggräs, Färgrot, Fårgträd äro nomina appellativa och icke någon bestämd växt; allmänneligen kallas dock Centaurea Jacea L. Färggräs.

Färgkullor $=$ Letkullor.

Färgmadra, se Madra.

Färgmossa, se Letlaf.

+ Fölsungafötter, m. pl., Dal. = Kabbelök.

Förgåt-mig-ej, f., en symbolisk benämning på Sköna Ögonblomman (Myosotis palustris RoтI). Namnet förekommer första gången hos Tillandz (1683). [Hos andre, icke botaniske förf. träffas det tidigare, t. ex. i ComesII Upläste gyllene tungomils dör eller Alle spruiks och veltskapers örtegirird, tr. 164n). Utg. anm.]

Ögon som förgätmigej. TEGNÉR 2: 16 .

G.

$\div$ Galanga, Galgant, Galgan= rot äro olika benämningar på roten af Alpinia Galanga sw. från Ostindien.

$\div$ Galban, Galbauum, no, en art balsam från Orienten. Erhålles af $\mathrm{Gal}$ banum officinale Dox. Se 2 Mos.30:34; Syr. 24: 21.

Gall-, Gåll- tillägges hanplantan af växter med skilda kön, t. ex. Gallhumle, Gaillhampa.

Gallersvamp, m.,ett mycket märkvärdigt, utländskt svampslägte, med gallerlikt sammanväxta grenar: $\mathrm{Cl} a$ thrus Мrсн.

† Gallgrås, n. = Jordrök.

Galnebår, n. 1) En utländsk, mycket giftig växt af Bolmväxternas familj: Atropa Belladonna L. Planteras stundom hos oss, men fordrar varsamhet; genom bärens förtärande hafva dödsfall inträffat. 2) Hos åtskillige Svenske författare tillägges namnet bären af Solanum Dulcamara L.; i Linnes Sk. resa, s. 269, föres det till bären af Cornus sanguinea L.

+ Galtebröd, n., Galteknapp, $\mathrm{m}$. = Brudbröd.

Gamander, m., ett i äldre skrifter brukligt namn, som uppkommit af det Latinska Chamcedrys. Den äkta Gamandern är Teucrium Chamodrys L., som icke växer i Sverige; men namnet öfverföres hos oss äfven till Veronica Chamcedrys L. Denna är Retzii Gamander, hvilken "icke allenast pryder ängarna med sina vackra blommor, utan är ock en god foderväxt, som icke qväfver gräsen". RetziUs 2: 764 .

Anm. Namnet, infördt från Tyskland, är numera obrukligt, men förekommer så allmänt hos äldre författare, att det 
svårligen kan uteslutas. I folkspråket har det aldrig upptagits.

† Gantora, f., synes vara rätta uttalet af ett i Dalarne mycket förbråkadt namn på Röllikan (Gralentora, Garntora, Gantola). Namnet tillhör icke riksspråket, men torde $\mathrm{i}$ lingvistiskt hänseende vara af intresse, såsom sammansatt af det mystiska ordet gan. Jfr IHRE och RiETz. Jag har en gång $\mathrm{i}$ Småland hört gantora användt som liktydigt med trollknuta. Se Bot. utfl. 2: 116 .

Gasse (sammandragning af Gåshafree), m., benämues i Skåne och på Gotland Råglostan. - Härmed beslägtadt är namnet Gassa-råg (Linnés Sk. resa 78), råg, som uppruxit sjelfsådd, blandad med Gasse.

Anm. Af Liljeblad (se hans Flora, 2 uppl. s. 469) är slägtet Orobus L. benämndt Casse, men detta namn är förkastligt.

\section{Gatkrasse, se Krasse.}

Gegal, m., torde vara rätta uttalet för ett i norra orterna brukligt, men i uttal mycket vexlande namn (Gegål, Gegan, Gegar", Jäger m. fl.) på Aira ccespitosa I. Härledningen är oviss, möjligen af gigel, ojemn (såsom i ngigeltänd"), motsvarande växtens öfriga namn: Tof, Bunke.

† Gelbholz, m., ett gult färgstoft, som erhilles af en Nordamerikansk växt: Maclura tinctoria Dos, beslägtad med Mulbärsträdet. Kallas äfven Gol Bresilja.

† Gentian, f., det Latinska Gentiana, brukas $\mathrm{i}$ apoteksspraket i stället för Stålört. Gentian-vin benämnes äfven Baggsöte-vin.

† Georgin, f., benämnd efter konung Georg III i England, kallas rättare Dahlsros, Dahlia. Af denna allmänt värderade prydnadsväxt har man öfver hundra afarter med egna namn.

† Geranium, n., är det rent Latinska namnet pi̊ Näfva. Det tilliigges egentligen endast de utländska Pelavgonierna, hvilket senare namu bör föredragas, men upptagas blott $\mathrm{i}$ bihang till en Svensk ordbok.

+Getapel, Getbark = Vägtorn. $\div$ Getblad, Getklofving, Getklöfver, Getkål = Bläcken.

+Getmat, m., Nerike = Foderbräken.

$\div$ Getnos, f. $=$ Frossört. Namnet anföres af Retzius, Wahlenberg, Hartman, men är mig veterligen obekant j folkspråket.

+Getpors, m. = Sqvattram. Ett i Upland $\mathrm{m}$. $\mathrm{fl}$. provinser brukligt namn.

Getrams, se Rams.

+ Getrofva, f., Nerike = Foderbräken.

+ Getstabb, m. 1) Vesterg. = Kropp ; 2) Verml.=Bräken: Pteris aquilina $\mathrm{L}$.

Getvåpling, se Väpling.

+ Gibbergräs, n. = Skogsnäfv\&. Namnets betydelse okänd.

+ Giftträd, obestämdt namn på flera giftiga trädslag i de tropiska länderna. Jfr Dalins ordbok.

Gigelsärt, f., benämning på Ärtväxter med gula blommor och mycket olika långa kronblad (jfr derföre i språkligt hänseende gigel uti "gigeltändn). Namnet afser egentligen Lotus comiculatus $\mathrm{L} .$, men är i folkspråket äfren tillagdt Ängsvialen.

+ Giktgräs, n., Verml. enligt Wahlenberg = Linnésört.

+ Giktrot, f.,. enligt Wahlenberg $=$ Karborre.

† Giuseng, m., roten af Panax Ginseng, hvilken i China och på Japau så högt skattas som läkemedel, att den uppväges med lika vigt guld.

Ginst, m., småbuskar af Ärtväxternas familj, med gula blommor, alla 
ståndarne sammanräxta: Genista L. Ginstbuskarne växa bland Ljung, synnerligast i Halland. Vi hafva deraf tre arter:

Färgginst, med släta grenar: $G$. tinctoria $\mathbf{L}$.

Knutginst, med knutiga grenar: G. pilosa L.

Tagg-ginst, med taggiga grenar: G. germanica L.

Den vilda ros sin vällukt göt

Bland ginstens ånga, ljuf och söt.

ARNELL 32.

Gjortar, m. pl., benämning på Bokens fruktskålar, omklädnaden kring dess ållon (månne af gjord; gördel?).

† Glansfrö, n., Sv. Bot. = Stenfrö.

Glasbjörk, se Björk. - I Dalins ordbok återgifves detta namn med $B e-$ tula fragilis, en benämning som ej finnes i hela botaniska litteraturen.

Glasört, f., en ört tillhörande Mollaväxterna, men med fjäll-lika blad och ledade, köttiga grenar: Salicornia herbacea $\mathrm{L}$. Glasörten växer på hafsstränder, och lemnar soda.

Glim, Glimster, m., örtslägtet Silene L. tillhörande Näglikevärterna, skildt från sina slägtingar genom trenne stift. Namnet är lånadt från Norskan, emedan vi icke ega något Svenskt, men är närförwandt med Klint.

Rödglim, en vanligen odlad art, med röda, $i$ en qvast sittande blommor: S. Ar'meria L.

Ängglim, en på torra backar allmän art, med hvita, nickande blommor: $S$. nutans $\mathrm{L}$.

Glis, m., en Umbellat med findelade, glänsande blad: Ethusa Cynapium L. Namnet är mycket gammalt, gemensamt för de Germaniska språken (jfr Ișl. glys, glans). T. Gleisse. Växten benämnes vanligen, men i systematiskt hänseende origtigt, Vildpersilja ; med Persilja har den ingen närmare slägtskap.

Fries, Svenska växtnamnen. $\div$ Gliseblad, n., tillägges stundom den näst föregåendes, men i Skåne rätteligen Konvaljens blad.

+ Glösen, m. Sa benämnes i Linnés Sk. resa, s. 284, Färgginsten.

+ God Henrik kallas i skriftspråket en art af Molla: Chenopodium Bonus Henricus L.; men namnet har ej nedträngt till folkspråket.

\section{+ Golfsvamp $=$ svamp i hus.}

Gor- (Gorr-) tillägges förkrympta former af Tall, Gran: Gortcill, Gorgran.

† Gorbilla, f., svampslägtet Lycogala Mrẹr. Om man klämmer svampen då han är ung, utflyter derifrån en varlik vätska.

† Gortistel, m. = Åkertistel.

+ Gorrälta, f., Dalsl. = 0don.

† Gossen i det gröna, se Adonis. Gotlandsrofra, se Rofva.

Gran, Grän, f., ett allmänt bekant, ständigt grönskande barrträd, med ensamt sittande barr: Abies excelsa Dzo. En odlad Amerikansk art, med plattare, på undre sidan hvita barr, benämnes Silfvergran. - Frukterna kallas, liksom Furens, Kottar eller Borrar.

En lummig gran ur klyften tränger, Som rann för tio åldrar opp.

De gamla granar våren röna, CREUTZ 52.

Som lyser'opp det mörka gröna

Med späda knoppars purpurfjäll. GYLLENBORG 1: 185. Granar på klipporna stå och skyldra med gungande lansar.

DAHLGREN $1: 141$.

Granat-träd, n., ett ständigt grönskande träd, med glänsande löf, närmast beslägtadt med Myrten: Punica Granatum L. Dess frukter, Granatäpplen, likna vanliga äpplen, men hafva helt olika inre byggnad; de äro läckra och svalkande. Af dem pressas ett angenämt vin : Granatvin. Trädet omtalas flerstädes i bibeln; dess ursprungliga hemland är Orienten, men 
det finnes nu planteradt i södra Europa.

\section{$\div$ Granfrier $=$ Skogsfrier.}

† Grangräs, 1) Medelp.=Skogsfräken; 2) Dalsland = Skogsfrier.

$\div$ Granvarg, Granört, Vesterg. och Österg. = \$kogsfrier.

$\div$ Graune, n., Gotl. = Ljung.

Grenmossa, slägtet Bypnum $\mathrm{x}$.

Groblad, ․ (rättare Grodblad, af Isl. grceda, läka, och ofta öfversatt Läkeblad). I inskränktare mening Allmänna Grobladet (Plantago major L.), med breda, glatta blad och smala ax. I vidsträcktare mening hela slägtet Plantago $\mathbf{l}_{\text {.., }}$ utmärkt genom sin fyrklufna, hinnaktiga krona, och hvars flesta arter hafva egna namn i folkspråket.

Kämpegroblad, med breda, ludna blad, aflånga, rödletta ax: $P$. media $\mathrm{L}$. Kallas i folkspråket Kämpar, Slåsskämpar.

Spetsgroblad, med lancettlika, håriga blad, äggrunda, bruna ax: P.lanceolata $\mathrm{L}$.

Suttgroblad, se sutt.

+ Grodblad, $\mathrm{n}_{\mathrm{.}}=$ Dyblad.

Groddtrådsvåxter, växter som ej hafva egentliga blommor och utbildade frön, såsom Hjertbladsväxterna, utan fortplanta sig genom encelliga sporer, hvilka groende förlängas till en tråd: Cryptogama L. Plantce Nemea $\mathrm{F}_{\mathrm{r}}$. Sporerna likna Hjertbladsväxternas fröstoft. Hit höra Bräken, Mossor, Lafvar, Svampar, Alger.

Grodnate, m., ett från Ranunkelslägtet nyligen skildt slägte, $i$ anseende till dess nakna honungsgrop vid kronbladens klo och för dess tvärstrimmiga frukter: Batrachium (DEO.). Kallas Alnate af Retzius m. fl., men är vida skild från den äkta Ålnaten. Se Nate.

+ Grofkorn, en i Dalins ordbok upptagen, men obruklig benämning pâ vanligt Korn.
Grofnate, se Nate. + Groplaf. Utgår.

+ Gropört = Fyrling.

Grusslok, se Slokgräs.

† Grynhufrud, n., mögelslägtet Aspergillus $\mathrm{Hron}_{.}$, men som det aldrig kommer att af allmänheten skiljas fràn . Mögel, är ej skäl att upptaga det.

Gråal, se Arre.

Gråbo, m., f. (?), ett allmänt örtslägte, vanligen med findelade, gråludna blad, tillhörande Boväxterna, men utan strålblommor: Artemisia I. Äfven Malörten tillhör detta slägte. Jfr Bo.

Allmän Gråbo har platta, endast på undre sidan gråludna bladflikar: A. vulgaris $\mathrm{L}$. Kallas vanligen Gråböna, Bönrot, Bunrot, Buris. (I Dalins ordbok uppgifves, att denna växt

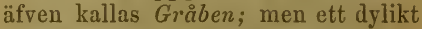
växtnamn har aldrig funnits.)

Fältgråbo har nedliggande stjelkar, trinda, trådsmala, glatta bladflikar: A. campestris L.

Strandgråbo, lik den näst föregående, men med gråludna blad, växande på hafsstränder: A. maritima' $\mathrm{L}$.De båda sistnämnda kallas vanligen Bynke.

+Grån, n., Norrl. = Ljung.

† Gråstarr, se Starr.

Gristenslaf, se Laf.

Gråvide, se vide.

† Grållingshö, Nerike = Ängsvial.

+ Grän, n., Norrl. = Ljung.

Grås, n., den naturligaste och en af de talrikaste växtfamiljerna; tillhör Etthjertbladsväxterna, men skiljer sig från de öfriga och i symnerhet från Halfgräsen genom pipiga, ledade strån; slidomfattande blad, agnlika blommor och hinnbeklädda, mjöliga frön: Graminece Juss. nGräsen i sin simpla drägt utgöra 
här (inom växtriket) allmogen; de äro de meste och skatta mest; berga sig bäst, ehuru de dageligen trampas och plågas». LrxwÉ, Del. nat. 14. - Den gröna gräsmattan, som utgör de nordiska ländernas fägring, saknas i de varma klimaten. Ingenstädes är gräsets grönska lifligare än på Erins gröna ö.

Gräs i vårt gamia språk, likasom i Ioosogötiskan, motsvarade ört i det nuvarande, och ordet bibehåller ännu i allmogespråket denna betydelse $\mathrm{i}$ de flesta växtnamn, hvari det ingår, ehuru det eljest allt mer utbytes mot ört.

$\mathrm{Vi}$ blomstre liksom gräsen

Och vissne lika fort. Psalmb. 16:3.

Gräshafvet (se Dalins ordbok) benämnes rigtigare Sargasso-sjö, emedan det ej bildas af gräs, utan af en art Tång, Sargassum vulgare AG.

† Gräsja, f., Öland = Grästång.

Gräslök, se Lök.

Gräsnate, se Nate.

Grästång $=$ Bändling.

Gröe, m., ett artrikt grässlägte med vippa, mångblommiga, platta småax, utan borst: Poa L. Samtliga arter har Linné namngifvit. Vi upptaga följande :

Berggröe, med platta străn: $P$. compressa $\mathrm{L}$.

Hvitgröe, liten, mjuk, ettårig, mest på odlad jord: $P$. annua $\mathrm{L}$.

Lundgröe, spensligt gräs med lutande vippa: $P$. nemoralis $\mathrm{I}$.

Slåttergröe, Ängsgröe, med trindt, slätt strå, krypande rotskott: P.: pratensis L. och angustifolia L. Är det allmännaste ängsgräs.

Anm. De i Dalins ordbok upptagna arterna Jettegröe, Mannagröe och Sandgröe föras nu till slägtet Glyceria R. Br.

Grönal, se Al.

$\div$ Gröne, n., Norrl. = Ljung.

Grönkulla, f., en med Brunkulla förvandt växt bland Nosseväxterna, med gröna blommor: Coeloglossum viride Harts.

Gronkål, m., kål kokad af vilda växter, såsom Hässlekål, Nässlekål, Fruekål.
Grönpil, se Pil.

Grönvide, se vide.

+ Gubbtänder = Knylvippärt.

+ Guckulin, Guckuråg, frögömmen af större Mossor, företrädesvis Björnmossa.

Guckusko, m., en prydlig växt af Nosseväxternas familj (Cypripedium Calceolus L.), med egendomligt bildade blommor, nedre läppen uppblåst, liknande en väska, hvaraf växten äfven kallas Sorgskräpp (skräppa betyder väska).

Guds hand, se Herrans hand.

† Gulbark, m., Gotl. = Tröske.

† Gulerot, f., i Skåne efter Danskan $=$ Morrot.

Gulhane, m., Jemtl. = Gigelsärt. + Gulliolz, se Gelbholz.

Gulhvifva, se Hvifva.

† Gullbo, Gullgro = både Gullris och Stånds.

Gullborste, m. 1) En på Öland växande ört, tillhörande Boväxterna, med smala, jemnbreda stjelkblad och med gula, $i$ en qrast sittande blomhufvud utan strallblommor: Linosyris vulgaris $\mathrm{DE}_{\mathrm{E}}$. 2) Benämning i Jemtland på Borst-tisteln.

Gullbulle, se Bulleblomster.

† Gulleblomma, f., ett af Gula Krageblommans (Gullkragens) många namn. Se Linnés Sk, resa 251.

Gullfrö, n., tillägges örtslägtet Xanthium L., troligen efter Grekiska namnet; är utmärkt genom sina sträfva blad och två inom blombålken slutna frukter. Benämningen är för denna ört okänd i folkspråket, som deremot hänförer den till Svinmolla.

† Gullgubbar, obestämdt namn, tillagdt flere större Blomhålkśäxter; t. ex. Hästfibla, Slåtterfibla.

Gullhvifva, se Hvifva. 
Gullklöfrer, se Klöfver.

Gullkrage, se Krageblomma.

Gull-laf, se Laf.

Gullpudra, f., en liten, vacker vårvärt, tillhörande Bräckaväxterna, utan kronblad; örtbladen beströdda med ett gult stoft. Chrysosplenium alternifolium $\mathrm{L}$.

Gullregn, n., en vacker buske af Ärtväxternas familj, med långa, hängande, gula blomklasar: Cytisus Laburnum L. Prydnadsväxt, som odlas i södra Sverige, men icke uthärdar Upsalas klimat.

Gullris, ${ }^{7}$., ett särdeles artrikt, i synnerhet Nordamerika tillhörande slägte af Halkblomstriges familj, med rika, gula blomruskor: Solidago L. Allmänna Gullriset (S. Virgaurea L.) är inhemskt och allmänt öfver hela landet. Flera Amerikanska arter odlas som prydnadsväxter, i synnerhet Canadagullriset (S. canadensis $\mathrm{L}_{\text {. }}$ ), som äfven träffas förvildadt.

Gullskålar, f. pl., en vaniig benämning på de större arterna af slägtet solöga.

† Gullspira, f., ett af Liljeblad bildadt namn på Allmänna Videörten.

Gulltraf, m., en frain norra Amerika införd växt af Kroppfamiljen, med stora gula fyrbladiga blommor, hvilken nu är naturaliserad i Sverige: (Enothera biennis L. Har mycket olämpligt blifvit kallad Gul Rapunzel, Gul Nattfiol.

\section{Gullväpling = Gullklöfver.}

Gulmåra, se Måra.

Gulsippa, se Sippa.

Gulskära, f., Vestmanl. en art af slägtet Knoppört: Centaurea Jacea L. Se Jernört.

Gulsuga, f., en ört af Sugevästernas familj, lik Plister, men med gula blommor: Galeobdolon luteum Iluns.
Gulsugan pryder marken i Skånes lundar.

Gulvide, se Vide.

† Gulört, $\mathrm{f}_{\mathrm{o}}=$ A kersenap och Gul

Krageblomma (Gullkrage).

Gummi, n., ett bekant växtämne, som lätt löses $i$ vatten till en slemmig vätska och användes såsom lim. Gummiarterna erhållas af flerfaldiga växter; mest bekant är Gummi arabicum, som fås af Acacia vera och arabica Wrusp. Vår så kallade körsbärs-kåda är äfven en art Gummi.

Gummi gutta, f., ett höggult färgämne, som erhålles af Indiska trädslaget Garcinia Cambogia Dess.

Gummi lacca, f., en fernissa, som fås af flera arter Fikon, t. ex. Ficus indica, bengrlensis $\mathrm{L} . \mathrm{m}$. fl.

Gumrik, Gumring, m., se under Korn.

$\div$ Gumsepungar, $\mathrm{m} . \mathrm{pl}=$ Tarald.

$\div$ Gundelref, $f$. $=$ Murgrön. Benämningen, förekommande hos Bromelius, är lånad från Tyskan, men i detta språk tillhör den Jordrefvan.

Gurka, f., ett artrikt slägte, tillhörande Gurkväxterna, utmärkt af sina klängen : Cucumis L. Hit höra : Allmän Gurka (C. sativus L.), med rätvinkliga bladflikar, sträfva frukter; och Melon (C. Melo L.), med rundade bladflikar.

Gurkmeja, f., ett färgämne, som erhalles af Curcuma longa L., hvilken i Orienten förekommande växt tillhör Kryddliljornas familj.

Gurkväxter, en i varmare länder talrik växtfamilj, utmärkt af sin egendomliga frukt, kallad Gurkfrukt: $\mathrm{Cu}^{-}$ curbitacece u. Endast ett slägte, Hundrofva, är inhemskt hos oss.

Gutta percha, f., den stelnade, elastiska mjöllsaften af Isonandra Gutta Hoor., ett träd på Ostindiska öarna. Allmänt använd till otaliga tekniska ändamål. 
Gyllen, n., ett örtslägte bland Kålväxterna, utmärkt genom fyrkantiga skidor: Erysimum L. Vi ega deraf tvenne arter:

Berggyllen, en tvåårig, på berg och gamla murar växande ört: $E$. hieracifolium $\mathrm{L}$.

Åkergyllen, ett ettårigt åkerogräs : $E$. cheiranthoides 1.

\section{† Gyllenklöfver, Gyllenväp-} ling, m., en hos Franckenius och Tillandz förekommande benämning på "Hepatica nobilis" (Anemone Hepatica L.), men hvilket namn hvarken funnits eller fins i Svenskt språkbruk.

Gyllenlack, m,,ett med Gyllen närförvandt slägte med buskartad stjelk. Blott en art odlas: Cheiranthus Cheiri L. - Jfr Lackfiol.

$\div$ Gårdblomster, ett af okunnighet gifvet namn at Kamillblomman och onödigtvis upptecknadt.

† Gårdgräs, ett obestämat namn, gifvet åt smärre på gårdar växande växter, t. ex, Fogelört, Hvitgröe m. fl. Äfven kalladt Trampgräs.

+ Gårdlök = vårlök.

† Gåsgrås, Smål. = Mannagräs.

+ Gåshafre, se Gasse.

† Gåsört, f. (olämpligt kallad Gåsgräs), en ört af slägtet Hingerört, med parbladiga, på undre sidan hvita blad:
Potentilla Anserina L. Se Linnés Öl. resa 120. - Namnet är bildadt efter Latinet; den uråldriga inhemska benämningen är Silfverört.

\section{Gäddnate, se Nate.}

+ Göingebyxor, f. pl.=Höskallra. Se Linnés Sk. r̦esa 240.

Gökbet, f., Norrl. = Ängfräken.

Gökblod, Gökspott, Gökspy, en röd art af Bladgrus på unga björklöf. Förorsakas af insekter, liksom Galläpplen.

Gökblomma, f. 1) En ört af Näglikefamiljen, med röda, inskurna kronblad, fem pistiller: Lychnis Flos cuculi L. Äfven kallad Gökblomster. - 2) Gotl.= Gulhvifva.

Gökmat, m., en allmän benämning på flere vårväxter, såsom Harsyra, arterna af Vippärt, m. fl.

Gökråg, se Björnmossa. vippa.

† Gökskälla, f., Nerike = Back-

Göksmör,n., Vesterg.= Gigelsärt.

Göksnöre, n. = Backvippa.

$A n m$. Namnet, jemfördt med benämningen Ljungsnöre på Movippan, synes antyda ett fơrloradt namn Snöre för släg. tet Vippa.

† Göksyra = Harsyra.

† Göpon, Vesterg. = Nypon.

\section{$\mathrm{H}$.}

+ Hadd, m., Söderm. = Tuf-ängdun. (Troligen felaktigt för $V a d d$.)

Hafre, m., ett allmänt kändt sädesslag: Avena L., af hvilket flera både odlade och vilda arter förekomma. Bland de förra märkas:

Allmän Hafre: A. sativa $\mathrm{L}$.
Skal-1ös Hafre: A. nuda L.

Turkisk Hafre: A.orientalis ScrrEs., med mera utdragen, ensidig vippa.

Snarlika dessa arter och växande bland säden, men snarare att anse som ogräs, äro :

Flyghafre, särskildt upptagen. 
Purrhafre: A.strigosa Souris., med ensidig vippa.

Bland de vilda, mångåriga arterna är Knylhafre (särskildt anförd) utmärkt som en ypperlig foderväxt. Jfr Fromental.

$\div$ Hafregrås, n. Dermed menas hos Dalin Knylhafre, men namnet bör utgå.

Hafreliatt, m., en svampväxt, som betäcker den afhuggna stubben af Hafre: Sarcopodium avenaceum. $\mathrm{Fr}_{\mathrm{r}}$.

Hafrerot, f., örtslägtet Tragopogon L., tillhörande Fibleväxterna, utmärkt genom en enkel rad af hålkfjäll.

Odlad Hafrerot, med purpurröda blommor: T. porrifolius $\mathrm{L}$.

Vild Hafrerot, med gula blommor: T. pratensis $\mathrm{L}$.

Hafreäxing, m., ett Hafren närförvandt slägte, med vanligen sammandragen axlik blomning: Trisetum Pers. - Gul Hafreäxing ( $T$. flavescens $P$. BEAUv.) är ett godt fodergräs.

† Hafśsräs, n. Sả kallas stundom Bändling. Hänföres alldeles origtigt till Sargasso; se Gräshafvet.

Hafshår, n., åtskilliga i hafvet växande, finare Alger. Till Najas L. kan det ej hänföras.

+ Hafs-kål, m., Alaria esculenta (ธ.), en med Tång beslägtad hafsväxt, men ej tillhörande Sveriges flora och bör ej upptagas i en ordbok öfver Svenska språket.

Hafslin, n., ett bestämdt namn pâ den enkla Conferva Linum L., redan anfördt af Bromelius (s. 32).

\section{Haf-slånga $=$ slånga.}

Hafslök, m., en art af slägtet Scilla L., växande på Englands och södra Europas hafsstränder: S. maritima 1. Användes i medicin, men jag trekar om namnet bör anses tillhöra Svenska språket.
Hafssilke, n., obestämdt namn på finare hafsväxter, snarast Polysiphonia Ao. och Ectocarpus irxas.

Hafsstar', se Starr.

Hafssyra, se syra.

Hafssäf, se Säf.

Hafsvial, se Vial.

Hafsärter, f.pl., Linné=Hafsvial.

Haftorn (pl. -törnen), n., en på mellersta Sveriges kuster växande taggig buske med smala, på undre sidan silfvergrå blad: Hippophaë rhamnoides $\mathrm{L}$. Haftornets bär kallas vanligen Finnbär.

+ Hagebok, ett efter Tyskan bildadt namn på Annbok.

Hagtorn (utan pl.), m., ett allmänt bekant buskslägte af Kärnfruktträden, försedt med tornar: Cratægus L. Man skiljer deraf tvenne arter:

Rund Hagtorn, med rundade, trubbiga blad: C. Oxyacantha $\mathrm{L}$.

Spets-hagtorn, med spetsigt flikiga blad: C. monogyna Jace.

Hagtornen är ypperst till lefvande häckar.

Blickar fram öfver hagtornshecken DAHLGREN 1: 437 .

† Hajtand, f., Bohuslän = Smörblomma.

Halfgriis, n. pl., familjen Cyperacece Juss., tillhörande Etthjertbladsväxterna ; likna gräsen, men hafva oledade strain, ett stift, frön med hårda skal. Hit höra Ag, Starr, Sạf m. fl.

+ Hallborre, m., Wahlenberg $=$ Bitter-fetknopp.

Hallonbuske, m., ett artrikt slägte af Brumväxternas familj, med ätliga, oftast läckra bär (Hallon), sammansatta af flere gyttrade småfrukter: $R u^{-}$ bus L. Arterna, dels buskar, dels örter, hafva sjelfständiga namn och upptagas derför särskildt. Allmänna Hallonbusken ( $R$. idceus 1.o) har röda bär. 
Församlen imera lätt från hallonbuskens höjd

Dess frukt, som bjuder sig, af färg och vällukt röjd.

OXENSTJERNA 2: 53.

De rödaste hallon jag ärnar dig gifva. NICANDER $1: 454$.

\section{Stålört.}

† Halsgräs, n., Herjed.=Allmän

+ Halster, Hilster, Hjelster, i olika landskap förekommande olika uttal af Jolster.

Hampa, f., en för sina tågor allmänt odlad växt, med skilda kön: Cannabis sativa L. Hanplantan kallas Gållhampa, honplantan Fröhampa. Af hampa beredas gröfre väfnader, rep m. $m$.

Anm. Ordet brukas ej i plur., utan nyttjas för sådan användning hampstind.

Hampnässla, se Nässla.

† Hampört, f., rätteligen Hampdån, se Dån. Linnés Sk. resa 272. I Dalins ordbok hänföres namnet till Floks.

+ Handknopp, m., Wahlenberg $=$ Fläckigt Nyckelblomster.

† Hanekam, m. 1) ett i folkspråket alldeles obekant namn på Rhinanthus Crista galli L., af hvilka två sista ord det är en öfversättning; 2) i Skåne benämning på èn art af slägtet Hvifva (? Primula Auricula L.).

\section{+ Hansblomster, se Sankt Hans- blomster.}

+ Hansletsbär, -grås = Nattskatta. Se Linnés Gotl. resa 209.

$\div$ Harbrodd, m. = Fryle.

+ Hardun, n. = Ängdun.

Harfloka, f., en liten Umbellat med hela, jemnbreda blad och enkel blomflock: Bupleurum tenuissimum $\mathbf{L}$.

† Harfot, m. (Hareqvä, Dalsl.), enligt folkspråket och alla äldre författare benämning både på Kattfotsörten och Musörten; men efter uppgift skall vid Nyköping samma namn öfverföras till Ängsyran.
† Hargrås, Skåne = Tuftåda.

$\div$ Hargök, ett alldeles falskt uppgifvet namn.

Harklöfver, se Klöfver.

+ Harkummil, m., Jemtl.=Björnloka. - Ett särdeles opassande namn.

Harkål, m., en· ettårig växt, tillhörande Fibleväxterna, men utmärkt genom saknaden af fröfjun: Lapsana communis L. - Namnet $k$ ål $l$ är mycket olämpligt, men så allmänt antaget, att det måste bibehållas.

Harmynta, f., örtslägtet Calamintha Lasr., förr förenadt med Timjan, men skildt genom i krans sittande blommor. "En art, C. Acinos Clatrv., är inhemsk och kallas äfven Hartimjan.

+ Harpungar, m. pl.= Tarald.

Har-ris, n., en vacker buskväxt af Ärtväxternas familj, med kantiga grenar, gula blommor och håriga fröbaljor: Spartium scoparium $\mathbf{L}$. Harriset växer hos oss endast på de Skånska sandfälten.

Harsyra, f., en vacker vårväxt med enblommig stängel, rotbladen sammansatta af trenne omvändt hjertlika småblad, kronbladen hrita, blåådriga: $O x a-$ lis Acetosella $\mathrm{L}$. Harsyran har en behagligt syrlig smak. Harsyror insamlas i mängd för beredande af oxalsalt.

Hartimjan, se Harmynta.

+ Harull, f. = Ängdun.

+ Harvia, f. (misskrifning för Harvicka) = Kråkvicka.

Harväpling, $m .=1$ ) allmänt Harklöfver; 2) Österb. Harsyra; 3) Sv. Bot. Getväpling.

Haråpple, n., en märkvärdig, underjordisk svamp, som till värtsätt liknar Tryffeln, men inüiti är fyld med svart fröstoft: Elaphomyces NEES.

† Haröra, n., Österb. = Konvaljens blad. 
Hassel, f., Hasselbuske, in., Håssle, n., en allmän, trädartad buske af Allonträdens familj, blommande på , bar qvist: Corylus Avellana L. Frukten kallas Nöt.

Hasselbusken - - -

I vård af slutna skal en oljig kärna bär. OXENSTJERNA 2: 150 .

Hasselört, f., en mångârig, krypande ört med trenne motsatta, njurlika blad och treklufven, inuti brun blomma: Asarum europceum L. Hasselörten växer under hasselbuskar och var fordom eftersökt såsom beredande ett verksamt kräkmedel.

Hatt, m., benämning dels på flere värter med $a$ ) blomhufvud, såsom Blåklett (Båtsmanshatt), Knappvädd (Blåhatt); b) hjelmlik krona, såsom Munkhatt, Stormhatt; dels på den öfre, runda och utbredda delen af Svampar, som fructificera på undre sidan.

Hattsvampar, de fullkomligaste Svamparne, som hafva fröredning på hattens undre sida: Hymenomycetes $\mathrm{F}_{\mathrm{r}}$.

\section{+ Hauter, Gotl., se Höter. \\ Hedelaf, Hedemossa = Islands-} laf.

Hedenblomster, n., en med Kattfotsörten närbeslägtad växt, med gullgula, oförvissneliga blommor: Helichrysum arenarium Moexon. Af Hedenblomstren förgyllas sandfälten i södra Sverige.

Heder, f., en mindre vanlig benämning på Murgrön, efter Latinet: $\mathrm{He}$ dera Helix L. nHedera täckte muren till 15 alnars höjd, såsom en den skönaste tapet, med en beständig grönska». Linnés Sk. resa 99.

$\div$ Helenerot, se Alant.

$\div$ Helgatrefaldighetsblomster, Blek. = Solvända.

$\leftarrow$ Helgeandsört, medeltidsnamn på Qvanne.

$\div$ Helgerefva, f., Wahlenberg $=$ Hundrofva.
Helglö, n., öfversättning af Fr. Sainfoin, en som foderväxt odlad art af örtslägtet Onobrychis Tourx., med ledade fruktbaljor, röda blommor: 0 : sativa LAM.

Helm, äfven Elm, m., af Lat. Elymus = strandråg. Föres mindre rigtigt till Sandröret.

† Helting, hos Liljeblad en förvridning af Lat. Elatine. Utgår alldeles.

Herrans hand, f., ett bland de i folkspråket mycket vexlande namnen på Orchis-arter med handlikt delade rötter, efter medeltidens Palma Christi. Andra namn äro: Guds hand, Jungfru Mariæ hand, Djefvulens hand.

$\div$ Hesperis kan aldrig upptagas som Svenskt namn; vi ega ett allmänt antaget: Nattfiol.

Hexört, f., örtslägtet Circcea L.af Kroppväxternas familj. Samtliga arterna växa i skugga, hafva hjertlika blad och små hvita eller rödletta blommor i klase.

Hilsko, Hillsko, m. Detta namu är af Linné tillagdt Androsace septentrionalis $\mathrm{L}$., en liten ettårig vårväxt af Hvifveväxternas familj, med bladlös stängel, små hvita blommor i en blomflock.

$A n m$. Namnet förekommer för öfrigt icke hos våra författare, ej heller $i$ vårt folkspråk eller i något beslägtadt tungomål, utom Norskan, der det likviil tilllägges en helt annan växt, nemligen Stenhammaria maritima REICH., på hvilken ock namnets härledning från litila (hela), rimfrost, passar mycket väl. Jfr Fjärva.

Himmelskorn, se Korn.

† Himmelskrus, n., en artförändring af Renfana, med krusiga blad. Odlas.

$\div$ Himmelsnyeklar, m.pl.= Gulhvifva.

† Himmels-traf (Himmelsgräs, Himmelsört, Immelört äro olika uttal af samma namn) $=$ Kropp. 
† Hindbär, Hinglaär, Hinnbär, Vesterg., Skåne = Hallon. Synes vara samma namn som Bringbär, Brinnbär. Se Bringbär. - Prior förkastar alldeles den af Ray antagna härledningen från hind.

† Hirkenpirk, Gotl., Pirkum, Skåne. Förvridna namn, af Lat. $H y$ pericum (Johannesknopp, -ört).

Hirs, m., ett i södra Europa, sällan i Sverige odladt sädesslag: Panicum miliaceum L. Enligt Linné höra till detta slägte äfven följande, som nu vanligen äro skilda till egna slägten:

Blodhirs, ett vackert, merendels rödbrunt gräs, med fingerlikt delade ax: Digitaria sanguinalis Soor. och D. humifusa Pens.

- Hönshirs, med grenig, ensidig vippa: Echinochloa Crus galli (L.).

Kafvelhirs, med cylindriskt ax: Setaria P. BEAUV.

$\leftarrow$ Hjernbrylla, f. $=$ Bolmört. Obrukligt namn.

Hjertansfröjd, f., en odlad, synnerligen välluktande art af Mynta: Mentha sativa $\mathrm{L}$. "Hjertansfröjd kallades här (i Vexiö) en Mrenta, som allmänt fins $i$ trädgårdarne, den somlige borgare brukte att sätta med vatten uti ett käril i fönstret, der hon förökte sig mycket... att hela fönstret stod betäckt med en härlig grönska, som både gaf en angenäm lukt och en skön skuggan. Linnés öl. resa 321.

Anm. Namnet Hjertansfröjd tillhör utomlands Melissa I., men hos oss, der Yelissa sällan (i Småland aldrig) odlas, är det öfverfördt till Mentha sativa och än i dag allmänt kändt i Småland. Tillandz, född Småländing, upptager både Melissa och Mentha sativa under namn af Hjertansfröjd. Af anförda ställe hos Linné är klart, att denna är den äkta $M$. sativa, hvilken hos oss förekommer endast odlad eller förvildad. Den är väl känd genom sin på långt håll lätt igenkänneliga sköna lukt och noga skild af hvarje bondgumma i min hembygd, men af botanisterna förvexlas den med en vanlig, vida skild form af Mentha aquatica L. (iH. aquatica $\mathrm{\nabla}$. subsativa Fr.), som redan af vảra äldre botanister, t. ex. Bromelius, rigtigt skildes under namn af Vild Hiertansirojj. - Af ett uppenbart missförstånd har man äfven uppgifvit Hjertansfröjd såsom namn på Konvaljen.

$$
+ \text { Hjertblad, n., Dalsl. = Visil. }
$$

Hjertbladsväxter äro växter med tydliga blommor, utbildade frön, som groende utskjuta från örtbladen skilda hjertblad: Plantee Cotyledonea. De fördelas i Ett- och Tråhjertbladsväxter.

\section{† Hjertbär, n., Upl. = Ekorrbär.}

Hjertstilla, f., äfven Hjertsprẳngsgräs, örtslägtet Leonurus $\mathrm{L}$. bland Sugeväxterna. Vår inhemska art (L. Cardiaca L.) plägar, för bladens likhet med Hampans, i folkspråket äfven kallas Hampnässla, och ett annat namn derpå är Åsknässla (jfr under Nässla); men benämningen Bonässla, som äfven förekommer, föres rigtigare till Ballota (se Bonässla).

+ Hjorthorn, n. = Kråk-krasse. Namnet förekommer hos Franckenius och Tillandz, är äfven anfördt af Wahlenberg, men brukas icke i folkspråket.

Hjortron, n., kallas så väl plantan som frukten af Rubus Chamcemorus I.., bekant för sina välsmakande frukter. Som växten har örtstam, är det af $\mathrm{Da}$ lin bildade namnet Hjortronbuske alldeles orimligt.

Hjortronet... föds i sanka mossars flod. OXENSTJERXA 2: 152.

+Hjortrot, f. = Spenört. Namnet, bildadt efter Tyskan, är ej bekant i folkspråket.

+ Hjorttro̊st, f., en från Tyskan upptagen, i folkspråket okänd benämning på Floks.

Hofsramp, m. 1) svampslägtet Onygena PERs., hvars vanligaste art endast finnes på ruttnade hästhofvar; 2) en ätlig svamp af Skiflingarnes slägte, hvilken framkommer vid löfsprickningen: Agaricus gambosus Fr.

Holt, se Hult. 
Honnugsblomuia, f., en liten ört af Nosseräxternas familj, med blott en rotknöl: Herminium Monorchis R. Br. Anm. Honungsblomster, Honungsgräs äro icke bestämda namn; de tilläggas utan aitskilnad flere växter med söt lnkt, t. ex. Amur, Gulmăra, Ródklöfver $\mathrm{m}$. $\mathrm{fl}$.

Honungsdagg, f. 1) en söt, hlibbig rätska, som efter hastiga temperaturrexlingar utsrettas af rärternas blad; 2) det sötaktiga, groddceller innehållande slem, som afsöndras af MIjöldrygan (Cordyceps purpurea eller Spermoedia Clavus $\mathrm{F}_{\mathrm{E} .}$ ) och ofta betäcker blad och ax hos rågen. - Äfren Linné käade denna, men han förrexlade den med Mjöldaggen (slägtet Erysiphe HeDw. ris.), hvilken han kallade den mjöliga Honungsdaggen, ehuru mellan dem ej finnes ens den allägsnaste förrandtskap. Jfr Vestg. resa 28.

Honungsklöfrer, se Amur.

$\div$ Horbjörk, se Björk. - Ordethor framför vä̃tnamn utmärker: oegentlig, afrikande från den äkta arten.

Horleta, Horletta, f., en ettårig art af slägtet Stenfrö, hrilken är ett ranligt åkerogräs och hrars röda rot kan användas till smink: Lithospermum arvense $\mathbf{L}$. Kallas äfren Sminkrot (Liljeblad, Hartman).

Hornserf, m., ett under vatten rärande örtslägte, med findelade, hornartade blad: Ceratophyllum $\mathrm{L}$.

$\div$ Hornsilke, n., ett alldeles odugligt namn, hvilket bör helt och halllet utgå, dels för sin olämplighet, dels för Tärtens (Scytonema AG.) obetydlighet, som gör att den ej kommer att af allmänheten urskiljas.

\section{Horntistel $=$ Vägtistel.}

Hors- tillsättes flere växters namn sissom artnamn, men omvexlar alltid med Häst-, sâ att det ntan âtskilnad säges än Horsafibla, Horsamynta m. fl., än Hästfibla, Hästmynta 0.s. r. bär.

$\div$ Horsabair, n., Blek.= Hagtorns- $\div$ Horsagriis, n.; Wahlenberg $=$ Stallört.

† Horsamyuta, se Åkermynta.

$\div$ Horskonung, m., Öland=Tulkört. - Namnets mening är srår att fatta; med slägtet Koning har ifrågavarande väst intet gemensamt. Jfr Linnés Öl. resa 125.

\section{Horsljung, se Ljung.}

$\div$ Hostört, f. Namnet är väl ursprungligen en öfversättning af Tussilago, men sedan öfrerfördt äfren till andra växter, såsom Jordrefva, Röllika $\mathrm{m}$. $\mathrm{fl}$.

Hufrudkål, m., en artförändring af Allmãnna Kålen, hvars blad knyta sig tillsammans till ett hufvud. Kallas äfren Hvitkål. - Af samma anledning brukas ock benämningen Hufvudsallat: Lactuca sativa V. capitata $\mathrm{L}$.

$\div$ Huggormsört, f.= Ögonblomma. - Namnet förekommer endast hos äldre författare; men från Dalarne uppgifres Blå Huggormsört såsom benämning på Echium (?).

Hult=, som ingår i flere rärters namn, afser i folkspråket egentligen bokskog, till shilnad frain tallskog, hrilken benämnes blott skog.

†Hultabrälien, n., en art af slägtet Stensöta, med två gånger pardelade blad: Polypodium Phegopteris L. Denna art synes vara den egentliga Träjon, ehuru detta namn är öfverfördt till andra arter.

$\div$ Hultamjella, Holtemjella, f., Dalsland (enligt Linnés Vestg. resa 235). Hultasuga, f., Vestere. = Ängskovall.

$\div$ Hultavira, f., Smål.= Dufkulla. - Namnet härledes snarare af ves än af hvifua. Se Vera.

Huule, m., en så väl rild som odlad slingerväxt, hvilken allmänt anrändes rid bryggd: Humulus Lupulus L. 
Stjelkarne kallas Hummelrefvor, frukthängena Hummelliupor. - Jfr Pors.

Ãn humlen, slingrigt böjd kring smala tallens spröte,

Har $15 \mathrm{ft}$ en' hastig skog ur jordens ljumma sköte.

OXENSTJERNA 2: 26.

$\div$ Humleblomster,

Humlens blomster, men tillägges i Dalsland Fårkummer.

Humlesuga, f., en ört tillhörande Sugevärterna, med sträfra blad och i ett arlikt hufrud sittande mörkröda blommor: Betonica officinalis L. Humlesugan öfrerensstämmer till sina egenskaper med Humlen och har som denne blifrit använd till brygd, menförorsakar, liksom Porsen, ,rrsel.

Hummelbinda, se Binda.

$\div$ Hummeltuppor, f. pl., Medelpad = Kråk-klöfver.

$\div$ Hundatand, fo, enligt Wahlenberg $=$ Kråk-krasse. Namnet obrukligt.

$\div$ Hundbär, n., Vesterb. = Trolldrufva.

$\div$ Hunddill, m., Nerike $=\nabla a ̄ g$. senap.

$\div$ Hundfloka, fo, Norrl. $=$ Nordisk Stormhatt, Aconitum Lycoctonum L.

$\div$ Hundfötter, m. pl. = Musfibla.

$\div$ Hundgrãs, n., Dal. = Qvickrot.

\section{Hundliven = Brunhven.}

Hundlivete, n., Triticum caninum L.

Hundkax, m., eller Hundkäxa, f., Hundloka, f. Dessa namn anrändas utan åtskilnad på arterna af slägtena Chcerophyllum L. och Anthriscus Prns., båda hörande till Umbellaterna, med mycket sammansatta blad och släta frồn utan upphöjda åsar. Lämpligast fördelas de så, att Hundlokan föres till Chørophyllum och Hundkaren eller Hundkäxan till Anthriscus. - I Dalarne är namnet Hundloka tillagdt Björnlokan. $\div$ Hundkummil, m. = Hundkax. Hundlök = Ängslök.

Huudrofra, f., en klängräst tillhörande Gurkräxterna, med stor, tjock: rot, flikiga, sträfra blad och srarta bär: Bryonia alba L. - Hundrofrans rot, som har en rämjelig lukt och skarp smak, kan bli tjock som en mans arm. RETZIUS 1: 132.

Hundtunga, f., öfrersättring af Cynoglossun; växten (C. officinale L.) kallas så för sina mjukludna blad, i motsats till den strüfbladiga Oxtungan (i Dalins ordbok säges origtigt, att Hundtungan är "sträfbladign). Benämnes annars Munkfnat.

\section{Hundriol, se.Viol.}

Hundäxing, m., ett allmänt grässlag med hopgrttrade smáar, rända ât en sida: Dactylis glomerata L. Hundäringen är ett mångårigt, rpperligt fodergräs. - Namnet föres i allmogespråket äfren till Qvickroten.

\section{Hungerkorn, se Brandkorn.}

Huslök, m., benämnes ofta så räl Taklöken som Kärleksörten. -»Denne väst är på torftak den allratjenligaste att qrarhålla mullen, hrarigenom ett tak, som är öfrerruxet med denna ört, kan uthärda hela hundrade åren». Linnés Sk. resa 18.

Hussvamp, m., kallas vanligast Svamp $i$ hus. Se Träfrätare.

Hren, f., egentligen grässlägtet Agrostis L., men i folkspråket tillägges namnet $\mathrm{i}$ allmänhet finare, spensligare gräs med rippa, t. ex. Kruståda, äfren arter af Rör, såsom Piphven. Samtliga arter af Hren äro goda fodergräs, i șnnerhet Brunhvenen (Agrostis canina L.) och Kryphrenen (A. stolonifera L.).

Hrete, n., ett allmänt bekant sädesslag: Triticum I. Deraf finnas talrika förändringar, äfren arter, t. ex. Kubbhvete, Vinterhvete, Vårhvete m. Il.. hrilkas närmare bestämmande tillhör ekonomiska skrifter. Ären Spelten är 
en art Hvete, men högst olämpligt benämner man Majsen Turkiskt Hvete. - nDe så hvete, men tistel skola de uppskiiran. Jerem. 12: 13.

Hvifva (äfven Vifva), f., ett örtslägte med bar stängel och trattlika blommor, typ för Hvifvevästerna : Primula L. - Namnet kommer sannolikt af fornsv. hvif, qvinlig hufvudbonad (hufva). -De mest bekanta arterna äro:

Aurikel-hvifva, se Aurikel.

Gulhvifva (skrifves äfven Gullhvifva), med gula blommor: $P$. veris $\mathrm{L}$.

Majhvifva, med gredelina blommor och på undre sidan hvitmjöliga blad: $P$. farinosa $\mathbf{L}$.

På majfälten blommathritsippan och vifvan.

$\mathrm{Du}$, gullvifva,

Glans må gifva

At den gröna äng. Dens. 1: 132.

Hvifreväxter, Tvåhjertbladsväxter med fem den sambladiga blomkronans flikar motsatta ståndare och enrummigt fröhus med centralt fröfäste : Primulacece Vesr.

$\div$ Hviloreda, f., är sannolikt det rigtiga uttalet af villoreda (se detta namn).

$u \div$ Hrita Dejor, Hvita Pigor m. fl., se Hvitört.

« $\div$ Hvita Dufvor $=$ 'stjernlök.

$\backsim \div$ Hvita Klockor, Medelpad $=$ Linnésört.

$\sim$ Hvit-al, se Arre.

u Hvit-andorn, se Andorn.

Hvitatåfva, se Täfva.

Hvitbeta, se Beta.

Hritbok, se Annibok.

$\div$ Hvitglygg, m., Verml.= Spergel.

Hvitgröe, se Gröe.

$\div$ Hvithufvud = Ängdun.

Hvitklöfver, se Klöfver.

Hvitkål, se Hufvudkål.

Hvitlåcka, se Låck.
Hvitlök, se Lök.

Hvitlöksört, f, en ört af Kålväxternas afdelning, med hjertlika blad, hvita blommor och stark lukt af hvitlök: Alliaria officinalis Axbnz.

† Hvitmeja, f., i norra Skåne, enligt Linné = Hvitsippa.

Hritmossa, f., ett slägte bland Mossorna, hvilket i stora massor uppfyller alla skogskärr: Sphagnum L. Kallas äfven Rödmossa.

Hvitmåra, se Måra.

Hvitpeppar, se Peppar.

Hvitpil jésil.

Hritpoppel = Silfverpoppel:

+Hvitrik, m., en af Liljeblad bildad benämning efter det Latinska $A n$ thericum. Det är väl icke möjligt att ana hvad ett sådant namn skall betyda.

Hvitrot, f., Smål.= Qvickrot.

Hvitsenap, se Senap.

Hvitsippa, se Sippa.

Hvitväpling $=$ Hvitklöfver.

† Hvitört, Hvita Dejor, Hvita Pigor, Hvitkullor, Hvit-tuppor, Hritateja m. fl. Alla dessa namn tilläggas Kamillblomster, Åker- och Surkullor samt Baldersbrå på olika orter, äfvensom på samma ort, utan att vara bestämda.

Hyacint, m., en från Orienten införd Liljeväxt, som odlas: Hyacinthus orientalis $\mathrm{L}$. Denne är icke de gamles Hyacinthus. - I घh re tider fördes till Hyacinterna äfven slägtet Muscari, som derföre kallades Drufhyacint, Perlhyacint. Se Drufhyacint och Perldrufva.

Du hyacint, som ej din like

I färg, i glans, i täckhet har

Bland all din slägt i Floras rike!

Festligt hyacinten ler

H. C. NORDENFLYCHT 243 .

I blia kropors drägt. STAGXELIUS 2:165.

Hyll, m., är det namn, som i vårt liksom i öfriga Germaniska språk till- 
kommer slägtet Sambucus L. En buske deraf (S. nigra L.) kallas nu vanligen Fläder; men benämningen $H y l l$ bibehålles för slägtets andra, med örtstam försedda art (S. Ebulus L.), hvilken kallas Sommarhyll. Jfr Ättiksbär.

+ Hylslaf, hos Liljeblad namn på slägtet Sphcerophoron PErs. Utgår alldeles. Jfr Kraslaf.

Hylsväxter, T'våhjertbladsväxter med fem ståndare på den sambladiga kronan och med tvenne enskaliga, långs efter uppspringande fröhylsor: Asclepiadece $\mathrm{R}$. Br.

Hålkblomstrige, se Blomhålksväxter.

+ Hållbär, ett alldeles obestämdt namn, som tillägges vilda, icke ätliga bär, i Småland Besksötans, i Roslagen dem på Paris quadrifolia L., o. s. v. Trollbär, Ormbär, Villbär kunna anses som synonymer.

Hållsknoppar, m. pl. = Knylbräcka. "Saxifraga granulata kallades Hållsknoppar, rötterna torkades, pulveriserades och intogos af bönderna i pleurisien. Linnés Öl. resa 61 .

Hållsrot, f. 1) Örtslägtet Aristolochia L., tvåhjertbladsväxt med egen-

^ domligt bildade, strutlika blommor och vidt krypande rötter, hvarigenom den inhemska ( $A$. Clematitis L.) blir ett besvärligt ogräs. - 2) I Halland namn på Alant.

+ Hålrot, se Hålört.

† Hålsgräs, hos Linné=Halsgräs.

+ Hålört, f., Corydalis cava (L.). Se Nunneört. Namnet förekommer hos äldre författare, men är nu obrukligt.

Hårdved, m. Detta namn tillkommer rättast buskväxten Rödá Kornellen, men kan ej antagas som slägtnamn för Kornell, emedan den andra inhemska arten af detta slägte är en ört (se Hönsbär). I folkspråket föres namnet kanske oftast till Try. Jfr Linnés Sk. resa 265.
Hårkullor, f. pl., Öland = stor Knoppört: Centaurea Scabiosa L.

Hårlaf, se Laf.

Håruacker, m. pl., Öland = Visil.

Håruate, m., en med Nate närbeslägtad växt, med hårlika blad och skaftade frukter: Ruppia L. Alla arter af Hårnate växa $i$ hafvet.

Hårserf, m., lik den näst föregående, men har han- och honblommor skilda och blott en ståndare: Zannichellia $\mathrm{L}$. Hårserfven är en liten, i vatten nedsänkt växt:

Hårtandsmossa, Hårtofs, i Dalins ordbok efter Liljeblad upptagna namn, förtjena icke ens omnämnas.

Hårväxter, m. pl., Vesterg. = Hästfibla.

† Hårört, f., hos Liljeblad olämpligt namn på Hornserf.

Hägg, f., ett med Körs närbeslägtadt Stenfruktträd, med vackra hvita blomklasar och små svarta bär: Cerasus Padus Deo. Häggens bär hafva en mycket sammandragande smak.

Häggen, som i skogen

Var först med blommor klädd och sist med frukter mogen. OXENSTJERNA 2: 152 .

Hällebråken, $\mathrm{n}_{\text {, , en liten finluden }}$ Bräkenväxt, växande $\mathrm{i}$ bergspringor: Woodsia ilvensis $\mathrm{R}$. Br.

Hälleknopp, m. (Hällegräs obrukligt) = Hvit-fetknopp. Ehuru blott ett provinsnamn (i Småland, Dalsland), torde detta synonym böra upptagas.

Hängeräxter (Amentacece I.o) äro träd eller buskar med blommorna i hängen, t. ex. Ask, Björk, Ek, Hassel, Vide.

† Hära, f., Dalarne = stagg.

Hässlebrodd, m., ett välluktande gräs med yfvig vippa och enblommiga småax: Milium effusum L.

Håsslekål, m., en art af slägtet Blåklocka (Hässleklocka), som är en 
af de förnämsta inhemska värter att använda till grönkål.

\section{$\div$ Haistblad $=$ Hästhofsört.}

Håstböna, se Böna.

Hästfibla, f., en i Göta rike allmän Blomhålksväxt, liknande Fiblorna, men har pipiga diskblommor: Arnica $\mathbf{L}$. Benämningen brukas i Småland och flerstïdes. Hästblomster (Dalsland), Horsafibla (Småland, äfven Skåne, se Linnés Sk. resa 359) äro variationer af namnet.

$\div$ Hästgröning, m., Jemtland $=$ Skogsfräken.

Hästhofsört, f., en gulblommig Blomhålksräxt, som tidigast om vâren blommar på enkel, fjällig stängel före bladens utsliende: Tussilago Farfa$r a \mathrm{~L}$.

Hästkastanie, m., ett resligt, lummigt träd med sjufingrade blad och stora blomruskor, sju ståndare: $\lambda E s c u$ lus Hippocastanum $\mathrm{L}$. Hästkastanierna äro införda från Högasien och nu hos oss allmänt planterade.

Der högstammig och stolt kastanien paras med lindar.

\section{Hästljung, se Ljung.} DAHLGREN 1: 141.

\section{Hästmynta, se Mynta.}

$\div$ Hästskoblad, n., af Wahlenberg tillagdt Nympharacece såsom slägtnamn.

$\div$ Häistsvans, m. (äfven Hästrumpa), ett $i$ formelt hänseende obrukbart namn, och i hög grad förvillande, såsom tillagdt de mest olikartade växter. I skriftspråket tillägges det vanligen Hippuris L., hvaraf det är ,en öfversättning, men i- folkspråket Fräken eller Equisetum L., hvilket senare ord har samma betydelse, äfvensom flere andra växter, t. ex. Kropp.

\section{Haistsyra, se Syra.}

$\div$ Hättebär, n., Vesterg. = Backsmultron.

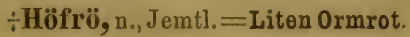

Hökblomster, n。, rättare Hökfibla, f., ett artrikt slïgte, tillhörande Fibleväxterna, med oregrelbundet öfrer hvarandra liggande hallkfjäll och i spetsen tvärt afhuggna frukter med fruktfjun: Hieracium $\mathbf{L}$.

$\div$ Hömjölke, m., Dalarne= Kropp.

Hönsarv, m., örtslägtet Cerastium L., tillhörande Narfväxterna, utmärkt af hornlika, i spetsen tiotandade fröhus. Kallas i Småland Hönstarmar, och märkvärdigtvis finnes detta namn (Hühnerdarm) anfördt redan i abbedissan Hildegards Physica (före år 1180).

Hönsbane, m., en Skånsk (Dansk och Engelsk) benämning på Bolmörten. Orätt uppgifves Hönsabale i Linnés Sk. resa, s. 115.

Hönsbet, f., Hönsgräs, n., örtslägtet Sagina L., tillhörande Narfväxterna, hvars samtliga arter äro mycket små, skilda från Spergel genom saknaden af stipler. Namnet förekommer redan hos Franckenius.

Hönsbår, äfven Hönson, n., en art af slägtet Kornell, med små svartpurpurfärgade blommor inom ett fyrbladigt hvitt svepe: Cornus suecica L. Hönsbären äro orrens läckerhet; deraf namnet.

Amm. Dalin bildar vanligen till hvarje bärnamn ett särskildt namn på plantan, men till Hönson särdeles olyckligt Hönsbärsbuske, ehuru. växten har örtstam.

Hönshirs, se Hirs.

† Hönsruta, f., enligt Dalins ordbok Veronica triphyllos $\mathrm{L}$., är ett både opassande och i folkspraket okïndt namn pâ en sällsynt och mycket liten växt.

† Hönstarmar, m. pl., se Hönsarv.

Hör, m., inhemska namnet på Lin, allmänt brukligt bland allmogen i Göta rike.

Hörkäring, f., Vesterg. = Lindodra.

$\div$ Hörsilke, n。 = Linsnarrefva. 
Höskallra, f., örtslägtet Rhinanthus L., tillhörande Skeplingsväxterna, med platta, kretsrunda frukter (deraf Penninggräs) och vid mognaden skallrande frön (deraf äfven skallergräs). R. Crista galli $\mathbf{L}$.

Höst-adonis, se Adonis.
Höstfibla, f., örtslägtet Leontoclon L., tillhörande Fibleväxterna, med bladlös stängel och skaftadt fruktfjun. $L$. autumnalis och hispidus $\mathrm{L}$.

Höstklocka, f. = Klock-stålört. + Höter eller (Gotl.) Hauter, m. pl. $($ ?) = Knapptång.

\section{I.}

+ Iber, f., ett af Liljeblad bildadt namn på örtslägtet lberis L. bland Krasseväxterna; den art, till hvilken namnet af honom hänfördes (I. nudicaulis L.) tillhör dock numera icke detta slägte, hvaraf ingen art är inhemsk, men väl några odlas som prydnadsväxter. Dessa, likasom andra utländska odlade växter, behålla bäst sina Latinska namn ostympade.

+ Ibisrot, f., ett alldeles okändt namn på Althéroten.

Id, Idgran, f. (jfr. Isl. $i ð j a-g r c e n n$, ständigt grön), ett ständigt grönskande barṛträd, hvars småkottar öfvergå till mjuka bär: Taxus baccata $\mathrm{L}$. Idgranens trä är ségt och'lemnar det vackraste slöjdvirke. Bären äro giftiga.

Itureern af iden bereder sin båge. ADLERBETH 85.

Ideträn af kölden och nordan förnöjas. Dens. 75.

Igelknopp, m., ett slägte bland $\checkmark$ Etthjertbladsväxterna, med stora jemnbreda blad och till ett rundt, stickande hufvud förenade frukter: sparganium L. Se Träggan och Flotagräs.

Iglegräs, n., Vesterg. = Narthecium ossifragum, enligt Linné. Om $\checkmark$ denna växt gâr den sagan, att efter dess förtärande benen brista hos boskapen. Hvilken växt.dermed menas, är ovisst. Se Ilagräs.
+ Iguatii-böna, f., frukten af $I g$ natia amara $\mathrm{I}_{\text {. }}$ Kan svårligen anses tillhöra Svenska språket.

Igrön, se Ivgrön.

Ikorr*, se Ekorr-

r

+Iktebiix (af ikt, gikt), n. = Trolldrufva.

Iktegräs, n. (Giktört) = Gul Ängsruta, men i Dalsland är namnet tillagdt Ältgräset.

Ilagräs, n., en kärrväxt, som enligt Småländska allmogens tro förorsakar små milare” (maskar) i lefvern eller i hjernan hos farr; men ingen vet, hvilken växt dermed egentligen menas. Är nog samma namn som Iglegräs.

+ Ilek, f., ett olyckligen bildadt namn af Ilex; denna växt är ingen Ek, utan en vida skild buske = Krist-torn. Se Jernek.

\section{Illermjölke, se Imjölke.}

+ Illnaträd = Elnaträd.

+ Ilrot, f. = Qvickrot.

Imjölke (Nerike), Illermjölke (Hels.), m. = Kropp. Dessa namn, jemte Almocke, Aldermjölk, Ållonmärke, äro troligen olika uttal, med flere medelformer, af samma stamord. Jfr Mjölke. 
+ Indalsris, n., Liljeblad = Klådris.

Indigo, m., ett blått färgämne, som erhålles af flera arter utaf slägtet Indigofera L., tillhörande Ärtväxterna.

Ingefära, f., en mycket hettande krydda, som fås af roten till Zingiber officinale Rosc., tillhörande Kryddliljornas familj (Scitaminece 1.). - Finsk Ingefära kallas den skarpa, hettande roten af en Svensk Umbellat: Peucedanum palustre MoExon (Mossrot). Dansk Ingefära, se Munkmössa.

Insektpulver, $n$., frön af en med Krageblomman närbeslägtad ört: $P y$ rethrum roseum Bies.

+ Ipecacuanha, f., ett mycket verksamt kräkmedel, som erhålles af flere Sydamerikanska växter, såsom Cephaëlis Ipecacuanha Ricr., Jonidium

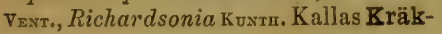
rot.

Islandslaf, se Laf.
Isop, m., en i södra Europa inhemsk, i Sverige odlad kryddväxt af Sugeväxternas familj: Hyssopus officinalis. L. Har brukats till heliga förrättningar. - Skära mig med isop, att jag må ren varda. Psalm. 51: 9.

Stänkte signadt vatten ur

Isopsqvast på nybyggd mur.

TEGNER $1: 225$.

Anm. Den isop, som nämnes 1 Konungaboken 4: 33 , måste vara felaktig öfversättning och en helt annan vïxt, troligen Mossa eller Laf.

Isört, f., ett synnerligast på Cap ytterst artrikt örtslägte, med köttiga, saftfulla blad och sköna, mångbladiga blommor: Mesembryanthemum L. Arterna förekomma hos oss endast i orangerier; men den art, som gifvit anledning till namnet, växer i Medelhafstrakten och är betäckt med vårtor, hvilka se ut som islika kristaller: $M$. crystallinum $\mathrm{L}$.

Ivgrön, Igrön (Franckenius), f. $=$ Sinngrön.

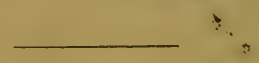

J.

† Jakaranda, f., ett hårdt Brasilianskt trä, som erhålles af flera arter utaf slägtet Jacaranda Juss. (förr Bignonia $\mathrm{L}$.). Användes till finare snickeriarbeten.

+ Jalappa, f., ett bekant laxermedel, som făs af roten till Ipomoea Purga HATNE.

$\checkmark$ † Jalbär, $n_{\text {. }}$ Hels. $=$ Hjortron.

u

† Jamaika-peppar $=$ Kryddpeppar.

Jams, vanligen Yams, m., namn

$\checkmark$ på rötterna af några med Liljorna beslägtade växter från Söderhafvets öar (Dioscorea alata och sativa $\mathrm{L} . \mathrm{m}$. fl.), hvilka rötter $i$ de varma länderna odlas som näringsmedel.
†Jansmesseblomster, $n$., Retzius $=$ Ängsnäfva. Jfy Midsommarsblomster.

Jasmin, m., ett artrikt slägte i södra Europa och Orienten, af hvilket en ". art, den Välluktande Jasminen (Jasminum odoratissimum l.), hos oss i synnerhet odlas. Ma ej förvexlas med Schersmin.

Jemna, f., en art af Lummerslägtet, med platta grenar och vidvurna blad af tvà slag: Lycopodium complanatum L. Jemna är mycket anyänd till gul färg.

Jernek, f., en i södra Europa växande art af Ekslägtet: Quercus llex L. 
Jag förmodar, att denna afses med den af Dalin upptagna Ilek, som i alla fall är ett ohjelpligt namn.

Jernrot, f., benämning på växter med mycket hårda och sega rötter, såsom Stora Knoppörten, 0xtungörten (båda uppgifna från Gotland) m. fl. Jfr Rast.

Jernört, f., de mångåriga arterna af slägtet Knoppört, i synnerhet $C e n-$ taurea Jacea I. För denna är namnet Jernört så allmänt kändt, att det borde i riksspråket antagas som slägtnamn. Dock kallas i Skåne äfven Pedicularis L. för Jernört. Se Linnés Sk. resa 277.

Blå Jernört = Vägvårda. Jfr Linnés Sk. resa 400 .

I skriftspråket och i våra ordböcker hänföres namnet Jernört till Verbena L. Men för denna är benämningen föga lämplig, och jag skulle förkasta den, om den icke vore nära enhälligt antagen. - Ännu orimligare föres namnet i Dalarne till Capsella L. ; men här, som i flera andra fall, förmodar jag ett misstag af upptecknaren.

\section{$\backsim$ Jettebröd, se Jettelaf. \\ $\sim$ Jettegröe = Kasevia. \\ $\sim$ Jettelaf, se Laf. \\ $\checkmark$ Jetteticka, se Ticka. \\ + Jogere, m., Dalsland = Kråk- vicka.}

+Johannésblomster, n., Gotland $=$ Letkullor. Namnet föres äfven till Johannesknopp.

Johannesbröd, $n_{\text {:, }}$ ett $\mathrm{i}$ medicin användt växtämne, som erhålles af mergen i ärtbaljorna på Ceratonia Siliqua L., en i Medelhafsländerna växande buske med parbladigt sammansatta, ständigt grönskande blad och små, klasvis sittande blommor.

\section{Johannesknopp, Johannesört,} numera det allmännast brukliga namnet på slägtet Hypericum L., med fem-

Fries, Svenska växtnamnen. bladig, gul blomkrona och talrika, i fem knippen sammanväxta standare. Af dess arter äro två allmännare kända:

Fyrkantig Johannesknopp, med fyrkantig stjelk : $H$. quadrangulum $\mathrm{L}$.

Äkta Johannesknopp, med tvåeggad stjelk: H. perforatum L.

$\div$ Johanneslök, m. = Chalottenlök. - Namnet utgår, såsom alldeles onödigt.

+ Johannesnycklar, Gotland $=$ Nyckelblomster.

Johannesört, se Johannesknopp.

Jolster, f., ett öfver hela landet värande träd eller buske af Pilslägtet, med glänśande löf och vårtlika knoppar på bladskaften: Salix pentandra L. Namnet vexlar i uttal inom hvarje landskap : Halster, Hilster, Hjelster, Ilster (Isl. ilstri, neutr.), Jolster, Juster 0 . s. v. Alla dessa former förekomma, enligt Walpers, äfven i Tyskan.

Jonqvill, f., en art af Narciss, med flerblommig stängel och hvita blommor: Narcissus Jonquilla L.

Jonqvillen lyfts på smala stjelkars rot.

Jord-artskock, se Artskock.

Jordbär (äfven Jolebär), n., det allmänt brukliga namnet på Fragaria vesca L. i Göta rike, liksom i Danskan (i Tyskan Erdbeere); deń i Svea rike mest förekommande benämningen Smultron är i skriftspråket antagen.

Jordgalla, f., föres af våra äldre botanister (Franckenius, Tillandz, Bromelius) till Äng-stålörten, men af Liljeblad (och efter honom i Dalins ordbok) till den utländska Gratiola offciralis $\mathrm{L}$.

+ Jordgaltar, m. pl.= Brudbröd. Se Linnés Sk. resa 240, 270.

Jordgubbar, m. pl., se Smultron. Jordhumle, m., ett mångtydigt namn, som rätteligen tillkommer Humlesugan, så väl för hennes egenskaper, 
hvilka närma sig Humlens, som enligt våra äldste botaniske författare. Men i folkspråket föres det till Brunörten (Dalsland), Röllikan (Dalarne), Gullklöfvern (Småland) och Johannesknoppen (Skåne, enligt Linnés Sk. resa 319 ).

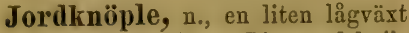
ört, hvars frukt liknar Lin, med hvilket slägte den af Linné förenades: $R a^{-}$ diola millegrana Ss.

Jordkrona, f. Af Linneas talrika namn i folkspråket är detta det enda som kunde förtjena upptagas i riksspråket; hennes systematiska namn blefve då Linnés Jordkrona.

Jordkrypa, f., Vesterg., ett passande namn på Äkta Ärenpris.

† Jordlefver (hvit, röd o. s. v.) $=$ Klöfversiägtet. Namnet uppgifves från Vestergötland; möjligen rigtigare Jordrefvor.

Jordlunga; f., ett slägte bland Lefvermossorna, med mycket breda blad och skaftade, sköldlika, i kanten stråliga frukter: Marchantia $\mathrm{L}$.

† Jordmandel, m., en i södra Europa odlad art af slägtet Cyperus L., med atliga rotknölar: C. esculentus $\mathrm{L}$. Emedan den hvarken odlas hos oss eller kommer hit som handelsartikel, tvekar jag, om namnet bör upptagas.

† Jordmossa (Phascum L.) utgår alldeles.

† Jordnafle, m., benämnes enligt Wảhlenberg slägtet Chrysosplenium L. Namnet är obrukligt och tillkommer, enligt äldre författare, mera lämpligt Hydrocotyle L., men lämpligast, om man vill gifva Svenska namn at utländska växter, slägtet Umbilicus DEo.

Jordnöt, f., en art af slägtet Kummil, med knöliga, ätliga rötter: Carum Bulbocastanum Koor. (I Dalins ordbok förvexlas detta namn med Jordmandel.)
Jordpäron $=$ Potates.

Jordrefva, f.; en ört af Sugeväxternas familj, med refviga, krypande stjelkar, njurlika blad och små blåa blommor: Glechoma hederacea L. Jordrefvan användes till bröst-the.

Jordrök (äfven Åkerrök),m., örtslägtet Fumaria L., tillhörande Kronsporreväxterna, med mångdelade blad, axlik blomklase, små enfröiga frukter. Namnet, bildadt efter Latinet, är allmänt antaget i skriftspråket, men tillhör ej folkspråket. Inhemska benämnịngar äro Gallgräs, Ảkersilke.

Jordstjerna, f., ett utmärkt slägte bland Röksvamparne, hvars yttre hylle uppspringer i stjernlikt utbredda flikar: Geaster Mron.

Jordstråla, f., ett slägte bland Lefvermossorna; med strål-likt utbredda bladflikar: Riccia $\mathrm{L}$.

Jordsvamp, m. Så kallas svampar som växa på bara jorden, i motsats till Trädsvampar, Bladsvampar. De som vära under jorden benämnas Underjordsvampar. Att särskildt föra namnet Jordsvamp till Tuber Mron. är så mycket mera olämpligt som denna eger ett allmänt kändt namn: Tryffel.

Jordtistel, se Tistel.

Jordvide, se Vide.

Jordäpple, n. 1) En afdelning af Buksvamparne, lik Röksvampar, men den inre massan upplöses icke till ett fint pulver: Hymenogastres $\mathrm{V}_{x x т}$. 2) I Småland benämning på Jord-artskock, i Vermland på Potates.

†Judasöroll, n. pl., benämndes fordom på apoteken en geléartad svamp: Hirnenla Auricula Judae Benk. Växer på Hyll i mellersta och södra Europa, men är ej funnen i Sverige, ehuru upptagen i Linnés Fl. Svec. (Tremella Auricula $\mathrm{L}$. .) $^{2}$ 
Judekirs, m., frukten af Physalis Alkekengi L. Denna tillhör Bolmväxterna, mien frukterna äro ätliga.

† Juglon, n., Roslagen = Nypon.

+ Jungermansmossa (Liljeblad) utgår alldeles.

Jungfru ingår $i$ en stor mängd växtnamn, af hvilka de flesta afse Jungfru Maria, ehuru ordet Jungfru stundom vid uttalet bortfaller. Ibland utelemnas Marice, och endast Jungfr $u$ begagnas. Jag har ansett lämpligast att här i en följd sammanföra alla dessa namn och derefter uppgifva dem, i hvilka Jungfru ej kan med säkerhet hänföras till Jungfru Maria. Den stundom brukliga benämningen Vår fru afser Jungfru Maria.

Jungfru Mariæ barnmössa (Vesterbotten), ett utmärkt vackert Mossslägte, med ett uppblåst bihang under frökapseln: Splachnum luteum och $r u-$ brum $\mathrm{L}$.

J.M:blomma, Gotl.= Majhvifva.

J.M. brudgran, Vesterb. = Brudsporre.

J. M. bröst, Österg. = Fläckigt Nyckelblomster.

J. M. bär, äfven Mariæ bär =1) Vestmanl. Stenhallon; 2) Helsingl. Vikon.

J. M. förkläde, Smål, = Fläckigt Nyckelblomster.

J. M. gräs, Wahlenberg = Myskegräs.

J. M. hampa, hör, lin, tonad, Smål. m. fl, st. = Jungfrulin.

J. M. hand, allmänt = Fläckigt Nyckelblomster.

J. M. hjerta, Dalsl.= Hvit Visil.

J. M. kam = Alchemilla Aphanes, se Jungfrukam.
J. M. kåpa, Medelpad m. fl. st. = Daggskål.

J. M. nyckelband, Bohuslän = 0xtungört.

J. M. nycklar, Vesterg. = Gulhvifva.

J. M. ris, Verml, = Gullris.

J. M. rock, Dalsland = Fläckigt Nyckelblomster. hår.

J. M. sileshår, allmänt = Siles-

J. M. $\mathbf{s k 0}=$ Guckusko. $($ Calceolus Marice.)

J. M. sänghalm, allmänt $=$ Gul måra. - I Elfdalen (Dalarne), enligt uppgift $=$ Sileshår, men troligen ett misstag.

J. M. särk, Gotl. = ̊̊kervinda.

J. M. tistel = sempertin.

J. M. tå̀rar = sileshår.

J. Y. ögon = 0̈gonblomma.

Jungfrukam, m. 1) = Nålkörfvel. Namnet är en öfversättning af Lat. Pecten Veneris och afser ej Jungfru Maria. 2) En art af slägtet Daggskål: Alchemilla Aphanes LEERs.

Jungfrulin, n., örtslägtet Polygala L., hvars blad likna.. Linets, men blommorna närma sig Ärtväxternas. Jungfrulinets blommor skifta i hvitt, blått, fiolett och rödt.

Jungfrun i det gröna kan lämpligare kallas Jungfrukorg: Nigella damascena $\mathrm{L}$.

$\div$ Jungfruris, n., Verml. = Gullris. Se Jungfru Mariæ ris.

$\div$ Jungfrutvål, $m_{.}=$Brännande Pilört.

Jungfruögon, n. pl., se Theärenpris. 


\section{$\mathrm{K}$.} dun.

Kabbar, m. pl, Nerike = Kafvel-

Kabbelök, Kabbelek, m., Kalfleka, f., en på kärrängar allmän ört, blommande tidigt om våren med gullgula blommor: Caltha palustris $\mathrm{L}$.

Anm. Det i Småland förekommande uttalet Krabbelök synes vara namnets ursprungliga form. I Halland föres örten till slägtet Låck, Låcka (derstädes uttaladt Laga), d. v. s. Sippa. I Dalarne, hvarifrån man har så många vexlande namn och stridiga uppgifter, benämnes den Necktuppor, Pasktuppor m. fil.

+ Kabelrotting, m., en för sin utomordentliga höjd utmärkt art af Rottingslägtet, i Ostindien: Calamus Rudentum Lour.

Kaffetråd, m., ett ständigt grönskande mindre träd i Abyssinien, derifrån infördt till Arabien och nu allmänt odladt i de varma klimaten: Coffea arabica $\mathrm{L}$.

Kafferkorn, $n$, se Durrha.

Kaffevicka, f., benämning på ärtväxter från södra Europa, odlade som kaffe-surrogat, t. ex. frön af Astragalus baticus $\mathrm{L}$. och en art Lupin.

† Kaffskägg, n., enligt Linné en Småländsk benämning på stagg. Jag har dock hört endast namnet Kalfskägg.

Kaflegräs, n., grässlägtet Alopecurus L., med axlikt sammandragen vippa. I sammansättningar bortfaller ordet gräs.

Kärrkafle, m., med knäböjdt, nedliggande strå: : A. geniculatus $\mathrm{L}$.

Ängkafle, med högt, rakt strå: $A$. pratensis $\mathrm{L}$. Ypperlig foderväxt.

Kafveldun, n., högväxta, till Halfgräsen sig nürmande vattenväxter, med stora blad, blommor i tvenne kolfvar, den öfre med hanblommor, den nedre med honblommor och rikligt fröfjun:

Typha L. Man har deraf en bredbladig och en smalbladig art.

Kafvelhirs, se Hirs.

Kakao, m., bönorna af Kakaoträ$\operatorname{det}$ (Theobroma Cacao L.) från Mexico. Användas till choklad, kakaosmör m.m.

Kalatänder (d. v. s. gubbtänder), Smål. = Flugsporreblomma.

Kalebass, m., en Amerikansk art af slägtet Pumpa, hvilken urhålkad begagnas till flaskor: Cucurbita Lagenaria $\mathrm{L}$.

+ Kalebassträd, en nästan okänd benämning på ett kolossalt Afrikanskt träd, som bäst bibehåller sitt vetenskapliga namn Adansonia digitata $\mathbf{L}$. eller ock infödingarnes Baobab. Se Apebrödsträd.

+ Kalfbär, Österbotten = Måbär.

+ Kalfhjortron, Upland = Blåhallon.

Kalfhufvud, $\mathrm{n} .=$ Skalleblomma. Kalfleka, se Kabbelök.

Kalfnos, f., Skåne = skalle- $\nu$ blomma.

+ Kalfrefvor, f. pl. = Matt- och Reflummer.

† Kalfrumpa, f., Upland, odugligt namn på Kropp.

Kalklaf, se Laf.

Kalkonsnabel, m., se Amarant.

Kallgräs, ett mycket allmänt namn, men tillagdt fyra olika växter af slägtena Pedicularis I.., Comarum L., Spircen L. och Scheuchzeria í., dock lämpligast bibehållet för den sistnämada, en i kärr växande ört af Svaltingsfamiljen, med trinda blad och treknöliga frukter: S. palustris L. Jfr Frier.

Kalmus, m., en svärdlik vattenväxt med blomkolf på sidan af den bladlika stjelken: Acorus Calamus 1. 
Den underjordiska stammen af Kalmus (i vårdslöst uttal Kalmarerot) är mycket aromatisk, hettande, använd i medicin.

Kambräken, n., ett slägte bland Bräkenväxterna, hvars fruktbärande blad äro inskurna i smala, kamlika flikar: Blechnum boreale sw. (Det i Dalins ordbok upptagna Kamblad hör hit, men bör utgå, såsom obestämdt.)

+ Kamelblom, Wahlenberg $=$ Blomvass. Obrukligt namn.

Kamfert, m., en fast, eterisk olja, som erhalles af ett träd tillhörande Lagerfamiljen: Camphora officinarum NEEs.

† Kamgräs, obestämdt namn på Kamäxing och Tofsäxing, som bör alldeles utgå.

Kamillblomster, n., Kamillblomma, f., en allmänt antagen, efter Lat. Chamomilla bildad benämning på Matricaria Chamomilla L. (Men den äkta, Romerska Kamomillen, Anthemis nobilis $\mathrm{L} .$, är en helt annan växt, som i "Svensk Botanik" alldeles origtigt förenas med den här ifrågavarande.) Namnet har i allmogespråket blifvit mycket förvridet, såsom Kalablomster, Kommenteblomster o. s. v.

Kammar, m. pl,, rättare Kamnäfva, ett från Näfva nyligen skildt slägte, med mycket findelade blad: $E$ rodium cicutarium Herit.

Kampegräs (egentligen Kämpegräs), n., lätt urskildt genom sin axlika blomning och sina gaffellikt uddiga småax: Phleum L. - Om namnets anledning se Bot. utfl. 3:234. - Ordet gräs bortfaller i sammansättningar.

Flenkampe, m., en mindre art, växande på torra backar: $P$. phalaroides Kors.

Ängskampe, ett af de allmännast odlade fodergräs, ofta under det främmande namnet Timotej: P. pratense $\mathrm{I}$.
Kampeschtråd, ett Brasilianskt trädslag, hvars ved lemnar blå bresilja. Se Bresilja.

+ Kamtåtel, m. Detta endast i systematiskt intresse bildade namn utgår alldeles, emedan Koeleria Prrs. (se Tofsäxing) icke kan förenas medTåtelslägtet.

Kamäxing, m., ett utmärkt gräs, lätt skildt genom sina kamlika skärmar under småaxen: Cynosurus cristatus L.

Kanadabalsam, m., hartset . af Kanadagranen (Pinus canadensis L.), ett Nordamerikanskt barrträd.

Kanariegräs, n., ett odladt grässlag från Kanarie-öarna, hvars frön lemna bästa föda àt kanarie- och andra sångfoglar: Phalaris canariensis $\mathrm{L}$.

Kanel, m., den aromatiska barken af Kanelträdet, från Ostindien: Cinnamomum ceylanicum NeEs.

Kanelros, se Törnros.

Kantarell, m., /en ätlig och välsmakande, gullgul svamp: Cantharellus cibarius. Fr. "Chantarellen, en svamp som ätes, ... var dermed skild ifrån alla af sin slägt, att dess lameller (skifvor) grenade sign. Linnés Vestg, resa 215. Ordet är Arabiskt: kantar, som betyder svamp i allmänhet.

† Kantklocka, f., en sällan bruklig benämning på Nässleklockan.

+ Kantknopp = Kantfetknopp: Sedum sexangulare $\mathrm{L}$.

† Kantärt, f., en förändring af Allmänna Ärten, med något kantiga frön. Tillhör : trädgårdsspråket.

Kapris, m., blomknopparne på den i södra Europa växande Kaprisbusken: Capparis spinosa $\mathbf{L}$.

† Karbas, m., ett obestämdt och obrukbart namn, af Wahlenberg fördt till Rockentraf, af Retzius till Stinkstallörten, vanligast till unga Björkar.

Karborre, rättare Kardborre, m., ett allmänt bekant örtslägte, till- 
hörande Tistelväxterua (Lappa Touns.), hvars hålkfjäll sluta $i$ en hake, med hvilken de hänga fast vid kläderua.

Kardemumma, f., frön af itskilliga kryddväxter från Ostindien, företrädesvis arter af slägtena Amomum L. och Cardamomum SalrsB.

Kardtistel, m., ett örtslägte tillhörande Väddväxterna, med taggiga stjelkar och hålkfjäll : Dipsacus ı. Kallas äfven Kardskära.

Fabriks-kardtisteln, D. fullonum L., med i spetsen haklikt böjda hålkfjäll, odlas för ullberedning i fabriker.

$\div$ Karlintistel, m., af Carlina $\mathrm{L}$. $=$ Stjerntistel. Namnet, alldeles onödigt, är inkommet från Tyskan, hvari det tillägges en hos oss ej växande art.

Karsöta, Karört, rigtigast Kas: söta, f.. ett i Upland och Österg. ranligt namn på Mjödörten.

Karv, Karve, m., det äldsta inhemska, ännu i Norrland, Norge m. fl. st. brukligaste namnet på Kummil: Carum Carvi L.

Kase, m. 1). Ett gammalt, nu nästan förloradt namn på Vass, men qrarlefrande i Kers och här nedan anförda sammansättningar. - Vid Persnäs pü Oland "letades (firgades) ullet med Kasa eller veppan af rör (vass)». Linnés Öl. resa.115. - 2) Grässlägtet Fluminia Fr., hvilket till utseende och värtsätt liknar Vass, men har mångblommiga småax med treuddiga agnskal: $F$. arundinaceu $\mathrm{F}_{\mathrm{F}}$.

\section{Kasedun, n. = Kafveldan.}

Kasevia, Kasevija, f., ett af våra största gräs, mycket likt Kase, men foderskalen äro kortare än småaxen: Glyceria aquatica $\mathrm{W}_{\triangle \mathrm{ALB}}$.

Kasia, f., ett träd af Lagerfamiljen, bekant för sin vällukt; kallas oftast Kasielager: Persea Cassia Spr.

Kasias blomma och fler ljuf vällukt spridande örter. ADLERBETH 15.
Kassiaträd, n., ett trädslägte i Egypten och Ostindien, tillhörande Ärträxterua, hvaraf tlera arter äro utmärkta för sina laxerande egenskaper: Cassia ᄂ. Se Sennetsblad.

Kassöta, se Karsöta.

Kastanie, m., frukten af det i södra Europa och Orienten värande Äkta Kastanieträdet (skildt från Hästkastanien), närmast, förvandt med Bok: Castanea vesca $\mathrm{G}$ жRTN.

Kastanjernas träd af bördighet yfvas;

Marken i kronornas skygd är höljd af ymniga frukter. ADLERBETH 36 .

Kastlöser, f. pl., efter socknen Kastlösa på Öland $=$ Vår-adonis.

$\div$ Kattballar, m. pl.= Fårkum. mer.

Kattfotsört, f., ett allmänt bekant örtslägte, tillhörande Boväxterna, utan strålblommor: Antennaria Grerrs. Den allmännaste arten är $A$. dioica Gerrs: - I talspråket säges vanligen kattfot, kattfötter.

Kattklor, fo pl., en i Bohuslän, Vermland och flerstädes bruklig benämning på Gigelsärt, men obrukbar som växtnamn: Genom förvexling har benämningen blifrit öfrerförd äfven till Anthyllis L., som dock allmänneligen och af alla bättre botaniske författare kallas Räfklor.

Kattleka, Kattlusta, f., Wahlenberg = Kattmynta.

Kattmynta, f., örtslägtet Nepeta L., tillhörande Sugeväxterna; närförrandt med Mynta, men kronan läppformig och ståndarne närmade till hvarandra. N. Cataria L. Har behaglig lukt, som sökes af katter.

Kattosträxter skiljas från öfriga genom 'stindarsträngarnes sammanväxning till en pelare: Malvacece Juss. Typen för familjen är slägtet

Kattost, m. (Malva 1.), hvars yttre blomfoder är trebladigt. Namnet är 
mycket gammalt och förekommer redan hos medeltidsförfattare.

\section{Allmän Kattost (M. vulgaris $\mathrm{Fr}_{\mathrm{r}}$ ) och}

Liten Kattost (M. borealis W $\mathrm{WLLSO}_{\text {. }}$ ) hafra nedliggande stjelkar, blommorna i krans i bladvecken; den förres kronblad äro större än fodret, rödletta, den senares af fodrets längd, hvita.

Desmekattost, se Desma.

Rosenkattost (M. Alcea L.), med större, blekröda blommor i toppen; skild från Desmekattosten genom glatta frukter.

Röd Kattost (M. silvestris L.), med hög, upprätt stjelk, högröda blommor i bladvecken.

Kors, hvilken stat utaf vaggande stänglar,

Smörblomster, kattost och gräs i parti! DAHLGREN 1: 397.

Törel.

+ Kattpattar, m. pl., Skåne =

+ Kattrumpa, f. Benämningen, i likhet med alla dylika parabler obrukbar sôriq, växtnaiłn, tillägges de mest skilda vảxter, såsom Småborre, Mörkt Kungsljus, Ax-ärenpris $\mathrm{m}$. $\mathrm{fl}$.

+ Kattstöflar, m. pl.= Gulhvifva och (enligt Linnés Sk. resa 210) äfven Höskallra.

Kautschu, m., ett segt, slemmigt växtämne, som erhålles af flera mjölksaftiga träd, företrädesvis af Siphonia elastica Pers. i Sydamerika.

Kax, Käxa ingå som stamord i Hundkax, Hundkäxa och som artnamn i Kaxstäkra. Förekommer i många former $\mathrm{i}$ det Engelska folkspråket.

+ Kejpe, Kep (af Lat. Cepa), m., Gotl. och Boh. en art Lök. Se Lök.

Kejsarkrona, f, en praktfull lökväxt af slägtet Kronlilja, med en bladtofs i spetsen, frán hvilken de klocklika kronorna nedhänga: Fritillaria imperialis L. - nKejsarkronor måste växa här (Simbris) frodigare än på något annat ställe i riket, ty de voro satte på hvar enda stol i kyrkan vid pingesthelgen, så att hela kyrkan var dermed majadn. Linnés Sk. resa 141.

Kers, m., Vesterg. blomvippan af Kase (Vass).

Kikbår, n., bärlika utväxter på En, förorsakade af en liten -insekt (Tipula juniperina), hvilka af allmogen ansetts som medel mot kikhosta.

$\div$ Kik i rammen, Ångerm. = Konvalje.

Kikärt, f, en i södra Europa odlad ärtväxt: Cicer arietinum I. Äfven denna benämnes Kaffevicka (se der).

$\div$ Killingblomma, f., Gotl. = Blåsippa.

Kina, se China.

Kirs, Kirskål, m., ett mycket gammalt namn på Qvaller. I äldre Tyskan Giersa, nu Giersch.

$\div$ Kivelbast, $\mathrm{n}$., Roslagen $=\mathrm{T}$ ibast.

† Klammer-ris, n., en växt, som, kastad under bordet i gästabudslag, anses vålla gräl och slagsmål. Sådana mystiska namn föras pà olika orter till olika växter; det här ifrågavarande tillägges i Småland Sqvattram, hvilken genom sin starka narkotiska lukt möjligen kan bidraga till att åstadkomma omförmälda verkan, men vanligen föres det likväl till den milda Gulmåran.

Klasbär, Roslagen = Stenhallon. Klason, se Koddon.

Klett, m., n., torde vara Blåklintens rigtigaste benämning, eller, med artnamn, Blåklett, såsom den $\mathrm{i}$ Östergötland och flerstädes kallas. Se Blåklint.

Säden förgicks; karbòrren och klettet Bredde sig ut till en skog.

ADLERBETH 58 .

Rödklett (Centaurea Jacea L.), se Knoppört. 
Klilaf, se Laf.

$\div$ Kling-ris, n., Vesterbotten $=$ Dvergbjörk.

Klint, Rödkliut, m., en prydlig röd blomma af Näglikefamiljen, känd genom sitt läderartade blomfoder med långa flikar: Agrostemma Githago L. Allmän bland vintersäd. "Skånske slättbonden ... anser den rag, hvari mycken klint finnes, för den drygaste i hushăllet». RETZIUS 1: 28 .

Klintblära, f., ett med Klinten närförvandt örtslägte, med uppblåst blomfoder, enkönade blommor: $M e$ landrium ROEHL.

Klippglim, m., Silene rupestris $\mathrm{L}$. Klocka, se Blåklocka.

Klocklilja, f., ett slägte bland Narcissväxterna, med klocklik, sexbladig kalk, likformiga kalkblad: Leucojum L. Se Snöklocka.

\section{Klockljung, se Ljung.}

Klockrofva = Rapunzel.

Klock-stålört, se stålört.

Klofibla, f., ett med Hökfiblan närförvandt örtslägte, med upptill afsmalnande frukter och tillbakaböjda bladflikar: Crepis L. Jfr Fälle.

\section{Klofving, se Klöfver.}

+ Klotblomma, f., ett efter Latinet nybildadt namn på Globularia vulgaris L., men obehöfligt, då vi förut ega tvenne inhemska: Berg-skrabba och Blåboll.

Klotboll, m.,svampslägtet Sphoerobolus Tope; ett mycket passande namn, men svampen är oansenlig, hvarföre jag tvekar om det bör upptagas.

† Kloting, m. = Furgräs.

+ Klotsvamp, utgår alldeles.

Klottång, Bohuslän, se Tång.

Klovicka, f., en liten, hos oss sällsynt ärtväxt, med klolika, ledade ärtbaljor. Fogelklovicka: Ornithopus perpusillus $\mathrm{L}$.
Kloärt, f., ett örtslägte bland Ärtväxterna, länge förenadt med Backsöta, men skildt genom blomkölens förlängning till en udd eller liten klo, hvarföre namnet måste tilläggas $O x y$ tropis Dec.

Klubbfibla, f., en art af slägtet Arnoseris (A.pusilla $\mathrm{G}$ serтs.), skild från alla öfriga Fibleväxter genom sina upptill klubblikt svälda stänglar.

Klubbgrås, n., Österbotten, ett synnerligen passande namn på slägtet Kasedun. Högst olämpligt har man gifvit benämningen Klubbgräs åt Sandborsten.

Klubblaf, se Laf.

+ Klyfblad, n.; ett af mig fordom illa bildadt namn på svampslägtet $S c h i$ zophyllum $\mathrm{F}_{\mathrm{r} .}$, hvilket bör utgå. Skulle man anse ett Svenskt namn nödigt, kunde det lyda Klyftsvamp.

\section{† Klådblomster, se Skabb-blom-} ster.

Klådxis (efter Norskan), n., en hos oss endast vid Indalselfven växande buske, som liknar Cypressen: Ifyricaria germanica Desv.

+Klåkunta, se Blåeld, Blåkunta. Klöfver, äldre namn Klofving, $\mathrm{m}$. (origtigt Klöfvergräs), en i folkspråket allmän benämning på växter med af trenne småblad sammansatta blad, och sannolikt ursprungligen = Bläcken (Menyanthes L.), ty Trifolii äldsta namn äro Väpling och Kolla. Numera är Klöfver en så allmänt antagen benämning för slägtet Trifolium L., att rättelse vore fruktlös. Klöfver ingår tillika i många andra växtnamn, såsom Klöfverärt, Honungsklöfver, Kråk-klöfver m. fl., hvilka särskildt upptagas. - I nuvarande skriftspråk är Klöfver, som sagdt, slägtet Trifoli$u m$, ärtväxter med blommor i ett rundt hufvud och med små, mest enfröiga, inom fodret slutna fröbaljor. Såsom i 
ekonomiskt afseende vigtiga, måste de allmännare arterna anföras:

Alsike-klöfver (bättre efter'Tyskan Svensk Klöfver), med uppstigande stjelk, rödhvita blommor: T."hybridum I. Ypperlig foderväxt.

Back-klöfver, med upprätt stjelk, hvita blommor: T. montanum L.

Gullklöfver, Humleklöfver, upprätt, med gullgula blomhufvud: $T$. agrarium $\mathbf{L}$.

Harklöfver, upprätt, ettårig, med hvitulliga blomhufvud: T. arvense $\mathrm{L}$.

Hvitklöfver, med krypande stjelk, hvita blomhufvud: $T$. repens $\mathrm{L}$. Odlas till bete.

Rödklöfver, med upprätta stjelkar, röda blommor: T. pratense L. Den förnämsta bland våra odlade foderväxter.

Skogsklöfver, med hit och dit böjda stjelkar, högröda blommor: T. medium (L.). Kallas äfven Bergklöfver.

Vattenklöfver $=$ Bläcken.

Klöfver-snarrefva, se Snarrefva. Klöfverärt, f., ett med Klöfver närförvandt slägte, men med långa, flerfröiga, fyrkantiga ärtbaljor: Tetragonolobus Soop.

Spergelklöfverärt (T. purpureus Joevcu), med röda blommor; odlas under namn af Spergelärt.

Strandklöfverärt $(T$, siliquosus Rоти), med gula blommor; växer vild.

Knagel, m., enligt Ihre ett namn på Pors.

Knagglestarr, se Starr.

Knapp-ag, m., ett med Ag förvandt slägte, med alla småaxen i ett hufvud: Schoenus x.

Knappar, m. pl., benämnas flere växter med plattade blomhufvud, företrädesvis Vädd-arter, äfven Monke och mer oegentligt Knoppört.

+ Knappfjäll, n., ett àt små mikroskopiska svampar gifvet namn, som ej förtjenar upptagas.
Knappsåf, f., ett slägte bland Halfgräsen, med ett enda ax, utan fröull: Eleocharis R. Br. Alla arter af Knappsäfven växa på fuktiga ställen. Se Sälta.

Knapptåg, se Tåg.

Knapptång, se Tång.

Knappvädd, se Vädd.

+ Knarfvel, m., ett mig obekant namn på Frälicen.

Knavel, m., örtslägtet Scleranthus L., små växter med ledade stjelkar, trinda blad och små, kronbladslösa blommor. "Knafvel blommade och dess innerste blomsträngar lutade tillsammans åt sina styftor». Linnés Öl. resa 18. - Namnet Knawel finnes redan hos de äldste Tyske botanister. Franckenius, Tillandz och Bromelius ha Knaflegräs.

\section{Knoppgräs = Stor Knoppört.}

Knoppört, f., örtslägtet Centaurea L., tillhörande Tistelväxterna (men våra inhemska arter äro icke taggiga), med strutlika strålblommor. De flesta arterna hafva sjelfständiga namn och upptagas derföre särskildt, såsom Blåklett eller Blåklint, Gulskära, Jernört, Storhufvud (Stor Knoppört).

Knutarv, m., en liten med Rödarven beslägtad ört, blott afvikande genorn blommornas fyrtal: Centunculus minimus L. Namnet föres af Wahlenberg till spergel.

\section{Knylbräcka, se Bräcka.}

Knylhafre, m., en vild, mångårig, men som foderväxt odlad art af slägtet Hafre, med knölig rot: Avena elatior $\mathbf{L}$.

Knylklocka, se Blåklocka. Knyl-solöga, se Solöga. Knylvippärt, se vippärt.

Knytling, m., en liten, till jorden nedtryckt ört, med gröna, till små knyten $i$ bladvecken gyttrade blommor: Herniaria glabra L. Knytlingen frodas, fast han dagligen trampas. 
† Knäckegrås, Skåne = Fräken. Knäckepil, se Pil.

Knägrås, n., ett litet, nedliggande, knäböjdt gräs med mångblommiga småax: Triodia decumbens P. BEAUv. Knägräset växer på magra betesmarker, liksom förtryckt bland de andra gräsen.

Knärot, f., en ört af Nosseväxternas familj, med knäböjda rötter och hvita, ensidiga, något vridna blomax: Goodyera repens R. Br. Den mossbelupna marken i de dystra barrskogarne upplifvas af Knärotens hrita blomax.

† Knöltång, se Tång.

Knöple, n., egentligen benämning på fröhusen hos Lin, men äfven på lågväxt lin, samt på någonting förkrympt, hvaraf växtnamnet Jord-knöple (se detta).

Kobeber, Kubeber, m., en art peppar af Piper Cubeba I. rIL. Föga brukligt namn.

† Kobär, n., Skåne = Stenhallon.

†Koddon, äfven Klason, n., enligt Linné benämning i Småland på Stenhallon; jag har dock der hört endast namnet Stenbär.

Kohvete, Korphrete, Pukhvete, $n$. , năgra bland de mångfaldiga namn, som tilläggas Akerkovall. (Af misstag hänföras namnen till Ängskovallen.)

Kokelkärnar, m. pl., bären af Menispermum Cocculus L. (från Malabar) samt flera arter af slägtet Cocculus Deo.

Kokosnöt, f., frukten af Kokospalmen (Cocos nucifera L.) på Söderhafvets öar.

Kolbrand, se Brand i säd.

Kolfvåxter, Etthjertbladsväxter med han- och honblommor på olika kolfvar af samma stånd, utan hölster eller täckfjäll: Typhacere Sx. Irr. Hit höra Igelknopp och Kafveldun.
Kolla, f., ett $\mathrm{i}$ Vestergötland antaget slägtnamn på Klöfver. Hvitkolla, Gullkolla, Rödkolla motsvara Hvit-, Gull-, Rödklöfver.

Kolumbo,m.,en medicinsk drogue, som erhålles af Cócculus palmatus DE. från södra Afrika.

Kolvass, m., Upland = sjösäf, så kallad för sin mörka färg, i motsats till Skärvass. (Må ej skrifvas Kålvass.)

+ Komjan, m., Skåne = Kummil.

Konig, Koning, m., ett uråldrigt, dyrbart namn på Origanum vulgare L., tillhörande Sugeväxterna, med i en vippa hopklasade småax, men ingen jemn qrast såsom hos Dostan. Namnet härleder sig knappt från konung, ehuru det i Småland uttalas Konungsgräs. Efter Tyskan har man kallat växten Dosta, men detta namns härledning visar uppenbart, att det ej kan föras till Koning. Jfr Dosta.

Konvalje (äfven Liljekonvalje, Lille Kovalle; efter det Latinska Lilium convallium), m., en Liljeväxt med breda rotblad, hvita, klocklika, i en klase sittande blommor på bar stängel, samt bär: Convallaria majalis $\mathrm{L}$. Namnet förekommer först hos Bromelius (1694); förut kallades växten Rams och Majlilja. Konvaljens' blommor utmärka sig genom sin vällukt, dess blad genom sin glans.

† Kopattar, m.pl., Skåne=Elockljung.

$\div$ Kopiss, m., Vesterg. = smörblomma. Utgår af många skäl.

+ Kopplaf, utgår, 'se Laf.

+Korall-laf, utgåx, se Laf.

Korallrot, f., en bladlös ört af Nosseväxternas familj, med korall-lik rotstock: Corallorrhiza innata R. Br.

Korgpil, f., en art af Bandpil med mycket smala skott och blad: Salix viminalis $\mathbf{L}$. 
Stundom bereder han rankorna band af böjelig korgpil,

Flaitar med händig flit af buskarnes telningar korgar. ADLERBETH 62.

Korgsvamp, m., se Brödkorgsvamp.

Koriander, m., en odlad Ümbellat; med klotrunda frön och stark, vidrig lukt: Coriandrum sativum $\mathrm{L}$. Mycket använd kökskrydda.

Korinter, m. pl., en afart af Vindrufvan, med mycket små frukter: $V_{i}$ tis vinifera $\mathbf{v}$. apyrena $\mathrm{L}$.

Kork, m., barken af en art Ek i södra Europa: Quercus Suber L. (Korkek).

Korkalm, se Alm.

Korksopp, m., rätteligen Björkticka.

Korn, n., i vidsträcktaste mening: frön och mindre frukter, t. ex. pepparkorn; men i inskränktare: sädesslagens frön, och i speciell: Bjugg (Hordeum r), i hvilken mening benämningen nästan uteslutande användes i riksspråket. Deraf odlas, utom mindre anmärkningsvärda förändringar, följande arter:

Allmänt Korn ( $H$. vulgare L.), med axets korn sittande i sex rader, af hvilka två äro tilltryckta axfästet; alla blommorna tvåkönade med borst.

Gumrik-korn, Gumringkorn ( $H$. distichum $\mathrm{L}$.), med hanblommor på de platta sidorna af axet, utan borst, frön öfver hvarandra liggande. Kallas äfven Flätting.

Himmelskorn' (H. hexastichum L.), likt Allmänt Korn, men alla raderna äro liká utstående. Kallas äfven Sexradigt Korn.

Skyffelkorn (H. Zeocriton L.), likt Gumrik-korn, men kornen äro utspärrade med långa borster.

+ Kornblomma, Kornros, obestämda namn, tillagda åtskilliga bland säd växande örter, t. ex. Blåklett, Gullkrage, Rödklint.
Korndodra, f.; en ört närförvandt med Dodra,' med hvilken den ock af Linné förenades, men har enfröiga skidor: Neslia paniculata DEsv.

Kornell, m., ett slägte innefattande både buskar och örter; det kommer nära Måraväxterna, men kronbladen äro fria. Atskilliga arter planteras som prydnadsväxter. Här upptaga vi.blott:

Röd Kornell (Cornus sanguinea I..), buske med röda grenar, blommorna hvita, utan svepe. Växer vild i Göta rike. (I Vesterg. Eknas.)

Äkta Kornell (C. mascula L.), buske, blommande på bar qvist, blommorna gula, med svepe. Vild i södra Europa, odlad i Sverige.

Den örtartade Cornus suecica L. se Hönsbär.

Kornfibla, f., en till Fibleväxterna hörande ört (Scorzoner humilis 4. .), med lancettlika, vid torkning svartnande blad och stora, af hvitulliga och vanligen ogrenade stjelkar uppburna, gulblommiga korgar. Jfr Scorzoner-rot.

Kornros = Blåklint.

Korntagg, se Brandkorn.

Kornvalmo, se Valmo.

† Korp, Korphrete, se Kohvete.

+ Korsblomma, Kristi Korsblomma $=$ Passionsblomma.

Korsblomstrige, en stor och högst naturlig växtfamilj, med fyra i kors sittande fria foder- och kronblad, sex ståndare, af hvilka två kortare, och tvåskalig skidfrukt: Crucifer a Adxs. Efter folkets uppfattning kunna de fördelas i Kålväxter, med långa, smala skidor och vanligen gula blommor, Krasseväxter, med korta, breda skidor, och Fioler, med fioletta blommor. Dock finnas flere, som icke kunna föras till någondera gruppen, eller som snarare tillhöra båda de sistnämnda (t. ex. Ängkrassen).

+ Korsbläcker, f. pl., se Bläcken. 
Kors-kovall, se Kovall.

†Korskål, m., uppgifves som benämning på Svalört (Ficaria Roxn), men då denna icke erbjuder någon anledning till namnet, måste det bero antingen på missförstånd eller ock på misskrifning i stället för Kirskål.

$\div$ Korsnäta, f., Vesterg. = Hvitplister.

Korsört, f., de ettåriga arterna af slägtet Boört (Senecio L.), med inskurna, flikiga blad och inga eller ock korta, tillbakarullade strålblommor.

$\div$ Korsört benämnas ytterligare 1) Ormbär i Bleking; 2) Kors-kovall i Jemtland; 3) slägtet Dån enligt Wahlenberg.

Kosmör, se smäre.

Kosopp, Kosvamp, m. (origtigt Koticka), âtskilliga arter af slägtet Rörsopp, i synnerhet Boletus luteus, granulatus och bovinus L., eller arter öfverdragna med ett segt slem, hvaraf man antagit, att efter deras förtärande af korna mjölken skulle blifva seg. Se Linnés Vestg. resa 274.

Koträd, n., ett i Guyana växande träd (Taberncemontana utilis $\mathrm{ARx}_{\mathrm{R} .}$ ) med ymnig hvit mjölksaft, hvilken är mild och förtäres som mjölk.

Kovall, m., örtslägtet Melampyrum L., hörande till Skeplingsväxterna, utmärkt genom blott ett frö i hvartdera af fröhusets rum. Hithörande arter hafva i folkspråket flera namn, hvilka särskildt upptagas.

Korskovall (M. cristatum L.), med blommor i fyrkantiga ax.

Lundkovall (M. nemorosum L.), med blå, tandade blomskärmar. Utmärkt vacker.

Akerkovall (M. arvense L.), med blommor $\mathrm{i}$ allsidiga ax, röda, parflikiga skärmblad.

Skogskovall (M.silvaticum L.) och Ängskovall (M. pratense L.) hafva blommorna parvis och ensidigt sit- tande i bladrecken; den förres äro öppna, höggula, den senares shutna, hvitgula.

Anm. Om ordformen vall, se Via.

Krageblomma, f., örtslägtet Chrysanthemum L., tillhörande Blomhålksvästerna, uttmärkt genom (sina sköna, tunglika strålblommor omkring den platta, af pipiga blommor bildade disken.. - Ordet blomma bortfaller i sammansättningar.

Gullkrage, m. (Gul Krageblomma), med gula strålblommor: Ch. segetum L. Jfr Solsicka.

Prestkrage, m. (Prestkragebiomma), med hvita strålblommor: $C h$. Leucanthemum $\mathrm{L}$.

Krakmandel, m., mandelkärne innesluten i sitt skal. Se Mandel.

Krampfrö, n., frön af Åker-rättikan, inblandade i säden, hvilka ansetts förorsaka kramp, dragsjuka. Namnet Kramprättika (hos Dalin) är obrukligt, öfverflödigt.

Kransborre, m., tillhörande Sugeväxterna, med hrita blommor, som bilda klotrunda kransar omkring stjelken: Marrubium vulgare L. Se Andorn.

† Kranshirs, m., obrukligt, olämpligt namn; kallas rätteligen Kafvelhirs.

+ Krans-ormbunke utgår alldeles.

Kransårt, se Ärt. Jfr Kronärt.

Krapp, m., ett örtslägte bland Måraväxterna, kändt af sina klocklika kronor. Den hos oss för färgerier odlade växtens rot lemnar ett rödt färgstoft: Rubia tinctorum L.

\section{Kraslaf, se Laf.}

Krasse, m., örtslägtet Lepidium L., tillhörande de Korsblomstrige, med runda, platta skidor och enfröiga rum. I folkspråket ingår krasse i en mängd andra slägtnamn, hvilka särskildt upptagas. Äkta krassearter äro: 
Allmän Krasse (L. sativum $\mathrm{I} . ._{\text {. }}$, allmänt odlad för sin behagliga krassesmak. Bladen mångklufna.

Bitterkrasse ( $L$. latifolium L.), med breda, glatta, odelade blad. Kallas $\mathrm{i}$ gamla bibelöfversättningen (2 Mos. 12: 8) Bittersalsa.

Fältkrasse ( $L$. campestre R. Br.), med odelade, pil-lika, ludna blad.

Gatkrasse ( $L$. ruderale L.), liten, med parflikiga rotblad.

Indiansk Krasse, se Skölding.

Krasse-sommargyllen, se Sommargyllen.

+ Kratstistel utgår. Torde hafva uppkommit genom skrif- eller tryckfel.

Kremla, f:, ett slägte bland Skifsvamparne, hos hvilket skifvorna äro lika lănga, utan inblandning af kortare: Russula $\mathrm{Fr}_{\mathrm{r}}$. Kremlorna äro i allmänhet giftiga.

Krepling (krypande Ljung), m., en liten, nedliggande buske, tillhörande ljungväxterna, med sambladig krona och fem ståndare: Azalea procumbens $\mathrm{L}$.

Krikontråd, n., en art af slägtet Slån, med svartblå, runda, välsmakande frukter: Prunus insititia L.' Kallas äfven Tysk slån.

Kringelväxter, Svenska benämningen på familjen Umbellatce $\mathrm{I}_{\star}$, men vi hafva i detta arbete begagnat namnet Umbellater, såsom mera kändt.

Krist-torn (pl. -törnen), n., en buske med läderartade, taggiga, städse grönskande blad: Ilex Aquifolium $\mathrm{L}$. Kristtörnen växa vilda på Jutland och i sydvestra Norge, men uthärda ej på fritt land våra vintrar.

\section{Kroll-lilja, se Lilja.}

Kron-artskock, se Artskock.

Kronill, i Dalins ordbok felaktigt för Koronill. Se Kronärt.
Kronlilja, f., ett utmärkt örtslägte, tillhörande Liljeväxterna, lätt igenkändt af en honungsgrop vid kronbladens bas: F'ritillaria L. (Lilja bortfaller i sammansättningar.) De mest bekanta arterna äro:

Kejsar-kronlilja $=$ Kejsarkrona.

Kungs-kronlilja, äfven Kungskrona, Kungslilja, Kungsängslilja, Damspelslilja: $F$. Meleagris L.

Kronsporreväxter, Tvåhjertbladsväxter med två små foderblad, fyrbladig, oregelbunden blomkrona, det nedre kronbladet utskjutande en sporre: Fumariacece Dec. Hysa vattenaktig saft.

Kronärt, f. 1) En på Öland och Gotland växande vacker buske, tillhörande Ärtväxterna, med ledade fruktbaljor: Coronilla Emerus L. - 2) En förändring af våra vanliga Ärter, med i krans sittande blommor. Benämnes rigtigare Kransärt.

Kropp, m., en af våra prydligaste vilda växter, med hög, mångbladig stjelk, lång, purpurröd blomspira: Epilobium angustifolium L. eller Chamonerion angustifolium Scop. "Kropp var i rågåkrarne vid Rinkaby det svåraste ogräset», Linnés Sk. resa 78.

Anm. Ingen Svensk växt torde hafva så många namn som denna. Bland dem eger Kropp bestämdt företräde, så väl såsom ett sjelfständigt namn som för sin härledning af Ang.Sax. krop, spica. Linné, Retzius, Wahlenberg och alla författare, som förtjena auktoritet, sätta ock detta främst.

Kroppväxter, Tvåhjertbladsväxter med mycket olika utseende, men hos alla sitter fruktämnet under blomkronan, de fria kronbladen och ståndarne äro fästa i fodrets svalg: Onagrarice Juss. Hit höra Kropp, Dunört, Hezört m. fl.

† Krukört, f., ett kostligt exempel på huru af missförstånd de besynnerligaste namn uppkomma och sedan slafviskt afskrifvas. Af ett gammalt och 
ännu i folkspråket brukligt namn $K \ddot{a}$ ring-ruka gjorde man först genom felaktig stafning Kärin-kruka, och af kruka i stället för ruka (stercus) har man sedan tillskapat Krukört.

Krus- ingår $i$ en mängd växters benämningar såsom artnamn, $t$. ex. Krusmynta, Krustistel m. fl.; äfven till betecknande af artförändringar, $t$. ex. Kruskål, Krusrenfana, Krussallat m. fl.

Krusbräken, $\mathrm{n}$., ett slägte bland Bräkenväxterna, med de ofruktsamma bladen krusiga, men de fruktbärande hela: Allosorus crispus Bersm.

Krusbär, n., en förändring af Stickelbär, med styfhåriga frukter: Ribes Grossularia L.

Krusfrö, n., hos Bromelius (ej Kruffrö, såsom i Bot. utfl. 3: 243 uppgifves): Selinum Carvifolia L., med mycket sammansatta blad och flikiga småblad. Namnet har väl afseende på frönas upphöjda åsar.

Kruskål, se Kål.

Krusmynta, se Mynta.

Kruspersilja, se Persilja.

Krustistel, se Tistel.

Kruståda, Kruståtel, se Tåda.

Krutbrånnare = Svedt Nyckel-

blomster. nKrutbrännare, ett namn; som är makalöst väl gifvet, ty axet har röda blommor såsom eld, men på spitsen små outslagna svarta blommor, hvarmed branden aftecknasn. Linnés öl. resa 115.

Krutläskare, $\mathrm{m}$. = Kafveldun. nKrutläskare kallade folket (i Marstrand) ej obeqvämligen den bekanta Typha, ty hon liknar det instrument, med hvilket man läskar stycken» (kanoner). Linnés Vestg. resa 181.

Krydda, f., kallas af allmogen i synnerhet för vällukt odlade växter. Platsen, der dessa odlas, benämnes kryddsäng, och blomsterqvastar, som - pläga bindas om söndagarne, kallas kryddqvastar.
† Kryddböna, f., kärne af Ocotea Puchury $\mathrm{H}_{\mathrm{ART}}$, från Brasilien. Officinell.

Kryddmynta, f., en ettårig, med Mynta beslägtad ört, men med ensidiga ax: Elsholtzia cristata Wruz. Kryddmyntan är införd från Sibirien och nu flerstädes förvildad. Har stark kryddlukt.

Kryddnäglika, f., de torkade blomknopparne af Caryophyllus aromaticus L., ett ständigt grönskande träd på Moluckerna.

Kryddpeppar, m., de torkade bären af Eugenia Pimenta Dzo., ett ständigt grönskande träd i Vestindien.

Krypböna, se Böna.

+ Krypfloka, se Kärrfloka.

Kryphyen, se Hren.

Kryptåg, Juncus bufonius'L.

Krypvide $=$ Jordvide.

† Kråkbjugg, Kråkhvete, Kråk-korn (Smål.) tillhöra Björnmossans många benämningar.

Kråkbär, se Kråkris.

Kråkfötter, m. pl, ett namn tilllagdt de mest skilda växter, såsom Kråk-klöfver (Rosl.), Bläcken (Vesterg.), en art af Alant, Inula salicina L. (Gotl.), Flikigt Groblad (Plantago Coronopus L.) och Kråk-krasse.

Kråk-klöfver, m., en mångårig ört, närbeslägtad med Fingerört, men med nedliggande stjelk och rödbruna blommor, växande i kärr: Comarum palustre $\mathrm{L}$. Se Linnés Sk. resa 359.

Kråk-kiasse, m., en liten Krasseväxt, med enfröiga, knöliga, icke uppspringande skidor: Coronopus depressus Morscr. - Af Wahlenberg benämnes den Kråk-klor.

† Kråklök, m., Nerike = Vårlök.

Kråkxis, n., Kråkling, m., en Ljung liknande buske, men med tre- 
bladiga blommor och svarta bär: $E m$ petrum nigrum L. Frukterna kallas Kråkbär, Kräkion, Skräkon. Kråkriset är en af de mest härdiga växter mot köld. - Kråkbären blifva i högsta Norden smakligare och, ätliga (Wahlenberg).

Kråksyra, se syra.

+ Kråktorn, Kräketorn, n., ett af de många namnen på Vägtorn.

Kråkvicka, se Vicka.

+Kråkärt, f., ett namn som tilllägges flere Ärtväxter, vanligast Kråkvickan, men i Österg. Vårvippärten.

Kråkört, f., Skåne = Tätört.

Kräftstenslaf, se Laf.

Kräkel, m., Gotl., en Tångväxt med trinda, jemnhöga grenar: Furcellaria fastigiata Hons.

Kräkling, Kråkon, se Kråkris. Kräkrot = Ipecacuanha.

Krösonris, n., den i Göta rike vanligaste bẻnämningen på Lingonris. Frukten kallas Krösa, Kröson, Kröser.

Kubbhvete, n., en art Hrete med ludna småax utan borst: Triticum turgidum L.

Kulla, f., ingår i mångfaldiga provinsnamn på växter i stället för blom$m a$; äfven i antagna slägtnamn, såsom Brunkulla, Grönkulla.

Kullor (plúr. af Kulla), i bestämd mening örtslägtet Anthemis L., tillhörande de Hålkblomstrige växterna och liknande Krageblommor, men med fjälligt blomfäste. Hit hörande arter äro allmänt bekanta :

Letkullor (A. tinctoria L.), med gula strålblommor. Kallas äfven Färgkullor; af Tillandz Gula Letblomster, af Wahlenberg Lettblomster.

Surkullor (A. Cotula l.), med hvita strålblommor. Likna Kamillblommor, men hafva vidrig lukt. (Falskeligen hitföres Baldersbrå.)
Åkerkullor (A. arvensis I.), likna de näst föregående, men äro utan lukt.

Kummer, m. 1) Blomhängena på Hängeväxterna, företrädesvis̀ på Al och Björk. 2) Ortslägtet Geum L., tillhörande Brumväxterna, hvars småfrukter sluta $i$ en lång borst.

Fårkummer (G. rivale L.), med större, hängande, rödbruna blommor.

Näglikekummer (G. urbanum L.), med mindre, upprätta, gula blommor.

Kummil, Kummin, m. Under detta namn förvexlás två olika växter, nemligen 1) vår inhemska Karv ( $C a$ rum Carvi L.), som nu vanligen kallas Kummil, och 2) en i södra Europa förekommande snarlik växt, Cuminum Cyminum L., hvilken namnet Kummin rättast tillkommer. Redan Harpestreng kallade den förra Dansk, den senare Tysk Kummin. Som nu intet hopp är att lyckas återinföra det äldre namnet Karv, vore lämpligast att benämna $C a$ rum (i likhet med Tyskarne) Kummil och Cuminum Kummin.

+ Kungsbär, Österg. = Måbär.

Kungskrona, Kungslilja, Kungsẳngslilja, se Kronlilja.

Kungsljus, n。, ett allmänt örtslägte, med platt, oregelbunden krona och fem olika långa ståndare: Verbascum L. Dess inhemska arter äro:

Filtbladigt Kungsljus (V.Thapsus L.), med ulliga, på stjelken nedlöpande blad, gula blommor.

Hvitt Kungsljus (V. Lychnitis L.), med hvita blommor.

Mörkt Kungsljus (V. nigrum L.), med skaftade blad, ståndarsträngarne brunludna.

Kungsspira, Kung Carls spira, f., en ståtlig ört af slägtet Frier, med tillsluten mynning: Pedicularis Sceptrum Carolinum L. Kallas Kungsspira i Vesterbotten, Myrkong i Jemtland. Tillegnad konung Carl XI af O. Rud- 
beck d. y., med namnet Sceptrum Carolinum:

nHvars blomma, lik en hjelm, så gul som gullet ljser,

Med blek och blodig mun samt blod-

$\div$ Kuplaf utgår. bestänkta blad».

Kurbits, m., se Pumpa.

Anm. Profeten Jonas Kurbits kan ej med säkerhet föras till någon växt; man har gissat dels på någon Gurkväxt, dels på Ricinus L. Sannolikt är den en idealiserad ranka,

Kyndel, m., ett efter det Tyska Quendel i skriftspråket upptaget namn på Satureja hortensis L., en odlad kryddväxt med trenne samsittande blommor, af Sugeväxternas familj. Tyskans Quendel är dock egentligen Timjan, och Kyndeln har ett äldre, bättre namn i folkspråket: Safver.

Kål, m., 1) i inskränktare mening en bekant, odlad köksväst: Brassica oleracea L., af hvilken man eger mångfaldiga förändringar, frambragta genom kultur, såsom Blomkål, Blåkål, Hvitkål eller Hufvudkål, Kruskål m. fl., hvilkas närmare bestämning tillhör trädgårdsspråket; 2) i vidsträcktare mening icke blott samtliga arter af Kålslägtet, såsom Rapsat, Rofva m. fl., utan ock Korsblomstrige växter med gula blommor eller kål-lika blad, såsom Dufkål, Strandkål, Ängkål m. fl., hvilka särskildt upptagas. - 3) Kål kallas äfven örtståndet af flere växter, t. ex. Potatiskål, Rofkål, i synnerhet sådana som tjena till grönkål, t. ex. Fruekål, Hässlekål, Nässlekål. I denna mening förekommer Kål $\mathrm{i}$ bibeln: nden-som svag är (i tron), han äter kål». Rom. 14: 2.

Kålfro̊svamp, m., en svampväxt, som alldeles liknar kålfrö och stundom i stor mängd finnes på dylika frön, hvilka under vintern vissnat: Sclerotium Semen Tone. Af allmänheten anses Kålfrösvamparne ofta för verkliga kålfrön.
Kålpalm, f., ett slägte bland Palmträden, utmärkt för sin utomordentliga höjd: Areca oleracea L. De outrecklade bladknopparne användas som kål.

Kålrabbi, m., se Rotabagge, Kålrot.

\section{Kålranunkel $=$ Svalört.}

Kålrot, f., en kålart med rötter. liknande rofvors: Brassica Napobrassica L. Jfr Rofkål, Rotkå!.

Kålsat, m., en odlad förändring af Akerkålen, Brassica campestris I.

Kålsenap, m., ett örtslägte, som står midt emellan Kål och Senap, förenadt än med den ene, än med den andre, skildt genom i tvenne rader sittande frön: Diplotaxis Drc. De hos oss växande arter af Kålsenapen äro förvildade, införda med barlast.

Kåltistel, se Tistel.

Kålvass, skriffel för Kolvass.

Kålväxter, se Korsblomstrige.

+ Kåpört, f., ett af botanister bildadt namn efter folkspråkets Jungfru Mariæ kåpa.

† Kägrabuske, m., Hishult i Halland, enligt Osbeck= Sqvattram. Har ansetts som medel mot kikhosta, hvaraf namnet.

Källelunk, m., en liten ört, med motsatta blad, små hvita blommor, nedhängande, treskaligt, trefröigt fröhus: Montia fontana L. Af äldre författare hänföres namnet äfven till Ä.itgräset.

Källerhals, m., se Tibast.

†Källgräs, n., ett obestämdt namn; har i ordböcker blifvit fördt till Narfgräs (Catabrosa aquatica P. BEAvV.) och Källelunk. Utgår alldeles. Narfgräset växer ej i källor.

Källingbjörk, se Björk.

Källkrasse, m., en i källdrag växande ört af de Korsblomstriges familj, 
med parbladiga blad, hvita blommor och hettande krasse-smak: Nasturtium officinale $\mathrm{R}$. Br.

+ Kälört, f. (troligen misskrifning för $K a ̈ l l o ̈ r t$ ), okändt, obrukligt namn på Lonke. Utgår alldeles.

Kämpar, Slåsskämpar, m. pl., en i södra Sverige, Danmark och Norge allmän och derifrån till England (Kempes) införd benämning på en art Groblad, Plantago media I. Se Groblad.

\section{Kämpegrås, se Kampe.}

+ Känselblomma, f. Så kallas Mimosa sensitiva och pudica L., och benämningen kan tillämpas äfven på andra växter, som hopböja sina blad då de vidröras. Namnet äricke olämpligt, men jag bibehåller helst det Latinska Sensitiva.

+ Käringbär, n., Vesterg. = Blåhallon. Kallas äfven Käringhallon, och sjelfva busken benämnes i Skåne Käringtarmar; men i Halland öfverföres, enligt P. von Möller, detta namn till Akervindan.

Anm. De af Linné under Rubus ccesius anförda provinsnamn måste ytterligare granskas, emedan han länge förde till denna art äfven Rubus suberectus AxDERs. och plicatus TEтнE. Namneu Björnbär (Smål.) och Björnhallon (Österg.) tillhöra bestämdt de sistnämnda, icke $R$. coesius.

+ Käringfis, m., ett allmänt brukligt namn, som tillägges flere Röksvampar, i synrrerhet slägtet $L y$ coperdon Toukx. Kallas lämpligare Käringrök.

† Käringhallon, se Käringbär.

†Käringkål, 'm., Smål. = Kärleksört.

† Käringrock, m., Retzius = Brunört. Namnet är brukligt i Norge; = om i Sverige, har jag mig icke bekant. 구 + Käringruka, f. = Blåsuga.

Käringtand, f., ett af de mest mångtydiga och $\mathrm{i}$ formelt hänseende mest olärnpliga namn. På Öland föres det till Benveden (Linnés Öl.resa 126), i Skåne till Lonicera Periclymenum.L. (Linnés Sk. resa 319) och, liksom i Bleking, till Gulhvifvan (Sk. resa 240); men vanligen tillägges det Smäre och Gigelsärt, af hvilket senare namn ordet käringtand egentligen är ett slags öfversättning.

† Käringtarmar, m. pl., se Käringbär.

+ Käringöron, n. pl., Dalarne $=$ Daggskål.

† Kärinkruka, f, se Krukört.

+ Kärleksblomma, f., ett i Dalins ordbok upptaget namn på slägtet Nemophila Barr. från Californien, odladt bland prydnadsväxter. (Mig synes lämpligare att för dylika bibehålla de Latinska namnen oförändrade.)

Kårleksgräs, se Darrgräs.

Kärleksäpple, n. (efter Fr. pomme d'amour), en art af slägtet Solanum ( $S$. Lycopersicum L.). Odlas i södra Europa, och frukterna användas, som Kapris.

Kärleksört, f., en art af slägtet Fetknopp, med upprätt stjelk och breda, platta blad: Sedum Telephium L. Den afviker från öfriga arter så betydligt både till utseende och växtsätt, att den måste bibehålla sjelfständigt namn. "Allmogen har med denna örten hvarjehanda skrockn. RETZius $2: 670$. Om namnets härledning se Bot. utfl. 3: 242 not. Ett annat skrock med den samma anföres i Linnés Sk. resa 251.

Kärnfruktträd, naturliga familjen Pomacece L., skild från Stenfruktträden genom kärnhus, inneslutet i frukten, med flere kärnar (frön). Hit höra Apel, 0xel, Päronträd, Rönn m. fl.

Kärnlafvar, lafvar med slutna, vanligen svarta fruktvårtor, innehållande fröredningen liksom en kärne: Lichenes pyrenocarpi. 
Kärusvampar, svampar likartade med förenämnda Lafvar: Pyrenomycetes $\mathrm{Fr}_{\mathrm{R}}$.

Kärr: är ett af de vanligaste artnamn, t. ex. Kärrfrier, -fräken, -kafle (se Kaflegräs), -sälting, -tistel, -vial m. fl. Se slägtnamnen.

Kärrfloka, f., en liten Umbellat med krypande eller simmande stjelk och två-trestrålig blomflock: Helosciadium inundatum Kосн. Äfven kallad Krypfloka.

Körfvel (af Lat. Gerefolium), m. 1) Spansk Körfvel, ett slägte bland Umbellaterna, liknande Hundlokan, men med refflade frön: Myrrhis odorata Scop. 2) Svensk Körfvel, en art af Umbellatslägtet Anthriscus, liknande Persilja, men med släta frön : $A$. $C e-$ refolium Horrss. Scandix Cerefolium, $\mathrm{L}$.

Körne, n., "kallades här (i Skåne) både Prunus (spinosa) och Rosa (canina), som begge allmänt läggas på gärdesgårdarne, liksom sparr-ryttare, att afhalla kreaturen och nästan folket». Linnés Sk. resa 321.

† Körning, m., Vesterg. (enligt Ihre) $=$ Pors. Föråldradt och obrukligt namn.

Körs, f., Körsbårstråd, n., ett slägte bland Stenfruktträden, med i flock sittande blommor och rund sten inuti bären: Cerasus Touns. Af Allmänna Körsen (C.vulgaris Mruz.), med syrliga frukter, hafva vi talrika förändringar odlade, hvilkas urskiljande tillhör pomologiska arbeten. - En vild art är

Fogelkörs (C. avium MoENon), efter frukterna vanligen kallad Fogelbär. nKersebärsträ ... voro så höga som björkar och alldeles vilda, såsom andra skogsträn, och ingalunda planterade ; alla voro af Fogelbärsslagen, med stora blad och söt (svart) frukt»。 Linnés Vestg. resa 25.

Kösa, f., ett besvärligt, ettårigt åkerogräs, med yfvig, slak vippa och lång borst: Apera Spica venti P. BEAUv.
Lackfiol, f., en i äldre tider vanlig benämning på Löfkoja. Har äfven blifvit kallad Gyllenlack, d. v. s. Gyllne Lackfiol, hvarmed egentligen menades gul Löfkoja. - Vild Lackfiol, se Marfiol.

† Lacklök, m., enligt Wahlenberg. $=$ Löksuga.

Laf, m. (af Isl. la fa, hänga). Namnet tillkom ursprungligen endast de trådformiga, hängande slägtena (Usnea och Alectoria Acr.), men öfverföres nu till en talrik familj bland Groddtrådsväxterna, hvars rot, stam och blad äro förenade i en bål (lafbål), inneslutande ett lager af gröna korn. Genom dessa skilja de sig från Svamparne, och genom växtstället $i$ luften från Algerna. I det allmänna språket få de vanligen namnet mossa, och under detta såsom slägtnamn har redan Linné gifvit de flesta då kända arter Svenska namn; men benämningen Mossa är högst förvillande och maiste utbytas mot Laf. Denna växtfamilj, hvilken hos Linné utgjorde blott ett slägte (och väl alltid kommer att i folkspråket betraktas såsom sidant, med Laf till slägtnamn), fördelas nu $i$ en mängd slägten, men dessa äro ännu så litet stadgade, att jag anser olämpligt att gifva dem Srenska 
namn, helst som dylika benämningar icke gerna komma att ingå i folkspråket. Dalin har efter Liljeblads Flora infört $i$ sin ordbok slägtnamn på alla vid denne författares tid antagna slägten; men $i$ afseende på flera bland dem hafva sedan dess vidtagits sådana förändringar, att deras gamla namn numera dels icke brukas, dels äro föga lämpliga, och andra, t. ex. Variolaria (Kopplaf), Isidium (Korall-laf), Spiloma (Fläcklaf), Lepraria (Mjöl-laf) m. fl. hafva helt och hållet försvunnit. Vid sådant förhållande har jag här under Laf (som ingår äfven $i$ de nya slägtnamnen) upptagit endast de arter, som redan af allmänheten skiljas, t. ex. Islandslafven, Renlafven $\mathrm{m}$. fl., eller som med lätthet kunna eller ock för sin nytta förtjena urskiljas. De talrika andra arter med Srenska namn, som anföras under Mossa af Linné, under Laf af Liljeblad och Retzius, äro här med flit förbigångna.

Blodplättlaf, en hvit, mjölig skorpa, med coccionellröda frukter: $L e-$ canora hcemutomma Ácr. Färgväxt.

Blåslaf, skorplik, gul med rödbruna frukter: Lecanora ventosa Асн. Växer på stenar utsatta för vinden. Färgväxt.

Brosklafvar, lafvar med långa, smala bladflikar, likfärgade på båda sidor, och med ofärgade fruktskålar. Slägtet Ramalina A сн. Brosklafvarne lemna ett $\mathrm{i}$ teknik användbart slem; och de på sten växande äro rikt försedda med färgämne.

Bull-laf, en af de allmännaste arter, med hvitgrå skorpa och bruna, skållika frukter: Lecanora subfusca Acr.

Bägarlafvar, de bägarlika arterna af slägtet Cladonia Hoғrss., egentligen de brunfruktiga: C. pyxidata (L.).

Coccionell-lafvar, de rödfruktiga Bägarlafvarne: Cladonice cocciferce.

Enlaf, en höggul, bladig, uppstigande laf med sköldlika, bruna fruk- ter: Cetraria juniperina (L.). Växer på enbuskar.

Fäll-laf, en art af Nafvel-lafvarne, ofvan grå, under svartluden: Gyrophora vellea Aсн.

Gråstenslaf, den allmännaste lafven på sten, hvilken lik en grå skorpa, med svarta, insänkta skålar, öfvertäcker gråsten, liksom Kalklafven kalksten: Lecanora cinerea (L.).

Gull-laf, en af de allmännaste lafvar på träd, med bladig, utbredd, gullgul lafbål och likfärgade, skål-lika frukter: Parmelia parietina Acr. Äfven kallad vägglaf.

Hedelaf, se Islandslaf.

Hårlaf, en bladig art, med smala, uppstigande bladflikar, i kanten hårig, bruna fruktskålar: Physcia cilicris $\mathrm{Fr}_{\mathrm{r} .}$

Islandslaf, äfven kallad Islandsmossa, en bladig, upprätt, brun art, med rännlade bladtlikar och likfärgade, sköldlika frukter: Cetraria islandica Acu. Ett kraftigt näringsmedel och ett värderadt läkemedel i hektiska sjukdomar.

Jettelaf, en mycket bredbladig laf, ofran gulgrön, med skarlakansröda, njurformiga, sköldlika frukter på bladflikarnes undre sida: Nephroma arcticum Асв. Är den största af alla lafvar, känd under namn af Jettebröd.

Kalklaf, en på kalkstenar allmän art, med hvit, mjölig skorpa och svarta, insänkta fruktskålar: Urceolaria calcarea Ací. »Kalkmossa växte på alla kalkstenarn... (Linnés Vestg. resa 29) natt man endast genom henne kunde på långt håll skilja kalkstenar ifrån gråstenarn (Gotl. resa 183).

Klilaf, med bladig, smalflikig bål, ofvan grå, beströdd med groft kli, under svart: Evernia furfuracea $\mathrm{F}_{\mathrm{r}}$.

Klubblaf, en hvit, skorplikt utbredd laf med köttröda, klubblika frukter: Bceomyces roseus $\mathrm{P}_{\mathrm{ERS}}$.

Kraslafvar, spröda, busklika lafvar med släta, liksom lackerade grenar 
och klotlika frukter. Slägtet Sphcerophoron Pirrs.

Kräftstenslaf, en hvit, skorplikt utbredd laf med bleka skålar: Lecanora pallescens (ธ.). Dess på sten växande form, L. Parella (L.), är vigtig som färgämne.

Landkartelaf, en vacker, gröngul skorplaf, med svarta ränder och frukter, lik en landkarta : Lecidea geographica Aон. Allmän på sten.

Letlaf, allmännaste arten på sten, äfven på träd, med grå, stråligt utbredda bladflikar och rödbruna skålar: Farmelia saxatilis Acr. Allmänt känd under namn af Stenmossa, Färgmossa, Letmossa och är, liksom dess bruna förändring ( $P$. omphalodes Асв.), allmänligen använd till färgning.

Lunglaf, en stor, bredbladig, brungrön, på öfre sidan nätådrig art, allmän på gamla träd, i synnerhet Bok: Sticta pulmonacea Асв. Förr använd i medicin.

Myrlaf, en höggrön skorpa med större, köttfärgade fruktskålar: Biatora icmadophila Fr. Ingen växt upplifvar mer de ödsliga kärren än Myrlafven. Linné förvexlade den med Klubblafven, hvilken den liknar.

Nafvel-laf, lafslägtet Gyrophora Acr., med sköldlika blad, endast i midten fästa vid stenar, och med vridna frukter. Vissa arter deraf användas i Nordamerika som näringsmedel.

Anm. Wahlenberg hänför namnet Nafvellaf till Bruna Letlafven, men denne är icke till arten skild frăn den vanliga Letlafven.

Nubblaf, ett artrikt slägte, med skorplik, ofta otydlig bål och svarta, skaftade frukter: Calicium Pers.

Näfverlaf, en bredbladig, endast i kanterna uppstigande art, ofvan grå, under svart: Cetraria glauca Aor.

Olivlaf, lik Letlafven, men mörkt olivgrön: Parmelia olivacea Acr. Allmän på träd, sällsynt pâ sten.
Orseljlaf, slägtet Roccell $a$ Dro., som icke finnes i Sverige, men lemnar ett bekant färgämne.

Pricklaf, lik Olivlafren, men ljust gulgrön med svarta prickar : Parmelia conspersa Acr. Allmän på sten.

Påsklaf, slägtet Stereocaulon Aor., hvars arter äro busklika, med grenarne betäckta af små gryn, och med små rödbruna fruktknölar.

$\sim$ Qveslaf, en strålformigt utbredd laf med smala, i spetsen uppblassta bladflikar, ofvan grå, under svart: Parmelia physodes Aоr.

Renlaf, vanligen kallad Renmossa, en hvit, pipig, busklikt förgrenad art, renens förnämsta föda: Cladonia rangiferina (น.). Renlafven är grundvalen för Lapparnes hela ekonomi.

Saffranslaf, en utmärkt vacker laf, växande i fjelltrakter, med på undre sidan saffransgul bål: Solorina crocea Á́н.

Skriftláf, slägtena Opegrapha och Graphis Аон., skorplafvar, vanligen växande på träds bark, med linie-eller bokstafslika, svarta frukter.

Skägglaf, en art af slägtet Usnea Aoн., busklikt eller trådlikt nedhängande från trädstammar, med en inre, segare mergsträng: $U$. barbata $\Lambda$ он.

Sköldlaf, ett lafslägte med läderartade blad, horisontelt utbredda, med sköldlika frukter i kanterna: Peltige$r a$ WILLD.

Slånlaf, en smalbladig, på båda sidor hrit laf, nedhängande från trädens grenar, synnerligast från Slån: Evernia prunastri AcH.

Snölaf, lik Islandslafven, men gulhivit: Cetraria nivalis (L.): Sällsynt utom i fjelltrakter.

Ståltrådslaf, se Trådlaf.

Torsklaf, en art af Sköldlafvarnes slägte, mycket bredbladig, höggrön med mörkare vårtor pa öfre sidan: Peltigera aphthosa (L.). Kallas af allmogen i Upland Elfnäfver. 
Trådlaf, ett Skägglafvarne mycket liknande, trådformigt slägte, men utan den sega mergsträngen: Alectoria Acr. - En svart art kallas ståltrådslaf.

Tuschlaf, lik Nafvellafvarne, men den horisontella bålen har på öfre sidan uppstående bläddror och enkla frukter: Umbilicaria pustulata Hoғrs. Af denna laf kan tusch beredas.

Ulflaf, Ulfmossa, en citrongul, busklik laf, växande merendels på spåntäckta kyrktak, hvilket gifvit anledning till hvarjehanda skrock: $E$ vernia vulpina (L.). Se Wahlenbergs Flora Suec. s. 862.

Vinterlaf, en utmärkt, gulhvit laf, växande på klippor i koncentriska ringar, den ena utom den andra : Parmelia centrifuga (L.).

Vägglaf, se Gull-laf.

örnlaf, en skorplikt utbredd, hvitgrå laf, med tegelfärgade, skål-lika frukter: Lecanora tartarea Aor. En värderad färglaf.

Lag'eí, m., ett välbekant träd med ständigt grönskande löf: Laurus nobilis $\mathrm{L}$. Växer i södra Europa; odlas hos oss i orangerier.

Den andra (kransen) var af lager,...

Talangens pris och hjeltemodets lön. LEOPOLD 2: 291 .

Lagerkörs, f., en art af slägtet Körss, med läderartade, glänsande, icke affallande löf, införd från Orienten: Cerasus Laurócerasus Lors.

\section{Lagervide, se Vide.}

+ Lagerört, upptagen i Dalins ordbok, måste bero på något misstag, ty ett sådant namn finnes icke; det är dessutom alldeles olämpligt, emedan Tibasten, hvartill det hänföres, hvarken liknar Lager eller är någon ört.

Lakrits, m., den utpressade saften ur roten af Lakritsörten, Glycyrrhiza glabra L., tillhörande Ärtväxterna.' I äldre tider fördes namnet till vår inhemska Backsöta, af Palmberg kallad
Svensk Lakrits. I vissa landsorter anses äfven Stensötan för Lakritsrot, hvilket namn förvränges till Kariserot.

Laktuk, m., ett örtslägte tillhörande Fibleväxterna, med platta frön och hårlikt, skaftadt fröfjun: Lactuca $\mathrm{L}$. Arterna af Laktuk hafva ymnig hvit mjölksaft och äro mer eller mindre narkotiska.

Giftig Laktuk har vågrätt sittande blad, taggiga på ryggnerven: $L$. virosa I. Af dess saft beredes Lactu-irib carium.

Sallats-laktuk har bladen såsom den föregående, men utan taggar: $L$. sativa $\mathbf{1}$.

Skogs-laktuk har spjutlikt flikiga blad utan taggar; endast femblommiga blomhufvud: L. muralis Dov.

Vild Laktuk har snedvridna, nästan lodrätt stälda blad, taggiga på ryggnerven: L. Scariola L. Har ej den fräna lukt, som tillhör Giftiga Laktuken.

Lambertsnöt, f., en art af Hassel.

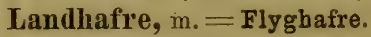

Landkartelaf, se Laf.

Landsknektar, m. pl. = Lundkovall. Kallas förnämare äfven Svenske Militärer. Om benämningen Landsknektar skrifver Linné: "Ett ganska artigt namn, emedan denna örten bär Svenska liveriet, med rocken eller bladerna, som äro högblå, och bröstet eller blommorna inunder gula”. Sk. resa 319.

+Lapphår, n., Norrbotten=Stagg. †Lapphätta, f., Dal.= Guckusko. Lappskogräs, Lappskostarr, Vesterb., åtskilliga större starrarter, som Lapparne pläga inlägga i skorna för att bibehålla värmen. Se Blåsestarr.

Lavendel, m., en sydeuropeisk ört af Sugevästernas familj, med blommor i ax, utmärkt för sin vällukt: Lavandula officinalis Cruxx. 
+Lavendelsgräs, $\mathrm{n} .=$ årbrodd. Obrukligt, onödigt namn.

+ Lavring, m., Fischerström = Sträfse.

Laxblomster, n., Medelpad = Bulleblomster.

Ledgrås, n., bättre Ledkrans, en i vatten växande ört, med bladen och små blommor i krans vid den enkla stjelkens leder: Hippuris vulgaris $\mathbf{L}$. I folkspråket förvexlas denna ört ofta med Fräken, hvilket derföre stundom benämnes Ledgräs; men oförklarligt är, huru detta namn kan af Dalin föras till Pedicularis palustris $\mathrm{L}$. [Enligt Linné, Fl. Svea. n. 551, kallas $P$. palustris i Dalsland Ledgräs. Utg. anm.]

$\div$ Leffelkrut, n., ett löjligt namn, bildadt efter Tyskans Löffelkraut, en öfversättning af Cochlearia (derefter på Srenska Skedört), hvilket jag icke skulle hafva anfört, om ej äfven Wahlenberg upptagit det. Men man har alltid varit mån om att införa rådbråkad Tyska i vårt språk.

Lefvermossor, en talrik växtfamilj, närförvandt med Löfmossorna: Hepatica Juss. De talrika nybildade slägtena ega ej Svenska namn, och sådana äro öfverflödiga, emedan dessa slägten blott af botanister komma att urskiljas. Endast några äldre slägten hafva egna Svenska benämningar, såsom Jordlunga, Jordstråla och Lefversyl.

Lefversyl, m. Så benämner Wahlenberg slägtet Anthoceros L., lätt skildt från öfriga Lefvermossor genom sina långa, syl-lika frögömmen.

$\div$ Lejonfot, m., ett ur Tyskan hemtadt namn på Daggskål, hvilket likväl aldrig vunnit burskap i Svenskan. Af alla våra med lejon bildade växtnamn förekommer ej ett enda i folkspråket; de äro införda och böra utgå, emedan vi ega bättre inhemska. $\div$ Lejongap, n., ett nyligen ur Tyska frökataloger infördt namn pà en art af slägtet Antirıhinum L. (A. majus 1.o), men olämpligt och formelt origtigt. Se Skalleblomma.

+ Lejonsvans, m., efter Tyskan och der efter Grek. Leonurus = Hjertstilla.

$\div$ Lejontand, f., äfven efter Tyskan och der efter Grek. Leontodon; men till detta slägte hör numera icke den växt, hvilken man kallat Lejontand, och namnet är således obrukbart. Jfr Höstfibla och Smörblomma.

Let ingår med betydelsen färg i en del växtnamn, såsom Byttelet, Horleta $\mathrm{m}$. fl., vanligast dock i artnamn, t. ex. Letkullor (se Kullor), Letlaf eller Letmossa (se Laf), Letmåra eller Letgräs (Galium boreale L.).

$A n m$. Flere författare skrifva lett; men i Småland, der leta brukas oftare än färga, har jag alltid hört ordet uttalas med långt $e$.

† Lettetråd, n., enligt Wahlenberg benämning på Vägtorn.

Libsticka, f., en odlad mångårig Umbellat, med gröngula blommor och egendomlig, vidrig lukt: Levisticum officinale Kосн. Libstickan säges fördrifva råttor, äfven giftiga ormar, då den planteras omkring gårdarne.

Lievarg (liens fiende), m., vexlande benämning på hårdare växter, som skada lien, t. ex. Frier, Jordvide, Stallört.

Liguster, m., en vacker buske med hvita blommor i en tät vippa och med svarta bär: Ligustrum vulgare $\mathrm{L}$. Liguster planteras allmänt till häckar i trädgårdar och växer vild i Bohuslän. Se Linnés Vestg. resa 192. - Ligusterns bär användes fordom till bläck och kallades derföre Prentebär (Engl. Print, Tysk. Dintenbeere).

Hvita ligustren försmàs, de svarta vaccinier plockas. ADTERBETH 14. 
Lilja, f., i inskränktare mening örtslägtet Lilium L., med stora prydliga blommor, lätt skilda genom en långs kalkbladen gående honungsfåra. De mest bekanta arterna äro:

Brandgul Lilja (L. bulbiferum L.), med små lökar i bladvecken, raka, brandgula, inuti sträfva kalkblad.

Hvit Lilja ( $L$. candidum L.), med raka, hvita, inuti släta kalkblad.

Kroll-lilja (L. Martagon L.), med hängande, tillbakarullade kalkblad.

En ambravind i poppelns kronor for,

I tårar liljan stod. STAGNELIUS 1:423.

Tulpaner och liljor, med öppnade kalkar,

De drucko det ljus, som från himmelen föli.

NICANDER $1: 457$.

Liljor kallas, i vidsträcktare mening, praktfulla och prydliga växter, i synnerhet af Lilje- och Narcissväxternas familjer, hvarföre lilja ingår i en mängd slägt- och artnamn. nSkåder liljorna på marken .... icke Salomo, $i$ all sin härlighet, var så klädd som en af dem». Mfatth. 6: 28,29 .

I dalen står liljan så ödmjuk, så skön.

Liljekonvalje, se Konvalje.

Liljeväxter, familjen Liliacece DEc., Etthjertbladsväxter med enkla, färgade kalkar, sex ståndare och trerummig frukt; frukten dels fröhus, dels bär.

† Limblad, n., föga passande benämning på Algslägtet Chcetophora Ac., hvilket knappt förtjenar eget namn.

Limlafvar, ordningen Collemacece $\mathrm{F}_{\mathrm{R} .}$, som skiljes från de egentliga Lafvarne genom den geléartade bålen', utan skilda lager.

† Limludd, m., strykes helt och hållet; likasom den växt, hvilken namnet skulle beteckna (svampen Thamnidium Lrsk), är rent utplånad i systemet.

+ Limmika (Eng. Lime), f., Skåne $=$ Bäck-ärenpris.

Limon, m., en art af Citronslägtet: Citrus Limonum Rrsso.
Limsvamp, m., ett af de märkvärdigaste Svampslägten, tillhörande Disksvamparne, inuti fyldt af ett segt slem: Bulgaria $\mathrm{F}_{\mathrm{R}}$.

Klotlimsvamp, liknande en kanonkula, finnes tidigt om våren i fuktiga skogsmarker: B. globosa $\mathrm{Fr}$.

Trädlimsvamp, päronformig, med tvärhuggen, platt disk, utbryter om hösten i massa ur fälda bokstammar.

Lin, n., örtslägtet Linum I., egentligen dess allmänt odlade art $L$. usitatissimum L. Detta namn har numera $i$ riksspråket utträngt det äldre Hör. Linblomma. АтTERBom 1: 54 . $\mathrm{nS}$ Bedæ dag lin, får du tågan fin». Ordspr. Linplantan sjelf spinner finaste tråd.

Tre alnar var linet och trenne hvart gräs.

\section{Linbinda, se Binda.}

DAHLGREN 1: 375 .

Lind, f., vårt vackraste och sendst blommande trädslägte, med hjertlika blad och välluktande blammor på skaft, som bär ett tunglikt skärmblad: $T i$ lia L. - Af Lind har Linné erbållit sitt namn. - nLind är det angenämsta trä i ängar, dem hon göder med sina blad eller löf och vederqvecker med sin skug. gan. Linnés Vestg. resa 67.

Djupt i kämpens aska linden

Slår sin rot och susar uti vinden. TEGNER 3: 43.

En ångande vällukt sig sprider från linden.

DAHLGREN 1: 419.

Allé-lind, med större, glatta blad och hårda, ludna frukter: T. vulgaris HAYNE. Är den i alléer oftast planterade och benämnes äfven Holländsk Lind.

Holländsk Lind, med stora, på undre sidan ludna. blad: $T$. grandifolia Енгн.

Skogslind, med smärre, glatta blad och tunna, sneda, glatta frukter: $T$. parvifolia Енвн. Den allmännaste arten.

Lindodra, se Dodra.

Lingonris, n., en ständigt grönskande halfbuske, tillhörande Ljung- 
växterna, med röda, i klase sittande bär: Vaccinium Vitis idcea L. Bären kallas Lingon, äfven Lingbär.

Hvad lyser här så rödt?

Lingon! Hela fältet fullt beströdt. FRANZEN 1: 369 .

Och med sin grönskande prakt kröp gladt $i$ lockarnes skymning

Lingonriset omkring; det ïr myrtenkransen i Norden.

† Lingräs, se Linört. TEGNER 2: 94.

Linnea, Linnésört, f., en liten, refvig buske med upprätta, i spetsen klynnedelade stänglar och klocklika, hängande, rödletta kronor: Linncea borealis L. Jfr Jordkrona. - Sveriges barrskogar äro Linneans rätta fädernesland.

Här i sitt rätta hem hur skön och välluktsrik!

Och ingen $i$ behag Linnea öfverträffar. FRANZEN 4: 61 .

Linnés Fårgräs = Fårsvingel. Linnés Höfrö = Fodersmäre.

\section{Linrepe, se Repe.}

Lins, m., ett från Vickorna knappt skildt slägte genom mycket små blommor, kronan endast af fodrets längd: Ervum L. Utom den odlade, Äkta Linsen ( $E$. Lens L.), hafva vi tvenne vilda arter: den ludna Duflinsen $(E$. hirsutum $\mathrm{L}$.) och den glatta Sparflinsen (E. tetraspermum L.). - Då linsen $\mathrm{mog}$ nat, dukas sparfvarnes bord".

Lin-snarrefva, se Snarrefva.

$\div$ Linört (Lingräs) = Flugsporreblomma.

Ljung (i äldre språket Ling), äfven Lyng, Liöng, m. Småbuskar med qvarsittande, barrlika blad. 1) Slägtet Erica L., med fröhusets skiljeväggar vidhäftade fröfästet, är högst artrikt, synnerligast $p a ̊$ Cap, hvarifrån flera arter hos oss odlas som prydnadsväxter; blott en är inhemsk, nemligen Klockljungen (E.Tetralix L.).'2) Slägtet Calluna SALIsBo, med fröhusets skiljeväggar vidhäftade fröskalens kanter; deraf finnes blott en art: Allmänna Ljungen (C. vulgaris $\mathrm{S}_{\triangle \mathrm{AI} I \mathrm{~B}_{\mathrm{*}}}$ ), hvilken utgör våra stora ljunghedar, mest i de vestra landskapen. Mycket grof Ljung får namn af Häst- eller Hors- eller Rossljung (äfven Rossling).

Anm. Skulle man önska egna namn för ofvannämnda slägten, måste Calluna bibehålla namnet Ljung, och för Erica antagas Eriker, såsom dess arter kallas i trädgårdsspråket.

Ljungpimnar, m. pl., benämning på växter med hårda, sega rötter, som hindra plogen (t. ex. Blåhallon, Fodersmäre, stallört), icke på någon bestämd växt. Se_Retzius 2: 471 . Jfr Rast.

† Ljungsilke, n. Hvarken växten (Cuscuta Epithymum L.) eller namnet förekommer i Sverige.

† Ljungsnöre, n., Hall. = Movippa. Se Bot. utfl. 3: 238.

+ Ljusbrand, m., ett äldre namn på Kungsljus.

\section{Ljussläckaremossa, se Mossa.}

Loka, stamordet i flere Umbellaters namn, t. ex. Hundloka. Jfr Eng. Hemlock.

+ Lomme, Lommegräs, Lummegräs, $\mathrm{n} .=$ Taskört. Jfr Linnés Sk. resa 211. Som Capsella förr förenades med Thlaspi, har namnet blifvit $\mathrm{i}$ systematiska arbeten öfverfördt på den senare.

Lonke, n., en vattenväxt med motsatta blad, utan både blomfoder och blomkrona: Callitriche L. $\ddot{\mathrm{Ar}}$ stamordet till Lunk och Lönke. Må ej förvexlas med Lånke af Lat. Lonchitis.

Lonkesèrf, m., ett med Lonke lätt förvexladt örtslägte, men som har både blomfoder och blomkrona: Elatine L.

† Loppgxiis, n. 1) i Österg. en art af slägtet Lummer: Lycopodium Selago L. ; 2) en art af slägtet Slideknä: Polygonum Hydropiper L.; 3) Lopp- 
frögräs, en utländsk art af slägtet Groblad: Plantago Psyllium L.

† Loppris, n., Skåne $=$ Kråkris.

Loppört, f., ett med Alanten förvandt örtslägte, med klynnedelad stjelk, klibbiga blomhålkar och mycket små strålblommor: Pulicaria vulgaris GæRTN. Loppörten har en ştark kryddlukt.

Losme, m., Gotl. = Dårrepe. (Ordet är en flexion af Losta.)

Losta (Lösta, Lyxa, Löxa), f., ett grässlägte med vippa, mångblommiga småax med borst, infäst nedom agnskalens spets: Bromus I. - Råglosta (B. secalinus $\mathrm{u}$.) är ett svi̊rt ogräs bland vintersäd. Öfriga arter ådraga sig icke allmännare uppmärksamhet.

Lotusblomma, f., en i Egyptiska och Indiska mytologien framstaende art af Neckrosslägtet: Nymphcea Lotus $\mathrm{L}$.

Lotusbuske, m., en i norra Afrika växande taggig buske med gula bär: Zizyphus Lotus L Lass. Lotusbusken har gifvit namn at Herodots Lotophager.

$A n m$. De båda föregående namnen tillhöra väl ej Svenska språket, men hafva en mytologisk och historisk märkvärdighet och förtjena derföre att $\mathrm{i}$ ett bihang upptagas.

Lucern eller Luzern, m., en odlad art af slägtet Smäre, med blå blommor: Medicagó sativa L. Se Blåsmäre.

Den bladiga Lucern, de plöjda ängars heder.

† Luck, Luckört, se Låck.

† Luddborste, ḿ. Då den växt, som dermed skulle betecknas (svampen Coremium Lrsx), nu är rent utstruken i systemet, måste namnet göra sällskap.

+ Luddlönn, f., en art Amerikansk Lönn (Acer dasycarpum Енвн.), som ej förtjenar att upptagas i en Svensk ordbok.

Luddtåtel, se Tåtel.
† Luddört, f., ett mig obekant namn på Musörten.

Luftblomma, f., kan antagas som gemensamt namn på de i tropiska länderna (synnerligen Amerika) talrika parasitiska Nosseväxterna (Orchideer), hvilka nu ofta odlas i Europeiska växthus. Dalin hänför namnet till Aërides odorata Lour.

† Luktgräs, n., ett obestämdt namn, tillagdt allehanda starkt luktande växter, t. ex. Mjödört, Myska, Hässlebrodd och Vårbrodd.

† Lukthirs, m., ett föråldradt och obrukligt namn.

† Luktmolla, f., ett ej opassande namn på Chenopodium ambrosioides L. ; men jag betviflar att det bör upptagas, då växten ej är Svensk eller eljest utmärkt.

$\div$ Lukt-tuppor, f. pl.= Kamillblomster.

Lukt-törne, se Törne.

Luktviol, se Viol.

+ Luktärt, f. (rättare Luktvial), en prydlig Ärtväxt, som stundom odlas, men är ej inhemsk: Lathyrus odoratus $\mathrm{L}$.

† Lumkräkling, Lummerlyng (Finmarken), m., en art af slägtet Rosling, med i fyra rader öfver hvarandra liggande blad: Andromeda tetragona $\mathrm{L}$.

Lummer, m., ett egendomligt slägte bland Groddtrådsväxterna, närmast beslägtadt med Fräken, men till örtståndet mera likt Mossor, med ax i grenarnes topp: Lycopodium $\mathrm{L}$. Dess af allmänheten urskilda arter (utom Jemna, som har sjelfständigt namn) äro:

Luslummer, med upprätta, tudelade, upp till toppen bladiga grenar: L. Selago $\mathrm{L}$.

Mattlummer, med nedliggande refvor, skaftade ax : L. clavatum L. Frömjölet kallas Lumrik. 
Reflummer, med nedliggande refvor, oskaftade ax: $L$. annotinum $\mathbf{L}$.

(Smålummer upptages särskildt.)

Anm. Namnet Lummer har alldeles origtigt blifvit öfverfördat till Sqvattram.

†Lummerlyng, se Lumkräkling. Lundgröe, se Gröe.

Lundkovall, se Kovall.

Lundslok, se Slokgräs.

Lunglaf, Lungmossa, se Laf.

Lungrot, f., enligt Linné en art af slägtet Mell, med triangelformigt spjutlika blad och talrika gyttrade blommor: Chenopodium Bonus Henricus L. Namnet brukligt i Upland $\mathrm{m}$. fl. st.

Lungört, f. 1) i skriftspråket ett slägte af Skrufblomstriges familj, blommande tidigt om våren: Pulmonaria L.; 2) , i folkspråket namn på Tallörten (Upland) och Kungsljuset, Verbascum Thapsus (Kalmar län m. fl. st.; så äfven i Norge och England).

Lunk, se Källelunk.

Lupin, m., ett örtslägte af Ärtväxternas familj, af hvilket aitskilliga arter odlas som prydnadsväxter och en som kaffe-surrogat: Lupinus. L.

Eärfva lupiners dånande skog och bräckliga stänglar.

Lusfloka, f. (Lushatt, Lusört), kallas i Vermland och Norrland en art af slägtet Stormhatt, med håriga blad och smutsblå blommor: Aconitum Lycoctonum L. A. septentrionale KorLL.

$\div$ Lusgrås, n., ett högst obestämdt namn: 1) slägtet Frier, enligt Linnés Vestg. resa 4, efter Lat. Pedicularis, men ej brukligt i folkspråket; 2) Lusfloka; 3) Munkfnat; 4) Luslummer.

Luslummer, se Lummer.

Luzern, se Blåsmäre.

Lyckoblad, se Fyrväpling.

$\div$ Lysblomster, n., enligt Dalins ordbok = Videörten, Lysimachia vulgaris L. Ett mig obekant namn.

\section{Lyxa, se Losta.}

Låck, Låcka, f., i de vestra landskapen den vanligaste benämningen på Sipporna, såsom Hvitlåckor, Blălåckor för Hvitsippor, Blåsippor. (Hos Franckenius och Bromelius förekommer Hvitlock.) I Halland, der namnet uttalas Låga, hänföres det äfven till Caltha L., som kallas Gulalåga.

Långfredagsbjörk = Dvergbjörk (se Björk). Enligt legenden hudflängdes Kristus med qvistar af denna björkart, hvarföre den blef förbannad och dömd att krypa på marken; men Hängbjörken, som stod nära, sörjde så, att grenarne slokade ned, hrilket man ser ä̀ $\mathrm{i}$ dag.

\section{Långpeppar, se Peppar.}

Långrofra, se Rofva.

†Lånke, m., en art af slägtet Ormbunke = Bergspring. Namnet, bildadt efter Lat. Lonchitis, är ej antaget i folkspråket.

Låsbräken (Låsgräs), n., ett slägte bland Bräkenväxterna, med ett deladt blad och grenigt ax $\mathrm{i}$ toppen: Botrychium Sw.

† Läblad, n., Dal. = Neckblad, emedan vattnet innanför dessa blad blir lugnt. Kallas äfven för sin läderartade beskaffenhet Lärblad (läderblad).

Läkeblad, $\mathrm{n}_{\text {., Låkeblacka, } \mathrm{f} .=}=\mathrm{V}$ Groblad.

Läketunga, f,, ett slägte bland Bräkenvärterna, förvandt med Låsbräken, men med ett odeladt blad och enkelt ax: Ophioglossum L. - nOphioglossum kallades Läketunga, af hvilken här på orten gjordes en läkande salfran. Linnés Gotl. resa 175.

Läkeört, f., nomen appellativum för medicinalvärster och icke någon bestämd växt (såsom Liljeblad och Hartman uppgifva i afseende på Sanicula europeca L.).

†Länsmansstöflar, m. pl., Rosl., Blek. = Skogsviol och Hundviol. 
Lärftsblomma, f., Smål., Blek. = Knylbräcka.

Lärkblomster, n., Upl. = Majh

Lärkträd, n., ett barrträd, likt Tall, men med spädare, knippvis sittande, årligen affallande barr: Larix europaea Dzc.

Löfbinda, f., se Binda. Genom förrexling föres detta namn äfven till Åkervinda. Se Linnés Sk. resa 392.

Löfkoja (Levkoja), f., en bekant, vanligen i fönster odlad art af slägtet Matthiola, med fioletta blommor: $M$. incana $\mathrm{R}$. Br.

\section{Löfmossor, se Bladmossor.}

Löfträd, n., träd med platta, hos oss årligen affallande löf, till skilnad från Barrträd, som hafva syl-lika, vanligen qvarsittande barr. - nDet vore ej ringa prydnad för riket, om allmogen öfverallt i Sverige kunde förmås att vid sina gârdar plantera löfträn, helst af de 4 högstammade slagen: Alm, Lind, Lönn eller Ask, ... ty en gård utan trä är som ett skalligt hufvud utan peruquen. Linnés Vestg. resa 7 .

Lök, m. (Isl. laukr), ett allmänt bekant och från äldsta tider odladt örtslägte (redan i 4 Mos. 11: 5 omtalas Purlök, Rödlök, Hvitlök), tillhörande Liljeväxterna, skildt från öfriga genom sin egendomliga löklukt: Allium L. De mest bekanta arterna deraf (utom Ramslöken, sóm särskildt upptages) äro:

Chalottenlök (A. ascalonicum L.), med bar stängel, trinda blad och treuddiga ståndare. Odlas, men blommar ej hos oss.

Gräslök (A. Schoenoprasum L.), lik den föregående, men med enkla ståndare. Både vild. (kallas på Öland Alvarlök; se Linnés Öl. resa 53) och odlad.

Hvitlök (A. sativum L.), med bladig, rund stjelk, treuddiga ståndare, sammansatt lök. Odlas.
Kejpe- eller Skogslök ( $A$. Scorodoprasum L.), lik den föregående, men med tve-eggade bladslidor och enkel lök. Vild.

Piplök (A. fistulosum $\mathrm{I}$.), lik Rödlöken, men stjelken jemntjock, bladen uppblåsta, pipiga. Odlas.

Purjolök (A.Porrum L.), lik Kejpe, men blomhufvudet utan lökar. Odlas.

Rödlök (A. Cepa L.), med bar, nedtill uppblåst stängel, trinda blad. Odlas.

Sandlök (A. arenarium L.), med bladig, rund, lökbärande stjelk, treuddiga ståndare. Vild. Ar ett vid Skanör och flerstädes högst förderfligt åkerogräs till följd af smålökarne i blomflocken, hvilka blandas med säden.

Ängslök (A. oleraceum L.), lik den föregående, men med enkla ståndare. Vild. Kallas äfven Hundlök.

Lök ingår äfven i namnet på värter, som hafva a) löklukt, t. ex. Hvitlöksört, Löksuga; b) lökformigt gyttrade blad, t. ex. Huslök, Taklök; c) lökformiga blomknoppar, t. ex. Kabbelök; d) lökformiga frukter, t. ex. Lökäpplen,

\section{Lökpäron.}

Löksuga, f., en ört af slägtet Teucrium L., tillhörande Sugeväxterna, men blommorna sakna öfverläpp, och vår art (liksom en Norsk) utmärker sig genom löklukt: T. Scordium L. Flera utländska arter af detta slägte hafva sjelfständiga namn. Gamander kan ej hänföras till vår art.

Lökväxter benämnas alla Liljeväxter som hafva lökar, men ej höra till Lökslägtet, stundom äfven andra. I dessas slägtnamn ingår vanligen lök, t. ex. Stjernlök, Vårlök m. fl.

Lönke, m., en i vatten nedsänkt mossa, vida afvikande från öfriga Mossor: Fontinalis L. (F. antipyretica L.)

Lößn, f., ett allmänt kändt slägte bland Löfträden, utmärkt af flikiga 
blad, samtidigt med löfven utslående gulgröna blommor med åtta ståndare: Acer L. Lönnarne hafva vårtiden en sockersöt saft, i synnerhet den Nordamerikanska Sockerlönnen (A. saccharinum $\mathrm{L}_{\text {.) }}$, af hvars saft socker beredes. De hos oss allmännare kända arterna äro:

Svensk Lönn (A.platanoides $\mathbf{x}$.), med spetsflikiga blad och uppirätta blomvippor. Vild.
Tysk Lönn (A. Pseudoplatanus L.), med trubbflikiga blad och hängande blomklasar. Planterad.

(Nafverlönn upṕtages särskildt.)

Långs öfver dörren ett bårkläde hängde Utaf de gulnade lönnarnas blad. DAHLGREN 2: 264 .

†Löpegräs, n., Öland = Gulmåra. Användes till mjölks ystning.

†Lössegräs, n.,Boh.=Kattmynta.

Lösta, Löxa, se Losta.
Madd, m., ett med Måra närförvandt örtslägte, med blekblå blommor, omgifna af allmänt hylle: Sherardia I. - Åkermadd (S. arvensis L.) kallas af Wahlenberg Blåmadra.

Madra, f., örtslägtet Asperula L., närbeslägtadt med Måra, men skildt genom blommornas pip. Vi ega deraf två inhemska arter:

Färgmadra (A. tinctoria $\mathrm{L}$.$) , med$ i krans sittande smala, jemnbreda blad. Se Linnés Gotl. resa 238.

Myskemadra (A. odorata L.), med atta i krans sittande lancettlika blad; synnerligast utmärkt genom sin vällukt. Kallas vanligen Myska.

Anm. Namnet Madra, ännu för detta slägte bibehållet på Gotland och Island, tillades fordom alla Mråravîxter.

$\div$ Madun, n., Smål. = Ängdun.

Mahogny, n., ett vackert och hårdt träslag, som erhålles af Swietenic Mahagony $\mathrm{L}$. från Sydamerika.

Majblomster, n., en obestämd benämning på flera vårblommor, olika i olika landskap, t. ex. Konvaljen, Majhvifvan (Österg.), Mjödörten (Dal.), flera arter af Solöga (Vestm.) o.s. v.

Majbräken, n., en Bräken-art, som i systematiska arbeten föres till slägtet
Bergspring, men är till utseende och växtsätt så lik Ormbunkeslägtet, att den måste behålla sitt sjelfständiga namn: Asplenium Filix femina (L.).

† Majgräs, $\mathrm{n} .=$ Myskegräs, Vårbrodd $\mathrm{m}$. $\mathrm{fl}$.

\section{Majhvifva, se Hvifva.}

Majlilja, f., äldre, ännu i vissa orter brukligt namn på Konvalje.

+ Majnyckel $=$ Gulhvifva, enligt Dalin. Mig obekant namn.

IIajs, m., ett särdeles bördigt sädésslag, med skilda han- och honax: Zea Mays L. Majsen tillhör ursprungligen Amerika och odlades der före Europeernas ankomst.

Den höga majs, som axets yta fyller Med korn i perlors form, dem mogna- den förgyller. OXENSTJERNA 2: 130 .

† Makrasse, m., Smål, = Ängkrasse.

† Malva, f., Latinska namnet på Kattost, hvilket ej kan tillhöra Svenska sprâket.

Malört, f., en för sin beska smak allmänt bekant art af slägtet Gråbo: Artemisia Absinthium L. - Malörten är efter allmogens uppfattning en symbol af ångern. 
Honing du bjuder min mun, och malört ger du mitt hjerta. BÖTTIGER 2: 155.

Manceniljträd, n., ett Vestindiskt träd af Törelfamiljen: Hippomane Mancinella $\mathrm{L}$. Innehåller ett bland de häftigaste slags gift i växtriket.

Mandel, m., frukten af Mandelträdet, tillhörande Stenfruktträden, inhemskt i Orienten och södra Europa: Amygdalus communis $\mathbf{L}$.

Gif ock med omsorg akt när mandelträdet $i$ skogen

Står af sin blomning höljdt med sänkta doftande grenar.

ADLERBETH 59.

Dvergmandel, en lågväxt buske med röda blommor, hvilken tål vårt klimat och odlas som prydnadsväxt: A. nana $\mathrm{L}$.

\section{Mandelpil, se Pil.}

+Mandelpotates. Dylika till trädgårdsspråket hörande benämningar anser jag icke böra upptagas.

+ Mandelsäf, se Jordmandel. Namnet utgår alldeles; den ifrågavarande växten tillhör ej Säfslägtet.

Mangroveskogar, m. pl., uppkomma på de af tidvattnet öfversköljda hafsstränderna i heta zonen genom träd, tillhörande Rhizophorece R. BR., hvilka från grenarne nedskjuta rotslående luftrötter och sålunda bilda ogenomträngliga skogar.

Maniok, m., ett stärkelseartadt mjöl, som erhålles af roten på Manihot utilissima Ронг. Kallas ock Tapioka.

Mannablod, äfven Danskablod, n. = Sommarhyll. "Mannablodet stod nu i full blomma och uppfylde hela trakten med sin lukt», Linnés Öl. resa 304. Om denna ört den "sagan går, att den på ingen annan ort $i$ verlden skall finnas mer än endast vid Kalmare slott, derest hon skolat uppsprungit af Svenskars och Danskars blodn. Ders. 35. - Alldeles samma sägen finnes i England, der växten kallas Danesblood, vid en by nära Chippenham, hvarest fordom ett fältslag stått med Danskarne.
Mannagrås, n. (Mannagröe), ett vattengräs med långsträckta, mångblommiga, borstlösa småax och på vattnet flytande blad: Glyceria fluitans R. Br. Af dess frön erhållas Mannagryn. "Mannagryn, samlade här i landet (Skåne), sågos... så vackra och klara som någonsin utländskan. Linnés Sk. resa 263.

Anm. Kallades förr i. systematiskt interesse Mannasvingel, men detta namn är origtigt och numera obrukligt.

Mannaträd, n., en i södra Europa växande art af slägtet Ask, Fraxinus Ornus L., hvilken eger fullständiga blommor med blomfoder och blomkrona, som båda saknas på vår Ask. Af dess utsvettande, stelnade saft erhålles den i handel förekommande Manna.

Manshlod, n., ett gammalt och ännu brukligt namn på Johannesknopp (Hypericum quadrangulum och perforatum L.). De krossade blomknopparne lemna en blodröd fläck.

Manschetter, m. pl., en i trädgårdsspråket vanlig benämning på Spikklubban.

Manskraft, f., ett mycket afvikande slägte bland Umbellaterna, med styfva, läderartade, taggiga blad och blommorna i ett hufvud: Eryngium maritimum L. Manskraften växer på sandiga hafsstränder.

Mar- ingår i flera arters eller afarters namn, betecknande dels kärr, t. ex. Marbjörk, Martall, dels låga, sandiga hafsstränder, t. ex. Marfiol (se nedan), Margräs eller Marhalm (= Sandrör), Marvide (Salix angustifotia $\mathrm{Fr}_{\mathrm{r} .}$ ).

\section{+ Marchantsmossa $=$ Jordlunga.} Utgår alldeles.

Marfiol, f., en ört af Korsblomstriges familj, med gredelina blommor och kantiga, icke uppspringande skidor: Cakile maritima Scop. Kallas äfven vild Lackfiol. 
Mariæ, se Jungfru Mariæ.

Marientistel = Sempertin.

Marksmultron, se Smultron.

Mar-risp, m., ett på hafsstränder växande örtslägte med breda rotblad och bladlös, mycket risgrenig stängel: Statice $\mathbf{l}$.

\section{Marsviol, se Viol.}

Maskfrö, n., maskdödande medel, som erhålles af flere Boväxters frön, företrädesvis af en art Gråbo, Artemisia Santonica I., äfven af Renfana.

Maskmjöl, $\mathrm{n} .=$ Lumrik (se Mattlummer).

$\div$ Maskros, f。 $=$ Smörblomma. Ett nyare namn, som likväl ingaitt hvarken i folkspråket eller skriftspråket. Nagon rimlig hänsyftning deri kan jag icke finna.

+ Maskrot, f., benämnes i Dalins ordbok roten af Spigelia Anthelmia L. Örten hvarken odlas eller växer vild hos oss och är för Svenska allmänheten obekant.

† Maskull, f., svampslägtet Arcyria Hris; egentligen ludden i dess och slägtet Trichice HaLr hyllen. Utgår.

Mastix, m., ett ljusgult harts, som erhålles af Pistacia Lentiscus L. från Orienten. Mastix användes till rökelse. Se Hesek. 27: 17.

Masur- tillsättes växtnamn för att utmärka hårdare träslag, t. ex. Masurbjörk, Masurlönn.

Matledsqvistar, m. pl. Namnet tillkommer rättast Besksöta, men öfverföres ofta $i$ de vestra landskapen på Svensk Caprifolium.

Matolja, f., pressas icke blott af Oliv, utan äfven af Vallmo.

Mat-rhabarber, se Rhabarber.

$\div$ Matsvamp $=$ ätlig svamp. Namnet är obrukligt och alltför obestämdt att föras till någon viss art.

\section{Mattgräs, $n .=$ Mattlummer.}

\section{Mattlummer, se Lummer.}

Mattram, m., bildadt af Lat. $M a$ tricaria (M. Parthenium L.), men vanligen fördt till Battram (se der). Namnet, ofta förekommande i äldre skrifter, är nu utgånget.

+ Mauritia-palm, obekant för Svenskar.

Meccabalsam, m., ett harts, innehållande eterisk olja af ett med Terebinten beslägtadt träd i Arabien : $B a l$ samodendron gileadense KunTI (Amyris gileadensis L.).

† Meja, f. (Hvitmeja), Skåne, enligt Linné = Hvitsippa. Utdödt namn.

Mejram, m., en allmänt odlad kryddväxt, tillhörande slägtet Koning: Origanum Majorana L.

+ Melblomster, n. = Majhvifva.

Melilot, m. = Amur. Det förra namnet är nu vanligen brukligt; bekant är t. ex. Melilotplåster.

Mell, Mellre, f., ett med Molla närförvandt örtslägte, men har alla blommor likformiga och tvåkönade: Chenopodium L. Mellens blad äro vanligen mjöliga, och namnet härledes af mel, mjöl. (Äfven Mjölkroten hör, enligt Linné, till detta slägte.) De bekantare arterna äro:

Bymell, med triangulära blad: $C h$. urbicum $\mathrm{L}$.

Rödmell, med romboidiska, glänsande blad: Ch. rubrum L. Föres i systematiska verk till slägtet Sminkbär.

Stinkmell, med äggrunda, helbräddade blad: Ch. Vulvariu L.

Svinmell, med olikformiga, vågiga blad, hvitmjöliga blomklasar: Ch. viride L., äfven Atriplex patula $\mathrm{L}$.

Melon, m., en odlad, välkänd art af Gurkslägtet: Cucumis Melo I. 
Re'n är den varma bänk utaf meloner klädd,

Som rundas under glas vid jordens làga bädd,

Der sommarn deras skal med blommans likhet målar

Och gjuter svalkans saft $i$ deras gula skålar.

OXENSTJERNA 2: 54.

Menniskolif, n., se Purpurvinda.

† Menniskovän, m., ett gammalt, nu obrukligt namn på Snärjegräs, emedan denna växt hänger sig fast vid kläderna. Jfr Snarmåra.

Mespel (mindre rigtigt Mispel), $\mathrm{m}$. 1) Egentligen ett buskslägte bland Kärnfruktträden, med större, upptill skålformiga frukter: Mespilus germanica L. Denna är mera sällan odlad. 2) Vanligast, men oegentligt gifves namnet Mespel åt Amelanchier canadensis MED. (Mespilus canadensis L.), en buske, äfven tillhörande Kärnfruktträden, med små svarta, ätliga bär. 3) Äfvenledes 0xbärsbusken (Cotoneaster vulgaris Lisdu.) har i systematiska arbeten blifvit kallad Mespel, men då den numera ej räknas till Mespelslägtet, bör sådant namn på denna buske försvinna.

$\div$ Midsommarsblomster, n. I anseende till den stora utsträckning och följaktligen de olika klimat Sverige eger, är det klart, att detta namn användes olika i flera landskap. Sålunda hänföres det i Skåne till Hästfibla, i Småland till Nosserot, i Vermland till Knylbräcka, i Medelpad till Ängsnäfva (i Jemtland kallad Jansmesseblomster), i Vesterbotten till Allmänt Solöga. Vill man derföre upptaga namnet $i$ en Svensk ordbok, bör det endast tydas med örter, som blomstra vid midsommarstiden.

$\div$ Millefolium, n., rent Latin, men brukas ofta i talspråket för Röllika.

Minnesviol, f., Atterbom $=$ Styfmorsviol.
Mire (Tysk. Miere), m., Visby = vàt-arv.

\section{Mispel, se Mespel.}

Missne, n. (i Dalarne f.), äfven Måss, en i kärr växande ört med tjock rotstock, hjertlika blad, tjock blomkolf, omgifven af ett på inre sidan hvitt hölster, och med röda, tätt sittande bär: Calla palustris L. Af Missnets tjocka rot beredes i Norrland bröd i missväxtår.

Mistel, m., en på träd växande, ständigt grönskande buske med ledade stjelkar och hvita, enfröiga bär: Viscum album -L. Misteln (Isl. mistilteinn) är välbekant i nordiska mytologien. Af Mistelns bär kokas fogellim.

†. Ijella, Holtemjella, f., Dalsl. = Ängskovall.

Mjeltbräken (föråldradt: Mjeltgräs), n., en hos oss sällsynt Bräkenväxt (förekommande på Gotland), med odelade, vid basen hjertlika blad med linieformiga fruktplättar på undre sidan: Scolopendrium officinarum Sw.

Mjödört, f., en på fuktiga ställen allmän, parbladig ört, tillhörande Brumväxterna, med stor blomruska i toppen, hvita, starkt honungsluktande blommor: Spircea Ulmaria L. Har talrika benämningar i mellersta och norra Sverige, men det i Göta rike (äfven Danmark och England) allmänt brukliga namnet Mjödört är det mest karakteristiska.

MIjöldagg, f., en på lefvande växter parasitisk, högst skadlig svamp, bildande mjöl-lika fläckar med små gulbruna knappar: Erysiphe HEDW. FIL. Den mycket omtalade Drufsjukan i södra Europa (Ö̈dium Tuckeri Berk.) är en outbildad form af Mjöldaggen.

Mjöldryga, f. = Brandkorn.

†Mjölgräs, n. = Svinmell. Obrukligt namn. 
Mjölkblomster, Medelp.. Mjölkros, Upl., Trimjölksgräs, Angerm., ett mycket obestämdt namn i folkspråket. Torde rigtigast hänföras till Kabbelök, enligt namnets användande i nämnda provinser, men tillägges temligen allmänt Smörblomman, och i Dalsland Leontodon autumnalis $\mathrm{t}$.

Mjölke, m. (Mjölkgräs Dal., Imjölke Nerike, Illermjölke Hels., Råmjölksgräs Österg., Aldermjölk Franckenius, att förtiga de rådbråkade uttalen i Dalarne), ett ständigt vexlande namn på.Kropp, synes vara det förherskande i mellersta Syerige, liksom Almocke i norra och Allonmärke i södra, och dessa så skilda benämningar gå genom medelformen öfver i hvarandra.

Mjölkfibla, f., vanligen, men mindre lämpligt Mjölktistel, m., ett örtslägte af Fibleväxterna, med ymnig hvit mjölksaft, i kanten småtaggiga blad: Sonchus L.

Allmän Mjölkfibla (S. oleraceus L.), ett besvärligt, ettårigt ogräs i trädgårdar.

Fet Mjölkfibla, Åker-mjölkfibla (S. arvensis $\mathrm{L}$.), ett större, mångårigt, svårt åkerogräs.

† Mjölkgubbar, m. pl., Dalsland $=$ Blàsuga.

... $\div$ Mjölkpungar, m. pl., Upl. = Bråki-kiöfver.

Mjölkros, f., se Mjölkblomster.

Mjölkrot, f., Rosl., en mångårig art af slägtet Mell: Chenopodium Bonus Henricus L. - Af Wahlenberg föres namnet till Mossrot.

Mjölkskifling, Mjölksopp, m., ett slägte bland Skifsvamparne, hvars arter brutna utsippra en mjölksaft: Lactarius PEns. Hit höra Brötling, Pepparling, Riska, som äro särskildt upptagna.

† Mjölktistel, se Mjölkfibla.
Mjölkvial, m., Medelp.= Ängskovall.

Mjölk-ysta, f. = Guimåra.

† Mjölköka, f., öfversättning af Polygala (se Jungfrulin), ett namn som förekommer i böcker, men för öfrigt ej brukas.

Mjölkört, f., en gemensam benämning på arterna af slägtet Törel, specielt på Reforms-töreln (Euphorbia Helioscopia L.). I sammansättningar bortfaller ört, t.ex. Räfmjölk (E.Peplus L.) och Vargmjölk (Kärrtörel, $E_{\text {. }} p a$ lustris L.), af Bromelius kallad Djefvulsmjölk. - Enligt Linné (Sk. resa 240) öfverföres namnet Mjölkört äfren till Höstfiblan.

Mjöl-laf, utgår, se Laf.

Mjölonris, n., en liten, nedliggande, ständigt grönskande buske af Ljungfamiljen, med ofvan blomkronan sittande bär, hvarigenom denna buske skiljes från Lingonriset: Arctostaphylos Uva ursi (L.). Frukten kallas M jö- $^{-}$ lon, Mjölbär. - Jfr Fjellbär.

Du landets fria bygd,

Som... plundrar tufvans skatt och stryker mjölonlöfven. DAHLGREX 1: 31 .

Mjölöka, f. = Brandkorn.

Mobjälla, f, Vesterg.= Linnésört.

Molla, f., ett artrikt örtslägte, närförrandt med Mell, men har trå slags blommor, jemte tvåkönade äfren olikformade honblommor: Atriplex L. De mest bekanta arterna äro:

Svinmolla, som är ett allmänt ogräs på odlad jord: A. patula $\mathrm{L}$.

Trädgằrdsmolla, hvilken allmänt odlas och användes som spenat: $A$. hortensis $\mathrm{L}$.

Mollaväxter, naturliga familjen Chenopodiacece Dussorr., Tvåhjertbladsväxter med kronbladslösa, merendels femtaliga blommor och med hinnfrukt. Blommorna äro små, gröna. Hit höra Molla, Mell, Sodaört, Saltört, Glasört $\mathrm{m}$. fl. 
Molter, f. pl.,-i de vestra landskapen, Multer i Dalarne, $=$ Hjortron.

Monke, m., en ettårig växt, allmän i södra Srerige, med blå blommor i ett rundt hufvud på korta skaft: Jasione montana L. Ursprungliga namnet är Munkhatt, men nu är Monke allmänt antaget.

Mor (skog) ingår i några växtnamn, såsom Morhattar, Morkulla, Mortåg.

Morell, m., en afart af Körsbär.

Morgonstjerua, se Stjernlök.

$\div$ Morhattar, m.pl., Dal.=Skogsnäfva.

Mo-ris, n., Ångerm. = Ljung.

Morkulla, f., Dal. = Dufkulla.

Morrot (äfven Morot), f., en allmänt odlad växt af. Umbellaternas familj, med fintaggiga frukter: Daucus Carota L. Den odlade Morroten har en tapplik, köttig, ätlig rot; den vilda deremot en smal, träaktig. Se Barkenrot.

Mortåg, äfven Myrtåg, m., Norrl., en art af Ormrot, Lilla Ormroten (Franckenius). Se Ormrot.

Mosisroser, f. pl., Rosl., en art af Blåklocka, Campanula glomerata $\mathrm{L}$.

Mossa, f., en talrik klass af Groddtrådsväxterna (Musci L.), med tydligt utbildade vegetationsorganer och sporkapslar, men utan spiralkärl. Den fördelas i Löf- och-Lefvermossor. - nMrossor kallas (inom växtriket) slafvarne, som tjena växterna, dem de täcka för vinterkölden, skydda för solhettan, fria för rutnelsen, men vika för alla andra». LINNÉ Delic. nat. 14.

Ett hyende, prydt af den nyfödda sippan Och virkadt af mossornas sammet, der låg.

LING 1: 16.

Anm. Mossa har från äldsta tider varit en gemensam benämning på alla Groddtrådsväxter, utom Bräkenväxterna och Svamparne. Numera afsöndras allmänt Lafvar och Alger, som olämpligt äfven kallats mossor. De talrika Lafarter, hvil$\mathrm{ka}$ af Linné och äldre författare blifvit upptagna under MIossa som slägtnamn, upptagas här under Laf. - De egentliga
Mossorna äro så lika till utseendet och utan synnerlig användbarhet, att få haf $v a$ egna namn i tal-eller skriftsprảket. Tảra botanister ha väl gifvit Svenska namn åt de flesta slägten, men som dessa äro underkastade oupphörlig söndersplittring, och allmänheten visst icke kommer att urskilja dem, anser jag onödigt att upptaga ifrågavarande namn. Endast några fả, som förekomma i folkspråket och som bland de af Liljeblad och Wahlenberg gifna kunna lättare úrskiljas, äro här nedan anförda.

Björnmossa, arterna af slägtet $P_{0}$ lytrichum Dicu., som i folkspråket har talrika benämningar. Särskildt upptagen.

Bullmossa, Bullemossa (Liljeblad), slägtet Splachnum L., i synnerhet $S$. luteum och rubrum L., de vackraste mossor i verlden. Wahlenberg benämner denna mossa Parasoll- och Solskärmsmossa.

Droppmossa,Tortula ruralis Eнвн., som växer på halmtak, hvilka efter regn länge droppa af den $\mathrm{i}$ mossan stannade fuktigheten.

Hvitmossa, särskildt upptagen.

Ljussläckaremossa (Wahlenberg), slägtet Encalypta Sспreв., lätt skildt genom sin klocklika mössa.

Raggmossa, slägtet Racomitrium BRTD., arter af Grimmia HEDr., eller mossor med hårspetsade blad.

\section{Rödmossa = Hvitmossa.}

Snigelmossa, slägtet Jungermainnia L.

Sotmossa, slägtet Anthecian-Enn.

Stjernmossa (Liljeblad), ${ }^{-}$slägtet Mnium L.

Svallmossa, Leucobryum glaucum H. SIPE.

Trälmossa, åtskilliga mossor, mest Hypna L. på magra ängar.

Viskmossa $=$ Björnmossa, äfven större arter af slägtet Dicranum HEDw.

Vispmossa, se särskildt.

Väderleksmossa (Wahlenberg), Funaria hygrometrica HEDw.

Väggmossa, de större arterna af Hypnum L., såsom proliferum, parie- 
tinum L. Användes att stoppa i väggar.

Mossatof, se Tof.

Mossros, f., en odlad art af Törnros.

Mossrot, f., en art af Umbellatslägtet Peucedanum L., med findelade blad och platta frukter, utmärkt för rotens brännande smak, hvaraf den fantt namnet Finsk Ingefära. Jfr Ingefära. (I Nerike skall äfven Calla $\mathrm{L}_{\mathrm{o}}$ benämnas Mossrot.)

Movippa, se Vippa.

Mulbärsträd, n., ett $\mathrm{i}$ de varma länderna talrikt slägte, med hallonlika frukter, Mulbär. Deraf odlas hos oss två arter:

Hvitt Mulbärsträd (Morus alba L.), med hvita bär. Dess blad lemna den yppersta föda för silkesmasken.

Svart Mulbärsträd ( $M$. nigra L.), hvars brunsvarta bär äro synnerligen läckra. ört.

† Multegrås, n., Vesterg. $=\mathbf{M j o ̈ d -}$

Multer, se Molter.

Munkfuat, n. (Munklöss), en art af slägtet Cynoglossum L., tillhörande de Skrufblomstriges familj, med mjukhåriga blad och med frukter som genom hakformiga piggar fästa sig vid kläderna : C. officinale $\mathrm{s}$. Har en stinkande lukt. - Jfr Hundtunga.

Munkhatt, m., se Monke och Munkskalle.

+ Munkhufvud, n., Dalsland = Smörblomma. Namnet har samma hänsyftning som Skallnacke, brukligt i Österg., och Priestcrown i Engelskan. ken.

† Munk-kål, m., Söderm.=Bläc-

Munkmössa, f., en med Missne närförvandt växt, men med han- och honblommor åtskilda, fastän på samma kolf (hos Missnet äro de blandade om hvarandra): Arum maculatum $\mathrm{L}$.
Munkmössan har en skarp, brännande smak. Kallas äfven Dansk Ingefära. - Hos Franckenius benämnes den Munkepes, hos Tillandz Munketyg. - Jfr under Munkskalle.

\section{Munkpeppar, m. $=$ Bitterfet-} knopp.

Munkskalle, m., Munkhatt, Munkmössa, allmän benämning på en art af slägtet Stormhatt, med stora, blå, hjelmlika blommor: Aconitum $\mathrm{Na}$ pellus L. eller snarare A. Cammarum $\mathrm{L}$. Kallas äfven Blåmunk.

Anm. Enligt 'Linnés Fl. Svec. skall namnet $i$ Jemtland öfverföras pà den himmelsvidt átskilda Kamillblomman.

Murgrön, Murgröna, f., en ständigt grönskande buskväxt, som förmedelst luftrötter klänger sig uppför klippor, murar o. s. v. Hedera Helix L. Murgrönan var helgad at vinets gud, och dess rankor inbjuda än till hans hyllning.

Och murgrönsrefvans helga krans sig knöt

Betydningsfullt om silfvergråa håren. STAGNELIUS 1: 135 .

Der rankan sig lindar kring lagrarnas stam

Och murgrön kring hjeltarnes stoder. BESKOW 1: 165 .

Murkla, f., en läcker vårsvamp med på öfre sidan nätådrig, oftast sockertoppslik mössa: Morchella esculenta PERs.

Stenmurkla, en med Murklan beslägtad ätlig vårsvamp, men med upphöjda, vridna åsar på mössans öfre sida: Gyromitra esculenta $\mathrm{Fr}$.

Mur-ruta, f., en art af slägtet Bergspring, med tredeladt sammansatta blad, småbladen vigglika: Asplenium Ruta muraria I.

$\div$ Murört, f., ett mycket opassande, obrukbart namn på Gypsophila murclis $\mathbf{x}$.

Musflbla, f. (äfven Musöron), en afdelning af Hökfibleslägtet, vanligen utskjutande refviga rotskott, med utmärkt små frukter: Pilosellı Fr. 
Muskot-träd, n., ett ständigt grönskande träd på Moluckerna: Myristica moschata Тнихв. Frukten kallas $\mathrm{Mu}$ skotnöt och det kärnen omgifvande skalet Muskotblomma.

Musrumpa, f., se Mustippa.

Musseron, m., en ätlig svamp af Skiflingarnes slägte: Agaricus gambosus $\mathrm{Fr}$.

Mustippa (äfven Musrumpa), f., en mycket liten växt af Ranunkelfamiljen, med bar, enblommig stängel och långt utdraget fruktfäste: Myosurus minimus $\mathrm{L}$.

† Mustörne, enligt Dalin Ruscus aculeatus $\mathrm{L}$. Förkastligt och obrukligt namn, efter Tyskans Mäusedorn.

Musärt, f., Vesterg. (Musapjask) $=$ Sparflins.

Musöron, n. pl., se Musfibla.

Musört, f., ett till Boväxterna hörande slägte: Filago L., små gråludna växter med hela blad och gyttrade blomkorgar.

Myggblomma, f., ett i kärr växande örtslägte af Nosseväxternas familj, med mycket små, gulgröna blommor: Malaxis Sw., äfven Sturmia RErou.

IIynta, f., ett artrikt slägte af Sugeväxternas familj, med nästan regelbundna, fyrklufna blommor, och mer eller mindre béhaglig aromatisk lukt: Mentha L. Utom de vilda Myntorna hafva fiera arter från äldsta tider varit odlade så väl för sin vällukt som för medicinskt bruk.

Grön Mynta (M. viridis L.), glatt, grön, med blommor i ax.

Grå Mynta (M. silvestris L.), lik den föregående, men gråluden.

Hästmynta (M.aquatica L.), blommorna i ett hufvud, bladen släta. En förändring häraf med blommori krans uti bladvecken kallas Vild Hjertansfröjd.
Krusmynta (M. crispa L.), blommorna $\mathrm{i}$ ett hufvud, bladen inskurna och krusiga.

Myskmynta (M.sativa $\mathrm{L}$.), se Hjertansfröjd. Denna odlade art är den mest välluktande af alla, vida skild från Vild Hjertansfröjd, med hvilken den dock af botanister förvexlas.

Trädgårdsmynta (M. gentilis Iso), blommorna i småludna knippen uti bladvecken. Odlad och förvildad.

Åkermynta (M. arvensis L.), blommorna i kransar uti bladvecken. Har obehaglig lukt och kallas deraf ofta Horsamynta.

Myr- ingår i flera sammansättningar, utmärkande dels arter, dels förändringar, växande i kärr, t. ex. Myrbjörk, Myrgran m. fl.

Myrag, m., ett slägte bland Halfgräsen, likt $\mathrm{Ag}$, men mycket mindre: Rhynchospora $\mathrm{V}_{\triangle \mathrm{AH}}$. Af Myragen finnas två arter, en med hvita småax ( $R h$. alba $\mathrm{V}_{\mathbf{A} \mathrm{L} .}$ ), en med bruna (Rh. fusca $\left.\mathrm{V}_{\mathbf{A B z} .}\right)$.

Myrbjörk, se Björk.

Myrbräcka, se Bräcka.

+ Myrbär, n., Ångerm. = Tranbär. † Myrdun, Myrkulla = Ängdun. Myrkong, m., se Kungsspira.

Myrlaf, se Laf.

Myrrha, f.,en välluktande kåda,som utflyter ur Balsamodendron Myrrha Lrsк, hvilket träd finnes i Arabien och Abyssinien. Omtalas flerstädes i bibeln.

+ Myrstut, m., Jemtl. = Strätta.

Myrten, m., en ständigt grönskande buske från södra Europa, hvilken hos oss allmänt odlas inom hus: Myrtus communis L. Äkta-kärlekens symbol.

Den första (kransen) var af myrten. Dermed kröntes

Den lycklige, hvars ömma tro belöntes Af den förnämsta skönhets ädla hand.

Unga flicka, i din vår. LEOPOLD 2: 291.

Bind dig myrtenkransen. FRANZĖN 1: 140. 
+ Myrtåg, se Mortåg.

† Myrtåger, f. pl., Verml. = Linnésört.

Myska, f., gemensamt namn för flere välluktande växter, såsom Myskegräs (Hierochloa odorata $\mathrm{W}_{\mathrm{G}_{0}}$ ), Myskemadra (se Madra), Myskmynta (se Mynta), Skogsmysk = Linncea borealis $\mathrm{l}$.

Måbärsbuske, m., en art af slägtet Ribs, med upprätta blomklasar och röda bär (Måbär) med fadd smak: $R i$ bes alpinum L. Jfr Linnés Öl. resa 7.

Månadsros, f., en odlad art af T'örnros: Rosa damascena ArT.

Månfiol, f., ett örtslägte af Korsblomstriges familj, med bla blommor och stora glänsande skidor : Lunaria L. - Månört, Atterbom 1: 89.

† Mångbladslaf, falskt och obrukligt namn; utgår alldeles.

Măı’a, fo, ett artrikt öṛtslägte, skildt från öfriga Måraväxter genom platta blomkronor utan pip: Galium L. Af hit hörande arter äro följande mera allmänt kända :

Allmän Måra (G. boreale L.), upprätt, med fyra blad i krans, hvita blommor, hắriga frukter.

Hvitmåra (G. Mollugo L.), uppstigande stjelk, atta blad i krans, hvita blommor, glatta frukter.

Gulmåra (G.verum L.), lik den näst föregående, men stjelken upprätt, blommorna gula. Har talrika namn i folkspråket.

Snarmåra (G. Aparine't.), med snärjande' stjelk; hänger sig medelst krokiga taggar fast vid kläder och andra föremål. Kallas vanligen Snärjegräs.
Måraväxter, Tvåhjertbladsväxter med sambladig blomkrona ofvan om den af tvenne småfrukter sammanväxta frukten, med två märken: Rubiacece Juss.

Märke, n., ett i vatten växande örtslägte af [imbellaternas familj, med enkelt parbladiga blad och femnerviga småfrukter: Sium L. Namnet tillhör ursprungligen Selleri, men är nu allmänt öfverfördt till slägtet Sium. En art har de under vatten växande bladen dubbelt parbladiga: S. latifolium $\mathrm{L}$.

† Märrbjälla, f., Dalsland $=$ Blàklocka.

Mårrblomster, n., Dalsland = Hästfibla.

Märrmynta, f., Boh. = Konig.

Märrpissegriis, n., Vesterg. = Drakblomma.

Måss, n., se Missne.

Måsterrot, f., en mångårig ört af Umbellaternas familj, med dubbelt tredelt-sammansatta blad och platta del- $\checkmark$ frukter: Imperatoria Ostruthium L.

Möblomma, f., en med Valmo närbeslägtad ört, men med långa, hornlika, trårummiga skidor: Glaucium Tours. Vår inhemska art har gula blommor: G. luteum soor.

Mögel, n., åtskilliga veka, ull-eller hårlika svampväxter, allmänna på förruttnande organiska ämnen, med frökorn $\mathrm{i}$ spetsen, dels inom en blåsa (Mucor Mrors.), dels bara i ett hufvud (Aspergillus $\mathbf{H}_{\text {тон.) }}$ eller radade i penselform (Penicillium LrNE).

- Mörklaf utgår alldeles.

Mörtgrås, n., Gotl. = Hvitfetknopp. 


\section{N.}

$\div$ Nackel, m., Nackblomster, n., ett af Liljeblad bildadt namn på Hökfibla (Hieracium L.), men utan känd härledning och som hvarken i skriftspråket eller det allmänna språket blifvit antaget. Jfr Prestnacke.

$\div$ Nafvelgräs, n. (rättare Nafvelört), föres af äldre författare ganska passande till slägtet Spikblad; i Dalins ordbok föres det till utländska slägtet Cotyledon L., men då detta är i Sverige okändt, synes det mig öfverflödigt att för det samma antaga ett Svenskt namn.

Nafrellaf, se Laf.

† Nafverlönn, f. (i Skåne Naver, efter Danskan), en buske, hörande till slägtet Lönn, med treflikiga blad, upprätta blomknippen: Acer campestre L.

\section{$\div$ Nagelgräs, $\mathrm{n} .=$ Hönsarv.}

Nagelsvamp, m., en mycket liten, ätlig svamp, som framkommer strax $\checkmark$ efter snösmältningen om våren: $A g a-$ ricus esculentus WULF.

Nagelört, f., ett artrikt slägte af Korsblomstriges familj, med små oan"senliga blommor, korta skidor: Dra$b a$ L. Den allmännaste arten deraf, D. verna $\mathrm{L}$., skiljes nu vanligen som eget slägte och benämnes Rågblomma (Smål.).

Nagglaf utgår alldeles.

Najas, f., ett under vattnet växande örtslägte, hvilket kanske rättast bibehåller Latinska namnet, såsom stamförvandt med Nate; eljest kan det ock benämnas Nateserf.

\section{Najkon, se Nejkon.}

$\div$ Nakling, m.=Tidlösa. Af dess i trädgåndsspråket vanliga metaforiska benämning Nakna Jungfrun har Liljeblad bildat Nakling, som är ett föga lämpligt namn.
Narciss, m. och f., örtslägtet $\mathrm{Nar-}$ cîssus L., skildt från öfriga Narcissväxter genom en odelad krona inom kalkbladen. Hit höra Gul Narciss (se Påsklilja), Hvit Narciss (se Pingstlilja) samt Jonqvill ơch Tazett, hvilka alla äro särskildt upptagna.

Narcissen, sörjande, som med sin blekhet klagar

Mot kärleken, hvars hämnd fórhärjade dess dagar.

OXENSTJERNA 2: 28.

Långs utför rabatten narcisserna buga

Och röra på nackarne liksom i takt. DAHLGREN $1: 420$.

Narcissväxter, prydliga lökväxter med ett hjertblad och sex standare; likna Liljeväxterna, men hafva fruktämnet under blomman: Narcissece Juss.

Nardus, f., en från äldsta tider för sin vällukt prisad växt i Ostindien, beslägtad med Vänderoten: Nardostachys Jatamansi Dec. Den af rotstocken pressade saften användes till smörjelse. "Kom en qvinna, som hade ett glas med oförfalskadt och kosteligit nardus smörjelse". Marc. 14: 3.

Narf, m., ett namn närbeslägtadt med Arv och med nästan samma betydelse, men i allmänhet tillagdt endast Narfiärterna. Liksom dirv kan det blott med bifogadt epitet användas såsom bestämdt växtnamn. Flexioner deraf äro Nägde, Nörel.

Narfgrås, n., ett mycket mjukt och vekt grässlägte, växande på våta ställen, med 1-2blommiga småax: $C a$ tabrosa P. BEavv.

Narfväxter, familjen Alsinacece Fr.; Tvåhjertbladsväxter med ledade stjelkar, motsatta blad, fembladigt blomfoder och blomkrona, enrummigt fröhus med centralt fröfäste. Hit höra Hönsarv, Spergel, Stjernblomma m. fl. Undantagsvis äro blommorna fyrdelade. 
Nata, f., är i mellersta Sverige den allmänt brukliga benämningen på Stellaria media (L.), i Göta rike Våt- eller Vassarv.

Nate, m., ett artrikt örtslägte, hvars samtliga arter äro vattenväxter med smala blomkolfvar, fyra kalkblad och småfrukter: Potamogeton L. Bland arterna förtjena följande, af allmänheten urskilda, att anföras:

Abborrnate, med de öfre bladen flytande, hinnaktiga, rodnande: $P$. rufescens Scrrad. Namnet tillägges $\mathrm{i}$ folkspråket äfven Gäddnaten.

Borstnate, med borstlika, ehuru platta blad, alltid nedsänkta i vatten : $P$. pectinatus $\mathrm{L}$.

Grodnate, särskildt upptagen.

Grofnate benämner Wahlenberg $P$. lucens $\mathrm{L}$., med nästan oskaftade, lancettlika, glänsande blad, alla nedsänkta i vatten.

Gräsnate, med grenig stjelk; de nedre bladen under vattnet gräslika, de öfre flytande bladen hinnaktiga: $P$. gramineus $\mathrm{L}$.

Gäddnate, med flytande, skaftade, lädgrartade blad: $P$. natans $\mathrm{L}$.

Alnate, med alla bladen nedsänkta i vatten, hjertlika, stjelkomfattande: $P$. perfoliatus $\mathrm{L}$.

Anm. Sảsom synnerligen eget må anmärkas, att detta örtslägte af Dalin alldeles förbigas och förvexlas med Nata.

Nateserf, m., se Najas.

Natt och dag = Lundkovall.

Nattfackla, f., Dictamnus albus L., en hos oss såsom prydnadsväxt odlad ört med hvita eller röda blommor. Den är mycket rik på en eterisk olja, som vid hög temperatur afdunstar i så stor mängd från blomdelarne, att, om hon antändes med ett ljus, hon då bildar en starkt uppflammande låga; deraf det Svenska namnet.

Nattfiol, f., örtslägtet Hesperis L., tillhörande Korsblomstriges familj, hvars äkta $\operatorname{art}($ H.tvistis L.), med smutsgula, brunådriga blommor, odlas för den vällukt dessa sprida nattetid. Det samma eger äfven rum, ehuru i mindre grad, med Allmänna Nattfiolen $(H$. matronalis L.), som har röda blommor.

Med lockar gula såsom solens,

Och kinder såsom nattfiolens. TEGNÉR 2: 16.

När på bergen och kring dalen

Aftonrodnan làgar opp,

Sjunger ljufigt näktergalen,

Ôppnas nattfiolens knopp. NICANDER 1: 431.

I tårar liljan stod, och nattfiolen

Sitt milda doft kring Floras bäddar göt. STAGNELIUS 1: 423 .

Anm. Till de ofvannämnda båda växterna hör obestridligen namnet Nattfiol; men som flere växter om aftnarne utveckla en starkare lukt, har samma namn blifvit öfverfördt äfven till dessa, synnerligast till Nosseroten och Svensk Caprifolium.

Nattskatta, f. (Tillandz), Nattskategräs, $\mathrm{n}$. (Retzius), är tydligen det Tyska Nachtschatten, Danska Natskygge, och i skriftspraiket en benämning på Solanum nigrum L., men som knappast ingått i folkspråket. Enligt Rietz har dock namnet Nattskategräs otvungen härledning af nattskata, en provinsbenämning på Läderlappen.

Neckarot, f. $=$ sprängört. Se Linnés Vestg. resa 98-100.

Neckblad, Neckblomster, i.., en allmän vattenväxt med stora, hjertlika, läderartade, flytande blad och gula blommor: Nuphav"luteum Ss. (Se Riktz Ordb.467, der flera olika benämningar på denna växt anföras.)

Kring kölen neckens blomster glimma, Och breda blad i mattor simma,

Dem ingen bölja fuktat har. GYLLENBORG 1: 190.

Neckros, f., lik näst föregående, men med mycket större, hrita blommor: Nymphoea alba $\mathbf{L}$.

Den hvita neckros reste opp

Jot soln sin blanka silfverkopp. ARNELL 37.

Fyrisån, af neckens rosor krönt. STAGNELIUS 1: 305 . 


\section{Neglantyr $=$ Lukttörne. Jfr En- geltorn.}

Neglika, Nejlika, se Näglika. (Ordet anses härleda sig från nagel, spik, stift; jfr T. Nägelein, hvarmed närmast afses Kryddnäglikan, $i$ anseende till blomknopparnes likhet med små nubbar.)

Nejkon (Najkon), n., Gotland = Backsmultron. Namnet kommer af det Ryska nika, bär, hvilket ord förirrat sig till Gotland.

Nicht, m., en från Tyskan lånad benämning på Lumrik. Se Mattlummer.

Nicktistel, se Tistel.

† Nippramsgräs = silfverört.

Njupon, se Nypon.

+ Njurlaf utgår.

Nocki, f., ett särdeles gammalt, dyrbart namn, af det nu nästan förlorade nocka, ludd. (Se Ihres Gloss.) Tilllägges mycket ulliga växter, men temligen obestämdt. Jag har hört det hänföras äfven till Musörten; lämpligast synes det mig dock tillkomma våra Svenska Cinerarier eller ock Tephroseris RErcH., ett med Boörten förvandt slägte, men med enkel hålk.

+ Nolanaber, m., Skåne, enligt Linnés Fl. Svec. n. 704 (enligt Sk. resa s. 147 : Nolanabber, i registret till boken: Nolanäbbar $)=$ Hökfibla. Namnet synes vara utgånget och är sannolikt förvridet.

Nopal, m., en art af Cactus, Opuntia coccinellifera DE.

Noppa, f., örtslägtet Gnaphalium L.; hittills förenadt med Kattfotsörten och från den skildt eudast genom tvåkönade blomhufvud. Namnet tillägges i folkspråket båda, äfvensom Harklöfvern.

Nosgräs, se Näsgräs.
Nosserot, f., ett örtslägte af Nosseväxterna; de Svenska arterna hafva två breda rotblad, hvita blommor i klase och med lang sporre: Platanthera Rior. Rotknölarne hafva afrodisiska egenskaper. Nosserotens blommor sprida om aftnarne en behaglig lukt, hvaraf de oegentligt blifvit benämnda Nattfioler.

Anm. Namnets etymologi är märkvärdig. Tvenne tydningar förekomma, begge ganska karakteristiska för växten. Enligt den ena härleder det sig frản noss, ett landskapsord, som är liktydigt med slem, hvilket väl passar till rotknölarnes slemrikhet. Enligt den andra kommer det af växtens Tyska benämning Genoss. würz, der ordet genoss, conjugium (ge har bortfallit i Svenskan), betecknar de båda förenade rotknölarne. - I Svenska folkspråket skola ock testiculi kallas nossar.

Nosseväxter, Tvåhjertbladsväxter med mycket egendomligt bildade blommor, treskaligt, enrummigt fröhus, från alla öfriga skilda genom ståndarnes förening med pistillen till en pelare: Orchidece $\mathrm{L}$.

Notblomster, n., en i de Svenska insjöarne vanlig växt med jemnbreda, inuti pipiga, tvårummiga rotblad och på stängeln klaslikt hängande hvita blommor: Lobelia Dortmanna L. De utländska, som prydnadsväxter odlade arterna af slägtet bibehålla namnet Lobelia.

Nubblaf, se Laf.

Nubbsramp, m., en liten, hård trädsvamp med gullgul disk; märkvärdig för sitt inom tallens ved krypande svamplager, hvarigenom träet snart förruttnar: Ditiola radicata $\mathrm{F}_{\mathrm{R}}$.

Nunneört, f., ett i lundar växande, tidigt blommande örtslägte, med rund stamknöl, mångdelade blad och $i$ en klase sittande (hỏs våra ịhemska arter röda) blommor: Corydalis VeNT. De allmännare arterna äro:

Finger-nunneörten, med tät stamknöl och fingerdelade skärmblad: $C$. bulbosa Pers. Förekommer mest i gamla trädgårdar. 
Håla Nunneörten,med ihålig stamknöl och hela blomskärmar: C. ca$v a\left(\mathrm{~L}_{\text {. }) \text {. }}\right.$

Lilla Nunneörten, med tät stamknöl och hela blomskärmar: $C \cdot f a b a-$ cea PEns. En af de tidigaste vårväxter i lundar.

Sibiriska Nunneörten, med hela skärmar och gulhvita blommor: C.nobilis PERs. Odlas som prydnadsväxt.

$\div$ Nyckelblomma, f., ett af Gulhvifvans. många namn; oftare säges dock Jungfru Mariæ nycklar, Himmelsny cklar.

Nyckelblomster, n., ett artrikt slägte af Nosseväxternas familj, med trenne rotknölar, klasvis sittande (mest röda) blommor med långa sporrar: $O r-$ chis L. Flera arter urskiljas af allmogen under namn af Johannis, Jungfru Mariæ, Petri nycklar; några hafva tillika sjelfständiga namn. Arter med handlikt klufna rotknölar kallas Herrans hand (se derst.). Den allmännaste bland dessa är:

Fläckiga Nyckelblomstret, med tät stjelk och fläckiga blad: 0 . maculata $\mathrm{L}$.

(Svedda Nyckelblomstret, O.ustulatı L., se Krutbrännare.)

† Nyckelgrås, n., ett af Ängskovallens många namn, antecknadti Medelpad.

Nypoubuske, m,; Dalsland Nypetorn, n., de vilda, enkla arterna af slägtet Rosa L., taggiga buskar med sköna blommor. Frukten kallas Nypon, $\mathrm{Hy}$ pen m. fl., rättast Njupon af det äldre Hjupon. Jfr Törne och Törnros. Nyponbuskens frukter insanlas för kökets behof och skiljas dervid efter mognadstiden i

Smörnypon ( $R$. cinnamomea L.), de minsta, tidigast mognande, smörmjuka frukterna.

Sommarnypon (R. mollissima Wrus.), tidigt mognande, köttiga, tagghåriga frukter. Till dessa sluta sig de stora, oftast odlade Holländska Nyponen.

Vinternypon ( $R$. canina L.), sent mognande, hårda, glatta frukter.

Nysblad, n., Österg. = Hästfibla

Nysrot, f., örtslägtet Veratrum L., Etthjertbladsväxter med stora, breda, fallade rotblad, rik blomvippa, sex qvarsittande kalkblad och tre enskaliga småfrukter. Nysroten benämnes ofta Prustrot, emedan den eger lika egenskaper.

Hvit Nysrot (V. album-L.), med hvitgröna-blommor. Växer, i Finmarken.

Svart Nysrot (V. nigrum L.), med svartbruna blommor. Odlas.

†. Nyttegräs, ett onyttigt och obrukligt namn, fördt till Kattmynta.

† Nåldyna, f. = Taskört, äfren Björkticka.

Nålkörfvel, m., en med Körfvel närbeslägtad Umbellat, med långa, syllika, kamlikt stälda frukter: Scandix Pecten $\mathrm{L}$.

千 Nålsvamp, ett $\mathrm{i}$ intet afseende utmärkt, litet svampslägte, som kan alldeles förbigås.

+ Näfta, f., ett af det Latinska $\mathrm{Ne}$ peta olyckligt bildadt namn, som hvarken har vunnit eller kommer att vinna. burskap i språket.

Näfva, f.; nyare Näbb (i äldre språkét heter näbb näf), ett artrikt örtslägte bland Tråhjertbladsväxterna, lätt skildt genom en näbblik fruktpelare, på hvilken fem småfrukter äro fästa: Geranium L. Slägtets arter äro dels mångåriga, dels ettåriga; flera af dem hafva egna namn i folkspråket, såsom:

Blodnäfva ( $G$. sanguineum $\left.L_{*}\right)$, med enblommiga blomskaft, högröda blommor.

Skogsuäfva (G. silvaticum I..), mångårig, med knölig rot, gredelina blommor. 
Stinknäfva (G. Robertianum I.o), - ettårig, utmärkt från flera andra, likaledes ettåriga arter genom sin stinkande lukt.

Ängsnäfva ( $G$. pratense น.), lik Skogsnäfvan, men har mera inskurna blad och sköna högblå blommor.

$A n m$. Genom ett olyckligt stafningsfel har man kommit att föra namnet Näfva till slägtet Slideknä. Detta kallas vanligen i södra Sverige Röknäa: i stället för $R \ddot{o}(a)$-knäa har man läst Rök-nüra och derigenom fått benämningen Näfva till slägtnamn för Polygonum. L., hvarpå den icke har aflägsnaste tillämpning, hvilket sedermera föranledt flera olyckliga sammansättningar.

Näfverlaf, Näfvermossa, se Laf. † Nägde, Ångérm. = Spergel.

Någlika, f., ett artrikt örtslägte, typ för Näglikeväxterna, skildt från öfriga slägten genom fyra eller två fjäll, som nedtill omgifva det cylindriska fodret: Dianthus $\mathrm{L}$.

Näglikor täckt bland röda pioner

Sira hvar vinkel och lukta så skönt. BELLMAN 3: 123.

Borstnäglika (D.barbatus L.), med lancettlika blad, blommorná i en jemn qvast.

Praktnäglika (D.superbus I..), med röda blommor i gles vippa, kronbladen delade i hårfina flikar.

Sandnäglika (D.arenarius L.), med kronbladen som hos den föregående, blommorna hvita, stjelken enblommig. Sandnäglikan uppfyller vid midsommartiden luften med en doftande aromatisk vällukt. Jfr Linnés Sk. resa 74. - Liknar mycket den utländska, stundom odlade Fjädernäglikan ( $D$ : plumarius L.), men denna har isgrått, grenigt örtstånd.

Saronsnäglika (D. Armeria L.), se Saronsblomster.

Trädgårdsnäglika (D. Caryophyllus L.) har grenig stjelk, ensamt sittande blommor, i kanten tandade kronblad.
Ängsnäglika (D. deltoides L.), lik den föregående, men flere gånger mindre och har blott två smala skärmblad under fodret.

\section{Näglikekummer, se Kummer.}

Näglikeväxter, familjen Silevicece Lrxps., Tråhjertbladsväxter med ledade stjelkar, motsatta, enkla blad, sambladigt blomfoder, sköna fembladiga blommor och centralt fröfäste.

\section{+ Näsgräs, Nosgräs, Dalarne =} 1) Röllika, 2) Nysrot.

Nässla, f., ett allmänt bekant slägte, tillhörande Tråhjertblads-och kronlösa växterna, hvilket genom sina stickande hår gör sig lätt kändt: Urtica I. Kallas äfven Nätla (fornsv. nætla), Näta, Nät.

Jag är en nässla; den mig rör

Får känna hvad min qvickhet gör.

Men slutlig man mig agar

Och kål på mig tillagar. V. DALIX 5: 356 .

Brännässla ( $U$. dioica L.), mångårig, med hjertlika blad.

Etternässla (U. urens L.), ettårig, med ovala blad.

Hampnässla ( $U$. cannabina L.), mångårig, med flikiga blad; liknar Hampa och lemnar; såsom denna växt, äfven tågor.

Anm. Den sistnämnda är vida skild från allmogespråkets Hampnässla, en art af slägtet Dån. I detta språk kallas flere Sugeväxter nässla, t. ex. Blindnässla, Bonässla, Asknässla, hvilka icke ega den ringaste förvandtskap med Nässleslägtet.

Nässleklocka, se Blåklocka. $\div$ Nässlesilke, $\mathrm{n} .=$ Allmän Snarrefva.

Nästrot, f., ett örtblad saknande slägte af Nosseväxternas familj, med i en knippa samlade rotgrenar, liknande ett skatbo: Neottia Nidus anis,(L.).

Yörel, Nörla, f., mycket små Narfväxter med syl-lika blad, treskalig frukt: Alsine WG. Namnet, tillagdt äfven Lepigonum $\mathrm{F}_{\mathrm{r} .}$ (se Fjällnarf), tillhör egentligen Norskan. 


\section{O.}

$\div$ Obär, Dal., se Öbär.

Odonbuske, $m$., en art af slägtet Vaccinium L., med årligen affallande löf och mörkblå bär, liknande Blåbär, men smaken äcklig: $V$. uliginosum $\mathbf{L}$. Bären kallas Odon, hos äldre författare Odensbär. I stor mängd förtärda, förorsaka de yrsel och hufvudvärk; deraf deras namn (Isl. $\delta \delta r$, galen, rasande).

Odört, f., en narkotisk ört, tillhörande Umbellaterna, känd af sina klotrunda frukter med ojemna åsar, sina mycket sammansatta blad och sin fräna lukt: Conium maculatum L. Namnet är ursprungligen och hos Harpestreng samt alla andra äldre författare tillagdt Sprängörten (Cicuta L.), men numera allmänt antaget för Conium.

+ Ofris, f., det Latinskà Ophrys L., hvilket slägte nu är upplöst i flera, så att man icke kan föra namnet till någotdera, ehuru Flugblomman dermed troligen menas.

+Oleander, $\mathrm{m} .=$ Nerium Oleander L. Jag har alltid hört denna, endast inom hus odlade buske kallas Nerium. Intetdera namnet bör likväl upptagas i en Svensk ordbok, om ej i ett bihang.

\section{Oleaster, m., se 0liv.}

Olgon, Olvon, n., se Olvonbuske.

Oliv, Olivbuske, m., en i södra Europa och Orienten växande, ständigt grönskande buske (Olea europara L.), af hvars bär pressas olja (matolja och bomolja). Den vilda busken kallas Olenster.

På en ringa lofvande mark, oländiga kullar,

Klappergrus, med törne beväxt, och magrare lera

Trifvas Minervas skog och olivens lifliga stammar.

Tecken dertill oleastrerna ge, som ymnigt i trakten
Skjuta sin växt och beströ med de vilda frukterna jorden. ADLERBETH 77. ... Vårda den feta oliven, helgad åt freden.

Olivlaf, se Laf. Dens. 84. † Olivlöf, $\mathrm{n}$., Vesterg. = Murgrön. + Oljoblad, n., blad af Oliven. TFGNÉR 3: 72 .

Oljoträd, n., benämnes Oliven i bibeln. "Han varder afhemtad... såsom ett oljoträ bortfäller sitt blomstern. Job 15: 33. - "Än i dag grönskar Cedern på Libanon och Oljoträdet i örtagården vid Gethsemanen. ERIES Bot. utfl. 1: 94 . Två oljeträd planterade man såg Vid grottans öppning. STAGNELIUS $1: 464$.

01jpalm, f., ett slägte bland palmarterna i Guinea, af hvars frukter Palmoljan erhålles: Elais guineensis L.

† Oljrättika, anförd i Dalins ordbok. Hvilken växt dermed förstås, vet jag icke.

+ Olmegrås, se ölmegräs.

Olsmessaskopor (01s-skopor) och Olsmess-umbell,. olämpliga. namn i Dalarne, det förra på Skogsnäfvan, det senare på Röllikan, hvilka intet afseende förtjena.

Olvonbuske, m., en prydlig buske af Fläderväxternas familj, med tlikiga blad, stora hvita blomkransar, i hvilka kantblommorna äro mycket större och ofruktsamma: Viburnum Opulus L. Frukten kallas Olvon (Olgon), egentligen Ulfbär. - Jfr Elnaträd.

\section{+ Oragräs, vanligen Orragräs,} sällan Orengräs, n., Smål. med fl. st. = Ängskovall.

Orange, m., en vanlig benämning på Pomeransträd, men tillägges äfven andra växter af Citronslägtet. Häraf namnet orangeri på drifhus, emedan 
sådana först anlades för Orangeträdens odling.

Der skönt orangen ibland lagern spirar

Iled silfverblommor och med frukt af guld.

BESKOW 1: 157.

+ Oransört, f., Skåne = Allmän Stålört.

+ Orkorn (af or, mal), n., Vesterg. $=$ Kikbär.

Orleanaträd, n., ett resligt träd i de varmare delarne af Amerika, med hjertlika blad och stora, sköna, rosenröda blommor: Bixa Orellana L. Dess frön omgifvas af ett ämne, som lemnar färgstoftet Orleana.

Ormax, n., ett litet grässlägte med fjällikt öfver hvarandra liggande blommor i enkelt ax, liknande en ormstjert: Lepturus $\mathrm{R}$. BR.

Ormbunke, m., ett slägte bland Bräkenväxterna, med i tufvor eller bunkar växande blad med runda sporplättar på undre sidan: Aspidium Sw. Tvärt emot både härledning och alla äldre författare har man hänfört namnet till hela Bräkenfamiljen.

Ormbär, n., en mångårig växt med fyra i krans omkring stjelken sittande blad, fyrtaliga blomdelar och svarta bär: Paris quadrifolia $\mathrm{L}$.

Anm. I folkspråket öfverföres namnet till flera vilda, icke ätliga bär, t. ex. Trolldrufvans samt arternas af slägtet Solanum I., och på Gotland skall Vägtorn benämnas Ormbärsträd.

†Ormgräs, n., Dalsl.=Blodnäfva. - Ordspråk: "ormen gömmer sig i ormgräs" (latet anguis in herba. Virg.).

+Ormkagge, m., Verml. $=0$ rmbunke.

+Ormnäfva $=$ ormrot. En alldeles falsk sammansättning af det missförstådda $N a ̈ f v a$.

+ Ormris, n., Hels. = Örnbräken. - Om de med orm flerfaldigt sammansatta provinsnamnen på Örnbräken, se RiETz Ordb. 489.
Ormrot, f., en afdelning af slägtet Slideknä med mångåriga, vridna rotstockar (Bistorta Touns.) och ett ax i toppen: Polygonum L. Arterna äro:

Liten Ormrot ( $P$. viviparum L.), med hvitt, lökbärande ax.

Äkta Ormrot ( $P$. Bistorta I. $)$, med rödt ax utan smålökár.

+ Ormskalle, m., Gotl. = Guckusko.

+Ormskallrebräken, n., Wahlenberg =Läketunga.

† Ormstingsgräs, n., Ormstingsrot, f., Finl. = Tulkört.

+ Ormtunga, f. = Läketunga.

† Or-mylja, f., enligt Wahlenberg = Brudbröd.

+ Ormöga, n. = Rifva. Ett af botanister bildadt, men för en växt olämpligt namin, och eljest obrukligt.

+ Ormört, f., Dal. = 0rmrot.

+ Orne, m., Vesterg. (Gäsene härad) $=$ Ask. Namnet torde komma af Lat. ornus.

Orselj, m., ett blått färgstoft, som erhålles af lafslägtet Roccella, företrädesvis från Canarieöarna. Jfr Orseljlaf.

+Osteblomma, f., norra Boh. $=$ Röllika. Namnet har blifvit härledt från os, lukt; men kommer sannolikare, enligt Rietz, af $y$ sta.

Otterbär, se Utterbär.

Oxbärsbuske (egentligen 0xelbärsbuske), m., en liten, inhemsk buske, hörande till Kärnfruktträden, med äggrunda, helbräddade blad, på undre sidan hvitludna: Cotoneaster vulgaris Lixdr. Bären likna Oxelbär, hvaraf namnet.

Oxel, f., utgör jemte Rönnen slägtet Sorbus x., tillhörande Kärnfruktträden, men lätt skildt genom sina mångblommiga blomqvastar och sińa bär med hinnaktiga kärnhus. 
Finsk 0xel (S. fennica K.ass) har de nedre bladtlikarne fria och bären syrliga, såsom Rönnen. Kallas äfven Suroxel (Rosl.), 0xelrönn.

Norsk Oxel (S. Avia Crastz), med enkelt sågade, på undre sidan hvitludna blad.

Svensk 0xel (S. scandica $\mathrm{Fr}_{\mathrm{s} .}$ ), med thikiga och sågade blad.

$\div$ Oxgräs, n. = Nosserot.

Oxlägg, 0xläg`a, f. (förskämdt uttal är $Y x l a ̈ g g)=$ Gulhvifva. Namnet förekommer äfven hos våra äldre författare och i Engelskan.

Oxläggan, sippans bror, som, knappt ur drifvan frälsad,
Ảr af det trägna bi som vårens förstling helsad. OXENSTJERNA 2: 122 . ört.

Oxtunga, 0xtungört, se Tung-

Oxtungsvamp, m., en saftig, på ekstubbar växande, rödbrun svamp med gula pipor på undre sidan: Fistulina hepatica $\mathrm{F}_{\mathrm{n}}$. Svampen har genomskuren mycken likhet med en oxtunga och räknas till de läckrare svamparne.

† Oxöga, n., en af äldre författare antagen benämning på Krageblommorna och ännu bruklig i Skåne.

† Oxöron, n. pl.= Backvippa.

\section{P.}

$\div$ Paddbår, n., hänföres vanligast till Trolldrufvan, men tillägges äfven andra växter, som benämnas 0rmbär, Trollbär, Villbär.

$\div$ Paddfot, m. = Rifva.

$\div$ Pallgräs, $n$., Marstrand $=$ Bitterfotknopp.

Palm, f., Palmtriid, n., en gemensam benämning på träd tillhörande familjen Palme Ausr.: Palmerna, som af Linné kallas växtrikets furstar, uppnå en utomordentlig böjd; de hafva enkla stammar med en yfvig bladtofs i spetsen. - De vigtigare slägtena äro särskildt upptagna. Jfr Dadelpalm.

Ön var glad .och skön, Rik på palmer, som dem bödo

Ymnigt både bröd och must. FRANZEXX 1: 305 .

I lustgården skimrar en källa, Af viftande palmer bekransad. STAGNELIUS 2: 433.

Palmer, f. pl., kallas blombängena af Sälg, som blommar omkring palmsöndagstiden, med hvilka fordom hos oss kyrkorna sirades, såsom i de varma länderna med verkliga palmer. (Från Skandinavien har namnet och bruket öfvergått till Northumberland i England.)

†Palmmossa, f., obestämdt, obruk'ligt namn. Utgår alldeles.

Palsteruacka, f., en allmänt odlad köksväxt af Umbellaternas familj, med lång, hvit, köttig rot: Pastinaca sativa L. - Den Vilda Palsternackan har tunn, träaktig rot. Jfr Bolmört.

† Paltpotates, en flyktig, tillfällig benämning, som ej förtjenar att upptagas i en ordbok öfver Svenska spraket.

†Pantofller, m. pl., en Skinsk förvridning af det Tyska Kartoffel = Potates.

Papyrus, m., ett till Cypergräsen (ingalunda Säfslägtet) höraude. Halfgräs, hvars blad fordom användes i stället för papper: Cyperus Papyrus 
1. (Dess af Dalin anförda benämning Papperssäf är origtig.)

+Paradisfikon, $\mathrm{n}_{0}=$ Bananas.

Parasit, m. "De bladlöse (växter) äro mest Parasiter, utan egen rot, växa på andra träd eller rötter, otacksamme gökar emot sin amman. LINné Delic. nat. 19.

+ Parasollmossa (se Bullmossa) utgår.

$\div$ Parasollpalm, f., ett namn, passande till de flesta Palmer. Det föres i Dalins ordbok till Corypha umbraculifera $\mathrm{L}$. Se Solfjäderpalm.

+ Partrådar (hos Liljeblad algslägtet Zygnema AG.) utgår alldeles.

Passionsblomma, f., en i orangerier odlad växt (Passiflora ccerulea L.), i hvars blomma man trott sig finna afbildade alla verktyg vid Kristi korsfästning.

Patientia, f., 'en odlad köksväxt af slägtet Syra: Rumex Patientia L.

Pelargonie, f., det Grekiska $P e$ largonium Heirr., ett förr med Näfva förenadt örtslägte, men skildt genom oregelbunden blomkrona: Flera arter deraf odlas inom hus som prydnadsväxter, tillförene kallade Geranier. Pelargoniernas fädernesland är Cap.

†Penningblad, n., Bromelius $=$ Dyblad.

Penninggräs, n. =1) Höskallra, se Linnés Gotl. resa 238; 2) Skärffrö.

Penninggräset... skallrar med sitt frö. OXENSTJERNA $2: 27$.

Penningört, f., en krypande ört med runda blad och ensamma i bladvecken sittande blommor: Lysimachia Nummularia L. Jfr Videört.

\section{Penselrost, se Rost.}

Peppar, m., namn på åtskilliga kryddväxter med skarp, brännande smak. 1) Den nu brukliga Pepparn erhålles från Ostindien af slägtet Piper x., med $i$ ax utan all beklädnad sittande blommor; man har deraf flera slag, såsom Hvitpeppar, Svartpeppar, Starkpeppar, Långpeppar. Denna peppar var känd redan af de gamle Grekerna; men innan sjövägen till Indien blifvit upptäckt, erhölls i allmänhet 2) Peppar från Pepparkusten i Guinea af Habzelia athiopica och $H$. aromatica Drc. (Negerpeppar eller Ethiopisk peppar). - 3) Andra skarpt smakande växter, använda såsom krydda, t. ex. Cayennpeppar, vanligen kallad Spansk Peppar, som är frukten af Capsicum annuum L., m. fl. arter. - Jfr Kryddpeppar. - Äfven inhemska örter med brännande smak, t. ex. Tibast och Pilört (Polygonuin Hydropiper L.), har man kallat Peppar.

Pepparbuske, m., Skåne $=$ Tibast.

Pepparling, m., flera arter af Mjölkskiflingarne med skarpt brännande smak, dock anses några ätliga, t. ex. Lactarius iurpis $\mathrm{Fr}_{\mathrm{r}}$ och piperatus Scop.

Pepparmynta, f., en odlad apoteksväxt: Mentha piperita L.

Pepparrot, f., en som matkrydda allmänt odlad ört, hörande till Korsblomstriges familj, med hvita blommor och köttig, skarp rot: Nasturtium Armoracia Fr.

Perer, Peror, ett af Linné under hans Skånska resa (se s. 398) antecknadt namn på Stellaria Holostea L., hvilket nu sannolikt är utdödt. Troligen har det hetat perter", pärter (af det i landskapsmål förekommande pärt, häst), $i$ anseende till växtens uppgifna bruk vid hästsjukdomar.

Perldrufva, f., en odlad Liljeväxt med bar stängel och blå, klotrunda, i klase sittande blommor: Muscari, af hvars arter $M$. botryoides MrL. är den vanligaste. Fördes fordom till Hyacintslägtet och kallades då Perlhyacint, 
Drufhyacint, men är till slägte skild från de verkliga Hyacinterna.

Perlgrås, $\mathrm{n}_{0}=$ stenfrö. Om detta senare namn (öfversättning af det Grekiska Lithospermum) ej vore allmänt antaget, skulle jag föredraga Perlgräs, såsom inhemskt. Det förekommer hos Franckenius, Tillandz, Bromelius.

Persika, f., Persikoträd, n., ett träd af Mandelslägtet, med köttig stenfrukt: Amygdalus persica L. Så väl trädet som frukten kallas vanligen Persika.

Förfiningen är skön, men ofta får man

Att under ytan, ljuf och len, känna,

Göms, som i persikan, en sten. FRANZĖ 1: 357 .

Persilja, f., en bekant köksväxt af Umbellaternas familj, med små gulgröna blommor: Petroselinum sativum HoFrs. Man har flera förändringar deraf, t. ex. Kruspersilja, Rotpersilja.

† Perubalsam, se Balsamträd.

+Pestilensblomma, f., Gotland = Röllika.

Pestilensrot, Pestört, f., en rödbrun art af slägtet Skråp: Petasites officinalis Зовмон. Ansågs fordom för preservativ mot pesten och odlades derför ofta i trädgårdar; men rerkligen inhemsk är den i södra Skåne.

ster.

$\div$ Petri nycklar, se Nyckelblom-

† Pigekrut, n., Smål. = Lumrik.

$\div$ Pigepattar, m. pl., Skåne $=$ Kattfotsört.

†Pigesairkar, m. pl., Skine = Ängkrasse.

Piggfrö, n., ett slägte bland Șkrufblomstrige, med blommor såsom Ögonblommans, men med taggiga frukter: Echinospermum Sw.

$\div$ Piggtistel, se Tistel.

Pil, f., Piltriid, n., ett artrikt slägte bland Fjunhängeväxterna, när- mast beslägtadt med Poppel. Pilslägtet (Salix L.) fördelas i flera underafdelningar med sjelfständiga namn, hvilka särskildt anföras. Vi upptaga här nedan endast de allmännare, egentliga Pilarne. - De växa skola såsom grås, såsom pilträ vid vattubäickarn. Es. 44: 4 .

Sin nakna topp de ruska, flodens pilar. STAGNELIUS 2: 545.

Pilträden bära gallgula fransar. DAHLGREN 1: 372.

Daggpil, blommar på bar qvist, tidigast af alla Pilar; grenarne äro brunfioletta, öfverdragna med grå dagg: S. acutifolia $\mathrm{W}_{\text {ILLD. }}$ och pruinosa $\mathrm{W}_{\mathrm{ENDL}}$.

Grönpil, blommar, såsom alla de följande, med halfutslagna blad, hvilka på denna äro glatta och gröna; grenarne upprätta: $S$. viridis $\mathrm{F}_{\mathbb{R}}$.

Hvitpil, lik den föregående, men har af hivit ludd silfverglänsande blad: S. alba $\mathrm{L}$.

Jolsterpil, se Jolster.

Knäckepil, har två ståndare, utspärrade, mycket sköra grenar: $S$. fragilis $\mathrm{L}$.

Mandelpil, har tre ståndare, affallande bark, mycket sega grenar: S. amygdalina $\mathrm{L}$.

Sörjande Pil eller Babylonisk Pil, har utomordentligt smala, till marken nedhängande grenar: S. babylonica $\mathbf{L}$. Denna är mycket ömtålig för vårt klimat; de öfriga odlas i mängd.

Pilört, f., en underafdelning (Persicaria $G$ srrv.) af slägtet Slideknä, med lancettlika blad, liknande Pilars, och fem till sex ståndare, två stift, blommorna i ax: Polygonum L.

Brännande Pilörten har smala, glesblommiga ax, brännande smak: P. Hydropiper L.

Milda Pilörten har tätblommiga ax, mild smak: P. Persicaria L.

Vatten-pilörten har blott fem stândare och, i sin rena form, flytande blad: P. amphibium $\mathbf{L}$. 
Pimpinell, f., en ört af Brumväxternas familj, med runda blomhufvud, men utan kronblad: Poterium Sanguisorba I. Användes till likörberedning.

Vår lilla frukost vi framställa:

Rỏdt vin med pimpinella.

BELLMAN 3: 276 .

Anm. Bör ej förblandas med örtslägtet Pimpinella.

Pingstlilja, f., en art af Narciss, med enblommig stängel och hvita blommor: Narcissus poëticus $\mathbf{L}$.

Messingskronan jemväl nyskurad blänkte från hvalfvet,

Och i stället för ljus pingstliljor i piporna sutto.

TEGNÉR 2: 53.

Pinier, f. pl., de nötlika, ätliga fröna af ett med vår Tall beslägtadt träd i södra Europa, Pinus Pinea L. Äfven trädet kallas Pinie.

† Pinskorf, se Skorf.

Pion, m., en allmänt odlad, praktfull prydnadsväxt, tillhörande Ranunkelfamiljen: Pceonia officinalis RExz.

Pipdån (Pipsör Hels., Piptå Medelpad) = Dån.

Piphven, f., en art af slägtet Rör (Calamagrostis silvatica $\mathrm{DEO}_{\mathrm{O}}$ ), hvilken af Linné fördes till slägtet Hven och deraf fick det origtiga slägtnamnet. Användes till piprensare; derifrån härleder sig artnamnet.

Piplök, se Lök.

Pipnåssla, - f., Dal. = Plister.

+ Pirkum, se Hirkenpirk.

Pisang, m., ett af de ädlaste trädslag, tillhörande Etthjertbladsräxterna, utmärkt genom sina stora enkla blad och läckra frukter: Musa paradisiaca L. Härstammar från Ostindien och odlas nu i alla hetare klimat.

†Pjuska, f., Pjåsk, n. = Spergel. + Plattlaf, rent förkastligt namn.

Plister (Blisträ Finl.), m., ett allmänt örtslägte af Sugeväxternas familj, med en liten fri tand på ömse sidor om blomkronans svalg: Lamiun L.
Hvitplister, med-hvita blommor: L. album $\mathrm{I}$.

Rödplister, ettårig, med röda blommor: L. purpureum L.

Plommonträd, n., ett stenfruktträd af Slånslägtet, med stora, aflånga, välsmakande frukter, kallade Plommon: Prunus domestica L. Man urskiljer två artförändringar: Gula och Röda Plommon.

Plommon, gula som vax.

ADLERBETH 15.

De plommon, dem du skådar

I mogning svigtande på smala stjelkars trádar,

Än målar guldets färg, än purpurn deras skal.

Pluggskifling, Pluggsvamp, m., en större, såsom ätlig uppgifven svamp af Skiflingarnes grupp, med inrullad, luden kant och greniga, från hatten lätt skilda lameller: Paxillus involutus $\mathrm{Fr}$.

+ Plumagekorn = Skyffelkorn.

Pockenholz, äfven Franzosenholz, m., ett i Vestindien inhemskt träd (Guajacum officinale $\mathrm{L}$.), hvilket användes i medicin och ansetts som specifikt emot venerisk sjukdom.

+ Poleja, f., af Lat. Pulegium (Mentha Pulegium L.), ett efter 'Tyska kräuterbücher anfördt namn, som väl upptagits af äldre författare, men aldrig vunnit burskap i vårt språk.

Polört, f., en liten tufvig, ständigt grönskande fjellört, med trerummigt fröhus: Diapensia lapponica $\mathrm{L}$. Af alla fullkomligare växter är Polörten den mest härdade mot kölden.

Pomeransträd, n. (Citrus Aurantium L.), en art af Citronslägtet, med stor brandgul frukt, kallad Pomerans (af Lat. pomum aurantium).

Det träd från Maltas $\dddot{o}$, hvars evigt gröna krona

Emellan blommans snö är af sin frukt förgyld,

Ser länge der sin topp af pomeranser fyld.

OXENSTJERNA $2: 154$. 
Poppel, f., ett artrikt slägte bland Fjunhängeväxterna, med breda blad och åtta ståndare: Populus L. Blommar på bar qvist. Jfr Asp. - Af namnlikheten (populus, peuple, folk) har Poppeln blifvit ansedd för folkfrihetens symbol.

Skönast är asken i skogen,

Popplen på flodens brädd, och tallen på hjessan af berget. ADLERBETH 37.

Balsampoppel, utrnärkt genom sin vällukt och sina klibbiga knoppar: $P$. balsamifera $\mathrm{L}$.

Silfverpoppel, har af hvitludd silfverglänsande blad: $P$. alba $\mathrm{L}$.

Svartpoppel, har utspärrade grenar, glatta, triangelformiga blad: $P$. nigra L. Kallas äfven Poppelpil.

Pyramidpoppel, lik den föregående, men med korta, upprätta sidogrenar: P. pyramidalis Roz.

\section{+ Porlaf utgår alldeles.}

Pors, m., en på sumpiga ställen växande buske af Hängeväxternas grupp, med stark aromatisk lukt: Myrica Gale L. Användes fordom i stället för Humle till öl; som deraf blef mera rusgifvande och äfven förorsakade hufvudvärk. Porsen kallades $\mathrm{i}$ anledning af detta bruk Skogshumle.

Getpors = Sqvattram.

Portulak, m., en ettårig, saftfull trädgårdsväxt med angenäm syrlig smak, hvilken anrättas som spenat: Portulaca oleracea $\mathbf{L}$.

Potates, Potatis, äfven Potat eller Potåt ( $\mathrm{pl}$. potäter), m., den genom sina stärkelserika stamknölar vigtigaste och oersättligaste af alla våra odlade växter: Solanum tuberosum L. Örtståndet af potatesplantan kallas Potateskål, -blast, -ris. Växten härstammar från Amerikas bergstrakter. Potäterna blefvo i Sverige först införda af Alströmer på 1720-talet, men ej förr än på 1760-talet fingo de allmännare spridning.
Ãdlaste växt försynen de dödlige gaf var Potates.

(nSolana, quibus nil majus melinșve fata terris donaceren, коOH.)

$\div$ Potentill, det Lat. Potentilla, på ren Svenska Fingexört.

Prakt- brukas ofta vid artnamn, mest för trädgårdsväxter, t. ex. Praktnäglika, Praktlilja, Prakt-cactus $\mathrm{m}$. fl. Men att använda ett Svenskt ord i sammansättning med Latinskt namn (t. ex. "Prakt-cactusi) är stötande.

+ Prendling, m., ett af Liljeblad bildadt namn efter Lat. Prenanthes $\mathrm{I}$. $=$ Skogs-laktuk.

† Prengräis, n., Retzius = Färgginst. Källan för namnet är mig okänd.

Prentebär, n., se Liguster.

Prestkrage, -nacke, -skalle, m., se Krageblomma.

Prestnacken lyste med nystïrkta kragar.

DAHLGREN $1: 400$.

†Prestkål, m., Boh.=

+Prestlöss, Skåne = Munkfnat.

Pricklaf, se Laf.

+Provinsros, f., en odlad art af Törnros: Rosa centifolia $\mathbf{L}$.

Prustkåda, f. (på Latin Euphorbium), den stelnade mjölksaften hos flera köttiga arter af Törelslägtet, t. ex. Euphorbia antiquorum L. i Orienten, E. officinarum L. i Afrika, m. fl. Ett skarpt, drastiskt läkemedel.

Prustrot, f., ett utländskt, men. ofta odladt örtslägte af Ranunkulaceernas familj, med pipiga honungshus (kronblad) och mångfröiga småfrukter: Helleborus $\mathrm{x}$.

Grön Prustrot, med gröna blommor: H. viridis Is. Mindre skarp än den följande.

Svart Prustrot, med hvita blommor: $H$. niger L. Blommar äfven under blida vintrar och de första vårdagarne. Roten är mycket skarp; 
pulveriserad förorsakar den häftig nysning.

†Psalmbål, n., Gotl.=Blåhallon.

$\div$ Puggehatt, m. (af pugga, groda), Skånsk benämning på svampar med hatt, t. ex. Champignoner.

†Puggemat, ń. (af pugga, groda), Skåne = Andmat.

+Puggerocka, f. $=$ Åkerfräken. läder.

† Pukaläder, n., Hall. = Snufve-

+ Pukaris, n., Hall. = 1) Besksöta ; 2) Lonicer'a Caprifolium L., se Caprifolium.

\section{Pukhvete, se Kohvete.}

Pumpa, f., en Gurkväxt, hvars frukter uppnå en utomordentlig storlek: Cucurbita Pepo L.

Punga, f., en mångårig ört, tillhörande Hvifveväxterna, med runda blad och små hvita blommor: Samolus Valerandi L. Växer på hafsstränder. Namnet är lånadt ur Tyskan och Danskan. (Beccabunga är sammansatt deraf.) Jfr Bäckböna.

\section{Purjolök, se Lök.}

Purpurvinda, f., kallar Franzén en art af slägtet Vinda, vanligen odlad nnder namnet Menniskolif: Convolvulus purpureus $\mathrm{L}$.

Du sköna sinnebild af menskolifret! -Hvar morgon slår du nya blommor ut, Hvar afton vissna de. Ack, re'n förut,
Bäst de sin purpurglans mot dagen höja,

De blekna, fallna, sin förvandling röja.

Purrhafie, se Hafre. FRAN7Kx b: 129.

Pyramidpoppel, se Poppel.

Pyttor, f. pl., allimännast brukliga namnet på den odlade förändringen af Vätteljus, med röda, pipiga blommor: Rödpyttor (Bellis perennis L.).

Påfälle, n., ett parasitiskt, svart svampslägte af Rostfamiljen, hvilket angriper grässtrån och gör stor skada på̀ sädesslagen: Puccinia Graminis PERs.

Pisklaf, se Laf.

Påklilja, f., en art af Narciss, med enblommig stängel och gula blommor: Narcissus Pseudonarcissus $\mathrm{L}$.

Päronträd, n., ett bekant kärnfruktträd: Pyrus communis L. Frukten kallas Päron. Man har deraf talrika förändringar, som höra till det speciella trädgårdsspråket. De vigtigaste tecknar OXENSTJERNA :

ïn bland renetters vixt, som tynga böjda grenar,

Ditt gröna päronklot, Bergame, med sötma fylls

Utmed Beurréers frukt, som spetsas och förgylls.

2: 150 .

Päronträdet med ympning förmås att baira dig äpplen. ADLERBETH 72.

† Pärr, m., Gotländsk benämning pi̊ mindre Starrarter.

\section{Q.}

+ Qvalkebär, n., Gotl. = 0lvon. Qvaller, Sqvallerkål, m., en mångårig ört, tillhörande Umbellaternas familj, med vidt krypande rötter och tredelade, dubbelt sammansatta blad: AEgopodium Podagraria L. Qval- lern är ett af de svåraste ogräs på odlad jord.

Qvanue, n., en storväxt Umbellat med tjock, pipig stjelk och klotrunda blomflockar, omgifna af uppblåsta bladslidor: Archangelica officinalis 
Horrss. - Från slägtet Strätta skiljes det genom fria frön inom delfrukterna. - Roten af Qvanne är mycket använd $\mathrm{i}$ medicin. Qvannet nutgör Lappens både läckerhet och enda kryddan. RETZIUS 1: 50 .

Qvassia, f., den raspade veden af Quassir amara L., ett träd i Surinam med parbladiga blad, blomklasar i toppen och stora rödletta blommor. Qvaš sians ved är utomordentligt besk; användes i medicin, äfvensom till gift för flugor. floka.

† Qvesgräs, n., Ångerm.= Björn-

Qreslaf, se Laf.

Qvesrot, f., Liljeblad = Hundrofva.

\section{Qvesved, m. = Besksőta.}

+Qvesiirt, f., ett namn som hos äldre författare tillägges sâ väl Nagelört som Backbränna.

Qvickrot, f. (provinsnamn: Qvicka, Qveka, Qvekare, Qvicktågor), ett genom sina långa; ledade, krypande rotstockar mycket besvärligt ogräs, med enkelt ax: Agropyrum repens $\mathrm{P}$. BEavv. - Har förr varit förd till Hveteslägtet och deraf benümnd Qvickhvete.

Qvittenträd, n., ett med Apeln närbeslägtadt kärnfruktträd, kändt af sina "lenfjuniga äpplen" (ADLERBETH 15): Pyrus Cydonia L. Cydonia vulgaris PErs. Utaf deras kärnar erhålles s. k. Qvittenslem.

\section{R.}

† Rackbär, n., Dal. = Blåbär. (Af racka, hund.)

† Rack-kummin, m., Dal. = Hundkax.

Radis, Radisa, f., se Rädisa.

Ragglaf = Skägglaf.

Raggmossa, se Mossa.

Rajgräs, n., en i senare tider inkommen benämning på Allmänna $R_{\theta}$ pet (Lolium perenne L.), men härleder sig ej, såsom det vanligen uppgifves, från Engelske botanisten Ray's namn, ntan af det Franska Ivraie, som är en benämning på Dårrepe.

Ramme, m., ett i skogstrakter och i vestra Sverige ytterst ymnigt Halfgräs, som bekläder alla mossar: Scirpus caspitosus $\mathrm{L}$. Af allt hö är Rammehö det sämsta.

Rams, m., ett mycket gammalt och för de Germaniska språken gemensamt namn (Angl.Sax. hramsa, Eng. ram'sens, ramsons, buclerams, 'Tysk. ramsel, ramser, rams), men olika tillämpadt; synes rättast tillkomma Convallarice I.. och lämpligast bibehållas för det derifrån afskilda slägtet Polygonatum Toun., med bladig stjelk och cylindriska kronor. Detta benämues på olika orter Bockrams, Getrams. Men äfven Chamoenerion Scop. kallas Rams, Elgrams.

Ramslök, m:, en art Lök, till blad och blommor liknande Konvaljen, men med stark löklukt: Allium ur'sinum I. Se Linnés Gotl. resa 169.

Randgrås, n., en allmänt odlad förändring af Flen, med hvitrandiga blad: Digraphis avundinacen Trux., v. picta $\mathrm{I}$.

Ranka, f, se Vinranka.

Ranke, m., enligt Liljeblad namn på slägtet Enanthe Las. Namnet är 
öfverflödigt, emedan sagda slägte numera förenas med stäkra.

Ranunkel, m., kallas i poesi slägtet Solöga, Ranunculus $\mathrm{L}$.

En bladrik ranunkel.

OXEXSTJERNA 2: 121.

Smör så gult som en ranunkel.

TEGNE்R 1: 218.

Ranunkulaceer, en talrik familj bland T'våhjertbladsväxterna, med fria foder- och kronblad, talrika på fruktfästet fästa ståndare och fiere fria småfrukter: Ranunculacece Juss. Hit höra Ackeleja, Sippa, Solöga m. fl.

Rapsat, m., en artförändring af Gotlandsrofvan, med tunn rot: Brassica Napus L, v. oleifera अовхсп. Plägar sås till oljepressning.

Rapunzel (diminutivum af rapa, rofva), m., benämning på Klockväxter med knöliga, ätliga rötter. Utomlands tillägges namnet arter af Phyteuma L. (ett för oss främmande slägte), i vårt land två arter af Blåklocka, nemligen Campanula Rapunculus L. och C. rapunculoides L. (se Knylklocka). Alldeles falskt har man fört det till Vårsallaten.

Rast, f., benämnas åtskilliga växter med starka rötter, som hindra plogen (Lat. Rastc bovis, Eng. Rest-harrow och Stay-plough). Vanligast föres namnet till $\mathbf{0 x t u n g o ̈ r t e n , ~ a n n a r s ~ a ̈ f v e n ~ t i l l ~}$ Fodersmäre, stallört m. fl.

Ratanhiarot, f., ett i medicin användt adstringerande medel, som erhålles af den i Peru växande Krameria triandra Rutz o. PAvox.

† Refgräs, Refjagräs, n., växter med refviga stjelkar, t. ex. Medicago falcata 1. (Skåne), Ranunculus répens I. (Hall.), Lycopodium clavatum L. (Smål.) o. annotinum L. (Vesterg.) m.fl.

Reflummer, se Lummer.

Reforms-törel, se Mjölkört.

Reformsört, f. (Reformsgräs, Ringormsgräis), benämning pả väx- ter med skarp mjölksaft, som säges bortfräta reformar, vårtor 0 . s. v. 1) Skelört, allmänt; 2) slägtet Törel, Upl.; 3) Röllika, Dalarne.

Renfana, fo, en på åkerrenar allmän, mångårig höstblomma, beslägtad med Malört, med gula, i en qvast sittande blomhufvud utan strålblommor: Tanacetum vulgare $\mathrm{L}$. (Genom förvexling föres $\mathrm{i}$ Österg. namnet till Röllika.)

İn blåklockan och renfanan

Blomstra ses. Men bort med tranan, Svan' och svalan re'n det bär.

\section{Renlaf, Renmossa, se Laf.}

\section{Renrepe, se Repe.}

Repe, n., grässlägtet Lolium L., med platt ax, småaxen med kanten vända mot axfästet.

Dårrepe, ettårigt, blommorna med borst: $L$. temulentum $\mathrm{L}$. Bekant för sina narkotiska egenskaper.

Linrepe, ettårigt, med omärklig borst: L. Linicola Soxn. Växer bland lin.

Renrepe, mångårigt fodergräs, utan borst: L. perenne $\mathbf{L}$.

Reseda, f., en liten, lätt förbisedd ört, men allmänt odlad för sin vällukt: Reseda odorata I. Vår Svenska Vau är af samma slägte, men luktlös.

Den växt, som tjuste dem, blott en reseda är,

Som obemürkt i vrån der gjuter ut sin anda.

FRANZĖ ' 1: 359 .

Skär och oskuldsfull som Andromeda, Anspråkslös och ljuf som en Reseda.

Rhabarber (= Rha barbarum), m., ett örtslägte tillhörande Slideknäväxterna, skildt från sina närmaste slägtingar Syrorna genom nio ståndare: Rheum I.

Mat-rhabarber, med släta, odelade blad: $R$. Rhaponticum L. En växt af stort värde för köket.

Äkta Rhabarber erhålles från Högasien, ovisst ännu af hvilken art. Den 
under detta namn odlade är R.palmatum L., med flikiga blad. Rhabarberroten är ett i medicin högt värderadt medel.

Ribs (förvridet Risp), m., ett allmänt buskslägte med bär under blomman: Ribes L. Hit höra Vinbär, Måbär, Stickelbär, Krusbär, särskildt upptagna.

Ricin, m., en buskväxt i Orienten, tillhörande Törelväxterna (Ricinus communis L.), af hvilken erhålles Ricinolja.

Riddarsporre, m., ett örtslägte tillhörande Ranunkulaceerna, med findelade blad, oregelbundna, $i$ en sporre utskjutande bla blommor: Delphinium $\mathrm{L}$.

Allmänna eller Vilda Riddarsporren har grenig stjelk, en småfrukt: D. Consolida L. Är åkerfältens prydnad.

Rommerska Riddarsporren har enkel stjelk, tre småfrukter: D. Ajacis L. Odlas som prydnadsväxt. Denna är de äldre författarnes Hyacint, på hvars inre kronblad är tecknadt AIA.

Se, hur lycklig och stolt syns Riddaresporren i blomma,

Ien på de innersta blad dock tecknas

(Efter OvIDII: ett qvidande A.ja.

Ipse suos gemitus foliis inscribit, et AI AI

Flos habet inscriptum. Metam. 10:215.

Rifva, f., en ettårig, sträfbladig ört med små blommor, liknande Ogonblommans, och hvars fullt utvuxna blomfoder har likhet med en gåsfot: Asperugo procumbens L. Dess benämningar Ormöga och Paddfot äro som växtnamn otjenliga. - Man förgäter Rifvan, fast syster till Förgät-mig-ej.

$\div$ Rind, f., Gotl. = Murgrön.

Ringblomma, f. 1) I riksspråket örtslägtet Calendula L., af Hålkblomstriges familj, med brandgula blommor och olikformiga, delvis krökta frukter. 2) I folkspråket tillägges namnet flere växter af samma familj med utdragna strålblommor, t. ex. Gula Krageblomman, Hästfiblan och Hästhofsörten. Blåklett (Blåklint) kallas äfven Blå Ringblomma.

Ur gräset skymtar fram ringblomman och hvitsippan. BELLMAN 4: 76 .

("Ringblomman" kan här ej tydas, om ej med Hästhofsörten.)

Ringborste, $\mathrm{m}$. Liljeblad $=$ Dosta.

Ringdosta, se Dosta.

$\div$ Ringormsgräs, se Reformsört.

Ringormsrot, f., Skåne $=$ Scor zoner-rot. Detta inhemska folkspråksnamn är märkvärdigt för sin lika betydelse med det Italienska Scorzonera och Spanska Escorzonera (af scorzone, ett slags orm) samt det Engelska $V_{i-}$ pergrass.

†Rinka, f., förvridning af Binka (se der).

Ripbär, n., frukten af Fjellmjölonriset. Jfr Fjellbär.

+Ripris, n., Lappl.=Dvergbjörk.

Ripört, f., en liten ört af Nosseväxternas familj, förekommande i fjellripans region: Chamorchis alpina Rror.

Ris, n., kallas i växtnamn mindre buskväxter, såsom Blåbärsris, Lingonris, Moris. Gränsen mellan ris och buske är sväfvande, så att benämningarna Hallonbuske och Hallonris användas utan åtskilnad.

Ris, n., ett ädelt sädesslag från Ostindien, nu allmänt odladt i varmare länder: Oryza sativa L. Af dess frön erhållas Risgryn.

Risets säd, som vill på sanka fält

I början af sin växt bli under vattnet stäldt. OXENSTJERYA 2: 130 .

Riska, f. (från 'Tyskan), en läcker svamp af Mjölkskiflingarnes slägte; med brandgul mjölksaft: Lactarius deliciosus (L.). 
$\div$ Risp, se Ribs.

+Rocka (Eng. Rocket, Lat. Evuca), f., benämnas i Småland fruktknutorna af Åker-rättikan. Äfven Polygonum lapathifolium L. kallas Rockor, i Bleking Ryklor, hvilket troligen är samma ord med olika uttal. - Rocka betyder egentligen $7: a ̊ l$, såsom i Rockentraf.

Rockentraf, m., en ört tillhörande Kålväxterna, med stjelkomfattande blad, hrita blommor och långa, upprättstånde skidor: Turritis glabra $\mathrm{L}$.

† Rockor, f. pl., se Puggerocka och Täpperocka.

\section{Rofklocka = Rapunzel.}

Rofkål, Rotkål, m., auses för en genom odling frambragt förändring af Gotlandsrofvan.

Rofva, f. 1) Egentligen odlade förändringar af kålarter med köttig rot:

Allmän Rofva, med rund rot: Brassica Rapa $\mathrm{L}$.

Gotlandsrofva, äfven Långrofva, Åkerrofva (Gotl.), med tapplik rot: Brassica Napus L. (Namnet Långrofva har af missförstand blifvit öfverfördt till Bunias.)

2) Atskilliga andra växter med köttig rot, såsom Hundrofva, Klockrofva (Rapunzel).

†Rohaltgräs, se Stighåltgräs.

$\div$ Rone, se Roxne.

Ros, f. 1) i vidsträcktare mening en allmän benämning på större, prydliga, merendels mångbladiga, dubbla blommor. Vill man utmärka någon viss art, måste alltid ett epitet tilläggas, såsom Fackelros, Neckros, Stjernros o. s. v. "Rosor och violern. Omqväde.

En yppig ros, som växer vild

Bredvid en fallen Herkulsbild. TEGNER 2: 15. 2) i inskränktare mening buskslägtet Rosa L., dock vanligen endast de odlade dubbla arterna (allmännast Törnros, Trädros), af hvilka man har otali- ga förändringar med egna namn. Jfr Törnros. De vilda Roserna benämnas vanligen Törne, Nyponbuske m. m. "Ingen ros utan törne". Ordspriik.

Ur knoppen sticker rosen ut

Sin friska purpurmun.

STAGNELIUS 2: 165 .

Hur sköna äro rosens späda knop-

Ljúft doftar rosen, stänkt af daggens droppar - -

I rilda rosor, sinnebilder kära

Af hopp och kärlek och min framtids dar!

En krans af er jag vill på hjessan bära. ARNELL 67.

$\div$ Rosenbenved, Rosentry = Try. Obrukliga, öfverflödiga namn.

Rosengissel, m., en särdeles passande benämning, af Franzén gifven àt Cactus (Cereus) flagelliformis L., som vanligen odlas under namnet Paradisorm, hvilket dock är obrukbart såsom växtnamn.

Lik en gissel, full med taggar,

Redan ögat ondt du gör.

Midt bland taggarne till slut

Slår en härlig blomma ut. FRANZĖN 6: 127 .

Rosenkattost, se Kattost. + Rosenkål = Kruskål.

Rosenpil, f., Roslager, m., tvenne i Dalins ordbok upptagna benämningar på Nerium Oleander L., som jag aldrig hört kallas annat än Nerium, hvilket namn ock lämpligast bevaras. Jfr Oleander.

Rosenrot, f., en fjellört, beslägtad med Kärleksörten, men blommorna enkönade, hanblommorna med åtta ståndare: Rhodiola rosea $\mathrm{L}$. "Växer vild i Lapska fjellen, och fyller ofta luften med en behagelig rosenlukt, som roten i detta klimat eger. Den växer väl äfven i våra trädgårdar, men rotens lukt är då långt svagare". RETZIUS 2: 599.

† Rosenträd, n., ett namn som någon gång gifvits àt Alprosen och, enligt Dalin, àt den för oss helt och hållet främmande Convolvulus scoparius L. FIL. 
Rosliug, m., ett med Ljung närförvandt slägte, skildt genom tio ståndare. Allmänna Roslingen växer i träsk och har liffärgade blommor: $A n$ dromeda polifolia L. Se Andromeda. (ㅅ̊̊ ej förvexlas ined Rossling.)

Rosmarin (af Ros marinus), m., en på södra Europas hedar växande halfbuske af Sugeväxternas familj, utmärkt genom sina aromatiska egenskaper: Rosmarinus officinalis $\mathrm{L}$. Rosmarinen uppfyller fälten i södra Europa om nätterna med en doftande vällukt, liksom Sandnäglikan i Skåne.

$\mathrm{Hvi}$ kransar du med rosmarin och

Ej våra fromma larer mer? myrten

STAGNELIUS $1: 484$.

Vild Rosmarin $=$ Sqvattram, på $^{\circ}$ apoteken kallad Rosmarinus silvestris.

Rosmarinvide, se Vide.

Rossljung, Rossling, se Ljung.

Rost, m., små på lefvande växter lörekommande svampar med stoftlikt utseende och vanligast brungul eller rostgul färg: LEcidium PErs. Dessa äro af mångfaldiga slag och erhålla namn efter de växter, på hvilka de förekomma, t. ex. Tallrost, Hveterost, Linrost m. H., som icke synes nödigt att särskildt upptaga. Det är i synnerhet på sädesslagen de äro för landtmannen förderfliga.

För motgångarue strax blef grödan blottad. Af rosten

Friittes dess halm. ADLERBETH 58.

Brandrost (Uredo Pers.) saknar eget omgifvande hylle och är merendels svartbrun.

Penselrost (Roestelia penicillata Fr.). Da den utbryter, förlänges dess hylle till ett rör, som i spetsen upplöses i pensellika flikar. Rönnpenselrosten ( $R$. cornuta Eurr.) är i synnerhet allmän och skadlig för boskapen.

Skålrost (Ecidium) omgifves af ett oegentligt hylle, som regelbundet öppnar sig skålformigt med en stjernlikt tandad mynning. Hit hör den be- ryktade Berberisrosten ( $A$. Berberidis Pers.).

Rotabagge, m., en i Vestergötland it Kålroten gifven benämning, som vunnit Europeisk ryktbarhet och blifvit upptagen i de flesta språk.

Rotper'silja, se Persilja.

Rotting, m., stammen af den rörlika Rottingpalmen, som uppnår flere hundra fots höjd: Calamus Rotang I.

+Roxne, Rone, n., arter af slügtet Fräken: Kärrfräken, skaf-fräken.

† Rump-ull, f., Linné = Snip.

Runarot, se Safjabräken.

Runu, se Rönn.

Ruta, f., se Murruta, Vinruta, Ängsruta.

Ryltåg, se Tåg.

Rylört, f., en ständigt grönskande buske, lik Lingonris, men med vigglika, sâgade blad och rödletta blommor, liknande Vintergrönans: Chimaphila umbellata Nurr. Benämnes äfven Statt upp och gack, emedan deu anses bota för lamhet.

Anm. P̊̊ hvad grund Liljeblad hänfört Rylörten till Lathrcea L., är svårt att inse.

$\div \mathbf{R y m}$, Liljeblads namn på slägtet Erysimum L., är en rent förkastlig förvridning. Detta slägte har ett godt Svenskt namn: Gyllen.

†Rymossa, moss-slïgtet Bryum $\mathrm{L}$.

† Rynkblad, n. = Daggskål.

$\div$ Ryssar, Ryssgubbar, m. pl. = Bunias.

Råg, m., ett allmänt bekant sädesslag: Secale cereale $\mathrm{L}$.

Rågen dammar,

Gulddoft kring sig strör. DAHLGREX 1: 187.

Righblomma, f., en liten ört af Nagelörtslägtet, med små hvita blommor pâ bar stängel: Draba verna $\mathrm{I}$. Blommar mycket tidigt om viren.

Nïr růgblomman står $\mathrm{i}$ flor,

Ãr tid att vårrigẹen gror. Smil. orlspr. 
+ Råggräs = Ängkafle.

+ Råglosta, se Losta.

+Råmjölksgräis, Österg. $=$ Kropp.

Rädisa, f., en afart af Rättikan, med rund rot: Raphanus sativus $\mathrm{L}$.

† Räfblad, n., Österg. = Bläcken. †Räfblomster, n.,Boh. $=$ Stallört.

Råfkaka, f., frö af ett Ostindiskt träd, Strychnos Nux vomica L., som användes dels i medicin, dels till förgiftning af luder för rofdjur.

$\div$ Räfklor, f. pl., en allmän benämning på Getväpling, men alla dylika namn äro så formelt origtiga, att de måste förkastas. ört.

†Räfmjölk, f.=Törel. Jfr Mjölk-

$\div$ Räfpiss, m. = Stinknäfva.

† Räfrumpa,f., Räfsvans, m., ett $i$ alla afseenden förkastligt och tillika obestämdt namn, tillagdt Ängkafle, Åkerfräken, Ledgräs, Kropp, Blåeld, arter af Kungsljus $\mathrm{m}$. fl.

Råfstarr, se Starr.

+ Räftunga, f., Vesterb. = Gullris.

Raittika, f., ett örtslägte bland Kålväxterna, med knutiga, afbristande men ej uppspringande skidor: Raphanus $\mathrm{L}$.

Trädgårdsrättika, med gredelina blommor, köttig rot: $R$. sutivus $\mathrm{L}$.

Åker-rättika, med blekgula, ådriga blommor,-tunn rot, som dock eger rättikesmak: $R$. Raphanistrum $\mathrm{L}$.

Rödarv, m., en liten, vacker ört, tillhörande Hvifveväxterna, med enkla motsatta blad och röda (stundom blå) blommor: Anagallis arvensis L.

Rödbeta, se Beta.

Rödbinka, Rödbo, se Binka.

Rödbok, se Bok.

† Rödbär, n., Gotl. = Smultron.

Rödfikor (Dal.), Rödkolla (Vesterg.), Rödtuppa (Skåne), Rödtusta (Boh.), Rơdvåpling = Rödklöfver.
Rödfloka, f., ett örtslägte bland Umbellaterna, med findelade blad, i början rödletta, sedan hvita blommor och sträfhåriga frukter: Torilis Anthriscus Garel.

Rödglim, se Glim.

Rödklett, se Rlett.

Rödklint, se Klint.

Rödklöfver, se Klöfver.

Rödknåa, fo, en i södra Sverige vanlig benämning på Milda Pilörten (Polygonum Persicaria L.), för dess uppsvälda röda leder. - Huru man genom missförstand af namnets stafning kommit att kalla hela slägtet Polygonum för Näfva, se under detta namn.

Rödkolla, se Rödfikor.

Rödkulla, $f$., ett örtslägte bland Skeplingsväxterna, med lancettlika, naggade blad, rödbruna blommor, vid basen tandade ståndare: Odontites Pers.

Rödlonke, m., en liten på vâta ställen växande ört, lik Lonke, med tydligt blomfoder, men oftast saknande blomkrona, sex ståndare: Peplis Portula $\mathrm{L}$.

Rödlök, se Lök.

Rödmell, se Mell.

Rödmossa, se Hvitmossa.

Rödplister, se Plister.

Rödpyttor, se Pyttor.

$\div$ Rödrot, f., Dal. = Blodrot.

Rödtuppa, Rödtusta, Rödväp* ling, se Rödfikor.

Rödvira, se Vira.

+ Röknäfva, origtigt i st. för Rödknä. Se Rödknäa.

Röksvamp, Röksvampar, en egen familj bland Buksvamparne, hvars inre massa upplöses i ett rykande pulver: Lycoperdinei $\mathrm{F}_{\mathrm{R}}$.

Röllika, f., en allmän ört af Hålkblomstriges familj, med endast fem 
strålblommor, vanligen hvita, sällan rödletta: Achillea Millefolium L. Röllikan är en i medicin högt värderad växt.

Rönu (i folkspråket äfven Runu), f., ett allmänt träd, tillhörande Kärnfruktträden och samslägting med Oxeln, men har parbladigt sammansatta blad och röda, syrliga bär: Sorbus Aucuparia L. Rönnens bär eller drufvor äro för flere foglar en begärlig föda och begagnas derföre af fogelfängare till bete.

Rönndrufvan glöder. TEGAER 3: 36.

Och ifrån höjden en doftande rönn

Räckte mot văgen den ljusgula vippan, Speglade kronan i himmelsblå sjön. DAHLGREN 1: 401.

När jägarn samlar hop de bittra rönnars bär

Att kläda snarans knut, som väntar luftens här. OXENSTJERNA 2: 152 .

Rönnpenselrost, se Rost.

Rör, n., ett grässlägte, närförvandt med Vass (båda skiljas från öfriga genom en hårtofs inuti blommorna), men spädare, med enblommiga småax: $C a-$ lamagrostis Adsss. Af äldre författare kallades jemväl Vassen Rör; äfven Linné förenade dem till ett slägte.
Bergrör, ett styft, sträft, bredbladigt gräs: C. epigejos Roru.

Sandrör, ett styft, gråhvitt gräs med inrullade blad: C. arençia Rотн.

Öfriga arter urskiljas ej af allmänheten. - Jfr Piphven.

\section{Rörflen, Rörflok, Rörfläck,} m., se Flen.

Rörsopp, m., ett artrikt slägtebland Hattsvamparne; lätt skildt genom ett lager af fina rör eller pipor, packade på hattens undre sida, men som kunna utan svårighet söndras från hatten: Boletus Dru. Samtliga rörsoppsarter växa på jorden, äro köttiga, tlera bland dem värderade såsom näringsmedel, dock några giftiga. $\mathrm{Om}$ arterna se Fries, Sveriges ätliga och giftiga svampar.

Rörsvingel, m. (Fluminia arundinacea $\mathrm{Fr}_{\text {.) }}$, se Kase.

† Rörtand, f., ett föga bekant svampslägte: Irpex $\mathrm{F}_{R}$. (numera ej Sistotrema Pers.).

† Rörvass utgår.

Röte, n., rotstockarne af Qvickroten, som uppgräfvas och läggas i fria luften att förtorka. Se Linnés Sk. resa 35, 51.
Sabadillfröô, n., frö af en i Mexico växande art utaf Nysrotslägtet: Veratrum Sabadilla REтz.

† Sabelböna, f., se Böna.

Sabel-lilja, f., ett nytt, men ej förkastligt namn på det utländska slägtet Gladiolus L., förvandt med Svärdsliljan.

+ Sabelărt, se Ärt.

Safflor, m., en så väl för sin nytta som prydlighet odlad ört, tillhörande Tistelväxterna, med taggigt sågade blad och högröda blommor: Carthamus tinctorius L. "Safflor voro blomblad, köpta utifrån, som färgade rosenrödt». Linnés Ö1. resa 34.

Saffran, m., en tidigt om våren blommande lökväxt af Svärdsliljeväxternas familj, hvars blompip utskjuter ur sjelfva löken: Crocus L. Pistillerna af Âkta Saffran (C. sativus L.) lemna den under namnet Saffran bekanta kryddan.

Tmolus dig sänder till gärd den välluktspridande saffran. ADLERBETH 55 . 
Safjabräken, n., Safsabuske, m., den utmärktaste af våra Svenska Bräkenarter, med dubbelt parbladiga blad och fruktklasar i toppen : Osmunda regalis L. - Safjabräkenet tillskrifras i Småland mystiska egenskaper och det anses förläna vishet (se Linnés Sk. resa 40); namnet synes således förvandt med det af Grimm antagna Mrösogötiska safjan, sapere. Ett annat i Småland brukligt namn på denna växt är Rörot eller Rönrot, hvilket, då hvarken till röd eller rönn finnes den aflägsnaste anledning, torde rätteligen vara kunarot, hvari alltså (Isl. $\min$ betyder egentligen hemlighet, vishet) skulle ligga en liknande hänsyftning som i namnet Safjabräken.

Saftskifling, m., en afdelning af Vaxskiflingarnes slägte, med vattenaktig saft: Hygrophorus, subgen. $H y$ grocybe, $\mathrm{I}_{\mathrm{k}}$.

Safver, m., en bekant köksväxt, som vanligen, men origtigt, benämnes Kyndel. Se detta namn.

Sagogryu, n., fås af mergen hos flera Palmarter och Cycadeer, företrädesvis Sagopalmen (Sagus Rumphii WrLL.) och Cycas circinnalis L. i Ostindien och pâ Molúckerna.

Salep, m., ett mycket närande mjöl, som i vatten upplöses till ett gelé; fås af rotknölarne hos åtskilliga Nosserotsyäxter, t. ex. Orchis Morio 1.., Orchis mascula L. och Anacamptis pyramidalis Rror.; den $\mathrm{i}$ handel förekommande erbålles dock-till största delen från Orienten. face - femele

Salepsrot, Salepsört, f., benämning i Svenskan på Anacamptis pyramidalis RxcH. sälg.

† Sall, f., Skåne, enligt Linné

Sallat, m., gemensam benämning på åtskilliga växter, som förtäras rå, t. ex. Krasse, Laktuk m. fl. I äldre tider begagnades för samma ändamål äfven Krasse-sommargyllen och arter af Fetknopp. - Jfr Vårsallat.

Sallats-laktuk, se Laktuk.
Salomons ljusstake, m., en art af Krasseslägtet, med upptill bågformigt böjda grenar, liknande en kandelaber: Lepidium campestre R. Br. Namnet förekommer i Upland.

$\div$ Salomons sigill, n., ett ur apoteksspråket (Sigillum Salomonis) upptaget namn på Rams (Polygonatum Toura.), men utan allmännare spridning.

Salsa, Saltört, f., hafsstrandsväxter, tillhörande Mollaväxterna, med. trinda, köttiga blad utan brodd i spetsen, och med små gröna, i bladvecken gyttrade blommor.

Glatt Saltört, Schoberia maritima c. A. MrX.

Luden Saltört, Kochia hirsuta NoLte.

$\leftarrow$ Salsel, Liljeblad $=$ Sodaört. Utgår.

Salsofi (efter Franskan), f. = Hafrerot. (Detta med flera andra Franska namn, brukliga i förra seklet, äro nu utträngda af rent Svenska.)

Saltarv, m., en på hafsstränder växande ört, tillhörande Narfväxterna, utmärkt genom köttiga, saftfulla, äggrunda blad: Halianthus peploides Fr.

† Saltbläcker, se Bläcken.

† Saltgrås, n., Hels. = sälting.

Saltört, se Salsa.

Salvia, f., ett bekant örtslägte af Sugeväxternas familj, med läppformig krona och endast trå ståndare: Salvia $\mathrm{L}$.

Äkta Salvia, med blommor i ax: S. officinalis $\mathbf{L}$. Odlas för sin vällukt och sitt användande i medicin.

Äng-salvia, med stora blå blommor i krans: S. pratensis L. Vild i Upland.

Sammetsblomma, Sammetsros, f., ett örtslägte bland Blomhålksväxterna, med sammetsludna strål- 
blommor: T'agetes $\mathbf{L}$. Odlas som prydnadsväxter.

En sammetsblomma kiins den huldas arm.

BESKOW 1: 50.

Brun Sammetsblomma, med grenig stjelk: T. patula $\mathrm{L}$.

Gul Sammetsblomma, med merendels enkel stjelk: $T$. erecta $\mathrm{L}$.

$\div$ Sammetshrete, $\mathrm{n} .=\mathrm{Kubbh}$ vete.

+ Sammetspungar, m. pl., enligt Wahlenberg = Fårkummer.

+Sammetsviol, f., en odlad, storblommig förändring af Styfmorsviolen, med nedre blombladen sammetsludna.

Samosört (Samol, Liljeblad) $=$ Punga.

, Sandarak, m., ett slags harts, som erhålles af Callitris quadrivalvis VEXT., ett barrträd i norra Afrika.

Sandborst, m., ett gräs med grå, borstlika blad och smal vippa, växande $\mathrm{i}$ sand: Corynephorus canescens $\mathrm{P}$. BeAuv.

Sandelträ, n., den gula, hårda, aromatiska veden af Sandelträdet: Santalum album $\mathrm{L}$. Ett annat slags Sandelträ erhalles af trädet Pterocarpus santalinus L. Fr.., hvars ved är röd, för öfrigt lik den förstnämnda. Båda träden växa i Ostindien.

Sandgröe, m., en art af slägtet Glyceria R. BRo, växande på hafsstränder:

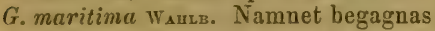
af Liljeblad, men växten räknas numera icke till slägtet Gröe ( $P o a \mathrm{~L}$.).

Sandhafre, $m_{1}=$ Sandrör. - Namnet föres ofta origtigt till Strandrågen, så t. ex. i Linnés Sk. resa 336 ; men i hans Öl. och Gotl. resa 139, 205, föres det rigtigt till Sandröret.

Sandhvita, f., en ört af Korsblomstriges familj, med stjernludna blad, hvita blommor, korta, mångfröiga skidor: Alyssum incanum $\mathbf{I}$.
Saudlök, se Lök.

- Sandmossa utgår alldeles. .

Sandnarf, m., äfven Sandört, f., ett litet slägte bland Narfväxterna, med små, odelade, hvita kronblad: Arenaria $\mathrm{L}$.

Sandnäglika, se Näglika.

$\div$ Sandris, n. = Nagelört, enligt Dalins ordbok. Namnet är mig alldeles obekant, och någon dess tillämplighet på slägtet Nagelört kan ej upptäckas.

Sandrör, se Rör.

Sandstarr, se Starr.

† Sankt Britæ 10̈k, i Vadstenatrakten = Ramslök.

+ Sankt Hans blomster, Sankt Hans ort, Skåne = Hästfibla, men föres derstädes äfven till Kärleksörten, enligt Linnés Sk. resa 251.

† Sapotiljträd, n., Achras Sapota L. Till namnets upptagande i språket finner jag ingen anledning.

- Sappan, n., ett slags Ostindiskt färgträ, som erhålles af Ccesalpinia Sappan L., äfven räknadt till Bresilja.

Saronsblomster, n. 1) Ett örtslägte, af Linné fördt till Näglikeslägtet, men skildt derigenom att det har blommorna i ett hufvud inom ett svepe: Tunica Soop. 2) Saronsnäglika (Dianthus Armeria L.), lik Tunica, men hörande till Näglikeslägtet. - Uttrycket i Psalmboken (394: 5):

Du Sarons blomster sköna!

Du lilja i grön dal!

torde vara källan till namnet, hvilket blifvit tillämpađt på nämnda art Näglika.

Sarsaparill, m., roten af den Sydamerikanska växten Smilax Sarsaparilla $\mathrm{L}_{\circ}$, anvä̉nd i medicin. Såsom surrogat för den samma begagnas rotstocken af Sandstarr, hvilken deraf faitt namnet Svensk Sarsaparill. 
+ Sassafras, m., en Nordamerikansk buske af Lagerfamiljen, använd i medicin: Sassafras officinalis NEES.

+ Satyrört, ett namn, bildadt af det Latinska Satyrium L.; men då detta slägte numera är alldeles upplöst och ingen inhemsk art finnes deraf efter slägtets nyare begränsning, förfaller namnet af sig sjelft.

$\div$ Savoykål, m., en bland de talrika artförändringarna af Kål, hvilkas meddelande tillhör speciella trädgårdsböcker.

$\div$ Seammonium, n., roten af en art Vinda från Orienten, som har häftigt purgerande egenskaper: Convolvulus Scammonia $\mathbf{L}$.

Sehersmin, m., en allmänt odlad buske med hvita, fyrbladiga blommor: Philadelphus coronarius L. Har stark, för de fleste behaglig, men för mig stinkande lnkt. Namnet förvexlas ofta med Jasmin, som hos oss ej växer under bar himmel, hvarföre hit maiste höra Bellmans: Syren, jasminer

Sprida vällukt öfver allt. 2: 109.

$\div$ Scilla, f., se Hafslök.

Scorzoner-rot, f., en från södra Europa härstammande Fibleväxt, som ej sällan odlas hos oss för sina ätliga rötter: Scorzonera hispanica L. Skiljes från sin slägtinge Kornfiblan ( $S$. humilis L.) genom starkare grenighet och mindre ludenhet. Benämningen användes redan af Bromelius, men för S. humilis. Jfr Ringormsrot.

Selleri (Fr. Céleri), n., en Umbellat, nuärbeslägtad med Persilja, men med enkelt parbladiga blad: Apium graveolens L. Odlas för kökets behof; vild i Skåne. Den vilda plantan anses giftig. Jfr Märke.

Ifrån Lofön komma vi

Med grönsaker, selleri. BELLMAN 3:163.

Sempertin, m., en stundom odlad Tistelväxt med stora, hvitfläckiga blad, blomhålken med en dubbel rad af taggar: Silybum marianum Gxnтx. - Genom förvexling har namnet i Skåne öfverförts till Tistelborren, och derefter likaledes i våra Floror.

$\div$ Sempertuppa, f., 'Gestrikl. = Gulhvifva.

$\div$ Semperviv, m. $=$ Taklök m. fl. Namnet tillägges i allmänhet saftfulla växter, som skilda från roten fortfara att växa.

Senap, m., ett örtslägte tillhörande Kålväxterna, lättast skildt genom sina skarpt smakande frön: Sinapis $\mathrm{L}$. Senap är en värderad matkrydda. nEtt senapskorn... när det varder uppväxt, är det störst ibland kryddorn. Watth. 13: 31, 32.

Hvitsenap, med tve-eggade skidor och gula frön: S. alba L.

Svartsenap, med fyrkantiga skidor och svarta frön: S. nigra $\mathrm{L}$.

Akersenap har knöliga skidor med tve-eggad spets: S. arvensis L. Akersenapens frön hafva en besk, oangenäm smak, hvarföre den är oanvändbar som matkrydda. Är ett högst besvärligt åkerogräs.

† Senegarot, f., erhålles af en art Jungfrulin, Polygala Senega I., från Nordamerika.

Senegräs, n., Sener, f. pl. Detta namn tillägges âtskilliga gräs med styfva, sega blad, såsom arter af Rör, af Starr; men i bestämd mening föres det till Enodium cceruleum Pers, skildt från öfriga genom oledadt strå (blott nere vid roten finnes en ledknut).

Sennetsblad, n., ett bekant laxermedel, som erhålles af flern arter Cassia L. från Egypten och Orienten.

Sensitiva, fo, arter af slägtet $M_{i}$ mosa L., hvars småblad om aftnarne, äfvensom när de vidröras, lägga sig. tillsamman: $M$. sensitiva, M. pudica $\mathrm{L}$.

Du varma, känslofulla själ!

Hvad bäst du liknar vet jag väl:

En sensitiva, späd och skär,

Din lefnads blomma är. NYBLOMr 91. 
Seradella, f., en i senare âren införd späd, men myeket gifvande foderväxt af slägtet Klovicka: Ornithopus ebracteatus Ввот.

Serf, Sörf, m., benämning på flere under vatten sänkta växter, men hvilken endast med tillagdt epitet kän användas, t. ex. Hornserf, Hărserf, Nateserf.

Sesam, m., en i Orienten allmänt odlad kryddväxt: Sesamum orientale $\mathbf{L}$.

- Silenört utgår alldeles.

Sileshår, n., ett i kärr växande örtslägte, hvars blad på öfre sidan äro beklädda med långa hår, som i spetsen utsippra en klibbig vätska: Drosera $\mathrm{I}_{\text {. }}$.

Silfver- tillägges flere växter såsom artnamn, t. ex. Silfvergran (se Gran), Silfvermolla (Atriplex rosea L.) $\mathrm{m}$. $\mathrm{H}$.

$\div$ Silfverdyna, f. $=$ Törel, enligt Linnés Sk. resa 272.

Silfrerfingerört, se Fingerört. Silfrerpoppel, se Poppel.

Silfrerträd, n., gemensam benämning på talrika arter af familjen $P_{r}$ teacece Juss., växande på Cap och i Nya Holland, med af hvit ludd silfverskimrande blad. Hit hörer:

Ethiopernas skog, som snöhvit glänser af bomull. ADLERBETH 75 .

Silfrerört, f., en mycket gammal benämning på en art af slägtet Potentilla L. eller Fingerört, afrikande genom parbladiga, på undre sidan vanligen hvitludna blad: P. anserina L. Må ej förblandas med Silfverfingerörten $(P$. argentea $\mathrm{L}$.).

Silke ingår 1) som stamord i flera namn på Snarrefvan, t. ex. Hörsilke, Nässlesilke ; 2) som artnamn i andra benämningar, men Silkesmulbärsträd (hos Dalin) är ett alldeles onödigt och obrukligt namn. - 3) Atskilliga finare Alger benämnas äfven Silke, Vattensilke.
Silkesblomster, n., en art af slägtet Nattiol, med röda blommor: Hesperis matronalis 1. Jfr Eng. Satinflower.

$\div$ Silkesört, fo, upptages af Dalin som namn på den Amerikanska Asclepias syriaca $\mathrm{L}$.

† Silledön, se Sönnerdön.

$\div$ Simp, m., Vesterg. = Senap.

Sinngrön, f., ett ständigt grönskande växtslägte med vachra blå blommor, hvilkas flikar äro liksom vridna: Vinca $\mathrm{L}$.

$A n m$. Detta namn är gemensamt för alla Germaniska språk (hos oss anfördt redan af Franckenius: "Sijgröönn) och betyder den ständigt grönskande. Bör således föredragas det i Bot. utf. $3: 248$ antagna Igrön eller Ivgrön (evig-grön), ehuru âfven detta har godkänd auktoritet och samma betydelse. Alldeles origtig är benämningen Vintergrön.

Sippa, f., namn på allmänt bekanta och firade vårblommor, med enkelt, kronbladslikt blomhylle och enfröiga småfrukter: Anemone L.

Uti bergets klyfta

Sippan, späd och rädd,

Ses sitt hufvud lyfta

Upp ur drifvans bädd.

KELLGREX 2: 45.

När våren kommer, då vakna sippor. SEHLSTEDT 1: 20.

Blåsippa, med foderlikt svepe, blå eller röda blommor: A. Hepatica L.

Hvitsippa, med trenne skaftade svepeblad nedpå stjelken, hvita blommor: A. nemorosa L.

Se Flora, som $\mathrm{i}$ vårens sköte

Är lifvad pi̊ sin bleka biidd

Och redan vid ett älskadt möte

I blå och hvita sippor klädd. GYLLENBORG 1: 184.

Se hvitsippan hur täck hon är, men :ack! hur förgänglig. FIRANZEX 6: 132.

Gulsippas lik den föregående, men stjelken oftast tråblommig och blommorna gula: A. ranunculoides $\mathbf{L}$.

Sittrer, se Zedoaria.

†Själa, f., Själegräs, r.=Skära.

† Sjöblad, n. = Neckblad. 
$\div$ Sjögräs, $n$, en allmän benämning på i vatten växande gräslika växter; i speciell betydelse: Bändling.

Sjönöt, f., ett utmärkt örtslägte, med stora ätliga nötter och med flytande blad, som likna björklöf: Trapa natans L. Sjönötter hafva ännu i förra i̊rhundradet vuxit i Kalmar läns sjöar, men äro nu der utgångna; på senaste tiden hafva de blifvit funna i en sjö i Skåne.

Sjöplommon, n., en vattenväxt, räknad till Algerna, lik plommon: Ulva pruniformis $\mathrm{L}$.

Sjösäf, se Säf.

+Sjöållon, n., frukten af Neckrosen.

† Skabb-blomster, n., Vesterg. $=$ Kabbelök. Kallas, enligt Rietz, äfven Klådblomster.

Skaf-fräken, se Fräken. ken.

Skafgräs, Skafrör = Skaf-frä-

+ Skafvel, n., frukten på Bok. Namnet synes vara alldeles utgånget.

Skalleblomma, f., ett örtslägte bland Skeplingsväxterna, förvandt med Sporreblomman, men har mycket kort sporre och dess fröhus liknar en dödskalle: Antirrhinum L. - En inhemsk art, Akerskalleblomma (A. Orontium L.), har små röda blommor. En mycket storblommig (A. majus L.) odlas; se Lejongap.

Skallergräs, se Höskallra.

†Skallnacke, m., Österg. = Smörblomma. Jfr Munkhufvud.

+ Skarlakansek, f. $=$ Quercus coccifer'a L. En högst misslyckad öfversättning, ty coccus i coccifer a betyder galläpple, icke skarlakan. (Den Tyska benämningen är dock Scharlacheiche. Utg. anm.)

\section{$\div$ Skarlakansgräs, $n_{0}=$ Stink-} syska.

Anm. Äfven här är ingen fråga om skarlakan. - Det kan vara lärorikt nog att se, huru detta namn småningom uppkommit af det Latinska Sclarcea MrLu., en art af Salvia. Franckenius, för att försvenska den Latinska benämningen, skref Skarleya; Tillandz förbättrade detta till Skarlack, och slutligen blef det, äfven hos Retzius, Skarlakansgräs.

Skateblomster, $\mathrm{n} .=$ styfmorsviol. Namnet upptages, såsom varande mycket vanligt.

Skatnäfva, fo, se Kamnäfva (Kam$\operatorname{mar})$.

Skedört, f., öfversättning af Lat. Cochlearic L. Svenska namnet är Skörbjuggsört.

Skelört, f., en mångårig ört bland Valmoväxterna, med gula blommor och gul mjölksaft, enrummiga skidor: Chelidonium majus $\mathrm{L}$. I likhet med Törel kallas den äfven Reformsört, men namnet Svalört tillägges i folkspråket ej denna, utan endast Ficaria.

Skepling, m. = Kovall, Melampyrum L. Antages af Liljeblad som slägtnamn för detta slägte. Skepnad, skepelse i folkspråket motsvarar icke illa det Latinska Per'sonatce, hvarföre

Skeplingsväxter antagits som Svensk benämning på familjen Personatce L., Tråhjertbladsväxter med 4 (sällan 2 eller 5) olika långa ståndare, fästa på den sambladiga, oregelbundna (oftast läppformiga) kronan, och med tvårummigt fröhus.

Skifling, Skifsvamp, m., den talrikaste gruppen bland Hattsvamparne, med tunna skifvor på hattens undre sida : Agaricini $\mathrm{F}_{\mathrm{k} .}$ - Fjällskifling $\mathrm{m}$. fl. särskilda slägten, se FrIEs, Sveriges ätliga och giftiga svampar, och Bot. utfl. 3: 339-344.

† Skillingar, m. pl. (efter Danskan) = Skärf-frö.

$\div$ Skimmel, n. (efter Tyskan) $=$ Mögel.

+ Skocka, Skåcka, f., Jemtland (efter Norskan) = Daggskål. 
† Skogrås, n., gröfre Halfgräs. Se Lappskogräs.

Skogs-, ett af de vanligaste artnamn, t. ex. Skogsapel, -frier, -fräken, -klöfver, -kovall, -laktuk, -lind, -näfva, -säf, -vial, -vinda, -viol m. fl. Se under slägtnamnen.

Skogsfrublomma, f., en vacker, men mycket bräcklig; bladlös ört, tillhörande Nosseväxterna: Epipogium aphyllum Sw.

+ Skogshumle, $m .=1$ ) Pors, se der; 2) Röllika, Dalarne; 3) Brunört, Dalsland, enligt Linnés Vestg. resa 235; 4) Gullklöfver, Dalsland, enligt Linnés Fl. Svec. n. 671. (Hvilken af dessa två sistnämnda, stridiga uppgifter är den rigtiga?)

† Skogslöper, Dalsland = Ekebräken.

† Skogsmysk, m. = Linnésört.

Skolme, m., f.(?), en tångväxt med trind bål och skidlika frukter: Halidrys siliquosa Lrsab.

† Skomakarskägg, n., Söderm. = Kärrfrier.

$\div$ Skorf, Pinskorf, $\mathrm{m} .=1$ ) i Shåne Allmän Snarrefva (Cuscuta); 2) i Småland Spergel (Spergula). Bindsleskorf äfven = Snarrefva, och namnet passar bättre till Cuscuta än till Spergula.

†Skottlufva, f.,Boh.=Blàhallon. Skriftlaf, se Laf.

-Skroftistel, m., Halland= Akermjölkfibla. Jfr Akertistel.

$\div$ Skrubber, Skrubbair, Boh. = Hönsbär.

Skruftolomstrige kallas familjen Boraginea Adsss., 'Tråhjertbladsväxter, med skiftevis sittande, vanligen sträfva blad, före blomningen spiralformigt inrullade blomklasar, sambladig blomkrona och fyra delfrukter ("nöttern).
Hit höra Lungört, Tungört, Ögonblomma $\mathrm{m}$. $\mathrm{fl}$.

Skråp, m., Skräppa, f. Detta namn synes ursprungligen tillhöra de stora, breda bladen af Tussilago enligt Linnés omfång; så i norra Sverige ( $P e$ tasites frigida $\mathrm{F}_{\mathrm{r} .}$ ) och i Norge. Sedan har det blifvit öfverfördt 1) till bladen af Karborre (kallade Thordönsskräppa) och liknande blad, samt 2) till de stora Syre-arterna.

† Skläikon, n., Jemtl.=Kråkbär. Skräppa, se Skråp.

Skräppesyra, se Syra.

+ Skummeslöfsört, f.= Gul Krageblomma.

† Skurgräs, n. = Skaf-fräken.

Skyfall, n., en Alg, växande på torr mark, $\mathrm{i}$ torr väderlek hopskrumpen och nära osynlig, men efter regnväder uppsväld och slemmig och derföre ausedd nedreguad: Nostoc commune $\mathrm{V}$ aucri.

Skyffelkorn, se Korn.

Skålbild, se Skålsvamp.

$\div$ Skål-laf utgår.

Skållost, se Rost.

Skålsvamp' (Skålbild), m., små skål-lika svampar, mycket allmünna: Реziza L.

Skäde, n. = Dårrepe. "De som drucko af öl, brygdt af skädblandadt korn, blefvo liksom fånnge och niistan blindan. Linnés Gotl. resa 223.

$\div$ Skäitte, n. = skaf-fräken.

† Skägghvete, n. = Kubbhvete.

Skågglaf, se Laf.

Skäkteblad, n., en vattenväxt tillhörande Etthjertbladsväxterna, med pil-lika blad och hvit blomruska: $S a$ gittrria sugittifolia L. Namnet upptages redan af vaira äldste författare ("Skäktegräs") och är än i dag bibehallet $\mathrm{i}$ folkspråket, men de äldre be- 
nämningarna Skottgräs, Skyttegräs äro utgångna. Jfr RrETz, Ordb. 614.

† Skälfvegrås, n. = Darrgräs.

† Skälfving, m., Liljeblads benämning på det gelatinösa svampslägtet Tremella (Dirz.).

+ Skälla, f., benämnes på vissa orter Blåklockan. Jfr Bjälla. - Bergskälla, se detta namn.

Skälle, n., är egentligen slösäd, eftersäd vid kastningen; men emedan denna till stor del utgöres af ogräsfrön, har namnet blifvit öfverfördt på dylika växter, t. ex. Åkerkovall (Linnés Fl. Svec. n. 546), Höskallra (Linnés Sk. resa 147 ), Skärf-frö (ders. 177 ) $\mathrm{m}$. fl.

Skära (äfven Själa och Skärda), f., ett slägte bland 'Tistelväxterna, men utan taggar, blomfästet fjälligt. Den enda inhemska arten är Ängskära (Serratula tinctoria $\mathrm{I}_{\text {. }}$ ), en mỵcket värderad färgväxt. - Skärca (af skir) ingår äfven $i$ andra färgväxters namn, sâsom Brunskära och Gulskära, samt i Kardskära (se Kardtistel).

Skärf-frö, n., örtslägtet Thlaspi L., tillhörande Krasseväxterna, med små platta skidor, liknande runda penningar. Àkerskärffröet (T. arvense L.), som är ett svårt ogräs på åkrar, har stark löklukt. Jfr Byggn.B. 8:4.

Skäl-floka, f., ett Umbellatslägte, utmärkt genóm sina jemnbreda, skärlikt krökta blad: Falcaria Rivini Host.

† Skärvass, se Vass.

† Sköldblad, n. = Neckblad.

Skölding, m., Sköldört, f., benämnes af Liljeblad slägtet Tropcoolum ı., som för frukternas angenäma krassesmak allmänt odlas under namn af Indiansk Krasse. Bladen äro runda, sköldlika, blommorna stora, oregelbundna, brandgula hos vår odlade $T$. majus $\mathrm{x}$.

Anm. Namnet' Indiansk Krasse kommer nog att bibehållas, ehuru olämpligt och i systematiska arbeten obrukbart.

\section{Sköldlaf, se Laf.}

Skörbjuggsört, f., ett på hafsstränder växande örtslägte, tillhörande Krasseväxterna, men med tjocka, saftfulla blad och runda skidor: Cochlearia L. Den Äkta Skörbjuggsörten ( $C$. officinalis L.), med oskaftade stjelkblad, är ett berömdt medel mot skörbjugg. - Mindre rigtigt har man öfverfört namnet till slägtet Fetknopp.

+ Skörsilke, n., en at ett mikroskopiskt Algslägte (Diatoma $\mathrm{DEC}_{\mathrm{E}}$ ) gifven benämning, som icke kan komma i fråga att upptagas, äfven om den vore mindre olämplig.

† Slake, m. = Klottång.

† Slanggurka, f., en utländsk, för oss främmande Gurkväxt: Cucumis flexuosus $\mathbf{L}$.

+ Slemhorn, Slemklot, Slemklubba, Slemklänge, Slemknopp, efter Liljeblad anförda af $\mathrm{Da}$ lin, äro samtligen obetydliga namn på ännu obetydligare, tvetydiga växter, hvilka aldrig bort komma i fråga att i en Svensk ordbok upptagas.

Sli, Slima, f., Algslägtet Batrachosper'mum Rоти, bestiende af busklikt greniga, slemmiga trådar.

Slideknä, n., ett örtslägte af mycket olika utseende, hvars underslägten Ormrot, Pilört, Fogelört och Binda särskildt upptagas. Utgör typen för

Slideknäväxter, Tvåhjertbladsväxter, skilda från alla öfriga genom slidor, nedtill omgifvande stjelkens leder inom bladen; blommorna små, ofullkomliga, med ett frö: Polygonere Juss. Hit höra, jemte de under-Slideknä anförda, äfven Syra, Bohvete, Rhabarber $\mathrm{m}$. $\mathrm{fl}$.

\section{Sligefrö, n. = slägfrid.}

Slima, se Sli.

Slinke, n. 1) Slägtet Nitella Aa., trådlika, pipiga, kransgreniga, ledade 
Groddtrådsvärter, ständigt nedsänkta i vatten, lederna encelliga. 2) Atskilliga trådlika,.i hafret växande Alger.

$\div$ Slinklaf utgair alldeles.

Slimnor, f. pl. (Slyngon, Slynnen, n. pl.), i Göta rike den vanliga benämningen på Blåbär. Enligt Linné (Fl. Suec. n. 332) skall i Halland namnet föras äfven till odon, men detta grundar sig troligen på någon förvexling.

Slokbjörk, se Björk.

Slokgräs, $n$., ett vackert grässlägte med tvåblommiga småax, utan borst, de yttre agnskalen af småblommornas längd: Melica L. - Ordet gräs bortfaller vid sammansättning.

Bergslok, m., med sammandragen, ensidig, lutande vippa: M. nutans $\mathbf{L}$.

Grusslok, m., med axlikt sammandragen vippa, håriga agnskal: $M$. ciliata $\mathrm{L}$.

Lundslok, m., med upprätt, grenig vippa, inre blomman felslående: $M$. uniflora RETz.

Slokstarr, se Starr.

Sloktistel, se Tistel.

Slån, f., en allmän buske med tornar, tillhörande Stenfruktträden : Prunus spinosa I. Trukterna, kallade Slånbär eller Stärkebär, äro klotrunda, svarta, med kärf smak. Till samma slägte höra Krikonträd (äfven kalladt Tysk Slån) och Plommonträd.

Slånga, $f .=$ Bändling. Jfr Vattenslinga.

Slånlaf, Slånmossa, se Laf.

Slåsskämpar, se Kämpar.

Slåtterblomster, n., ett namn, icke ntmärkande någon viss växt, utan tillagdt många växter, som blomma vid slattertiden, t. ex. Hvita Visiln, Hästfiblan $\mathrm{m}$. $\mathrm{fl}$.

Slåtterfibla, f., ett allmänt örtslägte, tillhörande Fibleväxterna, med bara blomstänglar, fjälligt blomfäste och på tvären rynkiga frön: Hypocharis L. Blommorna äro gula. Allmänna Slåtterfiblan ( $H$. maculata L.) kallas i Vesterg. Slåttergubbar, i Jemtl. Slåtterkullor. (Äfven Hästfiblan ka]las stundom Slattergubbar.)

\section{Slåttergröe, se Gröe.}

Slägfrid, f.= Gulmåra. Ett mycket gammalt namn, som blifvit öfversatt med Frillogräs. Sedan ordets bemärkelse (frilla) utdött, har man trott att det skulle betyda slagsmål. Se Rietz, Ordbok.

$\div$ Slätt, m., förvridet uttal af Klett.

Slöke, n., en gammal benämning på Qvanne, of Isl. slok, ränna. Detta nu obrukliga namn anser jag lämpligen kunna öfverföras till Pleurospermum austriacum IIofrs., pi hvilken växt det vida bättre passar, ty denna är den enda Umbellat, hvars stjelk utgör en fortgående ränna utan afbrott genom tvärleder. För att häntyda på växtens slägtskap med Libsticka, kan man göra ett tillägg till namnet och kalla den slöke-sticka.

$\div$ Slökestut, m. = strätta.

$\div$ Slökorn, n., de vilda arterna af slägtet Korn (Hordeum L.).

Smile, m., små, ettåriga gräs, förr räknade till slägtet Tåda, men hafva i spetsen tvåklufna agnskal, fastväxta vid frukten: Airopsis Desv. - Namnet Smile tillägges allmänt både i Tyskland och Norge arterna af Aiv' $\mathrm{J}$.

Sminkbär, n.; ettåriga örter af Mollaväxternas familj, hvilkas blomhylle uppsväller och blifver köttigt: Blitum virgatum och capitatum $\mathrm{L}$. Öfriga i senare tider hitförda arter föras i folkspriket till slägtet Mell.

Sminkrot, f., se Horleta.

† Smockbär, n., äldre namn pa Smultron. 
† Smultpåron, n., utgår alldeles.

Smultron, n., ett allmänt kändt örtslägte, hvars bär äro bildade af det uppsvälda fruktfästet: Fragaria L. Jfr Jordbär.

Ur vård af späda blad, som hölja dem för dagen,

$\mathrm{På} \mathrm{böjda} \mathrm{stjelkars} \mathrm{topp} \mathrm{de} \mathrm{låga} \mathrm{smul-}$ tron tagen.

OXENSTJERNA 2: 53 .

Röda smultron mellan blad.

NICANDER 1: 22.

Rödaste smultron i mjölk och vin. BELLMAN 3: 246.

Kom att purpursmultron plocka.

STAGNELIUS 2: 291.

Backsmultron, med foderflikarne tryckta intill frukten: $F$. collina Еввн.

Marksmultron, med foderflikarne utstående, frukten lätt affallande: $F$. vesca $\mathrm{L}$.

Trädgårdssmultron, vanligen kallade Jordgubbar, skiljas från båda de föregående genom större, på ytan gropiga frukter: $F$. elatior Енвн.

Flera utländska arter odlas, men deras namn äro ännu obestämda.

†Smultronbuske, m. Namnet är olämpligt (rättare Mjölonbuske) och äfven öfverflödigt dels derföre, att växten ej finnes hos oss, dels emedan den i skrift vanligen kallas Arbus, Arbuser: Arbutus Unedo L.

† Smultronklöfrer, m., en mindre bekant art af Klöfver: Trifolium fragiferum L.-

Småborre, m., en mångårig ört, tillhörande Brumväxterna, med gula, $i$ en lång klase sittande blommor, frukterna under blomman med i spetsen haklikt krökta taggar: Agrimonia Eupatoria L. Småborrens frukter hänga sig fast vid kläderna, liksom Karborrar.

+ Småknoppar, m. pl., en ettårig art af slägtet Fetknopp: Sedum annuum $\mathbf{L}$.

Smålummer, m., en med Lummer närförvandt växt, med taggigt tandade blad: Selaginella spinulosa Az. Bravx.
† Smälla, f., Smällor, pl. (Smätjon Dal.), växter med uppblăsta blomfoder, hvilka, hastigt krossade, spricka med en smäll. Egentligast Tarald.

† Smällon, n., Skåne = Backsmultron.

Småre, m., ett fornnordiskt, ännu brukligt namn på Klöfverväxter, men som i allmänhet öfvergått till uttalet smör; tillägges nu slägtet Medicago L. (äfven kalladt Kosmör), hvilket skiljer sig från Klöfver genom bågformigt böjda eller ock spiralvridna ärtbaljor.

Blåsmäre, med blå blommor, spiralvridna ärtbaljor, $i$ äldre tider odlad under namn af Luzern: $M$. sativa $\mathrm{L}$.

Fodersmäre, äfven Svensk Smäre, med gula blommor, bågformigt böjda ärtbaljor: $M$. falcata $\mathrm{L}$.

Smör- ingår i en mängd växtnamn, äfven till betecknande af mjukare frukter, t. ex. Smörnypon, Smörpäron m. fl.

Smörblomma, f., den allmännaste arten af Fibleväxterna, med enkel, mjölkrik stängel, som slutar med den smörgula blomman: Taraxacum officinale $\mathrm{W}_{\mathrm{EB}}$. (I Dalsland tillägges namnet äfven Leontodon autumnalis $\mathrm{L}$.) Smörblomman blommar hela våren och sommaren och upphör sist om hösten.

En smörblomma, ännu qvar

Utaf sommarns fagra dar,

Emot månen blygsamt drar

Upp sitt gullgula standar.

DAHLGREN 1: 79 .

Anm. Bland denna växts mångfaldiga namn är Smörblomma det allmännast spridda och i skriftspråket mest brukliga. Det är äfven det mest karakteristiska: det mjölkrika örtståndet liksom öfvergår till smör i blomman. Af dess öfriga namn är Skallnacke mest betecknande. Flera, såsom Lejontand (osvenskt), Kopiss, Svin: ros, Maskros 0. S. V., äro rent af förkastliga och utan tillämpning på växten.

\section{Smörblomster, Smörfånga,} Smörört (se Linnés Sk. resa 240) äro mycket obestämda namn, som för de gula blommornas skull tilläggas åtskilliga Ranunkulaceer, såsom 1) Kabbe- 
löken, synuerligast i Dalarne; 2) flera arter af slägtet Solöga; 3) Gulsippan. - Äfven Smörblomman kallas Smörblomster.

$\div$ Smörbollar, Smo̊rbullar, m. pl. = Bulleblomster.

$\div$ Smörbär, n., Jemtl.=Hönsbär.

Smörnypon, se Nyponbuske.

$\div$ Smörpalm, f., en palmart, som är hos oss så obekant, att den ej kan ega Svenskt namn: Cocos butyracea L. Fin.

- Smörträd, n., ett tropiskt träd med läderartade blad, hvars frukt innehåller ett smörlikt ämne: Pentadesma R. Br. P. butyraica växer i Sierra Leona. - Namnet Smörträd är af Dalin fördt till den näst föregående, Cocos butyracea.

Snara, f., se Snärjegräs.

Snarbindel, se Snarvinda.

Snarmåra, se Måra.

Snar-refva, f., ett trådlikt, bladlöst, på andra växter växande örtslägte: Cuscuta L. Utom Allmänna Snarrefvan (C. major Dec.) är i synnerhet den på lin värande Lin-snarrefvan ( $C . E p i$ linum WEIнE) ett skadligt ogräs, och under senare åren har till oss inkommit Klöfver-snarrefvan (C. Trifolii BAs.), förderflig för klöfverfälten.

Snarvinda (origtigt Siarbinda), se Vinda. - Med Snarbindel i $\mathrm{Sv}_{\circ} \mathrm{Lag}$, Byggn.B. $8: 4$, förstås väl både Àkerbinda och Akervinda.

Snigelmossa, se Mossa.

†Suip, m., Gestr. en liten art af slägtet Ängdun: Eriophorum alpinum L.

+ Snoddergräs, n., Ångerm. = Åkerbinda.

$\div$ Snoktistel, m., Skåne $=$ Bittermjölke.

$\div$ Snokört, f., Retzius = Blåeld.

$\div$ Snotter, pl., Vesterb.=Hjortron.
Snufreblomma, $f_{0}=$ Skogsfrublomma. Vanligen egnad nskogssnufvan'” (skogsrå).

Snufveläder, n., en packad massa af svampars vegetativa system, som förekommer i gamla träd, synnerligast i Bok. Kallades af Tode Xylostroma giganteum.

†Snuggbär, n., Elfd.= Smuitron.

Snyltrot, f., en bladlös, på andra växters rötter växande ört, med gulbruna, läpplika blommor, liknande Skeplingsväxterna, men fröhuset är enrummigt: Orobanche L.

† Snytterbär, n., i Hels: olika. uttal af Snotter. (Enligt Linné är i nämnda landskap Snytterbär namn på Smultron. Utg. anm.)

Snärjegräs, Snårpegrås, n., allmännaste benämningen på Snarmåran. I Dalarne kallas Allmänna Snarrefvan Gult Snärjegräs.

Snöbollsträd, n. = 0lvonbusken med endast gallblommor.

Snödroppe, m., en lökväxt, beslägtad med Narcissen, med en hvit 乞 hängande blomma på hvarje stängel, de tre inre kalkbladen urnupna och grönfläckiga: Galanthus nivalis I. Snödroppen blommar tidigast af alla örter, under islossningen.

Snöhvita, f., ett lämpligare namn på Draba verna $\mathrm{L}$. än Răgblomma.

Snöklocka, f., en art af slägtet Klocklilja (lilja bortfaller i sammansättningar), närbeslägtad med Snödroppen, men större, upprätt, alla kalkbladen likformiga, i spetsen grönfläckiga: Leucojum vernum L. Blommar något senare än Snödroppen.

Snölaf, se Laf.

Snö-ört, f., Öland = Röllika.

Socker- tillägges flere värter som artnamn, t. ex. Sockerlönn, -tång ( $L a$ minaria saccharina LAsrßx.); men mest 
som artförändringsnamn, t. ex. Sockerböna,-toppskål,-melon, -potates m. $\mathrm{fl}$.

+Sockerkist, m., ett Amerikanskt trädslag, närmande sig Mahogny.

Sockerpalm, f., en palmart i Guinea, af hvilken palmsocker erhalles: Arenga saccharifera LABILL.

Sockerrot, f., en för sina välsmakande rötter odlad art af slägtet Märke, hvarföre den rätteligen bör kallas Sockermärke: Sium Sisarum L.

Sockerrör, n., ett högväxt gräs i de varmare länderna, af hvars söta saft socker beredes: Saccharum officinarum. $\mathrm{L}$.

\section{Sockerärt, se Ärt.}

Sodaört, f., en med Saltört beslägtad art af Mollaväxterna, lätt skild från 'alla genom sina taggigt tillspetsade blad: Salsola Kali L. Sodaörten växer på hafsstränder.

Sodomsåpple, n., ett på ytan glänsande, men inuti med asklik mașsa fyld frukt, växande kring Röda hafvet: Solanum sodomceum $\mathbf{L}$.

Dock ofta bildning, konst Qch smak

Ett sodomsäpple var.

ATTERBOM 1: 162. ört.

$\div$ Sodöda, f., Wahlenberg $=$ Flen-

Sojaböna, f., ett till Ärtväxterna hörande örtslägte i China och på Japan, af hvars bonor Soja beredes: Soja hispida Мовмен.

+Sokrasse, m., Wahlenberg $=$ Gatkrasse.

Solan, m., det artrika slägtet Solanum $\mathrm{L}$. Må hända blir det nödvändigt att behålla detta Latinska namn såsom gemensamt slägtnamn, emedan intet af de inhemska är dertill lämpligt.

Solblomma, f., se Solros. "Solblomman, snart sagdt det största blomster i naturen, fröjdade sig nu högeligen mest vid alla boudehyddor, som för 100 år sedan endast kunde trifvas vid de Kongligas palais och i de präktigaste trädgårdarn. Linnés Sk. resa 433 .
† Solbär, n., Skåne (se Linnés Sh. resa 240) och Halland = Svarta Vinbär.

† Soldagg, f. = Sileshår.

† Solfjäderpalm, f., en palmart med bladen solfjäderformiga : Corypha umbraculifera $\mathbf{L}$. Som produkter af detta träd icke komma till oss, bör namnet på sin höjd i ett bihang till ordboken upptagas.

†Solgrås, n., Wahlenberg = Flugsporreblomma.

† Sollvifva, f., Boh. (Linné) $=$ Knyl-solöga.

Solros, f., en ståtlig, ettârig ört af Hålkblomstriges familj, med talrika strålblommor, hvarföre den af Franckenius lämpligast benämndes Solkrona. Af Linné kallad Solblomma (Helianthus L.), se der. - Jfr Аtтerbon 1: 63.

Solsicka (af Lat. solsequia), f., ett gemensamt namn på (gula) Blomhålksväxter, som vrida sig efter solen, nemligen Ringblomman, Solrosen, Hästfiblan, Gula Krageblomman. Vill man skilja den sistnämnda såsom eget slägte, torde namnet lämpligast fastställas för denna, emedan dess "alla blomster vända sig efter solen färdigare än någon annan solblomman. Linnés Sk. resa 251.

†Solskärmsmossa, se Bullmossa.

+Solvisa, Solviser, f., Boh. (Wahlenberg) = Knyl-solöga.

Solvända, f., små halfbuskar med talrika fria stăndare och treskaligt fröhus: Helianthemum Tours.

Solöga, n., ett artrikt slägte af $\mathrm{Ra}$ nunkulaceernas familj, med fria foderoch kronblad, de senare hafvande honungsgrop vid basen, samt med talrika, i ett hufrud samlade småfrukter: $R a$ nunculus $\mathbf{L}$.

Allmänt Solöga, med glatta småfrukter, släta blomskaft: $R$. acris $\mathbf{L}$. 
Knyl-solöga, med frukter såsom det föregående, men refflade blomskaft, lökformig rot: $R$. bulbosus $\mathrm{L}$.

Refvigt Solöga, likt det näst föregående, men med krypande grenskott: R. repens $\mathrm{L}$.

Ảker-solöga, ettårigt, med taggiga småfrukter: R. arvensis $\mathrm{L}$.

(Åmöja och Ältgräs äro särskildt upptagna.)

\section{Somalla, Somilla, f., Söderm. $=$ Brudbröd.}

Sommar-, tillagdt växtnamn, utmärker 1) ettåriga artförändringar, såsom Sommarråg, -hvete, -raps; 2) tidigt mognande frukter, såsom Sommaräpplen, -päron, -nypon.

Sommargyllen, n.,ett slägte bland Kålväxterna, med tveeggadt-fyrkantiga skidor och lrrformiga blad: Barbarea R. Bk.

Allmänt Sommargyllen har bittert besk smak: B. vulgaris R. BR.

Krasse-sommargyllen har angenäm krassesmak: $B$. precoox R. Br. Odlades fordom till sallat under namn af Vinterkrasse.

Sommarhyll, se Hyll.

Sommarnypon, se Nyponbuske.

† Sonke, af Liljeblad bildadt namn på slägtet Sonchus , $\mathbf{\text { . }}$; förkastligt.

Sopmossa, f., namn på större mossor, som användas till viskor, synnerligast Björnmossa.

Sopp, m., den äldre och ännu i vissa landsorter ranliga benämningen på jordsvampar (trädsvampar kallas i allmänhet Ticka). I Dalarne benämnas Skifsvamparne Skurusopp och Rörsoppsarterna Mjölksopp.

Soppegräs, $\mathrm{n}_{\mathrm{.}}=$ Flotagräs. Se Linnés Sk. resa 398.

† Sorgskräpp, f., Vesterb., se Guckusko.

Sostagg, se Stagg.
Sot, Sotax, Sotbrand, se Brand. Sotmossa, se Mossa.

+ Spadklubba, svampslägtet Spathularia PErs. Utgår alldeles.

† Spansk ryttare, m., Blek. en art Nyckelblomster: Orchis mascula L.

Spanskt rör = Rotting.

Sparflins, se Lins.

+ Sparrgräs, n., Wahlenberg = Igelknopp.

Sparris, m., en bekant matväxt, tillhörande Liljeväxterna, med hårfina, bladlika smågrenar och röda bär: Asparagus officinalis $\mathrm{I}$. Den vilda Sparrisen, som förekommer på södra Sveriges hafskuster, är icke ätlig.

Sparrisärt, $\mathrm{f}_{\mathrm{o}}=$ Klöfverärt.

+ Sparilosta, $f_{.}=$Axlosta.

+ Spelbom, m., Gotl. = Benved. Namnet är ett förvridet uttal af Tysk. Spillbaum.

Spelt, m., ett sällan odladt sädesslag af Hreteslägtet, med tvärhuggna agnskal: Triticum Spelta i.

Spenat, $m$., en allmänt odlad köksväxt af Mollafamiljen : Spinacia oleracea L. "Spinat... är ibland de helsosammaste grönsaker och kan väl torkas till vinterfödan. LILJEBLAd. - NyZeeländsk Spenat, Tetragonia expansa Arr., tillhör familjen Ficoidere Juss.

Spenört, f., en stâtlig Umbellat med dubbelt trebladigt delade blad, breda, hjertlika bladflikar och hvita blomflockar, fyravingade frön: Laserpitium latifolium L. Spenörten är.lundarnes prydnad.

Spergel, m., ettåriga örter af Narfväxternas familj, med knutigt ledade stjelkar, trinda, saftfulla blad, hvita blommor, fem pistiller: Spergula L. Åkerspergeln (S. arvensis L.) är på en gång ett godt foder och ett pinsamt ogräs ("Pin-skorf»). 
Spergelklöfverärt, se Klöfverärt.

Spetsgroblad, se Groblad.

Spetshagtorn, se Hagtorn.

$\div$ Spetsmossa utgår.

Spikblad, n., en liten, krypande Umbellat med sköldlika blad och enkla blomflockar, växande på fuktiga ställen: Bydrocotyle vulgaris $\mathrm{L}$.

Spikklubba, fo, en med Bolmörten förvandt räxt med stora, vackra hvita blommor och fyrskaliga (taggiga) fröhus : Datura Stramonium L. Spikklubban är giftig, men användes i medicin.

Spikvalmo, se Valmo.

$\div$ Spillrofva, $f .=$ Långrofva.

Spindelsvamp, m., ett talrikt slägte bland Skifsvamparne, medespindelväfslikt hylle och mer eller mindre ockra-färgade sporer: Cortinarius $\mathrm{F}_{\mathrm{R}}$. Bland Spindelsvamparne finnas inga ätliga.

Spindelört, f., en liten mångårig ört med smala, jemnbreda blad och små fyrklufna blommor, fästa på bladskaften: Thesium alpinum L. Hos oss är Spindelörten ej någon fjellväxt, utan tillhör Småländska höglandet.

Spiralört, f., en sydeuropeisk, under vatten väsande ört, hvars honblommors skaft äro trådlika och spiralvridna: Vallisneria spiralis $\mathrm{x}$. Örten har af misstag uppgifvits som Svensk, men odlas stundom $i$ aqvarier.

Spirea, f., utländska buskväxter, tillhörande (jemte Mjödörten och Brudbrötet) slägtet Spircea L. Bland flera arter, de flesta hvitblommiga, förtjenar särskildt upptagas:

Röd Spirea (S. salicifolia L.), allmänt odlad och flerstädes förvildad.

Spirkål utgår.

Spiskummil, m., benämnes den vanliga Kummilen till skilnad från den äkta. sydeuropeiska Kumminen.
† Spokter (Spökter)? - en från Göteborgstrakten uppgifven benämning på vanliga Hundkazen.

Sporreblomma, f., ett i södra Europa artrikt slägte bland Skeplingsväxterna, utmärkt af blommans sporré: Linaria Tours. Den mest bekanta arten är:

Flugsporreblomma (L. vulgaris Wrux.), med större, gula blommor i en klase, allmänt känd under namn af Flugblomster (se der). ? velvoter

$\div$ Sprakved, m. = Brakved.

$\div$ Spricklaf, Sprickling, utgå alldeles.

Springkorn, n., en vild ört, beslägtad med Balsamin, med gula blommor: Impatiens Noli tangere L. Då det mogna Springkornet vidröres, springa fröhusets skal elåstiskt upp och kringsprida frön.

\section{Spritärt, se Ärt.}

Sprängört, f., en i vatten växande Umbellat med dubbelt parbladigt delade blad, lancettlika bladflikar och små, nästan klotrunda frukter: Cicuta viro$s a$ L. Af äldre författare kallas den odört (se denna). Sprängörten är den giftigaste af våra inhemska örter, i synnerhet rotstocken, som utlakar en gul saft; den uppgifves förgifta sjelfva vattnet för boskapen, som deraf dricker.

† Spurry, m., Retzius = Spergel. Spåmanstistel, $\mathrm{m} .=$ Stjerntistel. Sqvaller, Sqvallerkål, se Qvaller.

Sqvattram, m., Sqväckra, f., en i skogskärr växande buske af Ljungfamiljen; har på bladens undre sida rostfärgad ludd och i grenarnes toppar hvita blomflockar: Ledum palustre L.. De mest ödsliga skogskärren upplifvas af blommande Sqvattram. Sqväckra har en mycket stark lukt och narkotiska egenskaper. 
$\div$ Sqvätta, $f:=$ strätta. Namnet härledes af sqvät, ty de ihåliga stjelkarne användas af barn till sprutor. derot.

† Sqråttlök, m., Dalarne $=$ Vän-

†Stadd, m. Svårligen skulle någon ana, att detta namn härléder sig från Lat. Statice. Liljeblad kallar så både Statice (se Mar-risp) och Armeria (se Trift).

+ Staduflur, f., ̊̊ngerm. = Höstfibla. (Namnet uttydes solstandsblomma.)

† Stadun, n., Alg, tillhörande slägtet Oscillatoria $\mathrm{v}_{\text {AUCB. }}$.

† Staf, m., benämnes af Liljeblad slägtet Frier.

Staffansfrö, n., en utländsk art af slägtet Riddarsporre, använd i medicin : Delphinium Staphysagria $\mathbf{L}$.

Stagg, m., ett styft, stickande gräs med borstlika blad och ensidigt ax: Nardus stricta L. Wahlenberg: Sostagg. "Stagg gör lien slö och ger magert hön. Ordspreik.

Stallört, f., örter eller halfbuskar af Ärtfamiljen, bladen med trenne småblad, röda blommor: Ononis L. Bland de talrika namnen är detta äldst och har bästa auktoritet. Det afser arternas stinkande lukt.

Stinkstallört, med ettårig stjelk, utan taggar: O. hircina JAcQ.

Âkerstallört, äldre taggig, med öfvervintrande stjelk: $O$. arvensis $\mathrm{L}$.

\section{Starkpeppar, se Peppar.}

Starr, m., ett slägte bland Halfgräsen, med han- och honblommor på samma stand: Carex L. Af detta slägte finnas i Skandinavien omkring hundra arter, bland hvilka de flesta fătt Svenska namn sig tillagda i rent botaniska arbeten, såsom Linnés Fl. Svec. och Liljeblads Flora; men att upptaga alla dessa synes mig så mycket mera öfverflödigt, som de icke ingått $\mathrm{i}$ allmänna språkbruket och endast af botanister ex professo komma att aitskiljas.

Backstarr, se nedan vid Vårstarr. Blåsestarr, ett storväxt gräs med uppblåsta frukter, hvilket, jemte andra större arter, lemnar Lappskogräset: C. vesicaria L. Växer i kärr.

Blåstarr, äfven en högväxt art, med skilda han- och honax, men endast tvenne märken: C. acuta L. Växer på åbräddar och lemnar bättre foder än de öfriga arterna.

Gråstarr, en mindre art, med hvitaktiga ax, han- och honblommor i samma småax: C: canescens $\mathrm{L}$. Utgör till päsentlig del höet på kärrängar.

Hafsstarr, den utmärktaste i slägtet, blomfjällen med långa borster: $C$. maritima Yürs. Endast i Bohusläns och Göteborgs skärgård.

Knagglestarr, ettlågväxt gräs, men ådrager sig uppmärksamhet genom sin ljusgröna färg och sina knaggliga småax: C. Alava L. Växer i kärr.

Räfstarr, en storväxt art, med sammansatt, brunt ax, han-och honblommor i samma ax: $C$. vulpina $\mathrm{I}$. Växer på fuktiga ängar.

Sandstarr, lik den föregående, men mindre, utmärkt genom sina flere famnar långa, krypande rotstockar: $C$. arenaria $\mathrm{L}$. nSandstarren... växte under sanden, med några famnars långa krypande rötter, uppsättandes merendels emellan hvart qvarters spatium en liten stjelk och blad, liksom den hade varit planterad efter snören. Linnés Öl. res̊ 139. - Växer endast i flygsand och är ypperlig till dess dämpande.

Slokstarr, en stor art, med flera skilda både han- och honax, de senare hängande: C. Pseudocyperus L. Vid stränder.

Tufstarr, med ett hanax, flera hon$a x$, två märken, lättast skild genom de ljusgröna tufvor den bildar pa fuktiga ängar: $C$. ccespitosa $\mathrm{L}$. Se Linnés Sk. resa 241. - Blommar tidigt och är då lågväxt, men förlänges sedermera. 
Vårstarr (C. procox JAcQ.) och Backstarr (C. ericetorum Pouz.), tvenne smärre, på torrare ställen växande arter, blommande tidigt om våren, ined lifligt gröna blad.

$\div$ Steckelgräs, Steckgräs, n. $=$ Stålört. Föres vanligen till Gentiana Amarella L., men innefattar äfven $G$. campestris $\mathrm{L}$. fräken.

†Stehjok, Dalarne $=$ Fräken, Dy$\checkmark$ Stenbryt, m. $=$ Bergspring.

Stenbräcka, f., flera arter af slägtet Saxifraga L., växande i fjellen, företrädesvis S. oppositifolia L. Se Bräcka.

Stenbräken, n., ett slägte bland Bräkenväxterna, mera spädt och vekt än Ormbunkslägtet (Aspidium $\mathrm{Sw}_{\text {. }}$ ), med ensidigt fruktplättarnes svepe: Cystopteris BerRi:

Stenbär, n. $=$ Stenhallon.

Stenek = Jernek.

Stenfruktträd, n., en växtfamilj med talrika på fodret fästa ståndare och köttiga frukter, som innesluta en stenhård kärne: Drupacece L. Hit höra Hägg, Körs, Mandel, Persika, Slån m. fl.

Stenfrö, n., slägtet Lithospermum L., sträfhåriga örter, tillhörande Skrufblomstriges familj, med hvita blommor och mycket hårda frön. Jfr Perlgräs.

+ Stengräs, n., Medelp. (Flengräs, Vesterb.) = Röllika.

Stenhallon, n., en ört af Hallon'slägtet, med krypande stjelkar, hvita blommor och rö́da bär: Rubus saxatilis $\mathbf{L}$.

Stenmossa, f., allmän benämning för Lafvar, som växa på sten; vanligen hänföres namnet till Parmelia saxatilis Aсr. Se Letlaf.

Stenmurkla, se Murkla.
† Stenpoley = Dosta. Tillhör ej Svenska språket, utan har upptagits ur Tyska kräuterbücher.

+ Stenpäron, n., frukten af det vilda Päronträdet, äfvensom en sämre sort odlade Päron. Vilda Päron.

Stensötá, f., en i bergspringor växande art af Bräkenväxterna, med enkelt parbladigt inskurna blad och bara (ej fjällbetäckta) fruktplättar på bladens undre sida: Polypodium vulgare $\mathrm{L}$.

+ Stenvårta utgår.

$\div$ Stenört, f. = 1) i Upland Kors: ört; 2) i Skåne Bitter-fetknopp, enligt Linnés Sk. resa 240.

$\div$ Stickelblomma, f., Boh. =Fältstålört. Jfr Steckelgräs.

Stickelbärsbuske, m., en art af slägtet Ribs, skild från öfriga genom sina taggiga grenar: Ribes Uva crispa 1. Krusbär är en förändring deraf.

När stickelbuskens bär bland sårande försvar

I mognadsstunden än har växtens grönska qvar. OXENSTJERNA $2: 54$.

† Stiftssvamp utgår alldeles.

+ Stighåltgräs, n., Vesterb. = Linnésört. (Rohaltgräs är olika uttal deraf.)

Stillfrö, n., ett obestämdt namn, som tillägges frön af flera olika arter tillhörande de Korsblomstrige växterna, t. ex. Rockentraf, Fältkrasse, Vägsenap $\mathrm{m}$. $\mathrm{fl}$.

† Stingsel, m., Dal. = Tistel.

+Stingskallar, m. pl., Dal. = Åkertistel.

Stinkmell, se Mell.

Stinknäfva, se Näfva.

+ Stinknässla, f. $=$ stinksyska. Stinkstallört, se stallört.

Stinksvamp, m., en aslikt stinkande svamp med nätådrig mössa, i början täckt med ett svartgrönt slem, och fo- 
ten nedtill omgifven af en slemfyld säck: Phallus impudicus L. Jfr Trollägg.

\section{Stinksyska, se Syska.}

$\div$ Stjelkborre, m.= Kransborre.

Stjernanis, m.; småfrukterna af en i China växande buske, Illicium anisatum L., hvilka i lukt, smak och egenskaper öfverensstämma med Anis. Användas i medicin.

Stjernblomma, f., ett örtslägte bland Narfväxterna, skildt från öfriga genom djupt tvåklufna kronblad: Stellaria L. Till detta slägte hör äfven Våtarv, men den är så allmänt känd under detta namn, att det måste särskildt upptagas.

$A n m$. Man har benämnt äfven de utländska arterna af slägtet Aster för Stjernblomma, men de bibehålla bäst sitt utländska namn, utom Aster chinensis L., som kallas Stjernros.

+Stjernhyacint, $\mathrm{m} .=$ Blåstjerna. Tillhör ej Hyacintslägtet.

Stjernlök, m., lökväxter, tillhörande Liljeväxterna, med hvita, stjernlika blommor: Ornithogalum L. I vanligt tal bortfaller lök vid sammansättning.

Aftonstjerna, f., med i klase sittande, nedhängande blommor: 0 . nutans $\mathrm{L}$.

Morgonstjerna, f., med uppstigande, jemnhöga blommor: 0 . umbellatum $\mathrm{L}$.

\section{Stjernmossa, se Mossa.}

Stjernros, f,, en utmärkt vacker prydnadsväxt, som odlas i talrika förändringar, af Linné räknad till slägtet Aster, men nu bildande ett eget slägte: Callistephus chinensis NEES. (Namnet Stjernros har föga lämpligt tillagts Dufkullan, och förekommer ej i folkspråket.)

Stjerntistel, m., ett utmärkt slägte bland Tistelväxterna, med halmfärgade strålblommor, som utbreda sig $\mathrm{i}$ klar, men sammandragas i kulen väderlek: Carlina L.

Stjeruvädd, se vädd. † Stjernört, f., se Stjernblomma.

Stockros, f. 1) Den ursprungliga och inhemska är slägtet Lavatera $\mathrm{I}_{\text {., }}$ tillhörande Kattostväxterna, skildt genom stora blommor och fria småfrukter: L. thuringiaca L. (I systematiskt afseende föras till detta slägte rättast Rosen- och Desmekattosten.) 2) I trädgårdsspråket föres namnet äfven till en storblommig art af slägtet Alcea, A. rosea $\mathrm{L}$.

Stofferblomma, f, en odlad, ett- $v$ årig växt, tillhörande de Skrufblomstriges familj, med platta blå blommor med strål-lika tänder i bottnen: Borago. officinalis $\mathbf{L}$.

Stolt Henrik (Bonus Henricus), m., ett främmande namn på Mjölkroten, hvilket likväl, enligt Linnés Sk. resa 112 , skall hafva ingått i folkspråket. Kan endast som en kuriositet upptagas.

Storax, m., ett välluktande harts, som erhålles af Styrax officinalis L. från Levanten.

† Storhufvud, n., Skåne, 'en art af Knoppört: Centaurea Scabiosa L. (Stor Knoppört).

\section{Storknäbb, m. = Näfva.}

Stormliatt, m., ett örtslägte af $\mathrm{Ra}$ nunkelfamiljen; öfre blombladet hjelmlikt hvälfdt, inneslutande tvenne skaftade honungshus: Aconitum L. Se Lusfloka och Munkskalle.

Men tillåt ej din krans, hvars färger menlöst skiftas;

Af stormhattsblommans prakt och tibasten förgiftas. OXENSTJERNA 2: 122 .

$\div$ Strandblomster, n., örter växande på stränder, såsom Trift (Boh.), Fackelros (Smål.) m. fl.

Straudgråbo, se Gråbo. 
$\div$ Strandhafre, m., se Sandrör.

Strandkil, m. 1) en inhemsk art af slägtet Aster, med blå strålblommor: A. Tripolium L.; 2) Hvit Nysrot.

Strandklo, f., en på våta ställen växande ört af Sugeväxterna, med blomkransar i bladvecken; nästan regelbundet fyrklufna blommor och två ståndare: Lycopus europæeus 1 .

Strandklöfverärt, se Klöfverärt.

Strandkrypa, f., Strandling (Liljeblad), m., en liten på hafsstränderna krypande ört, lik Rödarv, men utan blomfoder: Glaux mavitima I.

Strandkål, m., en frodig, på hafsstränder växande ört af Korsblomstriges familj, med stora, tjocka, isgrå blad och hvita blommor: Crambe maritima L. Folket berättade, att en borgarehustru i Marstrand hade hemtat sådan kål, kokat och gifvit den àt soldaterna, som spisat hos henne, i stället för Blåkål, hvilka alla blifvit fjollige, när de ätit af samma rätt; men då officerarne undersökte derom, funno de värdinnan lika tokig med gästernan. Linnés Vestg. resa 189.

Strandlilja, f., ett på gränsen mellan Liljor och Tågväxter stående örtslägte, med gula blommor och ludna ståndarsträngar: Narthecium ossifragum (L.). Har fâtt sitt vetenskapliga namn af en gammal sägen, att genom örtens förtärande benen hos boskapen skulle skörna och sönderbrista. Hit förde Linné Ilagräs, men detta namn har en helt annan hänsyftning. Se Ilagräs.

Strandling, se Strandkrypa.

† Strandportlak, m. = Saltarv.

Strandpryl(Hartman), m., en liten ört, förvandt med Groblad, men bladen syl-lika, stängeln enblommig och fröhuset med ett frö: Littorella lacustris L.

Strandråg, m., ett mångårigt, med Råg förvandt grässlägte, växande i flygsand, med krypande rotstock och hoprullade, styfra blad: Elymus arenarius
L. Kallas af sjöfarande Elm eller Helm (af Elymus).

Anm. Till följd af yttre likhet och gemensam växtplats förvexlas detta gräs till namnet med Sandröret. Benämningen Elm, Sandelm tillhör uppenbart förevarande växt; till Sandrör åter höra namnen Sandhafre, Margxäs, Marhalm.

$\div$ Strandrör, $\mathrm{n}_{\mathrm{.}}=$ Vass.

Strandsticka, f., en på hafsstränder växande Umbellat med dubbelt trefingradt delade blad, beslägtad med Libsticka, men har fria frön : Haloscias scoticum $\mathrm{F}_{\mathrm{R}}$.

Strandsvingel, se svingel.

Strandsälting, se Sälting.

Strandärenpris, se Ärenpris.

Strandärter, f. pl., Linné $=$ Hafsvial.

† Struss : (af Tysk. Strauch), m., Skåne = Röd Kornell.

Strutbunke, m., Boh.= Foderbräken. Namnet är karakteristiskt, ty detta Bräkenslägte växer i strutlika bunkar (tufvor), liksom Ormbunkarne.

+ Strål-laf utgår.

Sträfse, n., ett $\mathrm{i}$ vatten helt och hållet nedsänkt växtslägte, liknande Fräken, men spädare, oftast fintaggigt och med alldeles olika fröredning (små nötter): Chara $L$. Sträfset thar en obehaglig lukt, som liknar svafvel-lefver... $\mathrm{Påmanga}$ ställen har man hufrudsakligen denna örten att tacka för torfgrafvarnas återväxt». RETziUs $1: 158$.

Strätta, f., en stor Umbellat, förr förenad med Qvanne till ett slägte, och skild derifrån nästan endast genom det vid frögömmet fasträxta fröet: Angelica silvestris $\mathrm{L}$. Namnet tillägges äfven Sium L.

Ströppel, Ströpple, n., en mycket sprida benämning på Dyfräken.

$\div$ Stubbmossa, ett förkastligt. namn.

$\div$ Studenter, Studentnäglika Borstnäglika. 
Stut ingår i några Norrländska växtnamn, såsom Björnstut (Heracle$u m$ L.), Myrstat och Slökestut (dessa båda för Angelica L.). Ordets härkomst är oviss, men som ifrågavarande växters stjelkar hafva ihåliga leder, liknande tutor, är härledningen af tuta, med omslags- $s$, ej osannolik. Benämningen Tjuton för Angelica, hvilken plägar af barn användas till hvisselpipor, synes dock häntyda på tjuta. Abbedissan Hildegard har Stutgrass, ett namn som man ej lyckats tyda.

Styfmorsviol, se Viol.

+ Stynggräs, n. = Stålört.

Ståltrådslaf, se Laf.

Stålört, f., ett utmärkt örtslägte, tillhörande Bitterväxterna, med motsatta blad, blå blommor och enrummigt fröhus: Gentiana L. Arterna af Stålört hafva bitter smak, men i hög grad toniska egenskaper, hvilka liksom stålsätta organismen.

Allmän Stålört, Fält-stålört,blomkronorna fyrklufna, med fransade fjäll kring svalget: $G$. campestris $\mathrm{L}$.

Klock-stålört, blommorna stora, klocklika, utan fjäll i pipöppningen: G. Pneumonanthe $\mathrm{L}$.

Äng-stålört, Bitter Stålört, lik Fältstålörten, men blomkronorna femklufna: G. Amarella L.

Ädla eller Norska Stålörten, se Baggsöta.

†Ståndpes, Ståndpers, m., Dalsl. m. fl. st. = Nosserot.

Stånds, m., Boh., en art af slägtet Boört: Senecio Jacobcea $\mathrm{x}$.

Stäggan, fo, en stinkande art af Mell: Chenopodium Vulvaria L.

Stäkra, f., ett gammalt, allmänt bekant namn på en växt, som skall vara dödande för hästar; men livilken växt dermed menas, har, såsom i afseende på Ilagräset, varit mycket ovisst. Linné hänförde namnet först, enligt uppgift i Norrland, till Alopecuris geniculatus L. Detta var dock alltför orimligt, hvarföre han i sin Gotländska resa (s. 298) förde namnet till Alisma, hvilken ock af alla våra.äldre författare och än i dag på vissa orter antages vara Stäkra. Men sedermera i sin Vestgöta resa (s.47) säger han sig hafva lärt känna den äkta Stäkran, nemligen Phellandrium, en Umbellat med upprepadt delade blad och nästan klotrunda frukter, hvilken vore ett starkt gift för hästar. Det är ock denna som nu allmänt kallas Stäkra (i Kalmar län Kaxstäkra). Under Linnés Skånska resa inträffade likväl ett nytt uppslag i saken. I beskrifningen öfver denna resa (s. 182-185) omtalar han, hurusom hästar i Malmö åto Stäkra (Phellandrium) i största ymnighet utan att deraf lida något men, hvarföre sjelfva växten 'måste frikünnas från giftig verkan, hvilken deremot af Linné tillskrefs en derpå sig uppehållande insekt, Curculio paraplecticus. Denne torde dock äfven befinnas oskyldig. I min tanke är Cicuta (Sprängörten) den rätta, ursprungliga Stäkran; det finnes dock intet skäl att nu ändra växtens faststälda namn: Enanthe Phellandrium J/AMs.

+ Stämgräs, n., Ångerm. = Vänderot.

+ Stärkebär, n., den mycket sammandragande frukten af Slån (någon gång kallad Stärkebärsbuske).

† Störböna, f., arter af Böna ( $P h a-$ seolus $\mathrm{L}_{\mathrm{o}}$ ), som vinda sig omkring en uppsatt stör.

Sudare, Sultråd, m., ett slägte. bland Tångväxterna, liknande en grof tråd: Chorda Filum (L.).

Suga, f., Sugeråxter, m. pl., en allmänt känd benämning på växtfamiljen Labiatce Juss. (Verticillatce L.), med ledade stjelkar, motsatta blad, blommorna skenbart i krans uti bladvecken 
(sällan i ax i toppen), läppformig blomkrona med två längre och två kortare ståndare, fyra småfrukter. Namnet är mycket gammalt; redan abbedissan Hildegard omtalar en art under namn af Bienen-suga (Lamium album L.). Barn pläga suga honungssaft ur blommans pip, liksom ur vissa Trifolia; deraf namnet.

\section{Sultråd, se sudare.}

Sumak, m., ett garf- och färgämne, som erhålles af åtskilliga arter utaf Nordamerikanska växtslägtet Rhus, specielt $R$. Coriaria L.

Surapel, se Apel.

† Surklöfver, m. = Harsyra.

Surkullor, se Kullor.

Suroxel, se 0xel.

Surtorn, m., en taggig buske med gula, i klase sittande blommor, sex kronblad och sex ståndare: Berberis vulgaris $\mathrm{L}$.

Sutt, m., en art af Groblad, med jemnbreda, köttiga blad, växande på hafsstränder och utgörande en väsentlig del af ${ }^{-}$det berömda sältingsbetet: Plantagó maritima L: nDen nordvestre Juten tror sig icke fägna sina gäster väl, om han jcke bland flere rätter har stufrad Sutt». Retzius 2: 523 .

+Svalblomster, n.= Majhvifva.

Svallojörk, se Björk.

Srallmossa, se Mossa.

Svalting, m., en mångårig vattenväxt med grenig, utbredd blomvippa, sex småfrukter och blad liknande Groblad: Alismá Plantago L. En annan art, Liten Svalting, har lancettlika blad och enkel blomflock: $A$. ranunculoides $\mathrm{L}$.

Svalört, f., en samtidigt med svalornas ankomst blommande ört, genom mångbladig blomkrona skild från Solöga, till hvilket slägte den räknades af Linné: Ficaria ranunculoides Rorn.
Svalörtens rotknölar likna hvetekorn, och blottade af regnskurar hafva de ansetts för nedregnad säd.

Anm. Både denna och Skelörten heta på Grekiska Chelidonium, d. T. s. Svalört. I Svenska folkspråket är det endast $F i$ caria som kallas Svalört, och Chelidonium blommar hos oss minst en månad senare än svalans ankomst.

Svamp, m., den artrikaste klassen i hela växtriket, tillhörande Groddtrådsväxterna,' saknande den gröna färgen, som mer eller mindre tillkommer andra växter. Svamparne fördelas i följande familjer: Hattsvampar, Disksvampar, Kärnsvampar, Mögelsvampar och Rostsvampar. "Sramparne äro ett ströfvande pack, som röfva allt hvad de finna lemnadt sedan Flora gått i sitt vintertält emot hösten». LINNE, Del. nat. 14.

Sramp i hus, se Träfrätare.

+ Svampgryn utgår alldeles.

Svart-al, se Brake.

Svart-andorn, se Andorn.

Srarthufvud, n., de 'ännu icke blommande, svarta blomhufvuden af Tuf-ängdunet.

Svarthö, n., en med Höskallran förvandt fjellväxt, som under torkning svartnar: Bartsia alpinn L. (Sådant eger ej rum med Backtimjan, hvilken origtigt blifvit kallad Svarthö.)

Svartkummin, m., frön af en i södra Europa växande art utaf slägtet Nigella: N. sativa L.

Svartpeppar, se Peppar.

Svartpoppel, se Poppel. ört.

+Svartrot, f., Wahlenberg $=$ Vall-

Svartsenap, se Senap.

Sremmel, m. (af svimma), Smål. = Dårrepe.

Svickra (flexion af Sqvattram), f., Smål. = Rosling.

+ Svinblomster, n. = Kornfibla.

+ Svinborst, $\mathrm{m}_{\text {. }}=$ Stagg. 
† Svinbröd, n., se Brudbröd.

$\div$ Svinbär, $\mathrm{n}_{9}=$ Hönsbär.

Svingel (Svindel, Svimbel hos äldre förf.), m., af Linné förd till slägtet Festuca L., såsom nu är allmänt antaget. (I folkspråket benämnes egentligen Råglostan Svingel, hvilket är samma ord som Svemmel, Lolium temulentum I.) Slägtet Svingel skiljes från Gröeslägtet genom från kronskalens spets utgående agnborst; Lostaslägtet åter är skildt genom borst utgående nedom skalens spets. Allmännare kända arter äro:

Fårsvingel, liten, tufvig, med borstlika blad: $F$. ovina $\mathrm{L}$. Yppersta fårbete.

Strandsvingel, ett högväxt, rörlikt gräs med lutande vippa, bredare blad och småax än nästföljandes : $F$. littorea $\mathrm{W}_{\mathrm{G}}$.

Ängsvingel, lik den föregående, men mindre: $F$. pratensis Huos. Allmän på ängar.

$A n m$. Öfriga anförda Svingelarter,nemligen Axsvingel, Jrannasvingel och Svinsvingel, utgå alldeles, såsom endast i systematiskt intresse tillkomna; men hvilket befunnits origtigt.

Svingel-losta, f., benämnes slägtet Schedonorus P. BEAUv., som är en medelform emellan Svingel och Losta. En art deraf, Fodersvingellosta ( $S$. inerm. P. BEAUV.), är ett af de yppersta fodergräs.

Srinknyler = Knylsyska. Bör kanske upptagas.

$\div$ Svinkrässla, f. $=$ Brudbröd.

$\div$ Svinmandlar, m. pl. $=$ Brudbröd.

Svinmell, se Mell.

Sviumolla, se Molla.

$\div$ Srinros, $\mathrm{f}_{\mathrm{o}}=$ Smörblomma.

$\div$ Svinrot, f. $=1$ ) Liten Ormrot;

2) Kornfibla.

$\div$ Svinsvingel, m. = Mannagräs.
+ Svinsyra, f. = Kråksyra.

† Svintistel, m. = Mjölkfibla.

Sviskon, n., den torkade frukten af en artförändring utaf Plommon, hvars kärnar lossna från fruktköttet.

$\div$ Svålon, n., Rosl. = 0don.

†Svärdgrås, n., Nerike; Vesterb. = Igelknopp.

Svärdslilja, f., ett liljelikt örtslägte med svärdlika blad, prydliga kalkar ofran frukten, tre kalkblad nedböjda: Iris L.

Du växer bland oss lik en svärdslilja opp.

TEGN'ÉR 3: 143.

Gul Svärdslilja (I. Pseudacorus L.), allmän $\mathrm{i}$ åar 0. s. v.

Blå Svärdslilja (I. sibirica L.),'med smalare blad, mindre, blä-blommor.

Af detta slägte odlas dessutom talrika arter.

Sykomor, m., en art af Fikonträd, växande i Orienten: Ficus Sycomorus L. ( $\mathrm{P} \cong$ hvad grund Retzius hänför namnet till Tyska Lönnen, är mig obekant.)

† Sylfrö, n., Sylknapp, m., små mikroskopiska svampar, som ej böra upptagas.

Sylört, f., en mycket liteñ, sällan mer än tumshög ört, liknande Rågblomman, men med syl-lika blad: Subularia aquatica L. Växer på stränder.

Syra, f., ett artrikt örtslägte med grön, sexbladig kalk i tvenne kransar, sex ståndare: Rumex 1. Fördelas i

1) Egentliga Syror, med enkönade blommor och mindre styf växt.

Kråksyra, mycket spenslig, med han- och honblommor på skilda stånd: $R$. Acetosella L. Kallas äfven Bergsyra.

Ängsyra, med han- och honblommor på samma stånd: $R$. Acetosa L. Auvändes som spenat, men har en behagligare, syrlig smak. 
2) Tjerp-eller Skräppesyror, med tvåkönade blommor, styfva stjelkar.

Hafssyra, kalkbladen med långa syl-lika tänder: $R$. maritimus $\mathrm{L}$.

Hästsyra, kalkbladen utan gryn, rotbladen bredt hjertlika: $R$. Hippolapathum $\mathrm{Fr}_{\mathrm{R}}$.

Skräppesyra, lik den föregående, men med lancettlika, vagiga blad: $R$. domesticus $\mathrm{H}_{\mathrm{AR} x \mathrm{rr}}$. Det är endast denna art, som i Småland kallas Skräppa, hvilket namn af Linné fördes till den vida sällsyntare Krussyran ( $R$. crispus L.), som har gryniga kalkblad.

Vattensyra, med nedtill afsmalnande rotblad, gryniga kalkblad: $R$. Hydrolapathum Hops. Denna är den enda art, som växer i vatten, och hvilken i alla Linnés resor kallas Rumex aquaticus.

Syren, m., en allmänt odlad buske från sydöstra Europa och Persien, med hjertlika blad, stora blomklasar, två ståndare: Syringa vulgaris L. Mindre allmänt odlade äro Persiska och Chinesiska Syrenen.

Syrenernas rödblåa tofsar för vinden

Lätt vagga i trädgården neder och opp.

Syrsältá, f., Syrsälting, m., Liljeblad $=$ Harsyra.

Syska (diminutiv af $S u g a$ ), f., örtslägtet Stachys L., tillhörande Sugeväxterna och från Humlesugan lättast skildt genom de bladlika blomskärmarne.

Stinksyska, med hjertlika, skaftade blad: S. silvatica L.

Knylsyska, med oskaftade, smalare blad och knöliga rötter: $S$. arvensis $\mathbf{L}$.

Syssla, f. 1) Örtslägtet Cephalanthera Rror., tillhörande Nosseväxterna, med krypande rotstock, bladig stjelk och upprätta frukter. Namnet är troligen ett olika uttal af Zymbel, hvarmed slägtet förr blifvit förenadt. 2) Benäm- ningen tillägges i Kalmar län de större arterna af slägtet Blåklocka.

\section{Sågtăng, se Tång.}

Såpnåglika, f., en mångårig ört af Näglikefamiljen, med bredare, lancettlika blad och två pistiller: Saponaria officinalis $\mathbf{L}$.

+ Såptråd, n., ett träd i Sydamerika, hvars fruktkärnar användas som såpa: Sapindus Saponaria L. Då hvarken trädet eller dess bruk är kändt i Sverige, ser jag icke hvarföre namnet skall upptagas.

Såpört, f., ett med Såpnäglikan närförvandt slägte, men med smala, jemnbreda blad, smärre blommor: Gypsophila L. (Den i stället för såpa mest använda arten, $G$. Struthium L., tillhör södra Europa.)

Sårläka, f., en Umbellat med handflikiga rotblad, hufvudlika blomflockar och taggiga frukter: Sanicula europae $\mathrm{L}$.

Säf, f., ett större slägte bland Halfgräsen, med flera rundade, knippris gyttrade småax och tvåkönade blommor: Scirpus L. (Arterna med ett enda ax hafva sjelfständiga namn.) Utan artnamn menas med Säf alltid Sjösäfven.

Alltför svag är sấfvens strid mot stormen. KELLGREN $2: 170$.

Sucka, som vinden i säf suckar då hösten är när! MALMSTRÖM 4.

"Den brister ej, som likt säfven sig böjern. Ordspråk, emedan säfven anses för symbol af eftergifvenhet, undfallenhet.

Hafs-säf, med hrass-kantad, bladig stjelk, allmän på hafsstränder: S. maritimus L.

Sjösäf, med trind, bladlös stjelk: S. lacustris L. Det är denna som allmänt är känd under namn af Säf; men i södra Sverige benämnas, efter Danskan, de bladlösa Tågarterna äfven Säf. 
Skogs-säf, med trubbkantig stjelk, mycket yfvig och bladig blomvippa: S. silvaticus $\mathbf{L}$.

Säfferot, f., en Umbellat med fårad stjelk, dubbelt parbladigt delade blad, gyttrade blomflockar och håriga frön: Libanotis montana Ax. Säfferoten, tuggad, befordrar salivens afsöndring; deraf namnet (Lågtysk. sever, Högtysk. seifer, spott, dregel).

† Säfjablomma, f. $=$ Blomvass.

Säfstarr, m., ett litet Halfgrässlägte, midt emellan Säf och Starr: Kobresia WrLLD. Tillhör endast högre fjelltrakter.

Säfrenbom (efter Tyskan), m., en art af Enslägtet, växande i södra Europa: Juniperus Sabina I. I motsats mot vår inhemska, milda En är Säfvenbomen giftig.

\section{† Säld, Sälle $=$ Sälg.}

Sälg, f., ett allmänt trädslag af Pilslägtet, med på undre sidan ludna blad och blommande före löfvens utslående: Salix caprea L. Sälgen växer på torrare mark än öfriga pilarter. "Intet träd i Stierige mognar tidigaren. Linnés Sk. resa 67 . Sälgen är vackrast under blomningen en klar vårdag; dess gullgula hängen omsvärmas då af tusentals bin och andra insekter.

\section{Sållefock, se Fock.}

$\div$ Sälta, f., Boh.=Allmän Knappsäf, Eleocharis palustris R. Br. I Roslagen kallas denna för Sülting, men alldeles origtigt. - Jfr Knappsäf.

Sälting, m., örtslägtet Triglochin L., gräslika växter med trinda blad, smala ax, sex ståndare och sammanväxta småfrukter.
Kärrsälting, med trind, trerummig frukt: $T$. palustre $\mathrm{L}$. Växer i kärr.

Strandsälting, med aflång, sexrummig frukt: T. maritimum L. Växer på hafsstränder, lemnande yppersta bete för hornboskapen. ört.

† Sätgrås, n., Såtört, f. = Tät-

Söl, m., större hafs-alger, egentligast slägtet Rhodymenia Grzv.

† Sömntorn, m., benämnes en skägglik utväxt på Nyponbusken, förorsakad af insektsting.

† Sönnerdön eller Silledön, m., en löjlig förvridning af Grek. Chelidonium. Skåne.

Söt är ett vanligt epitet till afarter med söt smak, såsom Sötbräken (Stensöta), Sötmandel, Sötpotates, Sötäpple m. $\mathrm{fl}$.

Sötblomster, Sötkullor, Söttuppor, benämningar på Kamillblomman, som jemte Röllikan har de talrikaste namn i Svenska språket. Jfr Sötört.

Söte, Sötrot, f., Norska benämningen på slägtet Gentiana ı., ehuru dess artér företrädesvis utmärka sig genom sin beskhet. Se Baggsöta.

Sötgräs, n., ett tvåårigt, välluktande gräs med slak, hängande vippa och enblommiga småax: Cinna pendula Tris. (På slägtet Molinia Somrarr eller slägtet Enodium Gıשv. har detta namn ingen tillämplighet.)

† Sötört, f., ytterligare ett namn på Kamillblomman, men enligt Linné, Sk. resa 270 , föres det rättare till Gulmåran. 
Tagg-ginst, se Ginst.

$\div$ Taggpuke, m., ett alldeles förgätet och obrukligt namn på Stallörten.

Taggsvamp, m., ett artrikt slägte bland Hattsvamparne, med syl-lika taggar på hattens undre sida: Hydnum $\mathrm{L}$. Inga Taggsvampar äro giftiga, men många trähårda och derföre icke ätliga.

Taklök, m., ett slägte bland Fetbladsväxterna, med breda, vid basen löklikt hopade blad: Sempervivum tectorum L. Jfr Huslök. (Namnet har alldeles origtigt blifvit tillagdt Sedum Telephium L. och i Vexiö Ajuga pyramidalis $\mathrm{L}$., för hvilken senare Wahlenberg uppgifvit den mindre lämpliga benämningen Takgran.)

† Talgtråd, n., benämnes Croton sebiferum L., af hvars frön kokas ett slags talg.' Som hvarken växten eller dess produkt är känd i Sverige, vet jag icke hvarföre namnet bör upptagas.

Tall, f., betecknar allmänt i Svea rikes språk Furen, men $i$ Göta rikes allmogespråk är benämningen antingen okänd eller ock tillagd Granen (till hvilken den föres äfven af Tillandz). Jag skulle anse lämpligast att antaga Tall såsom gemensamt namn på Fur och Gran. Ved af båda träden kallas ock ofta tallved.

Norden är så kall...

Högt i hvita snön

Står den höga tall,

Alltid frisk och grön. LING 1:50.

I brokigt skimmer tallen återstrålar

Från rimbeklädda grenar månens ljus.

Silfvergrå stå bergets tallar,

STAGNELIUS 2: 547 .

Snö på minsta gren och barr.

DAHLGREN $2: 4$.

Tallört, f., en helt gul, svampaktig, bladlös, men fjällbetäckt ört med lutande blomklase: Monotropa Hypopitys $\mathrm{L}$. Växer mest på tallrötter.
Tamarisk, $m$., en buskväxt i södra Europa och Orienten, hvaraf en i Arabien växande art utsvettas ett slags manna: Tamarix mannifer'a Енгехв.

Tamariskens bark utsvettas den ädlaste ambra. ADLERBETH 40.

Anm. Linné förde till detta slägte äfven Klådriset, hvarföre denna buske i Dalins ordbok benämnes Tamarisk.

+Tandgräs, $\mathrm{n} .=1$ ) Upl. Knavel; 2) Skåne Törel.

Tandrot (olämpligt Tandört), f., en ört af Korsblomstriges familj, med en tandlika, hvita fjäll bärande rotstock, parbladiga blad och liffärgade blommor: Dentaria bulbifer'a L. Af små lökar i bladvecken är det Latinska artnamnet hemtadt.

Tapioka, f., en sorts gryn, som erhållas af Manihot utilissima Pour, hvilken allmänt odlas i det tropiska Amerika. Grynen förekomma äfven hos oss i handel. Tapioka-plantan har färsk en skarp, mycket giftig mjölksaft, men sedan den blifvit urlakad lemnar den ett i hög grad närande födoämne.

Tapsau, m., ett gammalt, förgätét namn på Spenörten, upptaget af Wahlenberg. Månne det någonsin tillhört Svenska språket?

\section{- Tara, se Tjerp.}

- Tarald, m., arter af slägtet Glim, med mycket uppblåsta blomfoder: Silene inflata Ss. och maritima Wrrs.' Benämningen tillhör Gotland.

Anm. Namnets härledning är oviss; man har gissat, att det eger Arabiskt ursprung, men sannolikare är det Tyskans. Tarant, ehuru detta tillägges en annan växt med uppblåst blomkrona, Gentiana Pneumonanthe $\mathrm{L}$.

Tare, Boh. = Bändling. Namnet är märkvärdigt, emedan dylika växter, enligt Dioscorides (i första årh. e. Kr.), af Kelterna i Gallien kallades Taruk (เavgov:). 
Taskört, f., Taskegräs, n., en allmän ört, liknande Krasse, lätt skild genom sina hjertlika skidor: Capsella Bursa pastoris IED.

- Tax, efter Lat. Taxus = Idegran.

Tazett, f., en art Narciss med flerblommig stängel och hvita blommor: Narcissus Tazetta L.

Tazetten, som ett rum uti din krans begär.

OXENSTJERYA 2: 28.

Tekträd, n., ett resligt löfträd i Ostindien, som användes till skeppsbyggnad: Tectona grandis $\mathrm{L}$.

Terpentin, m., ett harts, som utflyter af àtskilliga barrträd samt af arter tillhörande slägtet Terebinthus Мовмсн. Man har mångfaldiga slag af Terpentin, bland hvilka torde här vara tillräckligt att anföra :

Cyprisk Terpentin, som erhålles af Pistacia Terebinthus och P.vera L.

Svensk Terpentin, af tall och gran. Ungersk Terpentin, af Pinus Cembra $\mathrm{L}$.

Venetiansk Terpentin, af Larix europiea DEc.

Dessutom fås Terpentin af flera Amerikanska tallar.

Thebuske, m. 1) Chinesiskt The erhålles af en i China inhemsk buske, närmast beslägtad med Camellia: Thea chinensis $\mathrm{L}$. Deraf förekomma i handel flera sorter, såsom Grönt The, Svart The, Thebohe o. s. v. 2) Paraguai-The fas af en vida skild buske, Ilex paraguariensis. Sx. Hru., och brukas allmänt i Amerika, vanligen under namn af Matte.

†Theros, f., en odlad art Törnros: Rosa indica $\mathrm{L}$.

The-årenpris, se Ärenpris.

†Thordönsskräppa, f., Skåne= Karborre. Jfr Skråp.

+Thorsnässla, f., Söderm. = Allmän Flenört, Scrophularia nodosa L.
Tibast, rätteligen Tirsbast, m., en tidigt om våren på bar qvist blommande buske med tre sammansittande röda blommor: Daphne Mezereum L. Namnet förbråkas i uttal nästan i oändlighet: Tirbust, Tjurbast, Tisbast, Tistbast, Taisbast, Tifvelbast, Tived, Tivedsbast $\mathrm{m}$. fl. Afser egentligen barken och veden, liksom det motsvarande Tyska Seidelbast, fordom Ziubast, Zidelbast. Jfr Bot. utfl. 2: 85. - Växtens benämning Källerhals, äfven gemensam med Tyskan, afser egentligen bären.

Ticka, f,, ett talrikt slägte bland Hattsvamparne, nästan uteslutande växande på träd, med fina porer på undre sidan, hvilka ej kunna skiljas från hatten: Polyporus $\mathrm{F}_{\mathrm{R}}$. Linné förenade detta slägte med Rörsoppslägtet och öfverförde derföre origtigt namnet äfven till det sistnämnda. Bland slägtets många synnerligen utmärkta arter förtjena upptagas:

Björkticka, allmän på björk, hatten vidhäftad med en på öfre sidan snedt sittande puckel: $P$. betulinus $\mathrm{F}_{\mathrm{F}}$. Begagnas till kork, nåldynor, rakstriglar $\mathrm{m}$. m.

Fjällticka, en stor, på löfträd växande art med gul, brunfjällig hatt och snedt sittande, nedtill svart fot: $P$. squamosus $\mathrm{F}_{\mathrm{R}}$.

Fnöskticka, se Fnösksvamp.

Fårticka, en på jorden växande art, hvit, köttig, ätlig och välsmakande: $P$. ovinus $\mathrm{F}_{\mathrm{R}}$.

Jetteticka, en af de största svampar i verlden, växande på rötterna af gamla stubbar, med rödbrun, köttig, men seg hatt: $P$. giganteus $\mathrm{F}_{\mathrm{r}}$.

Svafvelgul Ticka växer i tufvior (klumpar) på gamla trädstammar, höggul, med köttig hatt: $P$. sulfureus $\mathrm{F}_{\mathrm{R}}$.

Tufvig Ticka, Tufticka, växer i tufvor på marken, med tegelfärgad. hatt: $P$. confluens $\mathrm{F}_{\text {r. }}$ Ätlig. 
Yppig Ticka växer i stora tufror vid trädrötter, med talrika, of fvan grå hattar: $P$. frondosus $\mathrm{F}_{\mathrm{R}}$. Ätlig.

Tidlösa, f., sista höstblomma, uppskjutande alldeles naken ur en underjordisk lök, med gredelina blommor: Colchicum autumnale $\mathrm{L}$. Tidlösans blad utbildas först följande vår, då äfven frukten mognar.

Timjan, m., en allmänt bekant kökskrydda af Sugeväxternas familj: Thymus vulgaris L. Vi ega af detta slägte äfven tvenne inhemska arter:

Backtimjan, med refvigt krypande, öfverallt finluden stjelk, smala blad: T. Serpyllum L. (Jfr Svarthö.)

Ängtimjan, med uppstigande, endast i kanterna finluden stjelk, äggrunda blad: T. Chamoedrys $\mathrm{F}_{\mathrm{r}}$.

† Timmermossa, Timmsmossa utgå alldeles.

Timotej, m., ett i nyare tid inkommet namn på Ängskampe, uppkalladt efter Timothy Hanson från Newyork, som i England införde odlingen af detta fodergräs.

$\checkmark$ Tina, f., Gotl. = snarmåra.

Tistel, Tistle, m., benämnas flere taggiga, stickande växter; men egentligen tillkommer namnet slägtet $\mathrm{Car}$ duus i Linneansk mening (= nyare botanisters Carduus och Cirsium). nDen lates åker... stod full med tisteln. Sal. Ordspr. 24: 30, 31.

Högt rest på tegen med sårande taggar Yfdes tisteln. ADLERBETH 58.

Borst-tistel, knappt taggig, med stjelkomfattande, dels hela, dels flikiga, på undre sidan hvita blad: Carduus heterophyllus L. Kallas vanligen Brudborste.

Jordtistel, utan tydlig stjelk: Carduus acaulis $\mathbf{L}$.

Krustistel, med på stjelken nedlöpande, krusiga blad: Carduus crispus L. Akerogräs.

Kåltistel, föga taggig, bladen stjelkomfattande, parbladigt inskur- na, blomhufvuden med breda, hjertlika skärmar: Cnicus oleraceus $\mathrm{l}$.

Kärrtistel, bladen nedlöpande, parbladigt inskurna, småtaggiga, blomhufvuden utan skärmar: Carduus palustris L. - Jfr Linnés Vestg. resa 236.

Nicktistel, sloktistel, med stora, nedböjda blom hufvud: Card.nutans $\mathrm{l}$.

Piggtistel, mycket taggig: Carduus acanthoides $\mathbf{L}$.

Vägtistel, äfven Horntistel, blomhufvuden liksom bladen hafva langa, styf fva tornar: Carduus lanceolatus $\mathrm{L}$.

Akertistel, äfven Gortistel, Skroftistel, blomhufvuden i vippa, bladen icke nedlöpande: Carduns arvensis Sx. Serratula arvensis $\mathrm{x}$. Ett af de mest skadliga åkerogräs.

Anm. Flere med Tistlarne ej förvandta, men taggiga växter benämnas äfven Tistel, t. ex. Blátistel, Mjölktistel m. fl.

+ Tistelboll, m., se Bolltistel.

Tistelborre, m., en med 'listlarne beslägtad ört, skild genom glatt blomfäste och mera luden växt: Onopordon Acanthium L.

Tistelväxter, en afdelning af Blomhålksväxterna, hvars väsentliga kännemärken äro mindre i ögonen fallande, men som vanligen igenkännes på styf och oftast taggig växt samt stora och hårda, oftast taggiga blomhufvud: Cynarocephalo Juss.

† Tisteläpple, n. = Spikklubba.

+ Tistron, n. $=1$ ) enligt Liljeblad (F]. 2 uppl.) Tistelborre; 2) Svarta Vinbär. Jfr Distron.

Tjerp, Tjerprot, f., Upl., Jemtl. större arter af slägtet Syra, företrädesvis Hästsyra. (Tara hos Franckenius är troligen samma namn.)

+ Tjurgräs, n., Smål.= Ryltåg. (Sannolikt har namnet ursprungligen varit Furgräs.)

Tjuton, n., en i södra Sverige allmän benämning på Strätta. Se Linñés 
Sk. resa 359. Jfr Stut, såsom namnet uttalas i de norra orterna.

$\div$ Tjälablomma, f., Tjälablomster, n., Tjälatuppa, f., kallas mångfaldiga vårblomster, såsom Sippor (enligt Franckenius, Tillandz, Bromelius), Movippa (i Upl.), Kabbelök och Hästhofsört (i Dal.), Violer (enligt Retzius) m. fl.

Tjärblomster, n., Tjärört, f., mångåriga örter bland Näglikeväxterna, med purpurröda blommor, fem stift och vid basen flerrummigt fröhus: $V i$ scaria Rовнц. Allmänna Tjärörten ( $V$. vulgaris Rовн..) har stjelken klibbig vid lederna.

To (i stället för ull eller lin) ingår i flera ord, såsom Tonad, gemensamt namn på Hampa och Lin, Tobändel, Tåbengräs = Lin-snarrefva, Tobetel = Tufvigt Ängdun, och troligen äfven Tåtel, äldre Totel. Ordet står i nära förbindelse med Do i Dodra (Camelina), Eng. Dodder (Cuscuta), Tysk. Dot, hamptråd o: s. v., hvarföre man kunde vara frestad att antaga ett forrloradt stamord $\bar{p}$.

Tobak, m., en allmänt odlad ört, tillhörande Bolmväxterna: Nicotiana L. Utom den Allmänna Tobaken ( $N$. Tabacum L.) odlas Bondtobaken, skild genom rundadt trubbiga blomflikar: $N$. rustica $\mathrm{L}$.

$A n m$. Atskilliga växter, som brukats sâsom surrogat för Tobak, hafva äfven fått namn deraf; så har Arnica montana L. kallats Tobaksblomma, samt Achillea Millefolium L. (Dal.) och Tussilago Farfara L. (enligt Wahlenberg) Bröst-tobak.

Tof, m., benämnas flera tufviga gräs, egentligast kanske Aira caspitosa L. I Jemtland kallas Aira flexuosa 1. Tofhven, i Skåne Scirpus caspitosus $\mathbf{L}$. Mossatof. Tof kallas allmänt $\mathrm{i}$ Norrland äfven Festuca ovina L. m. fl. gräs.

Toffelblomma, f., en skön och sällsynt, högnordisk ört af Nosseväxternas familj, med enbladig och en- blommig stjelk, liffärgade blommor: Calypso borealis SALtsB. - I anseende till blommornas likhet fördes denria ört af Linné till slägtet Guckusko; och namnet Toffelblomma har tillagts båda.

Tofhren, se Tof.

† Tofsmossa utgår.

Tofsåxing, m., ett grässlägte med axlikt sammandragen vippa, treblommiga, plattade, gyttrade småax: Koelevia PERs. Den Blågrå Tofsäxingen (K. glauca $\mathrm{D}_{\mathrm{Ec} .}$.) är ett värderadt gräs på sandfält.

Tok, m., en utmärkt, für södra Öland egendomlig buske af Brumvïxternas familj och Fingerörtslägtet, från hvars öfriga arter den afviker genom trädstam: Potentilla fruticosa $\mathrm{L}$. "Tok kallas på Öland en buske, som i hela verlden är mycket rar». Linnés Öl. resa 63. - Tokens qvistar äro mycket sega och användas till qvastar m. m. Namnet synes härleda sig från Angl.Sax. tohs, seg.

Tolta, f., örtslägtet Mulgedium Cass., tillhörande Fibleväxterna, men har blå blommor och fruktfjun. Våra båda inhemska arter tillhöra ensamt Norrland och Lappland, och namnet synes vara af Lapskt ursprung. Wahlenberg skrifver Tort, Torta.

Tolubalsam, m., se Balsamträd. it Tomtört, f. $=$ Harkål.

Toppklocka, f., en art af slägtet Blåklocka, med blommorna gyttrade i toppen: Campanula glomerata $\mathrm{L}$.

Topplösa, f., en art af slägtet Videört, eller snarare ett eget slägte, med gula blomklasar endast ur stjelkens bladveck, hvarigenom stjelkens topp är obegränsad: Naumburgia thyr'siflora (L.) Rexor.

+ Tordyll, m., efter Lat. Tordylium L. Hvarken växten eller namnet finnes i Srerige.

$\div$ Tormentill, efter Lat. Tormentilla, en art af Fingerörtslägtet; men 
då växten har ett godt och allmänt kändt Svenskt namn (Blodrot), finnes intet skäl att införa det främmande.

Torn, m. 1) pl. -ar. Förkrympta; stickande grenar. Spince. 2) utan pl. Allmän benämning på taggiga buskar. Jfr Törne. nTorn får fritt huggas af hvarjo, hvarmed förstås alla de buskar, som hafva taggar eller ock ej växa till synnerliga träd, dem man får utan syn bortrödja utur ängarna; sådane äro Hagtorn, Slånbärstorn, Vigeltorn, Njupontorn». Linnés Öl. resa 133.

† Tornört, f. Detta namn, en öfversättning af Lat. Turritis L., har troligen aldrig funnits utom i böcker och är nu platt obrukligt.

Torrvärksgräs, n. $=1$ ) Jemtl. Gul Ängsruta, Thalictrum flavum L. 2) Upl. Linnésört.

Torskblad, n., Torskblomma, f., Ångerm. = Bläcken. (I Dalarne, der ingen reda synes vara på växtnamnen, eller der man vid deras upptecknande ej förstått att frånskilja tillfälliga och på misstag beroende berämningar, är ifrågavarande namn tillagdt

Kabbelöken.)

Torske, se Tröske.

Torsklaf, se Laf.

Torste, Toste, se Tröske.

+ Tort, Torta, se Tolta.

Traf (= skida) ingår i flera namn, såsom Gulltraf, Himmelstraf, Rockentraf.

+Trampgräs, n. $=$ Fogelört $\left(P_{o}\right.$ lygonum aviculare $\mathrm{L}$.) samt flera andra örter, som växa på gårdar, vägar och trampade ställen. Jfr Vägört. - Fogelörten kallas äfven Trampnäfva, af det origtigt tillkomna namnet Näfva för Polygonum (se Näfva).

Tranbärsris, n., en på mossar växande, ständigt grönskande art af slägtet Vaccinium L., med liffärgade blommor och tillbakaböjda blomflikar: $V$. Oxycoccos L. Bären kallas Tranbär,
Tranjuter, Tränjon; de utmärka sig genom sin starka syrlighet.

+ Tranhals, $\mathrm{m} .=$ Näfva.

Tranvicka, se Vicka.

+ Tranärt, f. = Tranvicka.

Trebening, m., Skåne = Qvaller. Namnet afser de tredeladt-dubbelt sammansatta bladen.

Trefingerört, f., skild från Fingerörten derigenom att den har blott tre småblad och fem ståndare: Sibbaldia procumbens $\mathrm{L}$.

† Trifolium, rent Latin, och ett obehöfligt namn, då vi ega de Svenska Klöfver, Kolla, Väpling m. fl. på detta växtslägte.

Trift, Thrift, m., örtslägtet $A r$ meria wrün., med gräslika blad, bar stängel med ett blomhufvud och enfröig frukt. Odlas i trädgårdar under namn af Engelskt gräs, Gräsnäglika.

Trimjölksgräs, n., ett af Kabbelökens många namn, och anmärkningsvärdt är, att det genom Skandinaverna blifvit infördt i England. När växten blommar, anses tiden vara inne att mjölka korna tre gånger om dagen.

\section{† Trindgräs, n. = Trådtåg.}

Trip-madam, f., ett i Linnés tid vanligt namn på en odlad art af slägtet Fetknopp. (Sedum rupestre L.), hvilken användes till sallat. Så väl namnet som användandet äro nu helt och hållet förgätna.

Trollbär, n., ett gemensamt namn på vilda, icke ätliga bär, såsom 0rmbär, Trolldrufva, arterna af Solanum L.

Trolldrufva, f., en stinkande ört af Ranunkelfamiljen, men med svarta, i klase sittande bär: Actæa spicata $\mathbf{L}$. Bladen trebladigt sammansatta, blomklasarne hvita. Blott ett bär efter hvar blomma.

+ Trollkött utgår alldeles. 
† Trollslända, Trollkairingsläinda, f., Medelpad = Kungsljus.

Trollsmör, n., en gul, liksom jäsande slem-massa, som-mognad öfvergår till en Röksvamp : LEthalium septicum $\mathrm{F}_{\mathrm{R}}$.

† Trollspott utgår alldeles.

$\div$ Trollspy, f. = skyfall.

+ Trollägg, n., den i sitt slemfylda hylle ännu inneslutne Stinksvampen.

†Trollört, f., Wahlenb. = Hexört.

Troske, se Tröske.

† Trutlaf utgår alldeles.

Try, m., ett med Linnésört förvandt buskslägte, men med saftiga bär: $L o$ nicera $\mathrm{L}$. Hos de egentliga Tryarterna äro bären parvis sammanväxta, såsom hos Allmänna Tryen (L. Xylosteum L.) med röda bär; men sammanflyta till ett hos Blå-tryen ( $L$. crerulea L.) med mörkblå bär. Till detta slägte hör äfven Vrivendel (=Caprifolium), som likväl, emedan, den alltid i folkspråket skiljes från Try, upptages särskildt.

Tryffel, m., en talrik grupp af underjordiska Svampar, som inuti äro köttiga och ådriga, ej pulverulenta, och som räknas bland läckerheter: Tuber Iıсн. Den Äkta Tryffeln (T. cibarium PERS.) insamlas i södra Europa vintertiden efter dertill dresserade hundars anvisning, hvilkas luktorganer upptäcka hvar svampen är att söka. Blott en hvit art'Tryffel (Terfezia Leonis Tur.) är ett par gånger anträffad i Sverige.

\section{$\div$ Trynefrö, n., Upl: = Flenört.}

Trådlaf, se Laf.

Trådrot, f., ett köttigt, på jorden utbredt svampslägte, tillhörande Disksvamparne, utan fot, men uppburet af flere rotsträngar: Rhizina $\mathrm{F}_{\mathrm{r}}$. Om detta slägte upptages, kallas det bättre Trådrotssvamp.

Trådtåg, se Tåg.

+ Trädeslök, m. = Skärf-frö.
Trädgårds- tillägges som artnamn atskilliga odlade växter, t. ex. Trädgårdsmolla, -mynta, -näglika, -rättika, -smultron, -syra m. fl.

† Trädlaf, Trädmossa, Trädsvamp, Lafvar, Mossor och Srampar, som växa på träd, icke någon viss växt.

Trädlimsvamp (Bulgaria inquinans $\left.\mathrm{P}_{\mathrm{r} .}\right)$, se Limsvamp.

†Trädros, f. $=$ Törnros, i allmogespråket.

+ Trädvefla, f., klängväxt, som fäster sig vid eller omslingrar träd, $t$. ex. Murgrön.

Träfrätare, m., ett skorplikt utbredt svampslägte, på ytan nätformigt ådrigt eller fålladt, växande på och förstörande trä, synnerligast af Tall: $M e$ rulius (Harz.). Den skadligaste arten deraf är känd under namn af Svamp i hus (M. lacrymans WuLf.).

Träggan (sammandr. af tre-äggan), f., Upl. de arter af slägtet Igelknopp, som ha trekantiga blad : Sparganium ramosum och simplex Huds.

+ Träjon, n.?, Smål., se Hultabräken.

Trälmossa, se Mossa.

†Tränjon, n., se Tranbärsris.

+Trätogrås, $\mathrm{n}_{\text {. }}=$ Gulmåra.

Tröske, Troske, Torske, Tröste, Torste, Toste, n., se Brake. Tröskebuskens barksáft anses som ett specificum mot torsk; deraf namnet.

+'Tuberos, f., en utländsk Liljeväxt, högst sällan odlad i Sverige : $P_{0-}$ lyanthes tuberosa $\mathrm{L}$.

Tuf- tillägges àtskilliga växter som artnamn, t. ex. Tufstarr, -ticka, -tåda eller -tåtel, -ängdun m. fl. Se slägtnamnen.

Tulkört, f., en mångårig ört med motsatta, äggrunda blad, hvita blomklasar utgående från bladvecken, frön inom tvenne frukthylsor, omgifna af fjun: Cynanchum Vincetoxicum R. Br. 
Tulpan, rätteligen Tulipan, m., en allmänt känd och odlad Liljeväxt, skiftande i Hlera färgförändringar: $T u$ lipa Gesneriana i.

Tulpanens skrumpna blad sig mer och

Vid regnets glesa skur. mer tillsluta.

BELLMAN 4: 76.

Tulpantraid, n., ett prydligt Nordamerikanskt träd med tulpanlika blommor och flere småfrukter: Liviodendron tulipiferum $\mathrm{l}$.

\section{Tundersvamp = Fnösksvamp.}

T'ungört, f., ett örtslägte af Skrufblomstriges familj, med sträfhåriga blad, blå och i svalget af uppstående knölar tillslutna blommor, släta frukter: Anchusa I.

Fårtungört (A. arvensis В1EB.), ettårig, späd, med krökt pip.

Oxtungört (A. officinalis L.), mångårig, med starka, plogen hindrande rötter; deraf äfcen kallad Rast, Jernrot.

Tuppa, f., i vissa landsorter benämning på blomma.

†Tuppkam, m., öfversättning från Latin, liksom Hanekam (se der). Ett alldeles obrukligt namn.

\section{Tuschlaf, se Laf.}

† Tusenblad, n., öfversättning af Myriophyllum. Det Svenska namnet är Vattenslinga.

$\div$ Tusengodt, n., Skåne = Kattmynta enligt Retzius, Jordrefva enligt Linné. lika.

$\div$ Tusengren, m., Dalarne $=$ Röl-

$\div$ Tusengyllen, Tusendygdegräs, n., ur kräuterbücher lånade namn på Erythroea RicH., hvilka ej tillhöra Svenska språket och nu äro föråldrade. Vårt folkspråk har bevarat det gamla, dyrbara namnet Arun, som måste föredragas.

Tusenskön, f., hos Franckenius benämning på de utländska arterna af slägtet Amarantus L.; i det nyare språkbruket tillägges namnet flere odlade värter med fylda blommor, såsom Gul Tusenskön (Kanunculus repens L.), Hvit Tusenskön (Achillea Ptarmica L.), Röd Tusenskön (Bellis perennis L.). Men namnet Tusenskön tillhör mera det förnämare trädgåndsspråkct än folkspråket.

Jag är en vacker tusenskön,

Som bör i kransen ha min lön. V. DALIN 5: 358.

\section{$\div$ Tuska, f. = Spergel.}

Tnssilago, f., Latinska namnet på Hästhofsörten. Förekommer hos poeter, t. ex.

Tussilago pryder redan

Iånget knapphål med sitt gull. XYBLOM 143.

† Tusta, f., Boh. namn på Klöfverslägtet, t. ex. Rödtusta = Rödklöfver.

Treblad, n., ett örtslägte bland Nosseväxterna, lätt igenkändt af tvenne motsittande blad på stjelken: Listera R. Br.

Tråhjertbladsväxter, Dicotyledonec. Se Hjertbladsväxter.

$\div$ Tyde, f., Hall. = Hundkax. Efter Danskan.

+ Tysk Pil = Korgpil.

† Tyska Klockor, Blek.=Ackeleja.

† Tyska Rofvor, Skåne = Hundrofva. Se Linnés Sk. resa 112.

† Tysling (Boh.), m., Tyttebär, n. = Lingon.

+ Tåbengräs, n., Ångerm. = Linsnarrefva. Se To.

Tåda, f., ett grässlägte med yfvig vippa, tvåblommiga småax och på kronskalens rygg fäst borst: Air' $\mathrm{L}$ L. Kallas

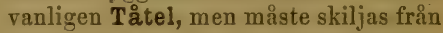
slägtet Holcus. Vi ha derföre för förstnämnda slägte upptagit det fornåldriga och ännu i Dalarne brukliga namnet Tåda. 
Kruståda (vanligen Kruståtel), spridt växande, med borstlika blad: A. Hexuosa $\mathrm{L}$.

Tuftåda (vanligen Tuf- eller Täkttåtel), tufvigt växande, med platta blad: A. cospitosa $\mathrm{L}$.

Tåg, m., ett artrikt örtslägte, till utseendet likt Halfgräsen, men med regelbundna, sexbladiga kalkar och trerummigt fröhus: Juncus $\mathrm{L}$. De talrika arterna häraf hafva redan af Linné erhållit Svenska namn, men vi anse tillräckligt att anföra de vanligares, af allmänheten urskildas :

Borsttåg, med syl-lika blad, blomvippa i toppen: J. squarrosus L.

Knapptåg, bladlös, med en grttrad blomknippa på midten af stjelken : $J$. conglomeratus $\mathrm{L}$. Kallas i södra Sverige Säf.

Ryltåg, med trinda, knutigt ledade blad: J. articulatus $\mathrm{L}$.

Trådtåg, lik Knapptågen, men är mycket spensligare, med trådlik stjelk och fa blommor: J. filiformis $\mathbf{L}$.

Veketåg, lik Knapptăgen, men med rik blomvippa på stjelkens midt: $J$. effusus L. Anvăndes till lampvekar.

†Tågbår,n.,Vesterb.=Stenhallon.

Tång, f., större hafsväxter af Algernas familj, men i inskränktare mening och i skriftspråket slägtet Fucus x.

Som hafstång -

På sandrefveln föres af svallande sjö.

De vigtigaste arterna äro: LING $1: 97$.

Knapptång eller Klot-tång, den allmännaste arten, med plattad, helbräddad, klynnedelad bål med tvenne motsatta blåsor vid förgreningarna: $F$ : vesiculosus $\mathrm{L}$. Kallas äfven Blåstång.

Knöltång, äfven Buletång, är jemväl tudelad, men ej plattad, och sjelfva grenarne äro pầ midten blåslikt uppsvälda: $F$. nodosus L.

Sågtång, lik Knapptången, men utan blåsor, och de plattade flikarne äro sågade: $F$. servatus $\mathrm{L}$.
Tårpil, f. = Sörjande Pil, se Pil. †Tårört, $\mathrm{f} .=$ Sileshår.

Tåtel, m., ett med Tåda förvandt grässlägte, men skildt genom växtens vekhet och fina ludd $\left(t_{0}\right)$ samt öfre blomman utan pistill: Holcus $\mathrm{x}$.

Den fina tåtelus räxt, som bärs på knutna leder. OXEXSTJEIRA 2: 30 .

Luddtåtel, ett allmänt odladt fơdergräs med ludna bladslidor: H. lanatus $\mathrm{L}$.

Vektåtel, med glatta bladslidor: H. mollis $\mathrm{I}$.

Anm. Namnet Tåtel har också förts icke blott till Tåda, utan äfren till sandborst, ¿enegräs och Smile, samt af äldre författare till Angkafle. Det härleder sig troligen från Tida eller $T o$.

Täfva, f., i sammansättuingen Hvitatäfva, härleder sig frân Isl. Defri, pefja, lukt, och tilläggges så väl Kamillblomster som Surkulla, båda utmärkta genom sin starka lukt.

Täkt-tåtel, se Tåda.

†Täpperocka, f., Skåne = Åkerfräken.

† Täpperot, f., har i våra floror upptagits som namu på Björnloka i stället för folkspråkets oanständiga Täpperöf, men derigenom förlorat sin betridelse. Enligt Linné (Sk. resa 266) var namnet föranledt deraf, att ifrågavarande växt af allmogen användes som medel mot dysenteri.

$\div$ Tärue, n., Medelp. = Dyfräken.

Tätört, f. (äfren Tätgrảs, Tätnacke), en liten ört, lätt känd genonn sina klibbiga blad, sin enblommiga, bara stängel sant läppformiga och med sporre försedda blomma: Pinguicula vulgaris L. Användes i Norrland till tätmjölkens beredning. (Genom förvexling har namiet $i$ Vestmanland blifvit öfverfördt till Sileshăr.)

$\div$ Töflor, f. pl. = Karborre.

Törel, m., ett artrikt örtslïgte med alldeles egendomligt bildade blommor och treknölig frukt, lättast kändt af den 
hrita, sharpa mjölksaft, som utflyter då räxten såras: Euphorbia L. Arterna hafva flera namn i folkspråket, såsom Reformsört, Reformsgräs, Ringormsgräs, Vårtgräs, Mjölkört m. fl. Jfr Mjölkört.

Törne, n. (Törnbuske), allmännast brukligt som plural af Torn (se detta ord) och tages i lika vidsträckt bemärkelse; men i bestämd mening tillägges det de vilda arterna af slägtet Rosa L., t. ex. Lukt-törne, Rosa rubiginosa $\mathrm{L}$.
Jag är en törnebuske trär,

Som likräl rackra rosor bär.

V. DALIX 5: 357.

Se, sjelfra törnet sig i rosor kläder. GRAFSTRüM 2: ̈̈.).

Töruros, f., de dubbla odlade förändringarna och arterna af slägtet $R$ iś L., på hrilka man i trädgårdssprảket har otaliga benämningar. De bekantare äro: Damascener-ros, Kanelros, Mossros, Månadsros, Provinsros, Theros, Ättikros, Hvit Törnros m. fl.

Den srällande törnrosen slutit sin mun. DAHLGREX 1: 255.

U.

$\div$ Uddbär, $\mathrm{n}$. $=$ 0 don.

+ Ugglebär, n., Ugglerönn, Ularönn, f., Kalmar län, Blek. = Olvon, Olvonbuske.

Uggleved, m., trä, som under förruttnelse lyser i mörkret. Har orätt ansetts härleda sig från en svampräxt.

$\div$ Ulfbär, n., Söderm. = Olvon.

Ulflaf, Ulfmossa, se Laf.

† Ullax, Ullgräs, $n$., nu alldeles obrukliga namn pả Ängull.

$\div$ Ullbär, n., Vesterg. $=$ Hallon.

$\div$ Ullklot, n., utgår alldeles.

$\div$ Ulra, f., Norrl., en obruklig benämning på Arre.

Umbell, f., en blomställning, hvari alla blomskaften utgå från en punkt och blommorna sitta i en jemnhög krets. Kallas i allmogespråket Kring- lov; men då Ümbell allmänt antagits i den botaniska terminologien, ha vi ansett lämpligast att bibehalla denna benämning.

Umbellaträxter kallas räxter med umbell och trenne frukter, som skiljas rid mognaden. Pâ Srenska Kringelväxter, men Umbellater är den allmännast brukliga benämningen.

† Underträd, n., utgår alldeles, såsom tretridigt, öfrerflödigt, obrukligt namn.

Underviol, se Viol.

† Upasträd, n., ett mycket giftigt träd på Java : Strychnos Tieute Lescrex.

† Utterbår, n., Vesterb. = 0don.

Uäringsgräs, n., Smål. = Dårrepe, Råglosta. Jfr Näringsgräs, Möllers ordbok öfrer Halländska landskapsmålet. 


\section{V.}

Vaksin (hos Liljeblad), m., örtslägtet Vaccinium L., hvars samtliga arter hafva sjelfständiga namn: Blåbär, Lingon, 0 don, Tranbär.

... de svarta vaccinier (d. it. blibär) plockas.

ADLERBETH 14.

Valbork, m. (Österg. Valbjörk, Boh. Valborg) $=$ Vägtorn.

Anm. Valbork, af Isl. börkr (bark), anser jag vara rätta uttalet af detta namn, ty Vägtornsbusken har ingen likhet med biörk. Jfr, bland Vägtornens benämningar i folkspråket, namnet Getbark. Denna buske synes vara Eddans svefn-porn (sömntörne), och ordet $v a l$ är väl liktydigt med drala.

\section{+ Valkullor, se Dvalkullor.}

Vallkrasse, m., en tvåårig Krasseväxt med bara stänglar, platta skidor med smal skiljevägg: Teesdalia nudicrulis $\mathrm{R}$. Br. Namnet upptages redan af Bromelius; Wahlenberg för det till Gatkrassen.

Vallört, f., ett slägte bland Skrufblomstrige, utmärkt genom sin slemmiga rot, på stjelken nedlöpande blad (hos de inhemska arterna) och lancettlika fjäll i blompipens svalg. Symphytum officinale L., med röda eller hvita blommor.

Anm. Växten har ansetts sårläkande, och namnet härledes af ralla, sammanvälla. Se Ihre.

Valmo, Valmoge, m., ett allmänt örtslägte med tråbladigt blomfoder, fyrbladig blomkrona med talrika ståndare kring en tjock pistill: Papaver $\mathrm{L}$. Alla Valmo-arter hysa hvit mjölksaft.

Denna valmo är präktig och skön. BELLMAX 1: 164.

Dess runda anlet friskt liksom en valmo prålar.

STAGNELIUS 1: 105.

Kornvalmo, sträfhårig; med klotrunda, släta frukter: P. Rhoeas L. Odlas ofta till prydnad.

Spikvalmo, med aflånga, styfhåriga frukter: P. Argemone $\mathrm{L}$.
Åkervalmo, med aflånga, glatta frukter: $P$. dubium $\mathrm{L}$.

Äkta Valmo, stor, glatt, med runda frukter: $P$. somniferum $\mathrm{L}$. Af denna erhålles opium i Orienten (hos oss är saften mildare).

Akern bräns ... af den slummergifvande valmon. ADLERBETH 56.

- doften af en valmo...

Söfver smärtan. GRAFSTRŌM. 2: 9 .

$A n m$. Hos alla äldre författare och af allmogen kallas örten Valmoge, Valmoga (Grek. "(l)(1)v, Lett. Maggon, Tysk. Mohn). Skrifves vanligen Vallmo; men i min tanke vore Dvalmo (jfr Tysk. Schlafmohn) rigtigast.

Valnötsträd, n., ett resligt träd, tillhörande Hängeväxterna, med blad liknande Askens, odladt i de södra landskapen för dess stora, ätliga nötter, kallade Valnötter: Juglans regia $\mathrm{L}$.

Valnötsträdets topp med nederfälda nötter

Beströr det vissna gräs, som gulnar kríng dess rötter.

OXENSTJERNA 2: 150 .

Anm. Ordet $v a l$ i detta namn utmärker Valsk eller Välsk och är sålunda alldeles skildt från val i Valbork, Valkullor, Valmo.

Vamstöt, m., Verml., Jemtl. = odon. (Af vam, vaim, buk.)

Vanilj, m., den mjuka massan inuti fröhusen hos en tropisk Nosseväxt: Vanilla aromatica Sw.

+ Varg, m., benämning pâ växter, som äro fiendtliga mot lien: Vievarg, allmänt; Gräsvarg, Dal. = Kärrfrier. Hit hör äfven af samma anledning Vargbasse = đkerstallört.

+Vargböna, f. Detta namn på några odlade utländska arter af slägtet Lupinus I.., hvarifrån namnet är en öfversättning, synes böra utgå, då de redan allmänt äro kända under benämningen Lupiner. 
$\div$ Vargdöda, f. $=$ Nordisk Stormhatt, Aconitum Lycoctonum L. Namnet är en öfversättning från Lycoctonum och har aldrig vunnit burskap i språket.

$\div$ Vargmjölk, f. = Kärrtörel, se Mjölkört.

† Vargtrut, m., Skåne= Blåeld.

Vass, Skärvass (jfr Kolvass), m., det största af våra inhemska gräs, med hvassa, skärande blad och yfvig, efter blomningen ullig blomvippa: Phragmites communis TrrN.

Jag bland den höga vass förgäfves letar stranden.

OXENSTJERNA 2: 26.

Leker och skär pipor uti vassen.

SEHLSTEDT 1: 10.

Anm. Namnet skrifves i de gamla landskapslagarne både Hvass och Vass, hos Bromelius Vass, hos Tillandz Hrass. Att det härledes af adj. hvass och utmärker det hrassa röret, synes otvifvelaktigt.

- Vassarv, Vannarv $=$ Våtarv.

Vassesvingel, $\mathrm{m} .=$ Fluminia arundinacea $\mathrm{F}_{\mathrm{R} .}$, se Kase.

$\div$ Vassviol, f., Wahlenberg $=$ Blom. vass.

Vatten-andorn, se Andorn.

Vattenarr, m., ett med Stjernblomman förvandt slägte, skildt genom fem pistiller, femflikigt fröhus: Ifalachium aquaticum $\mathrm{Fr}_{\mathrm{R}}$.

+Vattenbinda, f. $=$ Snärjegräs.

Vattenblink, se Blink.

+ Vattenbläddra, f., Liljeblad $=$ Bläddrerot.

Vattenglunga, f., på vatten flytande, blågröna Alger; derom säges äfven: "vattnet blommar".

$\div$ Vattengran, f., Smål. = Ledgräs.

$\div$ Vattenhyll, m., Bromelius $=$ Olvonbuske.

Vattenklöfver, $\mathrm{m}_{:^{-}}^{-=}$Bläcken. Torde, såsom varande ett mera all- mänt brukligt namn, böra upptagas som synonym.

† Vattenkrasse, m., Retzius = Källkrasse.

†Vattenkula, f., algslägtet Riı'ularia Roтн. Förtjenar ej upptagas.

Vattenlilja, f., i poesi benämning på vackra vattenväxter; vanligen afses dermed Neckrosen, men lämpligast Svärdsliljan.

+ Vattenlins, m. = Andmat.

-Vattenlök, m. = Dyborre.

Vattenmärke, n., Sium latifolium

L. Se Märke.

$\div$ Vattennöt, $\mathrm{f} .=$ sjönöt.

+Vattenpeppar, m., öfversättning af Hydropiper, $=$ Brännande Pilört.

Vattenpilört, se Pilört.

$\div$ Vattenrotsblomster, $n,=$ Refvigt Solöga.

$\div$ Vattenrysja, f., öfversättning af Hydrodictyon Roтr; ett slägte bland Algerna.

+Vattenröllika, $\mathrm{f}_{\mathrm{f}}=$ Vattenblink.

Vattensenap, m., de gulblommiga arterna à slägtet $N$ asturtium R. Br., sasom $N$. amphibium, silvestre $\mathrm{m}$. fl.

+ Vattenserf, m., Liljeblad $=$ Hårserf.

Vattensilke, se Silke.

Vattenslinga, f., ett $\mathrm{i}$ djupare vatten växande örtslägte med hårfina, parbladigt delade blad och uppskjutande endast blomaxet ofvan vattenytan: Myriophyllum L. Stjelkarne äro veka, slingrande; deraf benämningen. Namnet Slånga (Haf-slånga), tillagdt Zostera L., synes vara samma ord som Slinga.

+Vattenslinke, n., se Slinke. Torde vara blott ett olika uttal af Vattenslinga, men föres till en annan, snarlik växt, nemligen Nitella AG. 
Vattensolögà, se Åmöja.

Vattensyra, se Syra. borre.

Vattensåga, f., Liljeblad $=$ Dy-

† Vattentistel, m. Under detta namn skall i Angermanland förstås både Mjölkfibla och Kärrtistel.

$\div$ Vattentulpan, m., Gotland $=$ Neckros. Särdeles opassande benämning.

$\div$ Vattenviol, f., Wahlenberg $=$ Vattenblink.

$\div$ Vattenväpling, $m .=$ Bläcken.

Vau, m. (n.?), en värdefull färgväxt medilancettlika blad och små, gröngula, $i$ ett ax sittande blommor med flikiga kronblad: Reseda Luteola $\mathrm{L}$.

Än Sveriges egen jord för sina strids-

mäns drägt

Är af det gula vau och veidets azur täckt.

OXENSTJERNA 2: 123.

Vaxbuske, m., en i Nordamerika inhemsk buske af slägtet Pors, ur hvars frukter utkokas ett slags vax: Myrica cerifera $\mathrm{L}$.

Vaxpalm, f., en palmart i Sydamerika, af hvars hela stam utsvettas ett vaxartadt ämne: Ceroxylon andicola Немв.

Vaxskifling, m., ett slägte bland Skifsvamparne, med saftfulla skifvor: Hygrophorus Fr.

. $\div$ Vaxäpple, n., en förändring af Äpplen, hvars namn tillhör trädgårdsspråket.

Ve, se Vera.

Vedel, Vele, m. = Ängsvial. Enligt Wahlenberg ärnamnet en flexion af Vial.

† Vefla, f., klängväxt.

Veide, m. (n.?), en bekant färgväxt, tillhörande Korsblomstrige, utmärkt genom sin yfviga vippa och sina enfröiga, vingade, icke uppspringande skidor: Isatis tinctoria $\mathbf{L}$.
Vekare, m., honträdet af Jolsterpilen. Fröfjunet har användts till lampvekar.

Ceketåg, se Tåg.

Vekbitel, se Tåtel.

+ Velamsrot, Velantsrot $=$ Vänderot.

Vele, m., se Vedel.

Vera, Ves, Ve, Verf, Viva m. fl., en inom olika landskap $i$ oändlighet vexlande benämning på Sippor. Jfr Bot. utfl. 3: 206, not.

$\div$ Vespelten, m., Vesterg. = Mistel. "Gemene man trodde, att då denne $V$ speltenen hängdes $i$ huset, skulle det vara säkert för vådeld»。 Linnés Vestg. resa 31.

Vevling, $\mathrm{f}_{\mathrm{.}}=\AA \AA$ Akerbinda.

Via, Vija, f. Detta namn, som ingår i flera sammansättningar (t. ex. Kasevia) och sannolikt är stamförvandt med Vial och med vall (i $\mathbf{K}_{0}$ vall) samt, enligt Wahlenberg, äfven med Vele och Hven - allt benämningar på de yppersta foderväxter -, synes beslägtadt med Mösog.vinja, foder.

Vial, m., ett slägte bland Ärtväxterna, med stora parblad och klänge samt stora, mångfröiga baljor: Lathyrus $\mathrm{L}$. Hit höra de yppersta foderväxter.

Hafsvial, med många breda parblad och blå blommor: L. maritimus Brgar. Kallas af Linné Hafsärter, Strandärter: Pisum maritimum $\mathrm{x}$.

Kärrvial, med smala blad och blå blommor: L. palustris $\mathbf{L}$.

Skogsvial, med mycket långa blad och röda blommor: $\dot{L}$. silvestris $\mathrm{L}$.

Ängsvial, med gula blommor: $L$ : pratensis $\mathrm{L}$.

Anm. Namnet Vial, Viar föres i allmogespråket ofta till arter af slägtet Vicka.

Vicka, f., ett artrikt slägte bland Ärtväxterna, skildt från Vial genom på undre sidan ludet märke (hos Vialen glatt): Vicia L. Af dess arter urskiljas i folkspråket: 
Fodervicka, ettårig, allmänt odlad foderväxt: $V$. sativa L.

Kråkvicka, flerårig, finluden, slankig växt med talrika blommor på ụtdragna skaft: $V$. Cracca $\mathrm{L}$.

Tranvicka, flerårig, med korta, fåblommiga skaft: $V$. sepium 1 .

+ Victoria regia (Lixd.) eller Vattnens Drottning, en af de största blommor i verlden, tillhörande Neckrosorna, växande i Amazonfloden.

Vide, n., en afdelning af slägtet Pil (Salix L.), hvilken innefattar talrika buskväxter, blommande på bar qvist, med långskaftade fröhus: Vetrix $\mathrm{F}_{\mathrm{R}}$.

Videt, som sin gång från bäckens sanka brädd

Med rötters krypning stjäl och röjs $i$ gräsets bädd. OXEXSTJERNA $2: 30$.

Bandvide, med glatta knoppar och qvistar, finludna, skrynkliga blad: $S a$ lix aurita $\mathrm{L}$. Användes till tunnband, vidjor $\mathrm{m}$. $\mathrm{m}$.

Gråvide, med ludna qvistar, knoppar och blad: S. cinerea L.

Grönvide, med glatta, gröna, men under torkning svartnande blad: $S$. nigricans (Sss.).

Jordvide, en lagg, i jordbrynet krypande buske: $S$. repens $\mathbf{L}$.

Utom dessa finnas åtskilliga andra arter, såsom Gulvide (S. bicolor $\mathrm{H}_{\mathrm{R} .}$ ), Lagervide (S.laurina SAr.), Rosmarinvide (S. rosmarinifolia L.) $\mathrm{m}$. fl. Se Bot. utfl. 3: 293 o. följ.

\section{+ Videvier, se Vira.}

Videört, f., ett slägte bland Hvifveväxterna, med bladig stjelk, gula blommor och vid basen sammanvuxna ståndare: Lysimachia L. Allmänna Videörten har stor blomruska i toppen: $L$. vulgaris I.. Jfr Penningört och Topplösa.

Vif, m.?, Nerike = Gullpudra.

Vifva, se Hvifva.

†Vigeltorn, se Väretorn.
Vija, se Via.

Vikon, n., en ört af Hallonslägtet, med trefingrade blad, röda blommor och-utmärkt läckra frukter: Rubus arcticus L. Frukten kallas vanligen Åker$b a ̈ r$, men detta namn är särdeles opassande (i södra Sverige tillagdt Hallon), och önskligt vore att den ypperliga fornnordiska benämningen Vikon (= de heliga bären) allmänt antoges. Jfr RiETz Ordbok.

Vild-, Vill-, ett vanligt epitet till vilda arter, som närma sig en odlad art, eller till vilda stånd af en äfven odlad växt, t. ex. Vildapel, Vildpäron, Villhafre,Villdrufva (= Trolldrufva), Villhumle, Vild Fläder, Vild Körs, Vildt Lin eller Hör, Vild Morrot m. fl.

Vild Cypress, m., Wahlenberg $=$ Klådris.

Vild-dodra, se Dodra.

Vildpalsternacka, se Palsternacka och Bolmört.

Vildpersilja, f., se Glis.

+ Vildpesa, f., Vesterg. = Dårrepe.

+Vildpoley $=$ Dosta. Namnet är upptaget ur Tyska kräuterbücher och har aldrig tillhört Svenskan. Jfr Stenpoley.

+ Villbär, n., se Trollbär.

+ Villoreda, f. = Gulmåra. Jag anser namnet ursprungligen hafva varit Hviloreda, emedan växten begagnats i stället för bolster i sängar. Jfr slägfrid.

+Villpors, m. = sqvattram.

+ Villsqvattram, $\mathrm{m} .=$ Pors.

Vilster, f. = Jolster.

Vinbårsbuske, m., tvenne arter af slägtet Ribs, utan taggar, med ätliga bär: Ribes L.

Röda Vinbär, R. rubrum L.

Svarta Vinbär, $R$. nigrum L. 
Vinda, Vindelört, f., ett örtslägte med slingrande stjelk, som flätar sig kring andra växter, och vackra, klocklika blommor: Convolvulus L. Namnet förvexlas ofta med Binda.

Skogsvinda, med hjertlika blad: C. sepium $\mathrm{L}$. Ofta odlad för sina stora, vackira blommor.

Akervinda, med pil-lika blad: $C$. arvensis I. Ett svårt åkerogräs.

$\div$ Vindgräis, n., enligt Linné benämning i Angermanland på Linnésört, men enligt Rietz rättare Vinngräs (af vinn, värk) och således motsvarande namnen Benvärksgräs (Österb.), Torrvärksgräs (Upl.) på samma ört.

Vingblomma, f., benämnes af Franzén Phyllocactus phyllanthoides Deo. (i trädgårdsspråket Cactus alatus wirLd.), hvilken han egnat ett vackert skaldestycke.

Viupalm, fo, en palmart i Ostindien, ur hvars afskurna stänglar flyter en sockerhaltig vätska, af hvilken genom jäsning beredes vin: Borassus flabelliformis $\mathbf{L}$.

Vimranka, äfven blott Ranka, f., en verldsberömd, mångårig klängväxt från Armeniens och Caucasi dalar, af hvilken erhålles Vindrufvan, vinets moder: Vitis vinifera $x$. Ingen växt framträder i så talıika artförändringar som Vinrankan. Hvarje folkrace har sina egendomliga spritväxter; Vinrankan är egendomlig för de Caucasiska eller Indogermaniska folken och är den ädlaste, icke förslappande såsom Opinm $\mathrm{m}$. fl.

En skönare verld,

Der rankorna skailfva

I almarnas topp,

Der bäckarne hvälfva

Bland myrten sitt lopp.

STAGNELIUS 2: 183.

Vinruta, f., en mångårig, fordom allmänt, nu sällan odlad växt, med grenigt delade blad och flikiga frukter, lätt känd genom sin vidriga lukt: Ruta graveolens $\mathrm{I}$.
Vintex- tillsättes vissa växtnamn, dels för att utmärka artförändringar, dels som artnamn, t. ex. Vinterrăg, Vinterhvete, Vinter-rapunzel $\mathrm{m}$. $\mathrm{fl}$.

Vintergröna, f., ett ständigt grönskande örtslägte, närmast beslägtadt med Ljungväxterna, men med breda rotblad, klasvis sittande blommor och fria kronblad: Pyrola 1. - Namnet, i alla Germaniska språk antaget för $P y$ rola, har af okunnighet blifvit fördt äfven till Sinngrön.

Vinterkiasse, se Sommargyllen. Vinterlaf, Vintermossa, se Laf. Vinternypon, se Nyponbuske.

Vintråd, n., Österg. = Murgrön. - Murgrön har från äldsta tider sammanbundits med Vinrankan såsom dess symbol. ("Ubi vinum bonum, non opus est suspensa Hederan. Lat. ordspråk.)

Viol, f., ett artrikt örtslägte med fembladiga, oregelbundna, med sporre försedda blommor: Viola I. Jfr Fiol. Bland arterna urskiljas af allmänheten:

Luktviol, utan bladig stjelk; blommorna mörkblå, välluktande: $V$. vंdorata $\mathrm{L}$.

Marsviol, äfven Buskviol, lik den föregående, men utan rotskott; blommorna ljusblå: $V$. hirta L. - Dessa båda arter blomma tidigt om våren.

Skogsviol ( $V$. silvaticu $F_{r}$.), med breda, hjertlika blad, och Hundviol ( $V$. canina L.), med aflanga blad, hafva båda bladig stjelk och mörkblå blommor och förenas vanligen.

Styfmorsviol, ettårig, med flikiga biblad och trefärgade blommor: $V$. tricolor $\mathrm{L}$. Odlas i flera förändringar; äfven af den vilda finnes en afart med små, nästan gula blommor: var. bicolor.

Underviol har tvenne slags blommor, från roten fullständiga (med kronblad på enkla skaft), från stjelken utan kronblad: $V$. mirabilis $\mathrm{L}$. 
+ Violrot, f., roten af en i södra Europa växande art utaf Svärdslilja: Iris florentina $\mathrm{L}$.

Violsten, $m$. , kallas nyligen omvältrade stenar (t. ex. vid vägar), som blifvit beklädda af en liten, välluktande, röd Alg (Chroolepus Jolitlus AG.), hvilken gnuggad blir gul, torkad gràgrön.

† Vipefett, Vipegräs, n., Skåne $=$ Tätört.

+ Vipestjert, m., Skåne = Ängkrasse.

Vippa, fo, ett af Linné med Sipporna förenadt slägte, skildt genom mångklufvet svepe och småfrukternas fjunhåriga borst: Pulsatilla Mrru. Nảmnet, brukligt i Nerike och flerstädes, är särdeles karakteristiskt.

Backvippa (Backsippa), med findelade blad och klocklika blommor: $P$. vulgaris ঐrLs. Allmänt känd.

Fältvippa, lik den föregående, men blommorna slutna, med i spetsen utböjda kalkblad: P. pratensis Mris.

Movippa, med enkelt parbladigt delade blad, utstånde kalkblad: $P$. vernalis MIrr.

Vippärt, f., ett till Ärtväxterna hörande slägte, skildt från Vial endast genom saknaden af klänge: Orobus $\mathrm{x}$.

Knylvippärt,med hinnkantad stjelk, knölig rot: O. tuberosus L. Allmänt kallad Gökmat.

Svart Vippärt, med grenig stjelk, 5-8 parblad; svartnar torkad: $O$. $n i-$ ger L.

Vårvippärt, med enkel stjelk utan hinnkant: $O$, vernus $\mathbf{L}$.

Vira, f., en afdelning af slägtet Pil (Salix L.), omfattande buskar med smala, vidjelika qvistar, nedtill motsatta blad, sammanväxta ståndare och oskaftade frukter: Helix $\mathrm{Fr}_{\mathrm{r}}$. Den allmännaste arten är Rödvira, Salix purpurea L. Videvier, Linnés Sk. resa 58. $\div$ Virenbom, $\mathrm{m}_{.}=$Vrivendel.

† Virretorn, m., se Väretorn.

Visil, m., en mångårig ört med ett hjertlikt blad på den enblommiga stjelken, blomman hvit, Hvit Visil : Parnassia palustris L. Namnet är beslägtadt med flexionerna af Ves.

Viskmossa, se Mossa.

Vispmossa, f., arter af Lummerslägtet; äfven = Björnmossa.

Viva, se Vera; jfr Hultaviva. björk.

+Vivang, m.?, Verml. = Dverg-

Woodsört, f., ett mycket opassande namn på Hällebräken, som ej kan kallas ört.

Vresalm, f., se Alm.

Vrivendel, m., Vrivångeliträd, n., det inhemska namnet på Caprifolium, hvilket är ganska karakteristiskt.

Vår-, ett af de vanligare artnamnen, äfven tillagdt artförändringar, $t$. ex. Vårråg, Vårhvete.

Vår-adonis, se Adonis.

Vårbrodd, $m$., ett allmänt, tidigt blommande grässlag, med sammandragen vippa, hvilket, i synnerhet torkadt, utmärker sig genom vällukt och ger hö dess behagliga lukt: Anthoxanthum odoratum $\mathrm{x}$.

Och myskans välluktgräs, bland fältets vårbrodd född,

Af värman utan konst för dira fötter strödd. OXEXSTJERNA 2: 122 .

Vår-fingerört, se Fingerört.

Vårfrudagslök k, se Vårlök.

+ Vårhane, $m_{.}=$Harsyra.

+ Vårhvita, f. = Snöklocka.

Vårlök, m., en liten, gulblommig Liljeväxt med lökstam, blommande tidigt om våren: Gagea lutea Kre. Benämnes i folkspråket Vårfrudagslök.

Vårsallat, m., ett ettårigt örtslägte, nära förvandt med Vänderoten, men 
har fintrådig rot och saknar fruktfjun: Vuleriunella Tours. Jfr Rapunzel.

Vårstarr, se Starr.

Vårtgräis, se Törel.

† Vårtlaf (Verrucaria PERs.) utgår.

Vårvippärt, se Vippärt.

Våtarv, m., ett i södra Sverige allmänt brukligt namn på en art af slägtet Stjernblomma : Stellaria media (L.). Sångfoglars vanliga föda är Vàtarv.

Vädd, m., är gemensamma benämningen på de växter, som af Linné fördes till slägtet Scabiosa r., hvilka likna Blomhålksväxterna, men hafva endast fyra fria ståndare. De förra Latinska artnamnen begagnas nu delvis som slägtnamn.

Knappvädd, med enkla, lancettlika blad och blå blommor: S. succi$s a \mathrm{l}$.

Stjernvädd, med findelade blad och ljusblå blommor: S. Columbaria $\mathbf{L}$.

Åkervädd, med parbladigt inskurna blad och gredelina blommior: $S$. arvensis $\mathrm{I}$.

+ Våddklint, m., enligt Liljeblad och Wahlenberg Stor Knoppört (Centaurea Scabiosa L.).

Väderleksmossa, se Mossa.

Vägbreda, f., Dansk benämning på Groblad, allmänt bruklig i de förra Danska provinserna. Förvridet Väfveredsblad, se Linnés Sk. resa 240.

Vägglaf, se Gull-laf.

†Vågglusgräs, $n$. = Stinknäfva.

Våggmossa, se Mossa.

$\div$ Väggört, f., en öfversättning af Lat: Parietaria, hvilken dock icke är autagen $\mathrm{i}$ Svenska språket, $=$ Blidnässla.

$\div$ Vägkrasse, m. = Vägsenap.

Vägsenap, m., ett örtslägte bland Kålväxterna, med små gula blommor, smala, trinda skidor: Sisymbrium L.
Allmän Vägsenap, med rundtaggade blad: S. officinale soor. Kallas i Vesterg. Dufkăl.

Finbladig Vägsenap, med mycket findelade blad: S. Sophin L. Frön af denna m. fl. kallas Stillfrö.

Vägtistel, se Tistel.

Vågtoru, m., en taggig buske med blad liknande A pelns (deraf kallad Getapel), men med små fyrbladiga blommor, klasvis sittande på grenarne, och svarta bär: Rhamnus catharticus I.

Vägvårda (Tysk. W'egwarte), f, en stâtlig växt af Fiblornas familj, med blå blommor utan fruktfjun: Cichorium Intybus L.

+Vågo̊rt, f., är, i likhet med Trampgräs, ett obestämdt namn, tillagdt Knytling, Fogelört, afdelningen Avicularia Mriss. under Polygonum L., och så mycket mindre användbart som flertalet af arter växer upprätt.

+ Vämblad, n., Dalarne $=$ Neckblad.

Vänderot, f., ett slägte bland Fläderväxterna; utmärkt genom torr frukt (ej bär) och fruktfjun: Valeriana $\mathrm{I}_{\text {. }}$. Äkta Vänderot har bladen parbladigt sammansatta, tvåkönade blommor: $V$. officinalis L. - "Tibast och Vänderot stà mig emot", säger trollpackan i en folksaga.

Våpling,.m. Detta namn är af ålder tillagdt Ärtväxter med blommor i ett hufvud, således slägtena Trifolium L. och Anthyllis L. Det förra slägtet kallas nu allmänt Klöfver, och arterna Backväpling; Gullväpling, Hvitväpling, Rödväpling $\mathrm{m}$. fl. återfinnas under Klöfver. Det är fördenskull allt skäl att bibehålla namnet Väpling för Anthyllis, som icke eger något annat $\mathrm{i}$ skriftspråket användbart namn. $A . V u l$ neraria I. kallas från äldsta tider Getväpling och skiljes från Klöfverarterna genom parbladigt sammansatta blad. 
Väretorn, $m$.=Vägtorn. Namnet härledes af ädur och öfverensstämmer med dennes benämning i främmande sprỏ ${ }^{2}$, men är nu i vart folkspråk till orgenkännelighet förvridet, såsom Virretorn, Vigeltorn o.s. v.

Värkört, f. = Ältgräs.

Vätteljus, n., den vilda, hvitblommiga Bellis perennis I., allmän i Skåne. Namnet är i folkspråket på mångfaldigt sätt förvridet (i Skåne enligt Linué Futteljus). Teckningen Vätte- ljus synes mig vara den enda användbara. Jfr Bot. utfl. 2: 124 not.; 3: 210 .

Vätteros, f., en köttig, liffärgad växt, utan örtblad, men rotstocken har tjocka, öfver hvarandra liggande fjäll: Lathrce Squamaria L. I anseende till Vätterosens underjordiska växt, mystiska utseende, men vackra liffärg, har hon med allt skäl blifvit egnad de underjordiské eller vättarne.

Vävling, se Vevling.

\section{Y.}

Yams, se Jams.

Ylle, n., ett Algslägte med ulligt ntseende: Ectocarpus Lrмaв.

Yx", Yxne- brukas i flera landskap i st. f. Oxe; sålunda säges Yslägg för
Oxlägg, Yxneöron för Oxöron, Yxnegräs, Yxnepes (= Nosserot) för Oxgräs o. s. v. Yxne, af Liljeblad antaget som namn på Nosseväxter, var olyckligt valdt.

\section{Z.}

+Zederack, m., bark och blad af Melia Azedarach I., fordom använda i medicin.

+Zedoaria, f., en Ostindisk krydda, rotstocken af Curcuma Zedoaria Rosc. Kallas äfven Sittver.
Zymbel, m., ett örtslägte bland Nosseväxterna, med trådlika rötter och päronformiga, hängande frukter: Epipactis Rrсн. Jfr syssla.

\section{A..}

Årodd, rigtigare Abrodd.

Åkanna, f., frukten af Neckblad och Neckros.

Åker- tillägges må̊ngfaldiga växter șom artnamn, t. ex. Akerbinda, -do- dra, -fräken, -gyllen, -hven (=Kösa), -klint (=Klint), -kovall, -kullor, -kål (Brassica campestris L.), -lins (= Äkta Lins), -madd, -mjölkfibla, -mynta, -rofva, -rättika, -senap, -skalleblomma, -skärffrö, -solöga, -spergel, -stal'. 
ört, -tistel, -valmo, -vinda, -vädd, -ärenpris (V'eronica agrestis I..), -ärt m. fl. Se under slägtnamnen.

$\div$ I̊kerarv, m. = Rödarv.

İkerbair, v. =-1) i Göta rike Hallon; växa helst i årarnes steurör; 2) i Österbotten och i riksspråket Vikon. Se detta namn.

Tan mot de åkerbär, som, hägnade vid polen,

Bland Fruktgudinuans barn allena rä̀das solen. oxExstjersa 2: 54.

$+\AA$ Åkerdön, $\AA$ Åerdöer $=$ Blinddån (se Blindnässla).

Åkerfälle, se Fãlle.

† I̊kerkåpa utgår alldeles.

+ I̊kerleja, se Ackeleja.

† Åkermönja, f., en meningslös förvridning af det Latinska Agrimonia = Småborre.

+ Åkerrast, f., en benämning, som i systematiska skrifter högst opassande blifvit tillagd Fårtungörten.

Åkerros = Blåklett (Blåklint). + Åkerrym, m. = Åkergyllen. Förkastligt namn.

Åkerrök, se Jordrök.

İersilke (efter det Danska Agersilke), n., tillägges ranligen Jordrök, men stundom äfven de rilda Valmoarterna.
+ Ilkersuga, f., benämning pâ de bland siid vïxande arterna af sligtenn Dån och Plister.

I̊landsrot, se Alant. Alldermjölk, se Mjölke.

Ålgräs, n., en i vatten räxande art af slägtet Fräken : Dy fräken.

Allon, n., frukten af Ek, Bok, Annbok och Äkta Kastanie, hyilka träd. jemte Hasseln benämnas Ållonträd. Nammet härleder sig, enligt Ihre, frann ala, nutrire, och till grund derför ligrger således samma begrepp som för . Ekens och Bokens alla äldre namn. Jfr Bot. utfl. 3: 220.

Allonmärke, n., den i Göta rike allmännast brukliga benämningen på Kropp. Jfr Mjölke.

Alnate, m., se Nate:- Äfven Grodnaten benämnes stundom Alnate. Jfr Grodnate.

Åm, m., Öland, Österg. = Ag.

$\div$ Åmöja, f., benämning i folksprâket på en art af slägtet Solöga (Vattensolöga, Ranunculus Lingua $\mathrm{L}_{\text {e }}$ ) med upprätt stjelk, naggtandade, lancettlika blad. Det har synts mig tvifvelaktigt,

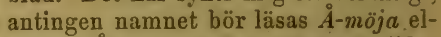
ler ock $\AA m$-öga , hvilket passar särdeles väl på ifrågavarande, bland åm (ag, vattengräs) växande art. Jag antog det senare till dess jag fann möja som slägtnamn på andra växter, t. ex. Svalörten.

I̊sknässla, İsknita, f.= Hjertstilla.

Ä.

$\div$ Äckergräs, n.= ̊kerkullor. Namnet skrifres väl orätt Eckergrüs, då det härledes af äckra, hvilande åkerfält.

$\div$ Äfjeblomma, f. = Blomvass.
Ïfjebrodd, m., en mycket liten ört, växande i uttorkadt slam, med smá hrita, rödprickiga blommor: Limosella aquatica $\mathrm{L}$.

†Ïggblomster, n.=Smörblomma. 
†̈ Äggling, $\mathrm{m}$., Liljeblad $=$ Tarald.

+ Äggplanta, f., en utländsk art af slägtet Solanum L., med stora hvita, ägglika bär: S. Melongena L.

+ Äggplommon utgår alldeles.

; Äggskål, f., Skåne = Svalört.

Ákta tillsättes vanligen hufvudarten i ett slägte, den, hvilken namnet $i$ främsta rummet tillkommer. Det Lat. officinalis öfversättes i Svenskan bäst med äkta.

† Älskling, m., ett föga passande namn på slägtet Myosotis L. 'Utgår.

$\div$ Älskogsvilla, $\mathrm{f}_{\mathrm{.}}=$ Spikklubba. Obrukligt namn.

Ältgräis, n., en mindre art af slägtet Solöga, med nedliggande stjelk, hela, lancettlika blad, mycket skarp, så att den uppdrager blåsor på huden : Rainunculus Flammula $\mathrm{x}$.

Äng., Ängs-, ett af de allmännast förekommande artnamn, t. ex. Änganis, -bulle (se Bulleblomster), -fräken, -glim, -kafle (se Kaflegräs), -salvia, -skallra (= Höskallra), -skära, -stălört, -svingel, -syra, -timjan, - vädd (= Knappvädd); Ängsgröe (= Slåttergröe), -kampe (se Kampegräs), -kovall, -lök, -näfva, -näglika, -vial m. fl. Se slägtnamnen.

Ängborst, $\mathrm{m} .=$ stagg.

Ängdun, n. (Madun, Ängull), ett slägte bland Halfgräsen, hvars mogna frukter omgifvas af lång ull : Eriopho$\dot{r} u m$ L. En art: Tufvigt Ängdun, Tufängdun ( $E$. vaginatum $\mathrm{I}$.) har särskildt flera namn i folkspråket.

Ängkrasse (Makrasse), m., ett örtslägte bland de Korsblomstrige, med krassesmak, men med långa, smala skidor, hvita blommor: Cardamine.L.

Ängkummin, m., ett åtskilliga Umbellater tillagdt, obestämdt namn; torde rättast fastställas för slägtet $C n i$ diuni косн, som eljest saknar Svenskt namn. Det utmärker sig genom fin- delade blad (dubbelt pardelade) och långa bladslidor. C. venosum Kосн.

Ängkål, m., Nerike, Upl. = sommargyllen.

Ängpipor, Ängtutor, f. pl. = Strätta.

Ängsiuta, f., ett örtslägte af Ranunkulaceernas familj, med små blommor utan kronblad och med enfröiga småfrukter: Thalictrum $\mathrm{L}$.

Äng-sticka, f., en mångårig ört af Umbellaternas familj,med lukt och gula blommor, närmande sig Libsticka, men lätt skild genom de 2-3dubbelt parbladigt delade bladen: Silaus pratensis Bess.

Ängull, f., se Ängdun.

Ãpple, Äppleträd, n., se Apel.

Irenpris, $m$., ett artrikt, till yttre utseendet mycket olikartadt slägte, tillhörande- Skeplingsväxterna, men med platt blomkrona och blott två ståndare: Veronica L. Egentligen tillkommer namnet endast Äkta Ärenprisen ( $V$. officinalis $\mathrm{L}$.), öfverallt finluden, med täta blomklasar ur de ovala bladens veck.

Axärenpris, med uppstigande stjelk och axlik blomklase i toppen: V. spicata $\mathrm{L}$.

Bäckärenpris, glatt, med aflånga blad, blomklasar i bladvecken: V. Beccabunga $\mathrm{L}$. Växer merendels i källdrag.

Strandärenpris, en med. Axärenprisen närbeslägtad art, men upprätt, högre, med 3-4 blad i krans: V. longifolia $\mathrm{L}$.

The-ärenpris, med stjelken tvåsidigt hårig, bladen hjertlika, blomklasar ur bladvecken: V. Chameedrys L. Har vackra blå blommor, hvarföre den, likasom Ögonblomman, blifvit kallad Jungfruögon.

Ärt, Ärta, f., en ettårig, allmänt odlad ört, typ för Ärtväxternas familj, med stora biblad: Pisum L. Deraf ega vi tvenne arter: 
Allmän Ärt, med flerblommiga blomskaft, hvita blommor och gulhvita frön: $P$. sativum L. Hit höra mångfaldiga artförändringar, såsom Kransärt, Sabelärt, Sockerärt,Spritärtm. $\mathrm{fl}$.

Akkerärt, med enblommiga, sällan tråblommiga blomskaft, röda blommor och spräckliga frön : $P$. arvense $\mathrm{L}$.

† Ärtbuske, m., se Kronärt.

Anm. I Dalins ordbok föres detta namn till den i södra Sverige odlade Nordamerikanska Robinia Pseud-acacia L., som dock växer upp till ett högt träd, hvilket kallas Akasieträd, men fạr ej förvexlas med slägtet Acacia. Detta träd bibehåller bäst sitt utländska namn Robinia L.

Irtskock, se Artskock.

Ärtträid, n., ett vackert träd eller buske af Ärtväxternas familj, med enblommiga blomskaft, gula blommor, trinda ärtbaljor: Caragana arborescens Lیs. Sibiriskt Ärtträd.

Irttörne, n., en mycket taggig buske, tillhörande Ärtväxterna, med stora, vackra gula blommor: Ulex europceus $\mathrm{I}$.

Ïrtväxter, en af do största och naturligaste växtfamiljer, lätt skild genom sina oregelbundna blommor, hvilka man liknat vid fjärilar (corolla papilionacea), sammanväxta stindare och baljfrukt (legumen): Papilionacece L: Leguminose Juss.

Äthäva, f., förvridning af Ethusa $=$ Glis.

Ättikros, f., en odlad art af 'Törnros: Rosa gallica $\mathrm{L}$.

Ättiksbär, n., frukten af Sommarhyll, hvilken hos våra äldste författare kallas Attig, Attik: Sambucus Ebulus 1.

Äxing, m., gräs med mer eller mindre axlik blomning. Ingår i en mängd grässlägtens namn, såsom Elfäxing, Hafreäxing, Hundäxing, Kamäxing, Tofsäxing $\mathrm{m}$. fl. - Skrifves vanligen exing, men så väl härledning (af $a x$ ) som uttal fordra $\ddot{a}$.

\section{Ö.}

† Öbär, Ölbär, n.=1) i Roslagen Odon; 2) i Dalarne Röda Vinbär.

Ögonblomma, f., ett allmänt örtslägte, tillhörande de Skrufblomstriges familj, med små blåblommor och slät frukt: Myosotis L. En art med större blommor (M. palustris Rorn) ben̈̈mnes vanligen Förgät-mig-ej.

Ögonljus, Ögonsjukegräs, n., en liten, ständigt grönskande växt, beslägtad med Vintergröna, med enblommig stjelk, stor hvit, välluktande blom$\mathrm{ma}$ : Moneses uniflora (L.) Sarrss. Användes af folket $\dot{i}$ ögonsjukdomar.

Ögontröst, f., ett ettårigt örtslägte, tillhörande Skeplingsväxterna, med spetsigt sågade blad, små, mest hvita, blåstrimmiga blommor: Euphrasia officinalis $\mathrm{L}, \mathrm{m}$. fl.

$\div$ Ölbär, se öbär.

†Ölgräs, Ölmegräs, äfven 0lmegräs, n. = Mjödört. - Namnet Ölgräs föres enligt Linné (Fl.Svec. n. 730) äfven till Renfana.

+Örnblomster, n.= Getväpling. Örnbräken, se Bräken. Örnlaf, se Laf.

† Örnträ utgâr alldeles; tillhör ej oss på minsta vis.

† Oronbild, m., svampslägtet $A u$ ricularia $F_{R}$. Förtjenar ej upptagas.

†Öronklocka, Örnaklocka(Linnés Sk. resa 319)= Liten Blåklocka. 


\section{"inte}

\section{REGISTER}

\section{öfver de Latinska växtnamnen, med hänvisning till deras Svenska benämningar.}

\section{A.}

Abies excelsa, DEc. Gran. Acacia, Nrck. Se Acacia.

- - verabica, WiLld. $\}$ Se Gummi. Acanthus, L. Se Björnklo. Acer, L. Lönn.

- campestre, 1. Nafverlönn. - Naver.

- dasycarpum, Кнкн. Luddlönn.

- platanoides, I. Svensk lönn.

- Pseudoplatanus, L. Tysk Lönn.(Sykomor.)

- saccharinum, L. Sockerlönn. Achillea Millefolium, L. Röllika. (Millefolium.) - Backhumle, Backrinka, Brygger, Brygdtuppor, Bråssor, Brässor, Bröst-tobak (se Tobak), Flengräs, (Flenört), Gantora, (Hostört), Jordhumle, Nosgräs, Näsgräs, Olsmess-umbell, Osteblomma, Pestilensblomma, Reformsört, (Renfina), Skogshumle, Snö-ört, Stengräs, Tusengren.

- Ptarmica, L. Hvit Tusenskön. Achras Supota, L. Sapotiljträd. Aconitum, L. Stormhatt.

- Cammarum, L. Blåmunk, Munkhatt, Munkmössa, Munkskalle.

- Lycoctonum, L. Nordisk Stormhatt.- Hundfloka, Lusfloka, Lusgräs, Lushatt, Lusört, Vargdöda.
Aconitum Napellus, $\mathrm{L}_{0}=$ A. Cammarum.

- septentrionale, KoELx. Lusfloka, Lusgräs.

Acorus Calamus, L. Kalmus. - Flägg. (Kalmarerot.)

Actoea spicata, L. Trolldrufva.-Hundbär, Iktebär, Ormbär, Paddbär, Trollbär, Villbär, Villdrufva:

Aḋansonia digitata, L. Apebrödsträd, Kalebasstrăd.

Adonis, L. Adonis.

- autumnalis, L. Höstadonis. Bloddroppar, Gossen i det gröna.

- vernalis, I. Våradonis. - Aronsros, Arontorpsros, Kastlöser.

Adoxa Moschatellina, L. Desmansknopp, Desmeknopp.

Ecidium, Pers. Rost. Skålrost.

- Berberidis, Prrs. Berberisrost. Egopodium Podagraria, L. Qvaller.

- Sqvaller, Sqvallerkål, Kirs, Kirskål, Trebening.

Esculus Hippocastanum, I. Hästkastanie.

Ethalium septicum, Fr. Trollsmör.

Etthusa Cynapium, L. Glis. - Glise-

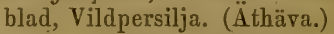

Aërides odorata, Lour. (Luftblomma.) Agaricus, $\mathrm{F}_{\mathrm{n}}$. Skifling, Skifsvamp. Skurusopp.

- campestris, L. Champignon. Puggehatt.

- esculentus, Wurf. Nagelsvamp. 
Agaricus gambosus, Fr. Hofsvamp. Musseron.

- muscarius, L. Flugsvamp.

Agave americana, L. A merikansk eller Hundraårig Aloe.

Agrimonia Eupatoria, L. Småborre.Kattrumpa, Åkermönja.

Agropyrum repens, P. BEAvv. Qrickrot. - Qvicka, Qveka, Qvekare, Qvickhvete, Qvicktåger, Hundgräs, Hundäxing, Hvitrot, Ilrot, Röte.

Agrostemma Githago, L. Klint, Rödklint._Åkerklint, Kornblomma, Kornros.

Agrostis, L. Hven.

- canina, L. Brunhren. (Hundhven).

- stolonifera, L. Kryphren. - Fioringräs.

Aira, L. Tåda. - (Tåtel.) (Smile.)

- ccespitosa, L. Tuftåda. - (Tuftåtel, Täkt-tåtel.) Bunke, Gegal, Hargräs, Tof.

- flexuosa, L. Kruståda. - (Kruståtel.) Hven, Tofhren.

Airopsis, Dess. Smile.

Ajuga, L. Blåsuga. - Käringruka (Kärinkruka, Krukört), Mjölkgubbar.

- pyramidalis, I. (Taklök, Takgran.) Alaric esculenta, (I.) Hafskål. Alcea rosea, L. Stockros.

Alchemilla Aphanes, Lerns. Jungfru Maria kam, Jungfrukam.

- vulgaris, L. Daggskål. - Daggkåpa, Duggört, Jungfru Mariæe kåpa, Kåpört, (Dragblad), Käringöron, (Lejonfot), Rynkblad, Skocka, Skåcka.

Alectoria, Acr. Trådlaf. Ståltrådslaf. Alga. Alg.

Alisma Plantago, L. Svalting. (Stäkra.) - rununculoides, L. Liten Svalting. Alkanna tinctoria, TAUsor. Se Alkanna. Alliaria officinalis, Axpnz. Hvitlöksört. Allizm, x. Lök.

- arenarium, L. Sandlök.
Allium ascalonicum, x. Chalottenlök. (Johanneslök.)

- Cepa, L. Rödlök.

- fistulosum, L. Piplök.

- oleraceum, L. Ängslök. - Hundlök.

- Porrum, L. Purjolök.

- sativum, L. Hvitlök.

- Schoenoprasum, L. Gräslök. Alvarlök, Baisk-lök.

- Scorodoprasum, L. Kejpelök, Skogslök. - Kejpe, Kep.

- ursinum, L. Ramslök. - Sankt Britæ lök.

Allosorus crispus, Вегмr. Krusbräken. Alnus glutinosa, WriLd. Al. - Grönal. - incana, $\mathrm{T}_{\text {Ausor. }}$ Arre, Ard. Gråal. - Hvital, (Ulra).

Aloë, L. Aloe.

Aloëxylon Agallochum, Lous. Indisk Aloe.

Alopecurus, L. Kaflegräs.

- geniculatus, L... Kärrkafle.

- pratensis, L. Ängkafle. - Råggräs, Räfrumpa, Räfsvans.

Alpinia Galanga, Sw. Se Galanga.

Alsinacece, $\mathrm{Fr}_{\mathrm{r} .}$ Narfväxter.

Alsine, Wa. Nörel, Nörla.

Althrea officinalis, L. Altea, Althea.Althérot, (Ibisrot).

Alyssum incanum, I. Sandhrita. (Bitterört.)

Amarantus, L. Amarant. - Tusensiön.

- Blitum, L. Bläsa. (Jfr Euxolus.)

- caudatus, L. Kalkonsnabel.

Amaryllis formosissimä, I. Amaryllis. Amelanchier canadensis, Mrs. Mrespel. Amentacere, L. Hängeväxter.

Amomum, L. Se Kardemumma.

Amygdalus communis, ... Mandelträd.

Se Mandel, Krakmandel.

- nana, L. Dvergmandel.

- persica, L. Persika, Persikoträd. Amyris gileadensis, $\mathrm{L}$. Se Meccabalsam. Anacamptis pyramidalis, Rron. Saleps-

rot, Salepsört.
Anagallis arvensis, $\mathrm{I}$. Rödarv. - A kerarv. 
Ananassa sativa, Lrswr. Ananas.

Anchusa, 1. Tungört.

- arvensis, Виев. Fårtungört. (£kerrast.)

- officinalis, L. Oxtungört, Oxtunga. - Jernrot, Jungfru Marix nyckelband, Rast.

Andrecea, Łнге. Sotmossa.

Andromeda, L. Rosling.

- polifolia, L. Allmän Rosling. (Se Andromeda.) - Svickra.

- tetragona, L. Lumkräkling, Lummerlyng.

Androsace septentrionalis, $\mathrm{L}$. Hilsko. Anemone, L. Sippa. - Låck, Låcka, Tjälablomma, Tjälatuppa, Vera, Ves m. $\mathrm{fl}$.

- Hepatica, L. Blåsippa. - Blålåcka, Killingblomma.

- hortensis, L. Se Anemon.

- nemorosa, L. Hvitsippa. - Fageblomma, Hvitlåcka, Hvitmeja.

- ranunculoides, L. Gulsippa. Smörblomster.

Anethum graveolens, L. Dill.

Angelica silvestris, 1. Strätta. - Myrstut, Slökestut, Sqvätta, Tjuton, Ängpipor, Ängtutor.

Antennaria, GrRTN. Kattfotsört, Kattfot.

- dioica, GжRтs. Kattfotsört, Kattfot. -Harfot, Hareqvä, Noppa, Pigepattar.

Anthemis, L. Kullor.

- arvensis, L. Åkerkullor. - Hvitört m. fl. (se der), Äckergräs.

- Cotula, L. Surkullor. - Hvitört m. fl., Hvitatäfva. (Baldersbrå.)

- nobilis, L. Romersk Kamomill. Se Kamillblomster.

- tinctoria, L. Letkullor, Färgkullor. - Lettblomster, Johannesblomster.

Anthericum, L. (Hvitrik.) Anthoceros, L. Lefversyl.

Anthoxanthum orloratum, L. Vårbrodd. - Amurgräs, (Lavendelgräs), Luktgräs, Majgräs.
Anthriscus, PErs. Hundkax, Hundkäxa. - Hundkummil, Rack-kummin, Spokter, Spökter, Tyde.

- Cerefolium, Horrs. (Jfr Scandix.) Svensk Körfvel.

Anthyllis, L. Väpling. (Jfr Trifolium.)

- Vulneraria, L. Getväpling. - Harväpling,(Kattklor), Räfklor, Örnblomster.

Antiaris toxicaria, Leschen. Bohon Upas.

Antirrhinum, L. Skalleblomma.

- Cymbalaria, L. (Cymbel.)

- majus, I. (Lejongap.)

- Orontium, L. Akerskalleblomma. - Kalfhufvud, Kalfnos.

Apera Spica venti, P. BEauv. Kösa. Akerhven.

Apium graveolens, L. Selleri.-(Märke.) Aquilegia vulgaris, L. Ackeleja, Akleja. - Akerleja. Tyska Klockor. Arabis, L. Backbränna.

- Thaliana, L. " - Qvesört. Arbutus Unedo, L. Se Smultronbuske. Archangelica officinalis, Horras. Qvanne. - Angelika, Engelsört, Helgeandsört, (Slöke).

Arctostaphylos alpina, Sprexid. Fjellmjölonris. - Fjellbär, Ripbär.

- Uva ursi, (七.) Mjölonris. - Mjölon, Mjölbär.

Arcyria, Hru. (Maskull.)

Areca Catechu, L. Arekapalm. - Se Betel.

- oleracea, L. Kålpalm.

Arenaria, 1. Sandnarf, Sandört.

Arenga saccharifera, LAвizL. Sockerpalm.

Aristolochia Clematitis, L. Hållsrot. Armeria, WILLD. Trift, Thrift. - Engelskt gräs, Gräsnäglika, Strandblomster.

Arnica montına, L. Hästfibla.-Horsafibla, Hästblomster, Märrblomster, Burmänner, Gullgubbar, Hårväxter, Midsommarsblomster, Sankt Hans blomster, (Nysblad), Ringblomma, Slåtterblom- 
ster, Slåttergubbar, Solsicka, (Tobaksblomma). Arnoseris pusilla, Gsnrs. Klubbfibla. Artemisia, L. Gråbo.

- Abrotanum, L. Abrodd, Åbrodd, (Ambrett).

- Absinthium, L. Malört.

- campestris, L. Fältgråbo.-Bynke.

- maritima,L.Strandgråbo.-Bynke.

- Santonica, L. Se Maskfrö.

- vulgaris, L. Allmän Gråbo. Bunrot, Buris, Bönrot, Gråböna. Artocarpus incisa, L. FiL. Brödträd. Arum maculatum, L. Munkmössa. Dansk Ingefära.

Asarum europeum, I. Hasselört. Asclepiadeœ, R. Br. Hylsväxter. Asclepias syriaca, L. Silkesört. Asparagus officinalis, L. Sparris. Aspergillus, Mrcu. Mögel. Grynhufvud. Asperugo procumbens, L. Rifva. Ormöga, Paddfot. Asperula, L. Madra.

- odorata, L. Myskemadra. Myska.

- tinctoria, L. Färgmadra.

Asphodelus, L. (Affodil.)

Aspidium, Sw. Ormbunke, Ormkagge. Asplenium, L. Bergspring. - Lånke,

Stenbryt.

- Felix femina, (L.) Majbräken.

- Ruta muraria, L. Mur-rata.

Aster, L. Aster. - (Stjernblomma.)

- chinensis, L. Stjernros. - Se Callistephrs.

- Tripolium, x. Strandkil. Astragalus boeticus, L. Se Kaffericka. - glycyphyllus, t. Backsöta. (Svensk Lakrits.) Bälarefvor. Atriplex, L. Molla.

- hortensis, I. Trädgårdsmolla.

- patula, L. Svinmolla. (Jfr Svinmell.) - Gullfrö.

- portulacoides, L. (Buskmolla.)

- rosea, L. Silfvermolla.

Atropa Belladonna, L. Belladonna.Dvalbär, Galnebär.

- Mandragora, L. Alruna.

Auricularia, Fr. (Öronbild.)
Avena, L. Hafre.

- elatior, L. Knylhafre.-Fromental. (Hafregräs.)

- fatua, L. Flyghafre. - Landhafre.

- nuda, L. Skal-lös Hafre.

- orientalis, Scurns. Turkisk Hafre.

- sutiva, L. Allmän Hafre.

- strigosa, Scunez. Purrhafre.

Azalea procumbens, L. Krepling.

\section{B.}

Bcoomyces roseus, PERs. Klubblaf. Ballota ruderalis, Sw. Bonässla. Svart-andorn.

Balsamodendron gileadense, Кчхтп. Se Balsamträd, Meccabalsam.

- Myrrha, Lrsm. Se Myrrha.

Bambusa, Sсивев. Bambu, Bamburör. Barbarea, R. Br. Sommargyllen.

- procox, R. Bz. Krassesommargyllen. - Vinterkrasse.

- vulgaris, ‥ BR. Allmänt Sommargyllen. - Ängkål.

Bartsia alpina, . Svarthö. - Bergskälla.

Batrachium, (DEc.) Grodnate. - (̊lnate.)

Batrachospermum, Roтв. Sli, Slima.

Bellis perennis, L. (den vilda) Vätteljus. - (Futteljus.)

- _ - (den odlade) Rödpyttor, Röd Tusenskön.

Berberis vulgaris, L. Surtorn. - Berberis.

Beta, L. Foderbeta, Hvitbeta, Rödbeta. Betonica officinalis, L. Humlesuga. - . Jordhumle.

Betula, L. Björk.

- alpestris, Fr. Fjellbjörk.

- nana, L. Dvergbjörk.-Fjellrapa, Fredagsbjörk, Långfredagsbjörk, Horbjörk, Källingbjörk, Myrbjörk, Klingris, Ripris, Vivang.

- odorata, Beoust. Glasbjörk, Svallbjörk. - Kartbjörk. 
Betula pubescens, Eнrн. Marbjörk. - verrucosa, Erzн. Masurbjörk. Hängbjörk, Slokbjörk.

Betulinea, Rrсн. Hängeträd, Kummerträd-(se Björk, Kummer). Jfr Amentacece.

Biatora icmadophila, $\mathrm{F}_{\mathrm{R}}$. Myrlaf.

Bidens, L. Brunskära. - Brömsar.

Bignonia, L. Se Jakaranda.

Bistorta, Tourx. (Jfi: Polygonum.) Se Ormrot.

Bixa Orellana, L. Orleanaträd.

Blechnum boreale, Sw. Kambräken.

(Kamblad.) - Björnkam. $\left.\begin{array}{c}\text { Blitum capitatum, L. } \\ \text {-virgatum, L. }\end{array}\right\}$ Sminkbär.

- virgatum, $\mathbf{L}$.

Blysmus, Paxz. Flätting.

Boletus, Drsu. Rörsopp.-(Mjölksopp.)

- bovinus, L. |Kosopp, Kosvamp.

- granulatus, L. $\}^{\text {- luteus, L. }}$ (Koticka.)

Boraginece, ADANS. Skrufblomstrige.

Borago officinalis, L. Stofferblomma. Borassus flabelliformis, L. Vinpalm. Botrychium, Sw. Låsbräken. - Låsgräs. Botrytes, Mroi. (Drufbild.)

Bovista, (L.) Bofis.

Brachypodium, P. BEAUt. Axlosta. Sparrlosta.

Brassica campestris, L. ̊kkerkål. Kålsat.

- Napoürassica, L. Kålrot. - Kålrabbi, Rotabagge.

- Napus, L. Gotlandsrofvą. - Långrofva, Spillrofva, Akerrofva. - Rofkål, Rotkål.

- - v. oleifera, Mоемсн. Rapsat.

- oleracea, L. Allmän Kål.-Blomkål, Blåkål, Hufvudkål, Hvitkål, Kruskål, Rosenkål, Savoykål.

- Rapa, L. Allmän Rofva.

Briza media, L. Darrgräs: - Bäfvegräs, Skälfvegräs. - Kärleksgräs.

Bromus, L. Losta. - Lösta, Lyxa, Löxa.

- secalinus, L. Råglosta. - Faxe, Gasse, Gåshafre, Svingel,Uäringsgräs.
Bryacece, Barrt. Bladmossor, Löfmossor.

Bryonia alba, L. Hundrofva. - Helgerefva, Qvesrot, Tyska Rofror.

Bryum, L. Rymossa.

Bulgaria, $\mathrm{Fr}_{\text {r. Limsvamp. }}$

- globosa, $\mathrm{F}_{\mathrm{R}}$. Klotlimsvamp.

- inquinans, $\mathrm{F}_{\mathrm{r}}$. Trädlimsvamp.

Bulliarda aquatica, DEc. Fyrling. Gropört.

Bunias orientalis, L. Bunias, Bunaris. - Ryssar, Ryssgubbar. (Långrofva.)

Bunium, L. (Bunjeört.)

Bupleurum tenuissimum, L. Harfloka. - (Byll.) •

Butomus umbellatus, I. Blomvass. - (Kamelblom), Säfjablomma, Vassviol, Äfjeblomma.

Buxbaumia, L. (Buxbomsmossa.)

Buxus sempervirens, I. Buxbom.

(Byssus, Мгсн. Dammossa.)

\section{C.}

Cactus, x. Cactus, Cacteer. - Se Fackeltistel.

- alatus, WirLd. Vingblomma.

- Alagelliformis, L. Rosengissel. (Paradisorm.)

- Opuntia, L. Se Indiska Fikon.

Ccesalpinia brasilien-) Se Röd Bresilja, sis, $\mathbf{L}$.

Fernbock.

- echinata, Lass. Sappan, L. Se Sappan.

Cakile maritima, Scop. Marfiol. - Vild Lackfiol. (Röd Bunias.)

Calamagrostis, Adsxs. Rör.

- arenaria, Rотн. Sandrör.-(Helm), Margräs, Marhalm, Sandhafre, Strandhafre.

- epigejos, Roxrr. Bergrör.

- silvatica, DEC. Piphven.

Calamintha, LAss. Harmynta. - Bergmynta.

- Acinos, Cuarev. Harmynta. - Hartimjan. 
Calamus Draco, Wrud. Se Drakblod.

- Rotang, x. Rottingpalm. Se Rotting, Spanskt Rör.

- Rudentum, Lour. Kabelrotting.

Calendula, L. Ringblomma. - Solsicka.

Calicium, Pers. Nubblaf.

Calla palustris, L. Missne. - Mäss.

Callistephus chinensis, Ness. Stjernros.

Callitriche, I. Lonke. - (Kälört.)

Callitris quadrivalvis, vexr. Se Sandarak.

Calluna, SALISB. (Jfr Erica.) Ljung. Ling, Lyng, Löng.

- vulgaris, SaLrss. Allmän Ljung. - Graune, Grån, Grän, Gröne, Hästljung, Horsljung,Rossljung, Rossling, Mo-ris.

Calophyllum Calaba, L. Se Calababalsam.

Caltha palustris, L. Kabbelök. - Kabbelek, Kalfleka, Krabbelök. Bäckblomma, Bäckros, Fölsungafötter, Gulalåga, Klådblomster, Skabb-blomster, Mjölkblomster, Mjölkros, Necktuppor, Påsktuppor, Smörfånga, Trimjölksgräs, Tjälablomma.

Calypso borealis, $\mathrm{S}_{\mathrm{Ax} \mathbf{r} \mathrm{s}}$. T'offelblomma. (Jfr Guckusko.)

Camelina, Craxtz. Dodra. - Dodder, Dotter m. fl.

- foetida, $\mathrm{F}_{\mathrm{R}}$. Lindodra. - Lindotter, Hörkäring.

- sativa, $\mathrm{F}_{\mathrm{R}}$. Akerdodra.

- silvestris, w SLLR. $_{\text {- Vild-dodra. }}$

Camellia, L. Se Camellia.

Campanula, L. Blåklocka. Klocka.

- glomerata, L. Toppklocka. Mosisroser.

- latifolia, L. Hässleklocka. Hässlekål. - Syssla.

- persicifolia, L. Stor Blåklocka. - Syssla.

- rapunculoides, L. Knylklocka. Rapunzel.

- Rapunculus, L. Rofklocka(Klockrofva, se Rofva). - Rapunzel.
Campanula rotundifolia, I. Allmän eller Liten Blaklocka. - Dombjälla, Märrbjälla, Fingerhatt, Skälla, Öronklocka.

- Trachelium, L. Nässleklocka. Kantklocka.

Camphora officinarum, NEES. Se Kamfert.

Cannabis sativa, L. Hampa. - Tonad. Cantharellus ribarius, $\mathrm{F}_{\text {s. }}$ Kantarell.

Capparis spinosa, I. Kaprisbuske.

Capsella Bursa pastoris, Mrv. Taskört.

- Taskegräs, (Jernört), Lomme,

Lummegräs, Nåldyna.

Capsicum annuum, L. Se Cayennpeppar.

Caragana arborescens, LAM. Ärtträd. Cardamine L. Ängkrasse, Makrasse. Braxenblomster, Bräsma, Pigesärkar, Vipestjert.

- amara, I. Bäck-krasse.

Cärdamomum, satrss. Se Kardemumma.

Carduns, L. (Jfr Cirsium.) Tistel. Stingsel.

- acanthoides, L. Piggtistel.

- acaulis, L. Jordtistel.

- arvensis, Sar. (Serratula arvensis, L.) Åkertistel. - Gortistel, Skroftistel, Stingskallar.

- crispus, L. Krustistel.

- heterophyllus, L. Borst-tistel. Borste, Brudborste, Gullborste.

- lanceolatus, L. Vägtistel.-Horntistel.

- nutans, L. Nicktistel, Sloktistel.

- palustris, L. Kärrtistel. - Vattentistel.

Carex, L. Starr. - Bunke, Fennä, Fänne, Pärr.

- acuta, L. Blåstarr.

- arenaria, L. Sandstarr. - Svensk Sarsaparill.

- caspitosa, L. Tufstarr.

- canescens, L. Gråstarr.

- ericetorum, Porr. Backstarr.

- flava, L. Knaglestarr.

- maritima, Mürz. Hafsstarr.

- pallescens, L. Blekstarr. 
Carex precox, JAcQ. Vårstarr.

- Pseudocyperus, L. Slokstarr.

- vesicaria, . Blåsestarr. - Lappskogräs, Lappskostarr, Skogräs.

- vulpina, L. Räfstarr.

Carlina, L. Stjerntistel. - Blomtistel, Spåmanstistel, (Karlintistel).

Carpinus Betulus, L. Annbok. (Afvenbok, Hagebok.) - Hvitbok. Charme. - Allon.

Carthamus tinctorius, L. Safflor.

Carum Bulbocastanum, Kосп. Jordnöt.

- Carvi, L. (Jfr Cuminum.) Kummil. - Karv, Karve, Komjan, Spiskummil.

Caryophyllus aromaticus, L. Se Kryddnäglika.

Cassandra calyculata, Dox. Andvide. Cassia, L. Kassiaträd. - Se, äfven Sennetsblad.

Castanea vesca, GsRrs. Äkta Kastanieträd, se Kastanie. - @llon.

Casuarina equisetifolia, Forss. Fräkenträd.

Catabrosa aquatica, P. BEAUv.- Narfgräs. - (Källgräs.)

Caucalis, L. (Flockört.)

Cedrus Libani, Louv. Ceder.

Celastrus, L. Se Celaster.

Centaurea, L. Knoppört.

- Cyanus, L. Klett, Blåklett, Blåklint, (Slätt). --Blågubbar, Blàhattar, Blåkorn, Blå Kornblomma, Blålilja, Blå Ringblomma, Blåtoppar, Bläört, Båtsmanshatt, Battsmansmössa, Dufstol, Kornblomma, Kornros, Akerros.

- Jacea, L. Rödklett, Gulskära, Jernört. - Färggräs, Knappar.

- Scabiosa, L. Stor Knoppört, Storhufvud. - Hårkullor, Jernrot,

Knappar, Knoppgräs, Väddklint.

Centunculus minimus, L. Knutarv, (Centunkel). Duvagräs.

Cephaëlis Ipecacuanha, Rıн. Se Ipecacuanha, Kräkrot.

Cephalanthera, Ricr. Syssla.
Cerastium, I. Hönsarv. - Hönstarmar, Nagelgräs.

Cerasus, Tounà. Körs, Körsbärsträd.

- avium, Мовмсн. Fogelkörs, Fogelbär.

- Laurocerasy Lors. Lagerkörs.

- Padus, Dec. Wagg.

- vulgaris, Mrrcs. Allmän Körs. Körsbär. Bigarrå, Morell.

Ceratonia Siliqua, L. Se Johannesbröd.

Ceratophyllum, L. Hornserf. - Flohår, (Hårört).

Cereus flagelliformis, Mrr.. Se Rosengissel.

Ceroxylon andicola, Huxrs. Vaxpalm.

Cetraria glauca, Асш. . Näfverlaf.

- islandica, A сr. Islandslaf. - Hedelaf, Hedemossa.

- juniperina, (L.) Enlaf.

- nivalis, (L.) Snölaf.

Chcerophyllum, L. Hundloka.

Chcetophora, A a. (Limblad.)

Chamcemelum inodorum, VIs. (Jfr Tripleurospermum.) Baldersbrå. Hvitört m. fl. (se der).

Chamenerion angustifolium, Scor. (Jfr Epilobium.) Kropp. - Almecke, Almocke, Almycke, Elgrams, Elgstjelk, Getstabb, Himmelsgräs, Himmelstraf, Himmelsört, (Hästsvans), Hömjölke, Imjölke, Illermjölke, (Kalfrumpa), Mjölke, Mjölkgräss, Råmjölksgräs, (Räfrumpa), Åldermjölk, Allonmärke.

Chamorchis alpina, RrcH. Ripört.

Chara, L. Sträfse. - Lavring.

Cheiranthus Cheiri, $\mathbf{~ . ~ G y l l e n l a c k . ~}$

Chelidonium majus, L. (Jfr Ficaria.)

Skelört. - (Flenört), Reformsört, Silledön, Sönnerdön.

Chenopodiacere, Dெмовт. Mollaväxter.

Chenopodium, I. Mell, Mellre.

- ambrosioides, L. Luktmolla.

- Bonus Henricus, L. Lungrot, Mjölkrot. — God Henrik, Stolt Henrik. 
Chenopodium rubrum, L. Rödmell. Jfr Sminkbär.

- urbicum, I. Bymell.

- viride, L. Svinmell. Jfr Svinmolla. - (Mjölgräs.)

- Vulvariı, L. Stinkmell. - Stäggan.

Chimaphila umbellata, Nurr. Rylört. Statt upp och gack!

Chorda Filum, (L.) Sudare, Sultråd.

Chroolepus Jolithus, Ac. Se Violsten. Chrysanthemum, $\mathbf{L}$. Krageblomma.

- Leucanthemum, I. Prestkrage, Prestkrageblomma. - Oxöga, Prestnacke, Prestskalle.

- segetum, L. Gullkrage, Gul Krageblomma. - Jfr Solsicka. - Etterört, Fattigmanstryssel, Gulleblomma, Gulört, Kornblomma, Kornros, Oxöga, Ringblomma, Skummeslöfsört.

Chrysosplenium alternifolium, L. Gullpudra. - Vif. (Jordnafle.)

Cicer avietinum, L. Kikärt. - Kaffevicka.

Cichoriacece, vaIns. Fibleväxter.

Cichorium Intybus, L. Vägvårda. Cikoria. Blå Jernört.

Cicuta virosa, L. Sprängört. - Bolmrot, Bunarot, Neckarot. - Jfr Odört.

Cinchona, L. Chinaträd (se China).

Cineraria, L. (Jfr Filago.) Nocka. (Askört.)

Cinna pendula, Trrs. Sötgräs.

Cinnamomum ceylanicum, NEEs. Kanelträd (se Kanel).

Circcea, L. Hexört. - Trollört.

Cirsium, Tourx. (Jfr Carduus.) Tistel.

Citrus Aurantium, L. Orangeträd, Pomeransträd. - Se Apelsin, Orange.

- Limonum, Rrsso. Limon.

- Medica, L. Citronträd (se Citron). Cladium Mariscus, R. Br. Ag. - $\mathrm{Am}$. Cladonia pyxidata, (I.) Bägarlaf.

- rangiferina, (L.) Renlaf, Renmossa.
Cladonice cocciferce. Coccionell-lafvar. Clathrus, Hror. Gallersvamp.

Clavaria, L. Fingersvamp. - Bockskägg.

Clematis flammula, L: (Brännört.)

Clinopodium vulgare, L. Dosta, Ringdosta. - Ringborste, Stenpoley, Vildpoley.

Cnicus benedictus, G Grex. Cardbenedikt. - oleraceus, I. Kåltistel.

Cnidium venosum, Kocr. Ängkummin. Cocculus, Dro. Se Kokelkärnar.

- palmatus, DEo. Se Kolumbo.

Coch̆learia, L. Skörbjuggsört. - Leffelkrut, Skedört.

- officinalis, L. Äkta Skörbjuggsört. Cocos butyracea, L. Fin. Smörpalm.

- nucifera, L. Kokospalm.

Coeloglossum viride, HАrтs. Grönkulla.

Coffer arabica, L. Kaffeträd.

Colchicum autumnale, L. Tidlösa. -

Nakna Jungfrun, Nakling.

Collemacea, $\mathrm{F}_{\mathrm{r}}$. Limlafvar.

Colutea arborescens, L. Blåsärt:

Comarum palustre, L. Kråk-klöfver.

- Kråkfötter, Hummeltuppor,

Kallgräs, Mjölkpungar.

Conferva Linum, L. Hafslin.

Coniferce, L. Barrträd.

Conioselinum Gmelini, Fr. Finnkarv.

Conium maculatum, L. Odört. - Jfr Sprängört.

Convallaria bifolia, L. (Smilacina, Dвsв.) Ekorrbär. - Hjertbär.

- majalis, L. Konvalje, Liljekonvalje. - Bockblad, Gliseblad, Haröra, (Hjertansfröjd), Kik i rammen, Majblomster, Majlilja, Rams (se Polygonatum).

Convolvulus I. Vinda, Vindelört.

- arvensis, L. Akervinda. - (Drabinda), Fårtarmar, Fårtunga, Jungfru Mariae särk, Käringtarmar, (Löfbinda), Snarvinda, (Snarbinda), Snarbindel.

- Batatas, L. Batatas.

- purpareus, L. Purpurvinda. Menniskolif. 
Convolvulus Scammonia, I. Se Scammonium.

- scoparius,'L. FrL. Se Rosenträd.

- sepium, L. Skogsvinda:

- tricolor, L. Dagslilja.

Coprinus, Fr. Bläcksvamp.

Corallorrhiza innata, R. Br. Korallrot. Cordyceps purpurea, Fr. (Jfr Spermoedia.) Mjöldryga. Se Honungsdagg.

(Coremium, Lisk. Luddborste.)

Coriandrum sativum, L. Koriander.

Cornus, t. Kornell.

- mascula, L. Akta Kornell.

- sanguinea, L. Röd Kornell. (Benved), Eknas, Hårdved,Struss. Galnebär.

- suecica, L. Hönsbär, Hönson. Alrot, Skrubber, Skrubbär,Smörbär, Svinbär.

Coronilla Emerus, L. Kronärt. - Ärtbuske.

Coronopus depressus, Mовмсн. Kråkkrasse. - Kråkfötter, Kråk-klor, (Hjorthorn, Hundatand).

Cortinarius, Fr. Spindelsvamp.

Corydalis, VExx. Nunneört.

- bulbosa, Pers. Fingernunneört.

- cava, (L.) Hål Nunneört. - Hålrot, Hålört.

- fabacea, Prrs. Liten Nunneört.

- nobilis, PERs. Sibirisk Nunneört. Corylus Avellana, L. Hassel, Hasselbuske. - Hässle. Lambertsnöt. Corymbiferce, Juss. Boväxter.

Corynephorus canescens, P. BEAUv. Sandborst. - Borstgräs, Borst-tåtel, (Klubbgräs).

Corypha umbraculifera, L. Parasollpalm, Solfjäderpalm.

Cotoneaster vulgaris, Lixp. Oxbärsbuske, Oxelbärsbuske. - (Mespel.)

Cotyledon, L. Se Nafvelgräs.

Cotyledonece. Hjertbladsväxter.

Crambe maritima, L. Strandkål.

Crassulacece, DEc. Fetbladsväxter.

Cratcegus, L. , Hagtorn. - Hagtornsbär, Horsabär.
Cratcegus monogyna, JAcQ. Spetshagtorn.

- Oxyacantha, L. Rund Hagtorn.

Crepis, L. Klofibla.

- biennis, L. "

— tectorum, L. " - Fälle, Åkerfälle.

Crocus, I. Saffran.

- sativus, L. Äkta Saffran.

Croton Eluteria, Sw. Se Cascarill.

- sebiferum, L. Talgträd.

- Tiglium, L. Se Crotonolja.

Cruciferce, Adaxs. Korsblomstrige.

Cryptogamce, L. Groddtrådsväxter.

Cucumis, L. Gurka.

- flexuosus, L. Slang-gurka.

- Melo, L. Melon.

- sativus, L. Allmän Gurka.

Cucurbita Lagenaria, L. Kalebass.

- Pepo, L. Pumpa. - Kurbits.

Cucurbitacea, L. Gurkväxter.

Cuminum Cyminum, L. (Jfr Carum.)

Kummin.

Cupressus sempervirens, L. Cypress.

Curcuma longa, L. Se Gurkmeja.

- Zedoaria, Roso. Se Zedoaria. Sittrer.

Cuscuta, L. Snarrefva.

- Epilinum, Wriнe. Linsnarrefva. -

Dåska, Hörsilke, Linbinda, Tobändel, Tåbengräs.

- Epithymum, (L.) (Ljungsilke.)

- major, Dxc. Allmän Snarrefva.

- Bindsleskorf, Hummelbinda,

Nässlesilke, Skorf, Pinskorf, Gult

Snärjegräs.

- Trifolii, ВАв. Klöfversnarrefva.

Cyathus, HaLL. Brödkorgsvamp.

Korgsvamp.

Cycas circinnalis, L. Se Sagogryn. Cydonia vulgaris, PERs. Qvittenträd. Cynunchum Vincetoxicum, R. BR. Tulkört. - Horskonung, Ormstingsgräs, Ormstingsrot.

Cynara Scolymus, I. Kronartskock. Cynarocephalce, Juss. Tistelväxter. Cynoglossum officinale, L. Munkfnat. - Munklöss, Prestlöss, Hundtunga, Lusgräs. 
Cynosurus cristatus, x. Kamäxing. (Kamgräs.)

Cyperacece, Juss. Halfgräs.

Cyperus esculentus, L. Jordmandel. (Mandelsäf.)

- fuscus, L. Cypergräs.

- Papyrus, L. Papyrus. (Papperssäf.)

Cypripedium Calceolus, L. Guckusko. - Jungfru Mariae sko, Lapphätta, Ormskalle, Sorgskräpp.

Cystopteris, Bегхн. Stenbräken.

Cytisus, L. Cytis.

- Laburnum, L. Gullregn. - (Bönträd.)

\section{D.}

Dactylis glomerata, $\mathrm{L}$. Hundäxing. Deedalea,' Prrs. (Jfr Trametes.) Fock. - quercina, Pers. Ekefock.

Dahlia variabilis, Dess. Dahlsros, Dahlia. - Georgin.

Daphne Mezereum, L. T'ibast, Tirsbast. — Kivelbast, Källerhals, (Lagerört), Pepparbuske.

Datura Stramonium, L. Spik-klubḅa. - Manschetter, Tisteläpple, (Älskogsvilla).

Daucus Carota, L. Morrot. - Barkenrot, Fogelbo, Gulerot.

Delphinium, L. Riddarsporre.

- Ajacis, L. Romersk Riddarsporre.

- Consolida, L. Allmän eller Vild Riddarsporre.

- Staphysagria, L. Staffansfrö.

Dentaria bulbifera, L. Tandrot. (Tandört.)

Dianthus, L. Näglika.

- arenarius, L. Sandnäglika.

-- Armeria, L. Saronsnäglika. Saronsblomster.

- barbatus, L. Borstnäglika. (Busknäglika), Studenter, Studentnäglika.

- Caryophyllus, L. Trädgårdsnäglika.
Dianthus deltoides, L. Ängsnäglika:

- plumarius, L. Fjädernäglika.

- superbus, L. Praktnäglika.

Diapensia lapponica, I. Polört.

Diatoma, DEc. (Skörsilke.)

Dicotyledonece. T'våhjertbladsväxter.

Dicranum, HEDW. Viskmossa.

Dictumnus albus, L. Nattfackla. Diptamn, Diptan.

Digilalis purpurea, L. Fingerhatt. -

Fingerborgsblomma, Finger-

borgsört, Biskopsört.

$\left.\begin{array}{c}\text { Digitaria humifusa, Pers. } \\ \text { - sanguinalis, Scop. }\end{array}\right\}$ Blodhirs.

Digraphis arundinacea, Trrx. Flen,

Flengräs. - Rörflen, Fäck, Rör-

fläck, Rörflok.

- av'undinacea v. picta, L. Randgräs.

$\left.\begin{array}{l}\text { Dioscorea alata, } \mathrm{L} . \\ \text { — sativa, L. }\end{array}\right\}$ Se Jams, Yams.

Diospyros Ebenum, L. FIr. Ebenholz.

Diplotaxis, Dec. Kålsenap.

Dipsacus, L. Kardtistel. - Kardskära. - fullonum, L. Fabrikskardtistel.

Discomycetes, $\mathrm{F}_{\mathrm{r}}$. Disksvampar.

Ditiola radicata, $\mathrm{F}_{\mathrm{R}}$. Nubbsvamp.

Draba, L. Nagelört. - Qvesört, (Sandris).

- verna, L. Rågblomma.-Snöhvita. Dracocephalum Ruyschiana L. Drakblomma. - (Blåsgom), Draknos, Märrpissegräs.

Drosera, x. Sileshăr. - Dagghår, Daggros, Daggört, Jungfru Mariae sileshår, (J. M. sänghalm), J.-M. tårar, Soldagg, Tårört, (Tätört).

Drupacea, L. Stenfruktträd.

Dryos octopetala, L. Fjellvippa.

\section{E.}

Echinochloa Crus galli, (L.) Hönshirs. - Fogelhirs.

Echinops spharocephalus, I. Bolltistel. 
Echinospermum; sw: Piggfrö.

Echium vulgare, L. Blaeld. - Blå Huggormsört, Blåkunta, Klåkunta,Blåtistel,Räfrumpa,Snokört, Vargtrut.

Ectocarpus, Lтхяв. Ylle. - Hafssilke. Eloeis guineensis, L. Oljpalm. Elaphomyces, NEEs. Haräpple. Elatine, L. Lonkeserf. - (Helting.) Eleocharis, R. Br. Knappsäf.

- palustris, R. Br. Allmän Knappsäf. - Sälta, (Sälting).

Elsholtzia cristata, WILL. Kryddmynta. Elymus arenarius, L. Strandråg. Elm, Helm, Sandelm, (Sandhafre).

Empetrum nigrum, L. Kråkris. Kräkling, Loppris. - Kråkbär, Kräkon, Skräkon.

Encalypta,'SchrEв. Ljussläckàremossa. Enodium cceruleum, PErs. Senegräs, Blått Senegräs, Sener. - (Blåslok, Blåtåtel.) Jfr Sötgräs.

Epilobium, L. Dunört.

- angustifolium, L. (Jfr Chamionerion.) Kropp.

- hirsutum, L. Luden Dunört.

Epipactis, Rхен. Zymbel.

Epipogium aphyllum, Sw. Skogsfrublomma, Snufveblomma.

Equisetum, I. Fräken, Fräkne.-Fennä, Fänne, Knarfvel, Knäckegräs, (Ledgräs).

- arvense, L. Akerfräken. - Puggerocka, Täpperocka, Räfrumpa.

- hiemale, L. Skaf-fräken. - Rone, Skafgräs, Skafrör, Skurgräs, Skäfte.

- limosum, L. Dyfräken. - Stehjok, Ströppel, Ströpple, Tärne, Algräs. - Fräkenbotten.

- palustre, L. Kärrfrạ̈ken.-Roxne.

- pratense, Eнrн. Ängbräken. Gökbet.

- silvaticum, L. Skogsfräken. Grangräs, Hästgröning, Hästsvans, Hästrumpa.

Erica, L. (Jfr Calluna.) Ljung. Eriker.
Erica Tetralix, L. Klockljung: - Kopattar.

Erigeron, L. Binka.

- acris, L. Rödbinka. - Rödbo.

Erineum, PERs. Bladgrus. - Se Gökblod.

Eriophorum, L. Ängdùn. - Hardun, Harull, Hvithufvud, Madun, Myrḍun, Myrkulla, (Ullax, Ullgräs), Ängull.

- alpinum, I. Snip. - Rumpull.

- vaginatum, $\mathbf{~ . ~ T u f v i g t ~ A ̈ n g d u n , ~}$ Tufängdun. - Hadd, Svarthufvud, Tobetel.

Erodium cicutarium, Herit. Skatnäfva. - Kammar, Kamnäfva.

Ervum, L. Lins.

- hirsutum, L. Duflins.

- Lens, L. Äkta Lins. Ảkerlins.

- tetraspermum, L. Sparflins. Musärt, Musapjask.

Eryngium maritimum, L. Manskraft. Erysimum, L. Gyllen. - (Rym.)

- cheiranthoides, L. Åkergyllen. (Åkerrym.)

- hieracifolium, L. Berggyllen.

Erysiphe, HEDw. FIL. Mjöldagg. (Jfr Honungsdagg.)

Erythræa, Rrск. Arun. - Tusengyllen, Tusendygdegräs.

Eugenia Pimenta, Dec. Se Kryddpeppar, Jamaikapeppar.

Euonymus europaeus, L. Benved. (Alster, Käringtand), Spelbom. Eupatorium cannabinum, I. Floks, (Flåckel). - Hjorttröst, (Hampört).

Euphorbia, L. Törel. - Kattpattar, Mjölkört, Silfverdyna, Tandgräs, Vărtgräs.

- antiquorum, L. Se Prustkåda.

- Helioscopia, L. Reformstörel. Reformsgräs, Reformsört, Ringormsgräs.

- officinarum, L: Se Prustkåda.

- palustris, L. Kärrtörel. - Vargmjölk, Djefvulsmjölk.

- Peplus, L. Räfmjölk. 
Euphrasia officinalis, L. Ögontröst. Ajamej.

Euxolus, RAFIN. Bläsa. Jfr Amarant. Evernia furfuracea, Fn. Klilaf.

- prunastri, Асн. Slånlaf.

- vulpina, (L.) Ulflaf, Ulfmossa.

\section{F.}

Fagopyrum esculentum, Мовмон. Bohvete, Bokhvete.

Fagus silvatica, L. Bok. Rödbok. Gjortar, Skafvel, Allon.

Falcaria Rivini, Host. Skär-floka.

Ferula Asa foetida, L. Se Dyfvelsträck. Festuca, L. Svingel. (Ax-, Manna-, Svinsvingel.)

- littorea, WG. Strandsvingel.

- ovina, L. Fårsvingel. - Fårgräs, Linnés fårgräs, Tof.

- pratensis, Huds. Ängsvingel.

Ficaria ranunculoides; Rотп. (Jfr Chelidonium.) Svalört. - (Korskåł), Kålranunkel, Möja (se Åmöja), Äggskal.

Ficus bengalensis L. Se Gummi lacca.

- carica, L. Fikonträd.

- indica, L. Se Gammi laeca.

- Sycomorus, L. Sykomor.

Filago, L. MIusört. - Harfot, Luddört, Nocka ( $F$. montana, L.).

Filices, L. Bräkenväxter.

Fistulina hepatica, Fr. Oxtungsvamp.

Fluminia arundinacea, $\mathrm{Fr}_{\mathrm{r}}$. Kase. -

Rörsvingel, Vass-svingel.

Foeniculum officinale, Arr. Fenkål.

Fontinalis antipyretica. L. Lönke.

Fragaria, I. Smultron.

- collina, kнвн. Backsmultron. Backbär, Hättebär, Nejkon, Najkon, Smällon.

— elatior, Еинн. Trädgårdssmultron, Jordgubbur.

- vesca, L. Marksmultron. - Jordbär; Rödbär, Smockbär, Snuggbär. Se Snytterbär.
Fraxinus excelsior, L. Ask. - Orne. - Ornus, L. Mannaträd.

Fritillaria, L. Kronlilja.

- imperialis, L. Kejsarkronlilja, Kejsarkrona.

- Meleagris, L. Kungskronlilja, Kungskrona: - Kungs-, Kungsängs-, Brädspels-, Damspelslilja.

Fucus, x. Tång.

- nodosus, L. Knöltång, - Buletång.

- serratus, L. Sågtång.

- vesiculosus, L. Knapptång, Klottång. - Blåstång, Hauter, Höter, Slake.

Fumaria, L. Jordrök. - Gallgräs, Åkerrök, Åkersilke (Agersilke).

Fumariacea, DEo. Kronsporreväxter.

Funaria hygrometrica, Hedw. Väderleksmossa.

Furcellaria fastigiata, Hods. Kräkel.

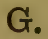

Gagec lutea, KEr. Vårlök. - Gårdlök, Kråklök, Vårfrudagslök.

Galanthus nivalis, L. Snödroppe.

Galbanum officinale, Dox. Se Galban. Galeobdolon luteum, Huds. Gulsuga.

Galeopsis, L. Dån. - Korsört. - Se Akersuga.

- versicolor, curr. Hampdån. Hampnässla, Hampört, Pipdån, Pipsör, Piptå.

Galipea officinalis, HАхооск. Se Angusturabark.

Galium, L. Måra.

- Aparine, L. Snarmåra. - Snara, Snärjegräs, Snärpegräs, (Menniskovän), Tina, Vattenbinda.

- boreale, L. Allmän Måra. - Letgräs, Letmåra.

- Mollugo, L. Hvitmåra.

- verum, L. Gulmåra. - Honungsgräs, Hviloreda (Villoreda),Jungfru Mariæe sänghalm, Klammer- 
ris, Löpegräs, Mjölkysta, Slägfrid (Sligefrö), Frillogräs, Sötört, Trätogräs.

Garcinia Cambogia, Desv. Se Gummi gutta.

Gasteromycetes, $\mathrm{F}_{\mathrm{r} .}$. Buksvampar.

Geaster, Jiron. Jordstjerna.

Genista, L. Ginst.

- germanica, L. Tagg-ginst.

- pilosa, L. Knutginst.

- tinctaria, Ł. Färgginst. - Glösen, Prengräs.

Gentiana, L. Stålört. - Gentian. Söte, Sötrot.

-- Amarella, L. Bitter Stålört, Ängstålört. - Jordgalla, Steckgräs, Steckelgräs, Stynggräs.

-- campestris, L. Allmän Stålört, Fältstålört. - Halsgräs, Hålsgräs, Steck-, Steckel-, Stynggräs, Oransört, Stickelblomma.

- lutea, L. Se Baggsöta.

- Pneumonanthe, L. Klockstålört. - Höstklocka.

- purpurea, L. Ädel eller Norsk Stålört. - Baggsöta.

Gentianeœ, Juss. Bitterväxter.

Geranium, L. Näfva, Näbb. - Storknäbb, Tranhals.

- columbinum, L. Dufvefot.

- pratense, L. Ängsnäfva. - Jansmesseblomster, Midsommarsblomster.

- Robertianum, L. Stinknäfva. Räfpiss, Vägglusgräs.

- 'sanguineum, L. Blodnäfva. Ormgräs.

- silvaticum, L. Skogsnäfva. - (Abramsrot, Bruntuppor), Gibbergräs, Morhattar, Olsmessaskopor, Olsskopor.

Gcum, I. Kummer.

- vivale, L. Fårkummer. - Brud och Brudgum, Fårpungar, Sammetspungar, Humleblomster, Kattballar.

- urbanum, L. Näglikekummer.
Gladiolus, L. Sabellilja.

Glaucium luteum, Scop. Möblomma.

Glaux maritima, L. Strandkrypa. Strandling.

Glechoma hederacea, 1.. Jordrefva. Hostört, Tusengodt.

Globularia vulgaris, L. Berg-skrabba. - Blåboll, (Klotblomma).

Glyceria aquatica, WАसцв. Kasevia, Kasevija. - Fläjegräs, (Jettegröe).

- fluitans, R. Br. Mannagräs. (Mannagröe, Mannasvingel), Gåsgräs, Svinsvingel.

- maritima, $\mathrm{W}_{\mathrm{AHLB}}$ (Sandgröe.)

Glycyrrhiza glabra, L. Lakritsört.

Gnaphalium, L. Noppa.

Goodyera repens, R. BR. Knärot.

Gossypium, L. Se Bomull.

Graminea, Juss. Gräs.

Graphis, Aсr. Skriftlaf.

Gratiola officinalis, x. Jordgalla.

Grimmia, Hedw. Raggmossa.

Guajacum officinale, L. Pockenholz, Franzosenholz.

Gymnadenia, R. Br. Brudsporie. Brudgran, Jungfru Maria brudgran.

Gypsophila, L. Såpört. - (Fänting.)

- muralis, L. (Murört.)

- Struthium, L. Se Såpört.

Gyromitra esculenta, $\mathrm{F}_{\mathrm{r}}$. Stenmurkla. Gyrophora, Acri. Nafvel-laf.

- vellea, Асн. Fäll-laf.

\section{H.}

$\left.\begin{array}{c}\text { Habzelia athiopica, DEc. } \\ \text { - aromatica, DE. }\end{array}\right\}$ Se Peppar. Ḣematoxylon campechianum, L. Kampeschträd. - Se Blå Bresilja.

Halianthus peploides, $\mathrm{F}_{\mathrm{R}}$. Saltarv. Strandportlak.

Halidrys siliquosa, LхмGв. Skolme.

Haloscias scoticum, Fr. Strandsticka.

Hebeloma, Fr. Fränskifling. 
Hetlera Helix, I. Murgrön. - Heder, Gundelref, Olivlöf, Rind, Trädvefla, Vinträd.

Hedlysarum gyrans, L. (Dansklöfver.) Helianthemum, Touns. Solvända. Helgatrefaldighetsblomster.

Helianthus, L. Solros. - Solblomma, Solkrona, Solsicka.

- tuberosus, L. Jordartskock. Jordäpple.

Helichrysum arenarium, Mовхси. Hedenblomster.

Helix, Fr. Vira.

Helleborus, L. Prustrot.

- niger, L. Srart Prustrot.

- viridis, L. Grön Prustrot.

Helosciadium inundatum, Koon. Kärrfloka. - Krypfloka.

Helxine, L. Se Binda.

Hepatica nobilis, Franak., TIIL. Se Gyllenklöfver.

Hepaticae, Juss. Lefvermossor.

Heracleum Sphondylium, L. Björnloka. - Björnfloka, Björnram, Björnstut, (Harkummil), Hundloka, Qvesgräs, Täpperot, Täpperöf. Herminium Monorchis, R.Br. Honungsblomma. - Desmansknopp.

Herniaria glabra, L. Knytling. Vägört.

Hesperis, L. Nattfiol.

- matronalis, L. Allmän Nattfiol. - Silkesblomster.

- tristis, L. Äkta Nattfiol.

Hieracium, L. Hökfibla. - Hökblomster, (Nackel, Nackblomster), Nolanaber.

Hierochloa odorata, Wa. Myskegräs. Myska, Amurgräs, Desmegräs, Jungfru Maria gräs, Luktgräs, Majgräs.

Hippomane Mancinella, ı. Manceniljträd.

Hippophaë rhamnoides, I. Haftorn. Finnbär.

Hippuris vulgaris, I. Ledgräs, Ledkrans. - Hästsvans, Hästrumpa, Räfrumpa, Vattengran.
Hirneola Auricula Judce, Benk. Judasöron.

Holcus, L. Tåtel.

- lanatus, L. Luddtâtel.

- mollis, L. Vektåtel.

- Sorghum, L. Durrha, Durrhakorn, Kafferkorn.

Holosteum umbellatum, I. Fogelarr.

Hordeum, L. Korn. - Bjugg, Bygg. Slökorn.

- distichum, x. Gumrik-korn. Gumrik, Gumring, Flätting.

- hexastichum, L. Himmelskorn. Sexradigt Korn.

- vulgare, I. Allmänt Korn. (Grofkorn.)

- Zeocriton, L. Skyffelkoru. - Plumagekorn.

Hottonin palustris, I. Blink, Vatten. blink. - Vattenröllika, Vattenviol. $\stackrel{\circ}{\text { Humulus Lupulus, L. Humle. }}$.

Hyacinthus orientalis, L. Hyacint.

Hydnum, L. Taggsvamp.

Hydrocharis Morsus ranœ, L. Dyblad. - Grodblad, Penningblad.

Hydrocotyle vulgaris, L. Spikblad. Jordnafle, Nafvelgräs, Nafvelört. Hydrodictyon, Rоти. Vattenrysja. Hygrophorus, Fn. Vaxskifling.

- subgen. Hygrocybe, $F_{\mathrm{r}}$. Saftskifling.

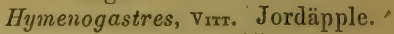

Hymenomycetes, $\mathrm{F}_{\mathrm{s}}$. Hattsvampar.

Hyoscyamus niger, $\mathrm{x}$. Bolmört. VildPalsternacka,(Hjernbrylla), Hönsbane.

Hypericum, L. Johannesknopp; Johannesört. - Johannesblomster, Jordhumle.

- perforatum, x. Äkta Johannesknopp. - Hirkenpirk, Pirkum, Mansblod.

- quadrangulum, L. Fyrkantig Johannesknopp. - Blodknopp, Mansblod.

IIypnum, x. Grenmossa. Trälmossa.

$\left.\begin{array}{l}\text { — parietinum, L. } \\ \text { — proliferum, L. }\end{array}\right\}$ Väggmossa. 
Hypochceris, I. Slåtterfibla. - Fruekål. - maculata, L. Allmän Slåtterfibla. - Gullgubbar, Slåttergubbar, Slåtterkullor.

Hyssopus officinalis, L. Isop.

\section{I.}

Iberis nudicaulis, $\mathrm{L}$. Se Iber.

Ignatia amara, L. Se Ignatii-böna.

Ilex Aquifolium, L. Krist-torn.-(Ilek.)

- paraguariensis, Sr. Hr. Se Thebuske.

Illicium anisatum, L. Sé Stjernanis.

Impatiens Balsamina, L. Balsamin.

- Noli tangere, L. Springkorn.

Imperatoria Ostruthium, L. Mästerrot. Indigofera, L. Se Indigo.

Intybus prcemorsus, FE. Fiblespira.

Inula Helenium, L. Alant. - Alunarot, Elinsrot, Helenerot, Alandsrot, Hållsrot.

- salicina, L. Kråkfötter.

Ipomoea Purga, HАxхe. Se Jalappa.

Iris, L. Svärdslilja.

- florentina, L. Se Violrot.

- Pseudacorus, L. Gul Svärdslilja.

- Bocksvärd, Bäcklilja, Bäcksvärla, Flägg, Fläje, Vattenlilja. - sibirica, ᄂ. Blå Svärdslilja.

Irpex, $\mathrm{F}_{\mathrm{r}}$. Rörtand.

Isatis tinctoria, L. Veide.

(Isidium. Korall-laf.)

Isoëtes lacustris, L. Braxengräs. Andgräs.

IsonandraGutta,Hоок. Se Gutta percha.

\section{J.}

Jacaranda, Juss. Se Jakaranda.

Jasione montana, L. Monke. - Blaknappar, Blåmonke, Munkhatt. Jasminum odoratissimum, L. Välluktande Jasmin.

Fries, Svenska växtnamnen.
Jonidium,.VEхт. Se Ipecacuanha. Juglans regia, L. Valnötsträd.

Juncus, L. Tåg.

- articulatus, L. Ryltåg. - Tjurgräs.

- bufonius, L. Kryptåg.

- conglomeratus, L. Knapptåg. Säf.

- effusus, L. Veketåg.

- filiformis, L. Trådtåg. - T'rindgräs.

- squarrosus, L. Borsttåg.

Junger'mannia, I. Snigelmossa. (Jungermansmossa.)

Juniperus communis, L. En, Enbuske. - Se Kikbär, Orkorn.

- Sabina, L. Säfvenbom.

\section{K.}

Kobresia, Wrudd. Säfstarr.

Kochia hirsuta, Nours. Luden Saltört. (Jfr Schoberia.)

Koeleria, Prrs. Tofsäxing. - (Kamgräs, Kamtåtel.)

- glauca, DEC. Blågrå Tofsäxing.

Krameria triandra, Rurz o. Paron. Se Ratanhiarot.

\section{L.}

Labiatce, Adsss. 'Sugeväxter.

Lactarius, PErs. Mjölkskifling, Mjölksopp.

- deliciosus, (L.) Riska.

- piperatus, Scop.

- turpis, $\left.\mathrm{F}_{\mathrm{R} .} \quad\right\}$ Pepparling.

- volemus, Fr. Brötling.

Lactuca, I. Laktuk.

- muralis, Dox. Skogslaktuk. Prendling.

- sativa, L. Sallatslaktuk.

- - v. capitata, L. Hufvudsallat.

- Scariola, I. Vild Laktuk.

- virosa, L. Giftig Laktuk. 
Laminaria saccharina, LАмн. Sockertång.

Lamium, L. Plister. - Se §kersuga. - album, L. Hvitplister. - (Blindnässla), Korsnäta, Pipnässla, Àkerdöer, Åkerdön.

- purpureum, L. Rödplister.

Lappa, Touns. Karborre, Kardborre. - Giktrot, Thordönsskräppa, Töflor.

Lapsana communis, L. Harkål. Tomtört.

Larix europcea, Dec. Lärkträd.-Se Venetiansk Terpentin.

Laserpitium latifolium, L. Spenört. Hjortrot, Tapsan.

Lathroea Squamaria, L: Vätteros. Fjällört, (Rylört, Liljeblads H'l. 2 uppl.)

Lathyrus, L. Vial.

- maritimus, Biger. Hafsvial. Hafsärter, Strandärter.

- odoratus, L. Luktvial, Luktärt.

- palustris, L. Kärrvial.

- pratensis, L. Ängsvial. - Gigelsärt, Gräflingshö, Vedel, Vele.

- silvestris, L. Skogsvial.

Laurus nobilis, L. Lager.

Lavandula officinalis, Craxx. Lavendel. Lavatera thuringiaca, I. Stockros. Lecanor cinerea, (L.) Gråstenslaf.

- høematomma, Aor. Blodplättlaf.

- pallescens, (L.) $\}$ Kräftstenslaf.

- Parella, (L.) K Kraftsten

- subfusca, Асr. .. Bull-laf.

- tartarea, Acr. Örnlaf. - Se Byttelet.

- ventosa, Aor. Blåslaf.

Lecidea geographica, Acr. Landkartelaf.

Ledum palustre, I. Sqvattram, Sqväckra. - Getpors, Klammer-ris, Kägrabuske,(Lummer),Villpors, Vild Rosmarin.

Leguminosce, Juss. Ärtväxter.

Lemna, L. Andmat.-Andhafre, Puggemat, Vattenlins.
Leontodon autumnalis, L. Höstfibla. Blundblomma, Mjölkblomster, Mjölkört, Smörblomma, Staduflur.

- hispidus, L. Se Höstfibla.

Leonuv'us, L. Hjertstilla, Hjertsprångsgräs. (Lejonsvans.)

$\rightarrow$ Cardiaca, L. Hjertstilla. - (Bonässla), Hampnässla, Ảsknässla, Åsknäta:

Lepidium, L. Krasse.

- cumpestre, R. Br. Fältkrasse. -Salomons ljusstake, Stillfrö.

- latifolium, L. Bitterkrasse. Bittersalsa, (Bredkrasse).

- ruderale, I. Gatkrasse. - Sokrasse, Vallkrasse.

- sativum, L. Allmän Krasse.

Lepigonum, Fr. Fjällnarf. - Nörel.

(Lepraria, Аон. Mjöl-laf.)

Lepturus, R. Br. Ormax.

Leucobryum glaucum, Haspr. Svallmossa.

Leucojum, I. Klocklilja.

- vernum, L. Snöklocka. - Vårhvita.

Levisticum officinale, Kосн. Libsticka.

Libanotis montana, Azx. Säfferot.

Lichenes pyrenocarpi. Kärnlafvar.

Ligustrum vulgare, L. Liguster. Prentebär.

Liliacece, Dec. Liljeväster. - Se Lökväxter.

Lilium, L. Lilja.

- bulbiferum, L. Brandgul Lilja.

- candidum, L. Hvit Lilja.

- Martagon, L. Kroll-lilja.

Limosella aquatica, L. Äfjebrodd. Dyplanta.

Linaria, Touns. Sporreblomma.

- vulgaris, Mrri. Flugsporreblomma. - Flugblomster, (Fluglin), Brudljus, Kalatänder, Lingräs, Linört, Solgräs.

Linncea borealis, L. Linnen, Linnésört. - Anisblomster, Jordkrona, Benvärksgräs, Giktgräs, Torrvärksgräs, Hvita Klockor, Mobjälla, Myrtåger, Skogsmysk, 
Rohaltgräs, Stighåltgräs, Vind(Vinin)gräs.

Linosyris vulgaris, DEo. Gullborste. Linum usitatissimum, I. Lin. - Hör. Knöple. Tonad.

Liriodendron tulipiferum, L. Tulpanträd.

Listera, R. BR. Tveblad.

Lithospermum, L. Stenfrö. - Glans: frö, Perlgräs.

- arvense, L. Horleta, Sminkrot.

Littorella lacustris, $x$. Strandpryl.

Lobelia Dortmanna, L. Notblomster.

Lolium, L. Repe.

- Linicola, Soxp. Linrepe.

- perenne, L. Allmänt Repe, Renrepe. - Rajgräs.

- temulentum, L. Dårrepe.-Losme, Skäde, Svemmel, Uäringsgräs, Näringsgräs, Vildpesa.

Lonicera, L. Try.

- carulea, L. Blåtry.

- Caprifolium, L. Caprifolium. Pukaris.

- Periclymenum, L. Vrivendel, Svensk Caprifolium. - Virenbom, Vrivångliträd, Käringtand, Matledsquistar, Nattfiol.

- Xylosteum, . . Allmän Try. (Benved), Hårdved, (Rosenbenved, Rosentry).

Lotus corniculatus, I. Gigelsärt. Gulhane, Göksmör, Kattklor, Käringtand.

Lunaria, L. Månfiol.

Lupinus, L. Vargböna. Lupin.

Luzula, Dec. Fryle. - Harbrodd.

Lychnis Flos cuculi, L. Gökblomma. -

Gökblomster.

Lycogala, Jrou. Gorbilla.

Lycoperdinei, Fr. Röksvampar. Blindmjöl, Blindsvamp.

Lycoperdon, Tours. Fessopp.-Käringfis, Käringrök.

Lycopodium, L. Lummer.

- annotinum, L. Reflummer.-Kalfrefvor, Refgräs, Vispmossa.
Lycopodium clavatum, L. Mattlummer. - Kalfrefvor, Mattgräs, Refgräs, Vispmossa. - Lumrik, Maskmjöl, Nicht, Pigekrut.

- complanatum, L. Jemna.

- Selago, L. Luslummer. - Loppgräs, Lusgräs.

Lycopus europaus, L. Strandklo. Vattenandorn.

Lysimachia, L. Videört.

- Nummularia, L. Penningört.

- vulgaris, L. Allmän Videört. Gullspira, (Lysblomster).

Lythrum Salicaria, L. Fackelros. - Fackelblomster; Fackelört, Strandblomster.

\section{M.}

Maclura tinctoria, Dos. Se Gelbholz, Gulholz. - Gul Bresilja.

Malachium aquaticum, $\mathrm{F}_{\mathrm{r}}$. Vattenarv. Malaxis, Sw. (Jfr Sturmia.) Myggblomma.

Malva, L. Kattost.

- Alcea, L. Rosenkattost. - Blekkattost. (Jfr Stockros.)

- borealis, WatLM. Liten Kattost.

- moschata, L. Desmekattost, Desma, Desmeros. (Jfr Stockros.)

- silvestris, x. Röd Kattost.

- vulgaris, Fr. Allmän Kattost.

Malvacece, Juss. Kattostväxter.

Manihot utilissima, Pont. Se Maniok, Tapioka.

Marante arundinacea, L. Se Arowrot. Marchantia, L. Jordlunga. (Marchantsmossa. - Elfnäfver.)

Mar'rubium vulgare, $\mathrm{L}$. Kransborre.Hvitandorn, Stjelkborre.

Matricaria Chamomilla, L. Kamillblomster, Kamillblomma.-Sötblomster, Sötkullor, Söt-tuppor, Sötört, (Gårdblomster), Hvitört o.s.v., Hvitatäfva, Kalablomster, Kommenteblomster, Lukt-tuppor, (Munkskalle). 
Matricaria inodora, $\mathbf{x}$. Se Baldersbrå. - Parthenium, L. Se Mattram. Jfr Battram.

Matthiola incana, R. Br. Löfkoja. Isackfiol. Jfr Gyllenlack.

Medicago, I. Smäre. - Käringtand.

- falcata, L. Fodersmäre, Svensk Smäre. - Kosmör, Linnés höfrö, Ljungpinnar, Rast, Refgräs.

- sativa, L. Blåsmäre. - Lucern, Luzern.

Melaleuca Leucadendrum, L. Se Cajeputolja.

-Melampyrum, L. Kovall. - Skepling.

- arvense, L. Åkerkovall. - Kohrete, Korp, Korphrete, Pukhvete, Skälle.

- cristatum, L. Korskovall. - Korsört.

- nemorosum, L. Lundkovall. Amört, Landsknektar, Svenske militärer, Natt och dag.

- pratense, L. Ängskovall. - Eksuga, Ekört, Hultasuga, Mjella, Hultamjella, Mjölkvial, Nyckelgräs, Oragräs, Orragräs, Orengräs, (Ko-, Korp-, Pukhvete).

- silvaticum, L. Skogskovall. - Ekört.

Melandrium, Rozm. Klintblära.

Melia. Azedarach, x. Se Zederack.

Melica, L. Slokgräs.

- ciliata, L. Grusslok.

- nutans, L. Bergslok.

- uniflora, Rerz. Lundslok.

Melilotus, (L.) Amur. - Melilot, Honungsklöfver, Honungsblomster, Honungsgräs.

Melissa, L. Se Hjertansfröjd.

- officinalis, L. Citronmeliss.

Menispermum Cocculus, L. Se Kokelkärnar.

Mentha, L. Mynta.

- arvensis, L. Åkermynta. - Horsamynta.

- aquatica, I. Hästmynta.

- $\quad$ - v. subsativa, $\mathrm{F}_{\mathrm{s}}$. Vild Hjertansfröjd.
Mentha crispa, I. Krusmynta.

— gentilis, I. Trädgårdismynta.

- piperita, L. Pepparmynta.

- Pulegium, I. (Poleja.)

- sativa, L. Myskmynta. - Hjertansfröjd.

- silvestris, L. Grå Mynta.

- viridis, L. Grön Mynta.

Menyanthes trifoliata, I. Bläcken. Bockblad, Getblad, Getklofving, Getklöfver, Getkål, Korsbläcker, Saltbläcker, Kråkfötter, Munkkål, Räfblad, Torskblad, Torskblomma, Vattenklöfrer, Vattenväpling.

Mercurialis perennis, $\mathrm{x}$. Bingel.

Merulius, (HАL亡.) Träfrätare.

- lacrymans, (WuLf.) Sṿamp i hus.

- Golfsvamp, Hussvamp.

Mesembryanthemum crystallinum, 'L. Isört.

Mespilus canadensis, $\mathbf{L}$.
_ germanica, L. Mespel.

Milium effusum, L. Hässlebrodd. Amurgräs, Luktgräs.

Mimosa pudica, I.) Känselblomma, - sensitiva, $\mathrm{L} . \quad\}$ Sensitiva.

Mnium, L. Stjerumossa.

Molinia, Scmraxк. Jfr Sötgräs.

Momordica Balsamina, L. Se Balsamäpple.

Moneses uniflora, (x.) SALxsB. Ögonljus, Ögonsjukegräs.

Monocotyledonece. Etthjertbladsväxter. Monotropa Hypopitys, L. Tallört. Lungört.

Montia fontana, L. Källelunk.-(Källgräs.)

Morchella esculenta, Pens. Murkla. Morus alba, L. Hvitt Mulbärsträd. - nigra, L. Svart Mulbärsträd. Mucor, Mron. Mögel. - Skimmel.

Mulgedium, Csss. Tolta. - Tort, Torta. Musa paradisiaca, L. Pisang.

- Sapientum, I. Banan, Bananas. Paradisfikon.

Muscari botryoides, Mrzz. Perldrufva. - (Drufhyacint, Perlhyacint.) 
Mrusci, L. Mossor.

Nyosotis, L. Ögonblomma. - (̈̈lsk-

ling.) Fansögon, Jungfru Mariæe ögon, Huggormsört.

- palustris, Rотн. Skön Ögonblomma, Förgät-mig-ej.

Myosurus minimus, I. Mustippa, Musrumpa.

IIyrica cerifera, L. Vaxbuske.

- Gale, L. Pors. - Skogshumle, Knagel,(Körning), Villsqvattram.

Iyricaria germanica, Desv. Klådris. Indalsris, Vild Cypress.

Myriophyllum, L. Vattenslinga. Tusenblad.

Myristica moschata, Thuмв. Muskotträd.

Iyrospermum peruiferum,| BalsamDEC.

- toluiferum, Rroн. träd.

Iyrrhis odorata, Scop. Spansk Körfvel. Mryrtus communis, I. Myrten.

\section{N.}

Najas, L. Najas, Nateserf. - (Jfr Hafshår.)

Narcissece, Juss. Narcissväxter.

Narcissus, L. Narciss.

- Jonquilla, L. Jonqvill.

- poëticus, 1. Hvit Narciss, Pingstlilja.

- Pseudonarcissus, L. Gul Narciss, Påsklilja.

- Tazetta, L. Tazett.

Nardostachys Jatamansi, DE. Nardus.

Nardus stricta, L. Stagg. - Elgborst,

Finnborst, Finnskägg, Hära, Kaffskägg, Kalfskägg,..Lapphår, Sostagg, Svinborst, Ängborst.

Narthecium ossifragum, (L.) Strandlilja. - Jfr Iglegräs, Ilagräs.

Nasturtium amphibium, k. BR. Vattensenap.

- Armoracia, $\mathrm{F}_{\mathrm{r}}$. Pepparrot.

- officinale, R. Br. Källkrasse'. Vattenkrasse.
Nasturtium silvestre, R. BR. Vattensenap.

Naumburgia thyrsiflora, (L.) REICH. Topplösa.

Nemere, Fr. Groddtrådsväxter.

Nemophila, BАRT. Kärleksblomma.

Neottia Nidus avis, (L.) Nästrot.

Nepeta Cataria, L. Kattmynta. (Näfta).

- Kattleka, Kattlusta, Lössegräs, (Nyttegräs), Tusengodt.

Nephroma arcticum, Aor. Jettelaf. Jettebröd.

Nerium Oleander, L. Se Oleander. (Rosenpil, Roslager:)

Neslia paniculata, Desv. Korndodra.

Nicotiana, L. Tobak.

- rustica, L. Bondtobak.

- Tabacum, L. Allmän Tobak.

Nigella damascena, L. Jungfrun i det gröna. Jungfrukorg.

- sativa, L. Se Svartkummin.

Nigritella angustifolia, Ricr. Brunkulla. - Brunstolar.

Nitella, Aa. Slinke, Vattenslinke.

Nostoc commune, VAU⿳亠口冋. Skyfall. Trollspy.

Nuphar luteum, Sx. Neckblad, Neckblomster. - Läblad, Lä(de)rblad, Sjöblad, Sköldblad, Vämblad. Akanna.

Nymphcea alba, L. Neckros.- Bäckblomma, Bäckros, Vattenlilja, (Vattentulpan). - Sjöållon, Akanna.

- Lotus, I. Lotusblomma.

Nymphreaceœ, Deo. Hästskoblad.

\section{O.}

Ocotea Puchury, Insr. Se Kryddböna. Octaviana variegata, Vrrx. Ekorrsvamp. Ocymum Basilicum, L. Basilik.

Odontites, PERs. Rödkulla.

Enanthe Phellandrium, Las. Stäkra. - Kaxstäkra, (Ranke).

Enothera biennis, I. Gulltraf. - (Gul Nattfiol, Gul Rapunzel.) 
Ö̈lium Tuckeri, Bars. Se Mijöldagg.

Olea europera, L. Oliv, Olivbuske, Oljoträd. -- Oleaster.

Onagrarice, Juss. Kroppräxter.

Onobrychis sativa, LAs. Helghö.

Ononis, L. Stallört.

- arvensis, L. Akerstallört. - Horsagräs, Lievarg, Ljungpinuar, Rast, (Taggpuke), Vargbasse.

- hivcina, Jیer. Stinkstallört. -

Karbas, Räfblomster.

Onopordon Acanthium, I. Tistelborre.

- Bomullstistel, (Sempertin),

Tistron.

Onygena, Pers. Hofsvamp.

Opegrapha, Аси. Skriftlaf.

Ophioglossum, L. Läketunga. - Ormskallrebräken, Ormtunga.

Ophrys Monorchis, L. Se DesmansOfris.

- Myodes, (г.) Flugblomma. (Ofris.)

Opuntia coccinellifera, DEc. Nopal.

Orchidece, $\mathbf{~}$. Nosseväxter.

Orchis, L. Nyckelblomster. - (Yxne.)

- maculata, L. Fläckigt Nrckelblomster. - Djefrulens hand, Guds hand, Herrans hand, Handknopp, Johannesnycklar, Petri nycklar, Jungfru Mariae bröst, J. M. förkläde, J. M. hand, J. M. rock.

- mascula, r. Se Salep, Spansk ryttare.

- Morio, L. Se Salep.

- ustulata, L, Svedt Nyckelblomster. - Krutbrännare.

Origanum Majorana, L. Mejram.

- vulgare, L. Konig, Koning. Frimodig, Konungsgräs, Märrmynta, (Dosta).

Ornithogalum, I. Stjernlök. - Hvita Dufvor.

- nutans, L. Aftonstjerna.

- umbellatum, L. Morgonstjerna.

Or•nithopus, L. Klovicka.

- ebracteatus, Bror. Seradella.

- perpusillus, I. Fogelklovicka.
Orobanche, I. Snyltrot.

Orobus, L. Vippärt. - (Gasse.)

- niger, L. Srart Vippärt.

- tuberosus, L. Kuylvippärt. Gubbtänder, Gölmat.

- vernus, L. Vårvippärt. - Kråkärt.

Oryza sativa, 1. Ris.

Oscillatoria, vaver. Stadun.

Osmunda regalis, L. Safjabräken. Safsabuske, Runarot.

Oxalis Acetosella, L. Harsyra. - Gülmat, Göksyra, Harväpling, Surklöfrer, Sỵrsälta, Srrsälting, Vårhane.

Oxyria digyna, (L.) Fjellsyra.

Oxytropis, Dec. Kloärt.

\section{P.}

Pceonia officinalis, Rxтz. Pion. Palma, Ausx. Palm, Palmträd.

Panax Ginseng. Se Ginseng.

Panicum miliaceum, L. Hirs.

Papaver, L. Valmo, Valmoge. - Fallblomster.

- Argemone, L. Spikvalmo.-\Åker-

- dubium, L. Akervalmo. - $\}$ silke.

- Rhoeas, L. Kornyalmo.

- somniferum, L. Äkta Valino.

Papilionacece, L. Ärtväxter.

Parietaria officinalis, L. Blidnässla. - Väggört.

Paris quadrifolia, L. Ormbär.-Fans onda bett, Hållbär, Korsört, Trollbär.

Parmelia centrifuga, (L.) Vinterlaf.

- conspersa, Aer. Pricklaf.

- olivacea, Acr. Olivlaf.

- omphalodes, Acn. Brun Letlaf. (Nafvel-laf.)

- parietina, Acr. Gull-laf. - Vägglaf.

- physodes, $\Lambda$ orr. Qveslaf.

- saxatilis, Acir. Letlaf. - Färgmossa, Letmossa, Steumossa. 
Parnassia palustris, $\mathbf{x}$. Visil; Hvit Visil. - Hjertblad, Hårnacker, Jungfru Mariae hjerta, Slåtterblomster.

Pussifor'a carulea, I. Passionsblomma. - Korsblomma, Kristi korsblomma.

Pastinaca sativa, L. Palsternacka. Paxillus involutus, I. Pluggskifling, Pluggsvamp.

Pedicularis, L. Frier._- Lusgräs. (Staf.) - palustris, L. Kärrfrier. - Jernört, Kallgräs, (Ledgräs), Gräsvarg, Lievarg, Skomakarskägg.

T Sceptrum Carolinum, Ruds., L. Kungsspira, Kung Carls spira. - Mrrkong.

- silvatica, L. Skogsfrier. - Granfrier, Grangräs, Granvarg, Granört.

Pelargonium, Henrt. Pelargonie. Jfr Geranium.

Peltiger'a, WiцLD. Sköldlaf.

- aphthosa, (L.) Torsklaf. - Elfnäfver.

Penicillium, Lixx. Mögel.

Pentadesma buty`aica, R. 13r. Smörträd. Peplis Portula, L. Rödlonke

Persea Cassia, Spr. Kasia, Kasielager.

Personatce, L. Skeplingsväxter.

Petasites frigida, $\mathrm{F}_{\mathrm{R}}$. Skråp, Skräppa.

- officinalis, Mrozмar. Pestilensrot, Pestört.

Petroselinum sativum, Hоғғs. Persilja. - Kruspersilja, Rotpersilja.

Peucedarum palustre, Mовмсш. Mossrot. - Finsk Ingefära. (Mjölkrot.)

Peziza, L. Skålsvamp. - Skålbild. Phaca frigida, L. Fjellvicka.

Phalaris canariensis, L. Kanariegräs. Phallus impudicus, L. Stinksvamp. -

Trollägg.

Phascum, L. (Jordmossa.)

Phaseolus, L. Turkisk Böna, Sabelböna. - Störböna.

- nanus, L. Krypböna.

Philadelphus coronarius, L. Schersmin. Phleum, L. Kampegräs. Kämpegräs.
Phleum phalaroides, Kогг. Flenkampe. - pratense, L. Angskampe. - Timotej.

Phoenix dactylifera, 1.. Dadelpalm. Phragmites communis, Trix. Vass, Ski1vass. - Kase, Kers, Strandrör. Phyllerium, Fr. Bladludd.

Phyllocactus phyllanthoides, Dec. Se Vingblomma.

Phyllodoce carrulea, (L.) Fjell-ljung.

Physalis Alkekengi, L. Se Judekirs.

Physcia ciliaris, $\mathrm{F}_{\mathrm{r}}$. Hårlaf.

Physostigma venenosum, Batrodr. Se

- Calabar.

Phyteuma, L. Se Rapunzel.

Picris hieracioides, $\mathrm{l}$. Bittermjölke.Snoktistel.

Pilosella, Fr. Musfibla. - Musöron, Hundfötter.

Pilularia globulifer'a, I. Furgräs. Kloting.

Pimpinella Anisum, $\mathrm{I}_{\text {.: Anis. }}$

- Saxifraga, L. Änganis. - Allbotsrot, Bockrot, Amört.

Pinguicula vulgaris, I. Tätört. - Tätgräs, Tätnacke, Fetgräs, Fetnacke, Fetört, Kråkört, Sätgräs, Sätört, Vipefett, Viṕegräs.

Pinus canadensis, L. Kanadagran, se Kanadabalsam.

- Cedrus, L. Ceder.

- Cembra, L. Se Ungersk Terpentin.

- Pinea, I. Pinie.

- silvestris, L. Fur, Fura, Tall.

Piper, L. Peppar. - Hvit-, Svart-, Lång-, Svartpeppar.

- Betle, L. Se Betel.

- Cubeba, L. ril. Se Kobeber, Kubeber.

Pistacia Lentiscus, L. Se Mastix.

- Terebinthus, L.) Se Cyprisk Ter-

- vera, L. .. $\}$ pentin.

Pisum, L. Ärt, Ärta.

— arvense, L. Akerärt.

- maritimum, L. Se Hafsvial.

- sativum, L. Allmän Ärt. - Kant-, Krans-, Kron-, Sabel-, Socker-, Spritärt. 
Plantago, I. Groblad.

- Coronopus, L. Flikigt Groblad. Kråkfötter.

- lanceolata, L. Spetsgroblad.

- major, L. Allmänt Groblad. Dragblad, Läkeblad, Läkeblacka, Vägbreda.

- muritima, L. Sutt, Suttgroblad.

- media, L. Kämpegroblad. - Kämpar, Slåsskämpar.

- Psyllium, L. Loppfrögräs, se under Loppgräs.

Platanthera, Rror. Nosserot. - Midsommarsblomster, Nattfiol; Oxgräs, Ståndpes, Ståndpers, Yxnepes.

Pleurospermum austriacum, Hоғғs. Slöke, Slökesticka.

Poa; L. Gröe.

- angustifolia, L. Slåttergröe.

- annua, L. Hvitgröe. - Gårdgräs, 'Trampgräs.

- compressa, L. Berggröe.

- nemoralis, L. Lundgröe.

- pratensis, L. Slåttergröe. Ängsgröe.

Polemonium caruleum, L. Blåljus. Blå Riddare, Blågull, Kosjuss.

Polyanthes tuberosa, L. Tuberos. Polygala, L. Jungfrulin. - Fogelört, Jungfru Mariæe hampa, hör m.fl., Mjölköka.

- Senega, L. Se Senegarot.

Polygonatum, Tours. Rams. - Bockrams, Getrams, Bockblad, Salomons sigill.

Polygonece, Juss. Slideknäväxter.

Polygonum amphibium, L. Vattenpilört.

- aviculare, L. Fogelört. - Gårdgräs, Trampgräs, (Trampnäfva), Vägört.

- Bistorta, L. Äkta Ormrot. -(Ormnäfva), Ormört.

- Convolvulus, I. Åkerbinda. Snoddergräs, Vevling, Vävling.

- dumetorim, L. Löfbinda.

- Hydropiper, L. Brännande Pilört. - Bitterblad, (Bitternäfva),
Brünna, Brudtvål, Jungfrutvål,

Loppgräs, Vattenpeppar.

Polygonum lapathifolium, L. Rockor, Ryklor.

- Persicaria, L. Mild Pilört. Rödknä, Rödknäa, (Röknäfva).

- viviparum, L. Liten Ormrot. -

Höfrö, Mortåg, Myrtåg, Svinrot. Polypodium, L. Stensöta. - Sötbräken.

- Dryopteris, I. Ekebräken. Skogslöper.

- Phegopteris, L. Hultabräken. Träjon.

- vulgare, L. Stensöta. - Bergsöta, Kariserot (Lakritsrot).

Polyporus, Fr. Ticka.

- betulinus, $\mathrm{Fr}$. Björkticka.-Korksopp, Ni̊ldyna.

- confluens, Fr. Tufrig 'Ticka, Tufticka.

- fomentarius, Fr. Fnöskticka, Fnösksvamp. - Tundersvámp.

- frondosus, Fr. Yppig Ticka.

- giganteus, Fr. Jetteticka.

- ovinus, Fr. Fårticka.

- squamosus, Fr. Fjällticka.

- sulfureus, Fr. Svafvelgul Ticka. Polysiphonia, Ag. Hafssilke.

Polytrichum commune, I. Björnmossa. - Dufråg, Guckuråg, Gökråg, Guckulin, Kråkbjugg, Kråkhvete, Kråkkorn, Sopmossa, Viskmossa, Vispmossa.

Pomacece, L. Kärnfruktträd.

Populus, L. Poppel.

- alba, L. Silfverpoppel. Hvitpoppel.

- balsamifera, I. Balsampoppel.

- nigra, L. Svartpoppel. - Poppelpil. Flugträd.

- pyramidalis, Roz. Pyramidpoppel.

- tremula, I. Asp.

Portulaca oleracea, L. Portulak.

Potamogeton, L. Nate.

- gramineus, L. Gräsnate.

- luvens, L. Grofnate.

- natans, L. Gäddnate. - Abborrnate. 
Potamogeton pectinatus, L. Borstnate. - perfoliatuss, $\mathrm{L}$. Ảlnate.

- vufescens, Scrrap. Abborrnate. - (Abborrgräs.)

Potentilla, L. Fingerört.

- anserina, L. Silfverört. - Gåsört,

(Gåsgräs), Nippramsgräs.

- argentea, L. Femfingerört, Silfverfingerört.

- fruticosa, L. Tok.

- reptans, L. Refvig Fingerört.

- Tormentilla, Nec5. Blodrot.

Rödrot, (Tormentill).

- verna, L. Vårfingerört.

Poterium Sanguisorba, ᄂ. Pimpinell. - Bibinell.

Prenanthes, $\mathrm{I}$. Se Prendling.

Primula, L. Hvifva, Vifva.

- Auricula, L. Aurikel, Aurikelhrifva. - Hanekam.

- farinosa, L. Majhvifva. - Jungfru Mariæ blomma, Lärkblomster, Majblomster, Melblomster, Svalblomster.

- veris, L, Gulhvifva, Gullhvifva.Gökblomma, Himmelsnycklar, Jungfru Maria nycklar, Nyckelblomma,Kattstöflar, Käringtand, (Majnyckel), Oxlägg, (Yrlägg), Oxlägga, Sempertuppa.

Primulacece, VENT. Hvifveväxter.

Proteacece, Juss. Silfverträd.

Prunella vulgaris, L. Brunört. Bruntuppor. - Jordhumle, Skogshumle (?), Käringrock.

Prunus, L. Slån.

- Armeniaca, L. Aprikos.

- domestica, L. Plommonträd.

- insititia, L. Krikonträd. - Tysk Slån.

- spinosa, L. Slån. - Stärkebärsbuske. Körne. - Stärkebär.

Pteris aquilina, L. Bräken, Örnbräken. - Enstabb, Enstapel, Getstabb, Ormris.

Pterocarpus Draco, L. Se Drakblod. - santalinus, L. Fiz. Se Sandelträ. Puccinia Graminis, Pens. Påfälle.
Pulicaria vulgaris, Garrv. Loppört. Brudgumpors.

Pulmonaria, L.i Lungört. Pulsatilla, Mrrz. Vippa.

- pratensis, Mrus. Fältvippa.

- vernalis, Mrr.. Movippa.-Ljungsnöre, Tjälablomma, Tjälatuppa.

- vulgaris, Mrus. Backvippa. Backsippa. - Gökskälla, Göksnöre, Oxöron.

Punica Granatum, L. Granatträd.

Pyrenomycetes, Fr. Kärnsvampar.

Pyrethrum Parthenium, ss. Battram, Berthram. Jfr Mattram.

- roseum, Bres. Se Insektpulver.

Pyrola, L. Vintergröna.

Pyrus communis, L. Päronträd. - Päron. Bergamot. Stenpäron.

- Cydonia, L. Qvittenträd.

- Malus, L. Apel, Äppleträd, (Abull). - Skogsapel: Beskapel, Surapel.-Äpple. Astrakan.Vaxäpplé.

\section{Q.}

Quassia anzara, L. Se Qvassia.

Quercus coccifer $a$, L. Se Skarlakans-ek.

- Ilex, L. Jernek, Stenek.

- Robur, L. Ek. - Akarne, §llon.

- Suber, L. Korkek, se Kork.

\section{R.}

Raconiitrium, BRID. Raggmossa.

Radiola millegranı, sị. Jordknöple.

Ramalina, Acr. Brosklaf.

Ranunculacea, Juss. Ranunkulaceer.

Ranunculus, I. Solöga. - Ranunkel.

- acris, L. Allmänt Solöga. - Gullskålar, Majblomster, Midsommarsblomster, Smörblomster, Smörört.

- arvensis, L. Åkersolöga.

- bulbosus, L. Knylsolöga. - Solhrifva, Solvisa. 
Ranunculus Flammula; L. Ältgräs. Iktegräs, Värkört. Källelunk.

- Lingua, L. Vattensolöga, Amöja.

- repens, 1. Refvigt Solöga. - Gul Tusenskön. Refgräs, Vattenrotsblomster.

- sceleratus, L. Blåseranunkel.

Raphanus, L. Rättika.

- Raphanistrum, L. Akerrättika. -

Rocka. Krampfrö.

- sativus, L. Trädgårdsrättika. -

Radis, Radisa, Rädisa.

Reseda Luteola, L. Vau.

- odorata, I. Reseda.

Rhamnus catharticus, L. Vägtorn. -

Väretorn, Vigeltorn, Virretorn,

Getapel, Getbark, Kråktorn, Krä-

ketorn, Letteträd, Ormbärsträd, Valbork.

- Frangula, L. Brake, Brakved. Tröske. - Brågon, Bråke, Bråkbuske, Gulbark, Sprakved, Svartal.

Rheum, L. Rhabarber.

- palmatum, L. Äkta Rhabarber.

- Rhaponticum, L. 'Matrhabarber.

Rhinanthus Crista galli, I. Höskallra. Ängskallra. - Göingebyxor, Hanekam, 'Tuppkam, Kattstöflar, Penninggräs, Skallergräs, Skälle.

Rhizina, Fr. Trådrotsvamp (se Trådrot).

Rhizophorece, R. Br. Se Mangroveskogar.

Rhodiola rosea, L. Rosenrot.

Rhododendron, L. Alpros. - Rosenträd.

- lapponicum, wa. Lapsk Alpros.

Rhodymenia, Grev. Söl.

Rhus Coriaria, L. Se Sumak.

- Cotinus, L. Se Fustelholz.

Rhynchospora, $\mathrm{V}_{\mathbf{A z L}}$.

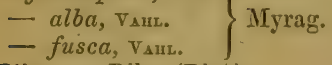

Ribes, L. Ribs, (Risp).

- alpinum, 1. Måbärsbuske. - Måbär. Degbär, Kalfbär, -Kungsbär.

- Grossularia, L. Krusbärsbuske.
Ribes nigrum, L. Svarta Vinbär. Distron, Tistron, Solbär.

- rubrum, L. Röda Vinbär. - Obär, Öbär, Ölbär.

Uva crispa, L. Stickelbärsbuske. Riccia, L. Jordstråla.

Richardsonia, Kuxrн. Se Ipecacuanha. Ricinus, L. Se Kurbits.

- communis, L. Ricin.

- Mappa, L. Duk-ricin.

Rivularia, Roти. Vattenkula.

Robinia Pseud-acacia, I. Akasieträd.

Se Ärtbuske.

Roccella, Drc. Orseljlaf. - Se Orselj.

Roestelia cornuta, Кнвн. Rönnpenselrost.

- penicillata, $\mathrm{F}_{\mathrm{r}}$. Penselrost.

Rosa, L. Nyponbuske, Törne, Törnbuske. Törnros, Trädros. - Se Kanelros, Mossros.

- canina, L. Nyponbuske. - Vinternypon. - Körne, Nypetorn. Nypon. Göpon, Juglon. - Sömntorn.

- centifolia, L. Provinsros.

- cinnamomea, L. Smörnypon.

- damascena, Arr. Månadsros.

- gallica, L. Ättikros.

- indica, L. Theros.

- mollissima, Wris. Sommarnypon.

- rubiginosa, L. Lukttörne.-Engeltorn, Neglantyr.

Rosmarinus officinalis, L. Rosmarin. - silvestris. Vild Rosmarin (Sqvattram).

Rubia tinctorum, L. Krapp.

Rubiacece, Juss. Måraväxter.

Rubus, L. Hallon.

— arcticus, L. Vikon. Akerbär. Byttbär, Jungfru .Mariæe bär.

- ccesius, L. Blåhallon. - Käringtarmar, Ljungpinnar. - Kalfhjortron, Käringbär, Käringhallon, Psalmbär, Skottlnfva.

- castoreus, 'xsss. Bäfverbär.

- Chamcemorus, L. Hjortron. - Jalbär, Molter, Multer, Snotter, Snytterbär (?). 
Rubus fruticosus, L. Björnbärsbuske. Björnbär, (Brumbär), Björnhallon.

- idceus, L. Allmän Hallonbuske. Hallon. - Bram-, Bring-, Brinn-, Brom-, Brum-, Bränn-, Fall-, Fäll-, Hind-, Hing-, Hinn-, Ullbär. A kerbär.

- plicatus, WErHE. Se under Käringbär.

- saxatilis, L. Stenhallon. - Sten- bär, Jungfru Mariæ bär, Klasbär, Kobär, Tågbär. Klason, Koddon.

- suberectus, Axders. Se under Käringbär.

Rumex, L. Syra.

- Acetosa, L. Ängsyra. - Harfot.

- Acetosella, L. Kråksyra, Bergsyra. - Svinsyra.

- crispus, I. Krussyra.-(Skräppa).

- domesticus, Hartsr. Skräppesyra. - Skräppa.

- Hippolapathum, $\mathrm{Fr}_{\mathrm{n}}$. Hästsyra. Tjerp, Tjerprot.

- Hydrolapathum, Huds. Vattensyra. Dynaskräppa.

- maritimus, L. Hafssyra.

- Patientia, I. Patientia.

Ruppia, $\mathrm{L}$. Håruate.

Ruscus aculeatus $\rightarrow \mathrm{L}$. (Mustörne.)

Russula, Fr. Kremla.

Ruta graveolens, L. Vinruta.

\section{- S.}

Saccharum officinarum, x. Sockerrör. Sagina, x. Hönsbet, Hönsgräs.

Sagittaria sagittifolia, L. Skäkteblad. Sagus Rumphii, WrLLd. Sagopalm (se Sagogryn).

Salicornia herbacea, L. Glasört. Salix, L. Pil, Pilträd, Sälg, Vide, Vira.

- acutifolia, Wris. Daggpil.

- alba, L. Hvitpil.

- amygdalina, L. Mandelpil. (Bandpil.)
Salix angustifolia, $\mathrm{r}_{\mathrm{n}}$. Marvide.

- auritix, I. Bandvide.

- babylonica, I. Sörjande Pil, Babylonisk Pil. - Tårpil.

- bicolor, Fr. Gulvide.

- caprea, L. Sälg. - Sall, Säld, Sälle.

- cinerea, L. Gråvide.

- fragilis, L. Knäckepil.

- lanceolata, Fr. Holländsk Bandpil.

- laurina, ssr. Lagervide.

- nigricans, ss. Grönvide.

- pentandra, L. Jolster, Jolsterpil. - Halster, Hilster, Hjelster, 11ster, Juster, Vekare, Vilster.

- pruinosa, Wexnl. Daggpil.

- purpurea, L. Rödvira. - Videvier.

- repens, L. Jordvide, Krypvide. Lievarg.

- rosmarinifolia, I. Rosmarinvide.

- undulata, Erri. Gul Bandpil.

- viminalis, L. Korgpil. - Tysk Bandpil. viridis, Fr. Grönpil. Salsola Kali, L. Sodaört. - (Salsel.) Salvia, L. Salvia.

- officinalis, L. .̈̈kta Salvia.

- pratensis, L. Ängsalvia.

- Sclarcea, L. (Sclarca vulgaris, Mrı..) Se Skarlakansgräs.

Sambucus, L. Hyll.

- Ebulus, L. Sommarhyll:-Mannablod, Danskablod. - Ättiksbär.

- nigra, L. Fläder, Fläderhỵll. Fulbom.

Samolus Valerandi, x. Punga.-Samosört, Samol.

Sanguisorba officinalis, L. Blodstilla; Blodtopp.

Sanicula europcea, L. Sårläka. - (Läkeört.)

Santalum album, I. Sandelträd. Sapindus Saponaria, L. Såpträd. Saponaria officinalis, L. Såpnäglika. Sarcopodium avenaceum, $\mathrm{F}_{\mathrm{R}}$. Hafrehatt.

Sargassum vulgare, AG. Se Gräshafvet. - (Hafsgräs.) 
Sassafras officinalis, NשEs. Sassafras. Satureja hortensis, I. Safver.-Kyndel. Satyrium, L. Se Satyrört.

'Saussurea alpina, DE. Fjellskära.

Saxifraga, I. Bräcka.

- Cotyledon, L. Bergbräcka.-Bergdusk.

- granulata, L. Knylbräcka.-Anisros, Hallsknoppar, Lärftsblomma, Midsommarsblomster.

- Hirculus, L. Myrbräcka.

- oppositifolia, L. Stenbräcka.

Scabiosa, L. Vädd. - Knappar.

- arvensis, L. Akervädd. - Brudgumsknappar.

- Columbaria, L. Stjernvädd. Fältvädd.

- succisa, L. Knappvädd. - Ängvädd. Blåhattar, Blåknappar, Båtsmän, (Djefvulsbett).

Scandix Cerefolium, L. Svensk Körfvel.

- Pecten, L. Nålkörfvel. — Jungfrukam.

Sceptrum Carolinum, se Pedicularis. Schedonorus, P. BEstr. Svingel-losta.

- inermis, P. BEAUv. Fodersvingellosta.

Scheuchzeria palustris, L. Kallgräs.

Schizophyllum, Fr. Klyftsvamp, se Klyfblad.

Schoberia maritima, c. A. MrEx. Glatt Saltört. (Jfr Kochia.)

Schoenus; I. Knappag.

Scilla, L. Blåstjerna. - Stjernhyacint.

- itulica, L. "

- maritima, L. Hafslök.

Scirpus, L. Säf.

- ccespitosus, L. Ramme.-Mossatof.

- lacustris, L. Sjösäf. - Kolvass.

- maritimus, L. Hafssäf.

- silvaticus, I. Skogssäf.

Scitaminece, L. Kryddliljor (se Ingefära).

Sclarcea, Mrus. Se under Skarlakansgräs.

Sclevanthus, L. Knavel. Knaflegräs. Tandgräs.
Sclerotium Semen, Toøะ. Kålfrösvamp. Scolopendrium officinarum, Sw. Mjeltbräken, (Mjeltgräs).

Scorzonera hispanica, L. Scorzonerrot. - Ringormsrot.

- humilis, t. Kornfibla. - Svinblomster, Svinrot.

Scrophularia nodosa, L. Flenört. Sodöda, Thorsnässla, T'rynefrö. Scutellaria, L. Frossört.

- galericulata, L. Allmän Frossört. - Feberört, Fredlös, Getnos.

Scytonema, AG. (Hornsilke.)

Secale cereale, $\mathrm{L}$. Råg.

Sedum, L. Fetknopp.

- acre, L. Bitterfetknopp. - Hallborre, Munkpeppar, Pallgräs, (Skörbjuggsört), Stenört.

- album, L. Hvitfetknopp. - Hälleknopp, (Hällegräs), Mörtgräs.

- annuum, L. Småknoppar.

- rupestre, L. Bergknopp. - Tripmadam.

- sexangulare, L'. Kantfetknopp. Kantknopp.

- Telephium, L. Kärleksört. - (Affodil), Bockebläcke, se Bockblad, (Huslök), Käringkål, Sankt Hans. ört; (Taklök).

Selaginella spinulosa, Au. Brsux. Smålummer.

Selinum Carvifolia, L. Krusfrö.

Sempervivum tectorum, L. Taklök. Huslök, Semperviv.

Senecio, $\mathrm{x}$. Boört.

- Jacobcea, L. Stånds. - Gullbo, Gullgro.

- vulgaris, L. Korsört. - Boört, Crucifixört, Stenört, (Blodgräs).

Senticosa, L. Brumväxter.

Servatula, L. Skära. - Själa, Själegräs, Skärda.

- arvensis, L. Akertistel. Se Carduus.

- tinctoria, L. Ängskära.

Sesamum orientale, l. Sesam.

Sesleria carulea, Ard. Elfäxing, (Elfgräs). 
Setaria, B. Brauv. Kafvelhirs.-(Kranshirs.)

Sherardia, L. Madd.

- arvensis, .... Ảkermadd. - Blåmadra.

Sibbaldia procumbens, $\mathbf{L}$. Trefingerört. Silaus pratensis, Brss. Äng-sticka.

Silenacere, Linds. Näglikeväxter.

Silene, L. Glim, Glimster.

- Armeria, L. Rödglim.

- inflata, Ssr. Tarald. - Baggpungar, Gumsepungar, Harpungar, Bläror, Dufägg, Smälla, Äggling.

- maritima, Wrrm. Tarald.

- nutans, L. Äng-glim.

- rupestris, L. Klippglim.

Silybum marianum, G ERTs. Sempertin.

- Jungfru Mariæe tistel, Marientistel.

Sinapis, L. Senap. - Simp.

- alba, I.. Hvitsenap.

- arvensis, L, Akersenap. - Gulört, Prestkål.

- nigra, I. Svartsenap.

Siphonir elastica, PErs. Se Kautschu. Sistotrema, Pers. Se Rörtand.

Sisymbrium, L. Vägsenap. - Vägkrasse.

- officinale, Scor. Allmän Vägsenap. - Dufkål, Hund-dill:

- Sophia, L. Finbladig Vägsenap. — Stillfrö.

Sium, Li. Märke.

- latifolium, L. Vattenmärke. Strätta.

- Sisarum, I. Sockermärke, Sockerrot.

Smilacina, Drsf. Se Convallaria.

Smilax China, L. Se Chinarot.

- Sarsaparilla, L. Se Sarsaparill.

Soja hispida, Мовмсн. Sojaböna.

Solanacea, Juss. Bolmväxter.

Solanum, L. Solan.

-. Dulcamara, L. Besksöta. Qvesved. - Bittersöta, Bosört, Matledsqvistar, Pukaris. - Galne-, Håll-, Orm-, Troll-; Villbär.

- Lycopersicum, 亡.: Kärleksäpple.

- - Melongena, L. Äggplanta.
Solahum nigrum, L. Nattskatta, Nattskategräs. - Hansletsbär, -gräs.

-' sodomceum, L. Sodomsäpple.

- tuberosum, I. Potates. - Jordpäron, Jordäpple, Pantoffler. Potatesblast, -kål, -ris.

Solidago, L. Gullris.

- canadensis, L. Kanada-gullris.

- Virgaurea, I. Allmänt Gullris. Gullbo, Gullgro, Jungfru Maria ris, Jungfruris, Räftunga.

Solorina crocea, Асн. Saffrans-laf.

Sonchus, L. Mjölkfibla. - (Sonke), Mjölktistel. Svintistel.

- arvensis, L. Fet Mjölkfibla, Akermjölkfibla. - Fet-tistel, Skroftistel.

- oleraceus, L. Allmän Mjölkfibla. - Vattentistel.

Sorbus, L. Oxel. Rönn.

- Aria, Craxtz. Norsk Oxel.

- Aucuparia, L. Rönn.

- fennica, KaLs. Finsk Oxél.-Oxelrönn, Suroxel.

- scandica, Fr. Svensk Oxel.

Sparganium, L.' Igelknopp. - Flä, Fläk.

- natans, L. Flotagräs. - Soppegräs.

- ramosum, Huds. Träggan. - Sparrgräs, Svärdgräs.

- simplex, Huns. Träggan.

Spartium scoparium, L. Har-ris. Spathularia, Pers. (Spadklubba.) Spergula, t. Spergel.

- arvensis, L. Akerspergel. - Fryle, Hvitglygg, Knutarv, Nägde, Pinskorf, Pjuska, Pjåsk, Spurry, Tuska.

Spermoedia Clavus, Fr. (Jfr Cordyceps.) Brandkorn. - Bockhorn, Hungerkorn, Korntagg, Mjöldryga, Mjölöka.

Sphcerobolus, Tode. Klotboll.

Sphcerophoron, PErs. Kraslafvar. (Hylslaf.)

Sphagnum, L. Hvitmossa, Rödmossa. Spigelia Anthelmia, L. Se Maskrot. 
(Spiloma. Fläcklaf.)

Spinacia oleracea, L. Spenat.

Spircea, L. Spirea.

- Filipendula, L. Brudbröd. - Galtebröd, Galteknapp, Jordgaltar, (Konvalje), Or-mylja, Somalla, Somilla, Svinbröd, Svinkrässla, Svinmandlar.

- salicifolia, L: Röd Spirea.

- Ulmaria, L. Mljödört. - Al-, Alskogs-, Bytte-, Elg-, Kall-, Lukt-, Multe-, Olme-, Ölme-, Ölgräs; Brake, Karsöta, Karört, Kassöta, Majblomster.

Splachnum lu- Bullmossa, Bullemossa. teum, 1.. - Parasollmossa, Sol-

- rubrum, skärmsmossa, JungL. $\quad \int$ fru Maria barnmössa.

Stachys, L. Syska.

- arvensis, L. Knylsyska. - Svinknyler.

- silvatica, L. Stinksyska. - (Skarlakansgräs), Stinknässla.

Stapelia, L. (Asblomma.)

Statice, L. Mar-risp. - (Stadd.)

Stellaria, L. Stjernblomma. Stjernört.

- Holostea, L. (Perer, Peror.)

- media,(L.) Nata. Vatarv, - Vannarv, Vassarv, Mire.

Stenhammaria maritima, RercH. Fjärva. - Hilsko (jfr Androsace).

Stereocaulon, Аси. Påsklaf. - Fastlagsris.

Sticta pulmonacea, Acr. Lunglaf.

Stipa, l. Borstgräs.

- pennata, L. F'jäderborstgräs. Jfr Fjädergräs.

Stratiotes aloides, L. Dyborre.-Svensk Aloe, Vattenlök, Vattensåga.

Struthiopteris germanica, Wxu. Fo-

derbräken. - Getmat, Getrofva, Strutbunke.

Strychnos, I. Se Curare.

- Nux vomica, L. Se Räfkaka.

- Tieute, Lesches. Upasträd.

Sturmia, Reror. (Jfr Malaxis.) Myggblomma.
Styrax Benzoin, Dryavp. Benzoe.

- officinalis, L. Se Storax.

Subularia aquatica, x. Sylört.

Swietenia Mahagony, L. Mahogny.

Symphytum officinale, L. Vallört. -

Benvälla, Fetrot, Svartrot.

Synantherea, Rrou. Blomhålksväxter, Hålkblomstrige.

Syringa vulgaris, x. Syren.

\section{T.}

Taberncemontana utilis, Ars. Koträd. Tagetes, I. Sammetsblomma, Sammetsros.

- erecta, L. Gul Sammetsblomma. - patula, L. Brun Sammetsblomma. Tamarix mannifer'a, Hinrexs. Tamarisk.

Tanacetum vulgare, $\tau$. Renfana. Desmegräs, Himmelskrus. - Se Maskfrö.

Taraxacum officinale, WEB. Smörblomma. - Smörblomster, Hajtand, Lejontand, Kopiss, Maskros, Mjölkblomster, Mnnkhufvud, Skallnacke, Svinros, Äggblomster.

Taxus baccata, L. Id, Idgran.,-Barrlind. Tax.

Tectona grandis, L. Tekträd.

Teesdalia nudicaulis, R. Br. Vallkrasse. Tephroseris, Rzicr. Se Nocka. Terebinthus, srozscn. Se Terpentin.

Terfezia Leonis, Tur. Se T'ryffel.

Tetragonia expansa, Arr. Nyzeeländsk Spenat.

Tetragonolobus, Scor. Klöfverärt. Sparrisärt.

- purpureus, \rosvor. Spergelklöfverärt. - Spergelärt.

-- siliquosus, Roтr. Strandklöfverärt.

Teucrium Chamcedrys, I. Gamander (jfr Löksuga).

- Scordium, L. Löksuga. - Lacklök. 
Thalictrum, L. Ängsruta.

- flavum, L. Gul Ängsruta. - Iktegräs, Torrvärksgräs.

(Thamnidium, Lxмs. Limludd.)

Thea chinensis, L. Se Thebuske.

Theobroma Cacao, L. Kakaoträd.

Thesium alpinum, L. Spindelört.

Thlaspi, L. Skärffrö. - Lomme, Lommegräs, Lummegräs.

- arvense, L. Ákerskärffrö. - Penninggräs, Skillingar, skälle, Trädeslök.

T'hymus, L. Timjan.

- Chamcedrys, Fr. Ängtimjan.

- Serpyllum, x. Backtimjan. (Svarthö.)

-- vulgaris, L. 'l'imjan.

Tilia, L. Lind. - Bastträd.

- grandifolia, Emrn. Holländsk Lind.

- parvifolia, Eнки. Skogslind.

-- vulgaris, $\mathrm{H}_{\triangle \mathrm{YNE}}$. Allé-lind.-Holländsk Lind.

Tofieldia borealis, Wa. Björnbrodd.

Tordylium, L. Se Tordyll.

Torilis Anthriscus, Grex. Rödfloka.

Tortula ruralis, Енге. Droppmossa.

Tragopogon, L. Hafrerot. - (Bockskägg), Salsofi.

- porrifolius, L. Odlad Hafrerot.

- pratensis, L. Vild Hafrerot.

Trametes, Fr. (Jfr Drdalea.) Fock.

- suaveolens, Fr. Sällefock.

Trapa natans, 1. Sjönöt: - Vattennöt.

Tr'emella, (Dirs.) Skälfving.

Auricula, L. Se Judasöron.

Trichia, Hazl. Se Maskull.

Trientalis europce, L. Dufkulla. Morkulla, Hultaviva, (Stjernros). Trifolium, L. Klöfver. (Jfr Anthyllis.) - Klofving. Jordlefver. Tusta.

- agrarium, L. Gullklöfver, Humleklöfver. - Gullkolla, Gullväpling, Jordhumle, Skogshumle(?).

- arvense, I. Harklöfver. - Harväpling, Flåsgräs, Flåsklöfver, Noppa.

- fragiferum, L. Smultronklöfver.
Trifolium hybridum, L. Alsikeklöfver. Svensk Klöfver. - Blekväpling.

- medium, (L.). Skogsklöfver. Bergklöfver.

- montanum, L. Back-klöfver. -Backväpling.

- pratense, L. Rödklöfver. - Rödfikor, -kolla, -tuppa, -tusta, -väpling; Honungsblomster, Honungsgräs.

- repens, L. Hvitklöfver. - Hvitfikor; -kolla, -räpling.

Triglochin, L. Sälting. - Saltgräs.

- maritimum, L. Strandsälting.

- palustre, L. Kärrsälting.

Triodia decumbens, P. BEAUv, Knägräs.

Tripleurospermum inodorum, Scnषuт.

(Jfr Chamøemelum.) Baldersbrå.

Trisetum, PERs. Hafreäxing.

- flavescens, P.BEAUv. Gul Hafreäxing.

Triticum, L. Hvete.

- caninum, L. Hundhrete.

- Spelta, L. Spelt.

- turgidum, L. Kubbhrete. - Sammetshvete, Skägghvete.

Trollius, L. Bulleblomster.

- asiaticus, L. Gullbulle.

- europceus; L. Ängbulle. - Dvalkullor (Hval-, Valkullor), Laxblomster, Smörbollar, Smörbullar.

Tropaolum majus, L. Skölding, Sköldört. Indiansk Krasse.

Tuber, Mroн. Tryffel. - (Jordsvamp.) - cibarium, Pers. Äkta Tryffel.

Tulipa Gesneriana, L. Tulpan.

Tunica, Scop. Saronsblomster.

Turritis glabra, $\mathrm{L}$. Rockentraf. - Karbas, (Tornört). - Stillfrö.

Tussilago Farfara, I. Hästhofsört. Bröstöri, Bröst-tobak(se'Tobak), Hostört, Fålafötter, Hästblad, Ringblomma, Tjälablomster. (Se Skråp, Skräppa.)

Typha, L. Kafveldun, Kasedun. Dunstockar, Dynaman, Kabbar, Klubbgräs, Krutläskare.

Typhacere, Sт. Hiг. Kolfväxter. 


\section{$\mathrm{U}$.}

Ulex europaus, L. Ärt-törne.

Ulmus, L. Alm.

- campestris, Sss. Korkalm.

- effusa, WirL. Vresalm.

- montana, Ss. Allmän Alm.

Ulva, L. Blacka. Bunkie.

- prunifornis, L. Sjöplommon.

Umbellate, L. Kringelväxter, Umbellatväxter.

Umbilicaria pustulata, Horfsr. Tuschlaf. Umbilicus, Dec. Jordnafle.

Urceolaria calcarea, Aсн. Kalklaf.

Uredo, PERS. Brandrost.

Urtica, L. Nässla. - Nät, Näta, Nätla.

- cannabina, L. Hampnässla.

- dioica, L. Brännässla.

- urens, L. Etternässla.

Usnea barbata, Aсн. Skägglaf. - Ragglaf.

Ustilago, Bavı. Brand. Brand i säd. Fiblebrand.

- Caries, Deg. Kolbrand.

- Segetum, Fr. Sotbrand. - Sot, Sotax.

Utricularia, L. Bläddrerot. - Vattenbläddra.

\section{W.}

Vaccinium, I. Vaksin.

- Myrtillus, I. Blåbärsris. - Blåbär. Rackbär, Slinnor, Slyngon, Slynnen.

- Oxycoccos, L. Tranbärsris.-Tranbär, Tranjuter, Tränjon, Myrbär.

- uliginosum, L. Odonbuske. - Odon, Odensbär, Blåbuk, Bäljon, Böljon, Gorvälta, Obär, Otterbär, Utterbär, Svålon, Uddbär, Vammstöt, Öbär, Ölbär.

- Vitis idœe, $x$. Lingonris. - Bremle, Krösonris. - Lingon, Lingbär, Krösa, Kröson, Kröser, Tysling, Tyttebär.
Wahlbergella, Fr. Fjellklint.

Vahlodea atropurpurea, Fi. Fjelltâtel.

Valeriana, $\mathrm{x}$. Vänderot.

- officinalis, L. Äkta Vänderot. Velamsrot, Velantsrot, Sqvättlök, Stämgräs.

Valerianea, DEc. Fläderväxter.

Valerianella, Touss. Vårsallat. - (Rapunzel.)

Vallisneria spiralis, L. Spiralört. Vanilla aromatica, Sw. Se Vanilj.

(Variolaria, Acr. Kopplaf.)

Veratrum, L. Nysrot. - Nosgräs, Näsgräs. - Prustrot.

- album, L. Hrit Nysrot. - Strandkil.

- nigrum, L. Svart Nysrot.

- Sabadilla, Rerz. Se Sabadillfrö.

Dèbascum, L. Kungsljus. - Ljusbrand, Trollslända, Trollkäringslända.

- Lychnitis, L. Hvitt Kungsljus.

- nigrum, L. Mörkt Kungsljus. Kattrumpa, Räfrumpa.

- Thapsus, L. Filtbladigt Kungsljus. - Lungört.

Verbena, L. Jernört.

Veronica, L. Ärenpris.

- agrestis, L. Akerärenpris.

- Beccabunga, L. Bäckärenpris. Bäckböna, Bäckgröna, Limmika.

- Chamcedrys, L. Theärenpris. Gamander, Jungfruögon.

- longifolia, L. Strandärenpris.

- officinalis, L. Älita Ärenpris. Jordkrypa.

- spicata, L. Axärenpris. - Kattrumpa.

- triphyllos, L. (Hönsruta.)

Verrucaria, Pers. (Vårtlaf.)

Verticillata, L. Sugeväxter.

Vetrix, Fr. Bandpil. Vide.-(Mandelpil.)

Viburnum Opulus, L. Olvonbuske. Elnaträd, lllnaträd, Snöbollsträd, Ugglerönn, Ularönn, Vattenhṛll. - Olvon, Olgon. Qvalkebär, Ugglebär, Ulfbär. 
Vicia, L. Vicka.

- Cracca, L. Kråkvicka. - Fogelvicka, Harvia, Jogere, Kråkärt.

- Faba, L. Bondböna. Hästböna.

- sativa, L. Fodervicka.

- sepium, L. Tranvicka. - Tranärt. Victoria regia, lixdu.

Vinca, L. Sinngrön. - Igrön, Ivgrön, (Vintergröna).

Viola, L. Viol.

- canina, L. Hundviol. - Länsmansstöflar.

- hirta, L. Marsviol, Buskviol.

- mirabilis, L. Underviol.

- odorata, L. Luktviol.

- silvatica, Fr. Skogsviol. - Länsmansstöflar.

- tricolor, L. Styfmorsviol. - Minnesviol. Skateblomster. Sammetsviol.

- - v. bicolor.

Viscaria, Rовнц. Tjärblomster, Tjärört.

- vulgaris, RoEнL. Allmän Tjärört.-

Beckblomster, Bekrisper, (Flugfänga).

Viscum album, L. Mistel. - Fogellim, Vespelten.
Vitis vinifera, I. Vinranka. - v. apyrena, L. Korinter. Woodsia ilvensis, R. Br. Hällebräken.

- (Woodsört.)

Xanthium, L. Gullfrö.

Xylostroma giganteum, Tode. Snufveläder. - Pukaläder.

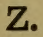

Zannichellia, L. Hårserf. - Vattenserf.

Zea Mays, L. Majs. -(TurkisktHvete.) Zingiber officinale, Roso. Se Ingefära.

Zizyphus Lotus, Lax. Lotusbuske.

- vulgaris, LAм. Se Bröstbär.

Zostera, L. Bändling. - Bandtång, Grästång, Gräsja, Hafsgräs, Sjögräs, Slånga, Haf-slånga, Tare.

Zygnema, AG. (Partrådar.) 


\section{Rättelser.}

Sid. 31, sp. 1, r. 1 står i några ex. Akervinda för Åkervinda

" 71, " $2, n 15$ " " n " $\mathrm{S}$ " $\mathrm{Så}$

"167, " 2, " 2 " " " Angskampe " Ängskampe

" 65, , 1, " 12 " Kampe för Kampegräs

" 99, " 1, , 31 "Rasta "Resta

Följande icke angifna hänvisningar äro att på sina ställen märka:
Allé-lind,
se Lind.
Bitterfetknopp, " Fetknopp.
Blåmadra,
"Madd.
Fjellbjörk,
" Björk.
Fältstålört,
Färg-ginst,
" Stålört.
Gräsnäglika,
"Ginst.
Gräsvarg,
" Trift.
Humleklöfver,
" Varg.
Hvitfetknopp,
" Klöfver.
" Fetknopp.
Hvitfikor, se Fikor.
Hvitplister, "Plister.
Hängbjörk, "Björk.
Kartbjörk, "Björk.
Klotlimsvamp, "Limsvamp.
Knutginst, "Ginst.
Knylsyska, " Syska.
Krussyra, "Syra.
Kärrtörel, "Mjölkört.
Sandelm,
" Strandråg. 
New York Botanical Garden Library 
